\title{
WestVirginiaUniversity
}

THE RESEARCH REPOSITORY @ WVU

Graduate Theses, Dissertations, and Problem Reports

2007

\section{"For men and measures" : the life and legacy of civil rights pioneer J.R. Clifford}

Connie Park Rice

Follow this and additional works at: https://researchrepository.wvu.edu/etd

Part of the African American Studies Commons, Appalachian Studies Commons, and the History

Commons

\section{Recommended Citation}

Rice, Connie Park, "'For men and measures" : the life and legacy of civil rights pioneer J.R. Clifford" (2007). Graduate Theses, Dissertations, and Problem Reports. 3953.

https://researchrepository.wvu.edu/etd/3953

This Dissertation is protected by copyright and/or related rights. It has been brought to you by the The Research Repository @ WVU with permission from the rights-holder(s). You are free to use this Dissertation in any way that is permitted by the copyright and related rights legislation that applies to your use. For other uses you must obtain permission from the rights-holder(s) directly, unless additional rights are indicated by a Creative Commons license in the record and/ or on the work itself. This Dissertation has been accepted for inclusion in WVU Graduate Theses, Dissertations, and Problem Reports collection by an authorized administrator of The Research Repository @ WVU.

For more information, please contact researchrepository@mail.wvu.edu. 
"For Men and Measures:"

The Life and Legacy of Civil Rights Pioneer

J.R. Clifford

Connie Park Rice

Dissertation submitted to the
Eberly College of Arts and Sciences
at West Virginia University
in partial fulfillment of the requirements
for the degree of

Doctor of Philosophy

In

History

Ronald L. Lewis, Ph.D., Chair

Elizabeth Fones-Wolf, Ph.D.

Kenneth Fones-Wolf, Ph.D.

Barbara Howe, Ph.D.

Joe William Trotter, Jr., Ph.D.

Department of History

Morgantown, West Virginia

2007

Keywords: J.R. Clifford, African Americans, West Virginia, Berkeley County, politics, Pioneer Press, Niagara Movement, National Independent Political League, Progressives, Black lawyers, Black editors, Martinsburg, Harpers Ferry, Jim Crow, Disfranchisement 


\section{ABSTRACT \\ “For Men and Measures:” The Life and Legacy of Civil Rights Pioneer, J.R. Clifford}

\section{Connie Park Rice}

In an era historian Rayford W. Logan described as “the nadir of black history,” African Americans confronted growing discrimination, disfranchisement, segregation, and frequent acts of violence, including lynching in the decades before and after 1900. It was an era in which a nation, and its people, violated the basic principles of American democracy. Yet despite the difficulties facing black Americans in those decades, J.R. Clifford, West Virginia's first black editor and practicing attorney, made significant strides in raising the condition and status of not only black West Virginians, but African Americans across the nation, as a result of his quest for quality black education, racial equality, and civil rights. Born into the free black family of Isaac and Mary Clifford amid the western mountains of the slave state of Virginia, Clifford rose to prominence through hard work and perseverance. Striving to improve not only himself, but the social, economic, and political status of all African Americans, Clifford frequently ignited racial, political, and class conflict that resulted in attacks on his newspaper, the Pioneer Press, as well as physical violence against his person. In 1895, Clifford became the first African-American attorney in the state to argue a case before the West Virginia State Supreme Court. In two of his appearances before the Court, Martin v. Board of Education of Paw Paw District, Morgan County and Williams v. Board of Education of Fairfax District, Tucker County, he challenged the constitutionality of West Virginia's segregated school law. In September of 1895, while Booker T. Washington was giving a speech that later became known as the “Atlanta Compromise,” J.R. Clifford stood in a courtroom in Martinsburg, West Virginia demanding the right to empanel blacks on a jury, an action that led to violence and nearly cost him his life.

At the national level, Clifford was a member of the Knights of Wise Men, the AfroAmerican Council, the American Negro Academy, the National Afro-American Press Association, the Niagara Movement, and the National Independent Political League. One of the original fifty-nine men called to attend the 1905 organizational meeting of the Niagara

Movement, a forerunner to the N.A.A.C.P., Clifford was part of the male black leadership that Du Bois' referred to as the "talented tenth." This historic meeting has often been referred to as the "birth of, or the cornerstone for, the modern civil rights movement." Clifford, and men like him, comprised a second tier of black leadership, civil rights activists who fought the battle for equal rights in their respective states and regions and provided a voice as well as support for national figureheads of the civil rights movement such as W.E.B. DuBois and Booker T. Washington and their ideologies.

His family and cultural heritage, status as a free African American, integrated education, moral and religious principles, conception of "manliness," and commitment to freedom and equality shaped the character of John Robert Clifford as a man. In turn, Clifford influenced black politics and political leaders in West Virginia from 1870 to 1933, not only through his political and legal measures, but also through his pioneer work in the field of journalism. As the first African American lawyer to practice in the state of West Virginia and one of the few black lawyers south of the Mason-Dixon Line, Clifford paved the way for the next generation of black attorneys who followed in his footsteps, men such as T.G. Nutter and Harry Capehart whose work in the West Virginia State Legislature and the N.A.A.C.P. carried on Clifford's commitment to 
civil rights. His paper, the Pioneer Press (1882-1917), quickly became a voice for African Americans from across the region and a weapon in his battle for civil rights. When it closed its doors at the end of 1917, the Pioneer Press was the longest continually running black newspaper in America.

For nearly sixty years, Clifford fought against racial injustice: from Civil War battlefields to the segregated railroad cars of the South; from rural courtrooms in the hills of West Virginia to the Presidential office of the White House; from the columns of a "modest" four-page paper called the Pioneer Press to the podiums of some of the nation's greatest lecture halls. A true civil rights pioneer, John Robert Clifford had the heart, courage, principles, and character required to change American history. 


\section{Acknowledgements}

First of all, I wish to thank my dissertation committee, not only for their contributions and support for this dissertation, but also for their encouragement, kindness, and patience throughout my graduate career. It has indeed been an honor to earn a degree in Appalachian Regional History under the direction of Dr. Ronald Lewis; his knowledge, scholarship, and mentoring has left an indelible imprint on the hearts and minds of not only his students, but on the people of this state and region as well. In thanking him, I must also thank his wife Susan who has had to endure his absences as well as his adoring students on frequent occasions. Dr. Barbara Howe has also served as a wonderful mentor, offering encouragement while instilling the desire for both the excellence and professionalism she exhibits. It was she who guided me to the path that led to J.R. Clifford. Thanks also to Dr. Elizabeth Fones-Wolf for her encouragement and the excellent teaching she continues to provide; I think I've taken every class she has ever taught and they have served me well. I would also like to thank Dr. Ken Fones-Wolf for reading the dissertation and for the invaluable observations and suggestions he provided. Last, but certainly not least, I want to thank Dr. Joe Trotter, Jr., not only for reading this dissertation, but also for his pioneer research on blacks in West Virginia. His knowledge and scholarship opened the door to future scholarship on the lives.

My research into the life and legacy of John R. Clifford provided me with the opportunity to meet members of the Clifford family, an opportunity I enjoyed and will always remember. I offer a special appreciation for those who provided much needed information for this dissertation as well as the opportunity for friendship. In particular, I would like to thank Rosemary Clifford McDaniel for sharing her research on the Clifford family genealogy, an endeavor that has taken numerous years and much hard work and continues to do so; Margaret Washington Clifford for giving me access to Clifford's extant papers as well as Paul Ingraham Clifford's unfinished manuscript on his grandfather, J.R. Clifford; Kimberly Rolls and her mother, Freda; and last, but certainly never least, J.R. Clifford's great-grand-daughter, Jennifer Neal-definitely "a chip off the old block" in every good sense of the expression.

In the process of researching and writing this dissertation I have depended on the library staff and archivists at numerous institutions; none more so than the staff at the West Virginia and Regional History Collection at West Virginia University to whom I offer a special thanks. I also give a warm thank you to a member of the library staff and my friend, Rhonda Donaldson.

During my many years at West Virginia University, I have benefited from a close circle of friends who patiently endured numerous conservations and presentations on the life and legacy of J.R. Clifford. As a group, we have prospered from the sharing of our knowledge, sources, theories, insights, suggestions, encouragement, experiences, and, most importantly, our enduring friendship. I offer a special and loving thank you to my friends and colleagues, Carletta Bush, Shirley Stewart Burns, Diane Barnes, Rebecca Bailey, and Paul Yandle.

To my family, your love and support have been invaluable. Time spent on the dissertation has frequently meant time away from you. Thank you for the patience and endurance that allowed me to follow my dream. Along the way, you have provided me with both roots and wings. I love you more than words can ever say. 
To the Spirit and Courage

of

John Robert Clifford 


\section{THE EDITOR}

Who's the most useful man in town, From preacher, lawyer, doctor down, Who neither smiles nor wears a frown? The Editor

In all the world who's most ignored, Slighted, deceived, abused and bored, And yet who's flag is never lowered?

The Editor

Who fights the battle none dare fight, For what is clearly just and right And drives the foe out of sight?

The Editor

Who lights the torch for other men, To honor, gain and wealth, and then, Who hears them say, "Do it again?"

The Editor

Who works most like a galley slave And stems the tide of wind and wave With faith and hope, and courage brave?

The Editor

Whose heavy task is never done, But meets him with each rising sun As big as when 'twas first begun?

The Editor

Who in this world shall know no rest Nor peace within his troubled breast To come a moment as his guest?

The Editor

Who'll go to heaven when he dies, And sing with angels in the skies, So very much to others surprise?

The Editor --Ex.

“The Editor,” Pioneer Press, December 5, 1914 


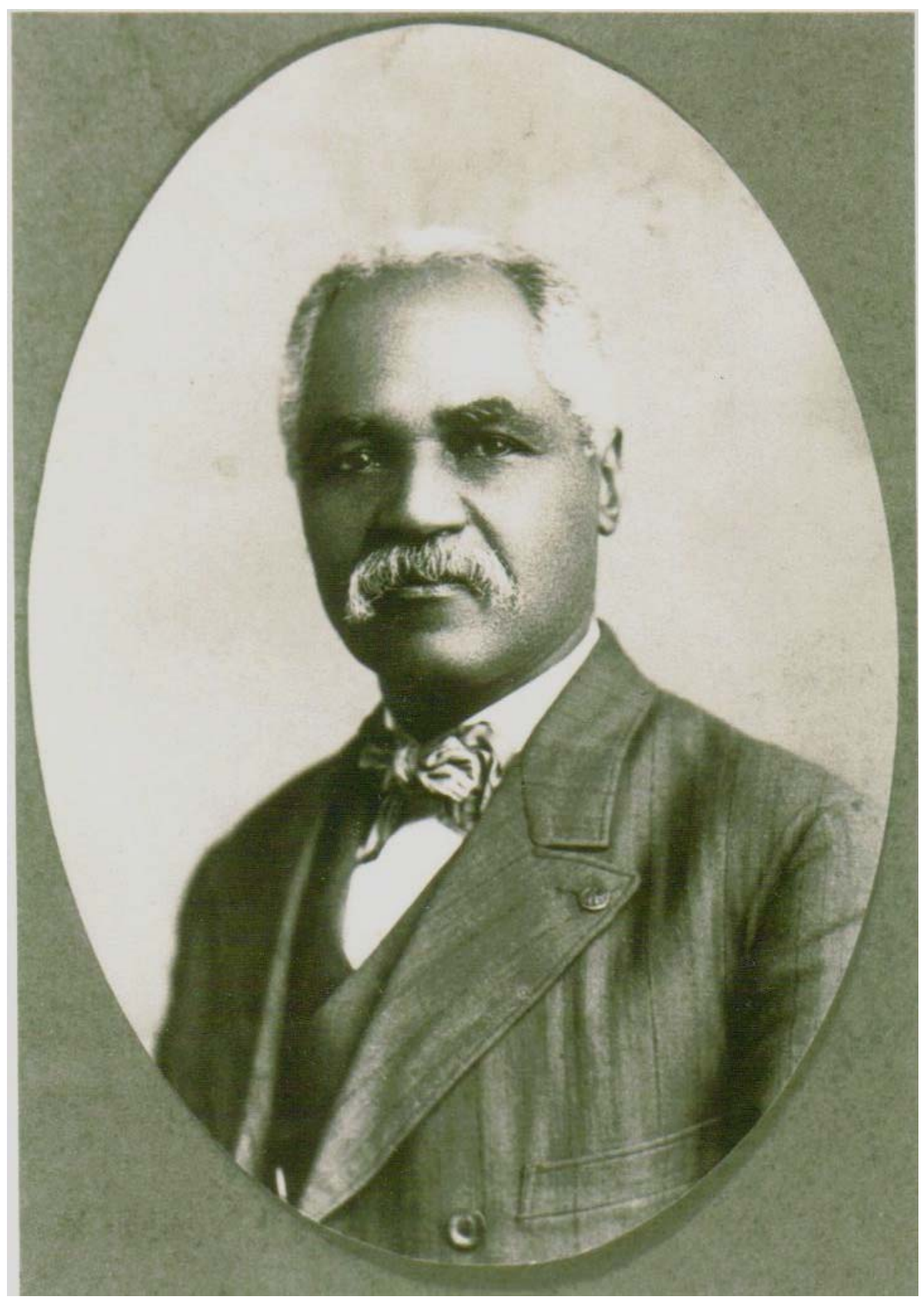

\section{J.R. CLIFFORD}

Photo courtesy of the Paul I. and Margaret Washington Clifford. Photo provided by Clifford family genealogist, Rosemary Clifford McDaniel. 


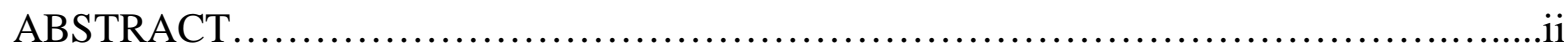

ACKNOWLEDGEMENTS...........................................................

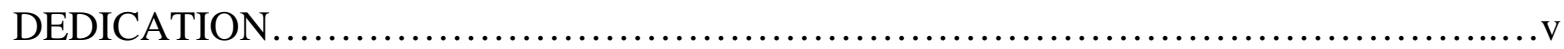

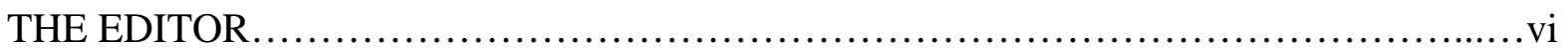

PHOTOGRAPH OF J.R. CLIFFORD ..............................................vii

TABLE OF CONTENTS............................................................iii

INTRODUCTION “WILL YOU, IF NEED BE, STAND ALONE IN THE RIGHT?”

A Civil Rights Pioneer ...........................................1

CHAPTER ONE: WITHOUT “REMORSE OR CONSCIENCE”:

Seeds of Rebellion .................................................17

CHAPTER TWO: "DOUGH-FACED, BREAD AND BUTTER POLITICIANS:"

The Road to Independence ......................................54

CHAPTER THREE: “DON’T FLINCH NOR YIELD AN INCH:”

The Struggle for Equal Rights ..................................... 85

CHAPTER FOUR: " "A MANLY BODY OF MEN:”

National Alliances and Individual Disagreements......................110

CHAPTER FIVE: “STAND UP LIKE MEN:"

Profit, Protest, and Politics.......................................147

CHAPTER SIX: A "LITTLE BARK ON THE SEA OF JOURNALISM:”

The Editor's Point of View .........................................196

CONCLUSION: "WHOLLY BY OUR CHARACTER:"

The Measure of a Man ............................................229

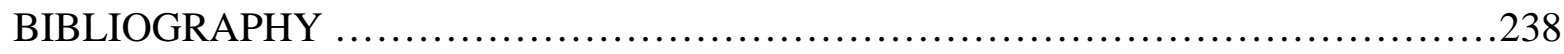

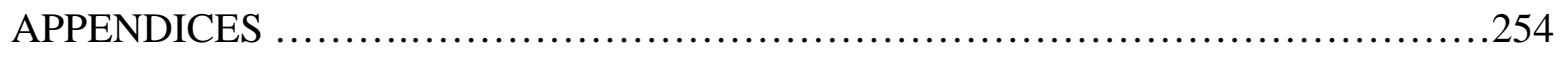




\title{
INTRODUCTION
}

\section{“WILL YOU, IF NEED BE, STAND ALONE IN THE RIGHT?” \\ A Civil Rights Pioneer}

\begin{abstract}
"The editor of the Pioneer Press wears the collar of no boss or leader. His duty lies plainly before him: it is to try to be a man; be industrious; make home and its surroundings the best he can; deal honestly with his fellow men - or to be plainer-practice the golden rule. To do any or all of these, does it require a leader? No. Do the best you can and be satisfied and the world will be satisfied with you."1
\end{abstract}

John Robert Clifford (1848-1933) was many things: bold, outspoken, stubborn or determined-depending on the point of view, principled, intelligent, and often, arrogant. Some men called him fearless, brilliant, and a "devoted race man; other men, in an attempt to denigrate him, labeled him an "infidel” or referred to him as "Cuffy."2 He was West Virginia’s first civil rights pioneer, and he became an American civil rights pioneer. Born into the free black family of Isaac and Mary Clifford amid the western mountains of the slave state of Virginia, Clifford rose to prominence through hard work and perseverance. First a farmer, then a soldier, barber, laborer, teacher, editor, and finally, an attorney, he continually strived to improve not only himself, but the social, economic, and political status of all African Americans. Frequently, his quest ignited both racial and class conflict that often resulted in attacks on his newspaper, the Pioneer Press, as well as physical violence against his person.

In an era historian Rayford W. Logan described as "the nadir of black history,” African Americans confronted growing discrimination, disfranchisement, segregation, and acts of lynching in the decades before and after 1900. It was an era in which a nation, and its people, violated the basic principles of American democracy. Years later, W.E.B. Du Bois claimed “For

\footnotetext{
${ }^{1}$ Pioneer Press, March 25, 1911.

2 “The 'Herald' Calls a Colored Man 'Cuffy,"” Martinsburg Independent, August 16, 1884; Pioneer Press, August 1885.
} 
the American Negro, the last decade of the nineteenth and the first part of the twentieth centuries were more critical than the Reconstruction years of 1868 to $1876 .{ }^{33}$ Despite the difficulties facing black Americans in those decades, J.R. Clifford made significant strides in raising the condition and status of black West Virginians as a result of his quest for quality black education and racial equality. When Clifford established the Pioneer Press in 1882, it was the first AfricanAmerican newspaper in West Virginia. Through perseverance and hardship, the Pioneer Press remained in publication for nearly thirty-six years, providing information and insight to black Americans across the nation. In 1887, after studying law with a white attorney in Martinsburg, J. Nelson Wisner, Clifford passed his bar exam, becoming the first black attorney to practice in the state of West Virginia. In 1895, Clifford became the first African-American attorney in the state to argue a case before the West Virginia State Supreme Court. In two of his appearances before the Court, Martin v. Board of Education of Paw Paw District, Morgan County and Williams v. Board of Education of Fairfax District, Tucker County, Clifford challenged the constitutionality of West Virginia's segregated school law. ${ }^{4}$

Clifford also challenged the courts of West Virginia for their failure to place blacks on juries despite the United States Supreme Court decision Strauder v. State of West Virginia giving African Americans the right and the privilege to serve as jurors. ${ }^{5}$ His persistent and determined effort to empanel blacks on a jury angered Berkeley County Prosecuting Attorney U.S.G. Pitzer, who picked up weights in the courtroom and struck Clifford over the head three times until the blood filled Clifford's shoes and he fell to the floor. In 1910, he challenged illegal and unethical

\footnotetext{
${ }^{3}$ Rayford W. Logan, The Betrayal of the Negro: From Rutherford B. Hayes to Woodrow Wilson (De Capo Press, 1997), xxi.

${ }^{4}$ William J. Simmons, “J.R. Clifford, Esq.: Editor, Lawyer, Teacher, Orator,” Men of Mark: Eminent, Progressive and Rising (Cleveland, Ohio: Geo. M. Rewell \& Co., 1887), 274-277. Available on-line at:

http://docsouth.unc.edu/neh/simmons/simmons.html.

${ }^{5}$ Men of Mark; John Reuben Sheeler, “The Negro in West Virginia Before 1900” (Ph.d. dissertation, West Virginia
} 
practices in the court system that resulted in a complaint to the United States Department of Justice and the dismissal of a United States Commissioner and a United States Marshal. In addition, between 1900 and 1916, Clifford waged continuous battle against "Jim Crow" cars. In doing so, his actions mirrored his words; Clifford refused to ride a section of the Norfolk and Western Railroad running between Shepherdstown and Charlestown, West Virginia. When he had to appear in the courtroom in Charles Town, he rode the B \& O Railroad to the Shepherdstown Junction, got off, and walked the last five miles into town. Clifford was sixtyseven years old at the time. ${ }^{6}$ After years of searching for a way to preserve the civil and legal rights of African Americans in West Virginia and the nation, Clifford joined with AfricanAmerican leaders from southern West Virginia to create the West Virginia Civic League, a precursor to the West Virginia branch of the National Association for the Advancement of Colored People (N.A.A.C.P.) ${ }^{7}$

In addition to his local commitments, Clifford participated in numerous national black organizations such as the Knights of Wise Men, the Afro-American Council, the American Negro Academy, the National Afro-American Press Association, the Niagara Movement, and the National Independent Political League. He was one of the original fifty-nine men called to attend the 1905 organizational meeting of the Niagara Movement, a forerunner to the N.A.A.C.P. Clifford remained an active member throughout the movement's existence and was an organizer for the 1906 Niagara Movement meeting held at Harpers Ferry, West Virginia. Comprised of men Du Bois' referred to as the "talented tenth," many people describe the Niagara Movement as the "birth of, or the cornerstone for, the modern civil rights movement."

Long neglected, Clifford now takes his place as a leader of the civil rights movement in

University, 1954), 203-204, 206. 
West Virginia as well as the nation. What makes Clifford unique among his contemporaries? After all, West Virginia was home to numerous well-known African Americans who could be called West Virginia's civil rights pioneer. Thomas E. Posey, a professor of economics and political science at West Virginia State College from 1926 to 1951, divided early black leadership in West Virginia into three groups in The Negro citizen of West Virginia written in 1935. Based on the years of their greatest political activity, Posey's groups consisted of a Pioneer Group (1890-1910), Middle Group (1910-1912), and a Later Group (1912-1933). Among the Pioneer Group, Posey included J.R. Clifford, Christopher Payne, Samuel Starks, James Hazelwood, Phil Waters, H.H. Railey, James M. Ellis, John Noel, J. McHenry Jones, and J. Rupert Jefferson. The only man listed in the Middle Group was Ollie Wilson. Posey’s Later Group consisted of T. Edward Hill, Matthew T. Whittico, W.W. Sanders, Harry J. Capehart, Howard E. Harper, Arthur Froe, Charles E. Mitchell, James Arthur Jackson, G.E. Ferguson, John Gilmer, J.W. Robinson, John V. Coleman, and T. G. Nutter. A prestigious group of men, each one played an important role in West Virginia history. Many of these men followed Christopher H. Payne, West Virginia’s first African-American member of the House of Delegates, into the state legislature. Samuel Starks, the first African American to serve as a State Librarian in the United States, also served as the Supreme Chancellor of the Colored Knights of Pythias of North and South America, Europe, Asia, Africa, and Australia from 1899 until his death in 1908. W.W. Sanders was West Virginia’s first African-American state school superintendent. The majority of the men Posey listed were West Virginia’s elite: lawyers, editors, and educators. ${ }^{8}$

However, Posey erred in his assessment of black political activity in the state and, in

6 Men of Mark; Pioneer Press, April 3, 1915.

7 Pioneer Press, May 22, 1915; McDowell Times, September 17, 1915.

8 Thomas E. Posey, The Negro Citizen of West Virginia (Institute, W.Va.: Press of West Virginia State College, 1935), 36-50. 
doing so, failed to include several notable early black pioneers. Black political activity in the state took place before and during the Civil War. One black West Virginian, Robert Simmons of Parkersburg, actually traveled to Washington, D.C. and visited Lincoln during the war to obtain funds for the first African-American public school south of the Mason-Dixon Line. Coming out of the war, black West Virginians participated in both Colored Border State Conventions and National Colored Conventions. ${ }^{9}$ In 1876, Simmons served as chairman at the first West Virginia Colored Convention where delegates elected four African-American men from across the state to represent them at the National Convention of Colored Men to be held in Nashville, Tennessee, under the leadership of Fredrick Douglass. That year, Simmons was also the first African American from West Virginia chosen to attend the Republican National Convention. ${ }^{10}$ The presence of a politically active black community during and immediately following the Civil War refutes not only the myth of a homogeneous white society in Appalachia, but also the myth of a region geographically isolated from the rest of the nation. Representation at these conventions indicates an earlier attempt at political organization, as well as the willingness to accept black political leadership. Clifford was aware of these state meetings and knew many of the men who attended them. As a young man, Clifford had great respect for these men and, in many ways, followed in their footsteps. Indeed, Clifford became the bridge between those who came before him and those who would follow. A Civil War veteran at the age of seventeen, by 1870 Clifford was actively engaged in politics, campaigning for his favorite Republican candidates and discussing political issues with black men such as Robert Simmons. He remained politically

\footnotetext{
${ }^{9}$ Philip S. Foner and George E. Walker, eds., Proceedings of the Black National and State Conventions, 1865-1900 (Temple University Press, 1986), 349-352, 372; Proceedings of the National Convention of the Colored Men of America,held in Washington, D.C., on January 13, 14, 15, and 16, 1869 (Washington, D.C.: Great Republic Book and Newspaper Printing Establishment, 1869), 6. Schomburg Center for Research in Black Culture, New York Public Library, New York, New York.

${ }^{10}$ Pioneer Press, September 1886; “Proceedings of Tuesday’s Convention of West Virginia Colored Men,” Wheeling
} 
active, a constant influence on the next generation of lawyers and political activists, until his death in 1933. During those years, he attacked injustice in the pages of the Pioneer Press and made permanent changes to the state’s legal system in his quest for civil rights. It was not an easy task, for between 1870 and 1933 over thirty lynchings took place in the state of West Virginia and, in one horrifying case, whites skinned a black man alive. ${ }^{11}$

Clifford influenced all black politics and political leaders in West Virginia from 1870 to 1933, not only through his political and legal measures, but also through his pioneer work in the field of journalism. When the Pioneer Press closed its doors at the end of 1917, it was the longest continually running black newspaper in America. During that time, over twenty-six African-American newspapers opened and closed in West Virginia; most had a life span of one to five years. Clifford's enemies made numerous attempts to shut the newspaper down, but never could.

Clifford clearly stands out among the state’s black leaders. More significantly, Clifford stands out among nationally prominent African Americans who called West Virginia home. Among Clifford's contemporaries, this includes such men as Martin Delany, the "father of Black Nationalism,” Booker T. Washington, America’s pre-eminent black leader following the death of Fredrick Douglass in 1895, Carter G. Woodson, the "father of African-American” history, Mordecai Johnson, the first African-American president of Howard University, and John W. Davis, president of West Virginia State College and, later on, Director of the N.A.A.C.P.'s Legal Defense and Education Fund. All of these men participated in national politics, joined national organizations, and were willing to take a stand for their beliefs. Yet none of these men, except John Robert Clifford, remained in West Virginia. Despite strong national ties and a radical stance

Daily Intelligencer, March 9, 1876; and Keyser West Virginia Tribune, May 20, 1876. 
that alienated him from the majority of black West Virginians, Clifford chose to remain. In 1912, Clifford wrote:

“The editor of this paper thinks more of his home, and the place of his nativity than any other place on God's green earth, and when it comes to politics, he thinks more of how his state should go, than who the president should be. We are not afraid of the democrats of this state, from the fact, there are not enough ring-tailed devils among them to do us harm, and our advice is: vote for real men, rather than for party men, and in doing so make those you support pledge their honor to stand by your constitutional rights."12

Clifford was more than willing to stay in a state south of the Mason-Dixon Line and fight for what he wanted, and he had no intention of compromising.

Indeed, for many African Americans across the nation, the end of Reconstruction brought disappointment and disillusionment with the Republican Party. ${ }^{13}$ Blacks across the state, including J.R. Clifford of the Pioneer Press, vehemently criticized the Republican Party. As early as 1884, Clifford advocated independent voting, asking black West Virginians to vote for “men and measures, not parties."14 In the 1888 state elections, black delegates from across the state, teachers and farmers, schooled and unschooled, met in a state convention to nominate candidates for an all black independent ticket. Protesting the limited role assigned to them by local party leaders, these men advocated “independent” voting along with economic and political equality. ${ }^{15}$ However, black leaders were unsuccessful in their attempt to gain concessions from a Republican Party who only recognized their existence when it was time to vote.

By the 1880s, northern industrialists began turning their attention to the rich coalfields of southern West Virginia. Predominately Republican, these men hoped to promote their interests in the state through state legislation and party alliances. The need for an industrial workforce

\footnotetext{
11 “Skinned Him Alive,” Richmond Planet, July 18, 1903.

12 Pioneer Press, July 27, 1912.

13 Logan, Betrayal of the Negro, 43-45.

14 Pioneer Press, November 16, 1912.
} 
demanded the recruitment of black migrants from the southern states of Alabama, Georgia, and North Carolina. In addition to the creation of an industrial workforce, the workers also supplied the Republican Party with additional constituents, most of whom were willing to trade political loyalty for economic security. ${ }^{16}$

Industrialization led to demographic and political shifts among the black population. Bolstered by the votes of the black industrial workers in the southern part of the state, the balance of black political power shifted from its traditional strongholds to the southern coalfields, and from the "old” established leaders to blacks in southern West Virginia who were willing to accommodate white industrialists and politicians. Many of these men were supporters of Booker T. Washington and his policy of accommodation. ${ }^{17}$

As a result, Clifford sought to achieve civil and political rights through the legal system. In the 1890s, he fought two lawsuits against West Virginia’s segregated school system that went before the West Virginia State Supreme Court of Appeals. In Martin v. Board of Education of Paw Paw District, Morgan County, Clifford lost. In Williams vs. Board of Education of Fairfax District, Tucker County, Clifford was victorious in one of the few court decisions south of the Mason-Dixon Line to rule that discrimination on the basis of color was illegal. The decision came two years after the United States Supreme Court decision Plessy v. Ferguson upheld the concept of "separate but equal” accommodations in the South. Clifford also challenged the courts' failure to place African Americans on juries. Indeed, Clifford's attempt to empanel blacks on a jury in Martinsburg, West Virginia, in 1895, led to a violent attack that threatened his life. ${ }^{18}$

\footnotetext{
15 “The W.Va. Afro-American State Nomination,” Pioneer Press, 28 September 28, 1888.

${ }^{16}$ Sheeler, "The Negro in West Virginia, 211.

17 Sheeler, "The Negro in West Virginia, 282-286.

${ }^{18}$ Simmons, Men of Mark, 274-277.
} 
Despite the myth of complete political allegiance to Booker T. Washington within the state, a few black political leaders did turn from state politics to the national arena, forming national alliances with radical thinkers such as W.E.B. Du Bois and William Monroe Trotter. J.R. Clifford joined these men in the American Negro Academy, the re-established National AfroAmerican Council, and the Niagara Movement, in calling for immediate and full manhood rights. J.R. Clifford served as the local organizer for the second Niagara Movement meeting held at Harper's Ferry, West Virginia in $1906 .^{19}$ Two organizations emerged from the Niagara Movement membership, the National Association for the Advancement of Colored People (N.A.A.C.P.), a bi-racial organization composed primarily of white leadership, and the radical National Independent Political League (N.I.P.L.) under the leadership of the volatile William Monroe Trotter and the Reverend J.M. Waldron. Clifford, a founding member of the N.I.P.L., was president of the organization in 1911 and $1912 .^{20}$

In contrast, the growing black electorate in the southern region of the state elected the first black delegate to the state legislature, Christopher Payne, in 1896. The rising number of African American constituents in the southern counties, along with the absolute loyalty of black leaders to the Republican Party, established a circle of dependency between white Republican coal operators and politicians, African-American leaders, and the black working class that enabled operators to maintain control of the industry and provided opportunities for African Americans unavailable elsewhere in the South. Although these new black leaders justified accommodation in the name of protecting their black constituents and the franchise, the votes of black miners buttressed the emerging black middle class and promoted the influence and power of southern black leaders. As a result, those leaders were able to create numerous institutions, such as the

19 “Great Niagara Meeting Opens,” Boston Guardian, August 28, 1906. 
State Industrial Home for Colored Girls, the State Industrial Home for Colored Boys, the West Virginia Colored Deaf and Blind School, West Virginia Colored Home for the Insane, the State Home for the Aged and Infirm Colored Men and Women, the State Colored Tuberculosis Sanitarium, the West Virginia Colored Orphans Home, and the State Bureau of Negro Welfare and Statistics, all established for the benefit and welfare of black West Virginians. These institutions bolstered the black middle-class, providing leadership opportunities as well as placing the control of black welfare under their care. Without a doubt, black leaders established institutions that were beneficial to the black community; yet in doing so, they created more segregated institutions in West Virginia than in any other state in the South.

Any evaluation of black political history in West Virginia must be framed within the context of the social and political events that occurred in America between 1870 and 1930. Works that provide a broad analysis of the Gilded Age and the Progressive Era include Robert H. Wiebe's The Search for Order, 1877-1920, C. Vann Woodward's Origins of the New South, 1877-1913, Edward Ayers’ The Promise of the New South: Life After Reconstruction, Sean Cashman's American in the Gilded Age: From the Death of Lincoln to the Rise of Theodore Roosevelt, Nell Irvin Painter's Standing at Armageddon: the United States, 1877-1919, and Steven J. Diner's A Very Different Age: Americans of the Progressive Era.

In addition to a general knowledge of the period, an understanding of black political thought is necessary for this study. A general narrative on African American life in America during this period can be found in John Hope Franklin and Alfred A. Moss’s From Slavery to Freedom: A History of African Americans. Basic works on black political thought and ideology include August Meier's Negro Thought in America, 1880-1915, Bess Beatty's A Revolution

\footnotetext{
${ }^{20}$ Pioneer Press, September 2, 1911; Charleston Advocate, September 14, 1911; Boston Guardian, September 23,
} 
Gone Backward: The Black Response to National Politics, 1876-1896, Rayford Logan’s The Betrayal of the Negro: From Rutherford B. Hayes to Woodrow Wilson, and Hanes Walton, Jr.'s Black Politics: A Theoretical and Structural Analysis. Works that examine the relationship between African Americans and the major political parties include, but are not limited to, Hanes Walton, Jr.'s Black Republicans: The Politics of the Blacks and Tans, Lawrence Grossman's The Democratic Party and the Negro: Northern and National Politics 1862-92, Stanley Hirshon's Farewell to the Bloody Shirt: Northern Republicans and the Southern Negro, 1877-1893, Nicholas Patler's Jim Crown and the Wilson Administration: Protesting Federal Segregation in the Early Twentieth Century, and Mark Robert Schneider’s "We Return Fighting”: The Civil Rights Movement in the Jazz Age.

In order to establish Clifford's influence on civil and political rights within the context of regional and national history, an investigation of black political life in West Virginia, the upper south, and national black politics was necessary. The majority of information on blacks in West Virginia comes from theses and dissertations. These include John Reuben Sheeler's “The Negro In West Virginia Before 1900,” Forrest Talbott’s “Some Legislative and Legal Aspects of the Negro Question in West Virginia during the Civil War and Reconstruction,” Ann Marie Wynn's "Reconstruction and the Negro in West Virginia," and Lawrence N. Jones' "The Civil Status of Negroes in West Virginia as Reflected in Legislative Acts and Judicial Decisions, 1860-1940.” In addition to the dissertations, two seminal works for African American research in West Virginia are Thomas E. Posey’s The Negro Citizen of West Virginia and Joe W. Trotter's Coal, Class and Color: Blacks in Southern West Virginia 1915-32. In addition, John Alexander Williams' West Virginia and the Captains of Industry provides a good background for West

1911. 
Virginia’s political history and the industrialists that shaped it during this era.

Several works on Clifford's contemporaries illuminated Clifford’s fight for civil and political rights on the national level. Of particular interest were Stephen R. Fox's book The Guardian of Boston: William Monroe Trotter, Louis Harlan’s Booker T. Washington: The Making of a Black Leader, 1856-1901, David Levering Lewis’s groundbreaking and detailed biography, W.E.B. Du Bois: Biography of a Race, 1868-1919, Dickson D. Bruce, Jr.'s Archibald Grimke': Portrait of a Black Independent; Ann Field Alexander's The Rise and Fall of the “Fighting Editor,” John Mitchell, Jr., Paul D. Nelson’s Fredrick L. McGhee: A Life on the Color Line, 1861-191,; and most recently, Anita Hackley-Lambert’s F.H.M. Murray: First Biography of a Forgotten Pioneer for Civil Justice. Percy Edward Murray’s Ph.D. dissertation on Harry Smith, editor of the Cleveland Gazette, titled "Harry Clay Smith, Black Journalist and Legislator," also provided information on the black middle class and elite as did numerous journal articles on individuals who played a role in black politics and the black press between 1880 and 1930.

Clifford participated in numerous black organizations and professional groups, particularly those advocating full civil and political rights. Some of the helpful works focusing on these groups include Willard B. Gatewood's Aristocrats of Color: The Black Elite, 18801920, Jacqueline M. Moore’s Leading the Race: The Transformation of the Black Elite in the Nation's Capital, 1880-1920, Alfred Moss’ The American Negro Academy: Voice of the Talented Tenth, and James Joy’s Transcending the Talented Tenth: Black Leaders and American Intellectuals. The impact of the black press in America is discussed in books such as William G. Jordon’s Black Newspapers \& America’s War for Democracy, 1914-1920 and Martin E. Dunn’s The Black Press, 1827-1890: The Quest for National Identity. 
Of vital interest to this research was J. Clay Smith, Jr.'s monumental and comprehensive history of the legal profession, Emancipation: The Making of the Black Lawyer, 1844-1944. In addition, Paul Finkleman's extensive work on the legal status of African Americans in America, particularly his eleven volume series Race, Law, and American History, 1700-1900: The African American Experience, provided much needed insight and clarity into the world of J.R. Clifford, Esq., Attorney at Law.

However, primary sources provided the majority of the information on the life and activities of John Robert Clifford. Clifford's own words, written in the pages of the Pioneer Press, are the major resource for this work. Documentation of the world he lived in and his view of it fill the pages of the Pioneer Press. He referred to the newspaper as "a labor of love," and it truly is a reflection of his heart. His narratives reveal not only his opinions and beliefs, but the fears and expectations of a generation. More importantly, they reveal a man who viewed character and principles as measurable values rather than abstract ideas. In addition, his columns provide new perspective on the lives of black West Virginians between 1882 and 1918 as well as vital clues to additional information available in court records, historical archives, and numerous black newspapers. Newspapers that provided significant information on the life of John R. Clifford included such well known publications as John Mitchell, Jr.'s Richmond Planet, William Monroe Trotter’s Boston Guardian, and Harry Smith’s Cleveland Gazette. Clifford’s actions, as well as his words, frequently appeared in many West Virginia newspapers, predominantly in extant issues of the African- American press, most notably Matthew T. Whittico and T. Edward Hill’s McDowell Times (1904-1941), published in Keystone, West Virginia, and John C. Gilmer’s Charleston Advocate (1907-1912), published in Charleston, West Virginia. ${ }^{21}$

\footnotetext{
${ }^{21}$ Matthew T. Whittico was the publisher and editor of the McDowell Times; T. Edward Hill served as its business
} 
Following the introduction, this study is divided into five chapters that illustrate particular aspects or periods in J.R. Clifford's life. Chapter One focuses on the events that shaped Clifford as a man, from his early childhood through his education at Storer College in Harpers Ferry, West Virginia. Strong-willed, stubborn, and forceful, Clifford inherited many of his traits from a grandfather who was equally willing to fight for his rights. In addition, his status as a free African American in the slave state of Virginia shaped the man he was to become. Despite legal limitations, he lived a life of peaceful co-existence among neighboring whites. Beyond the hills and valleys of his Williamsport, Virginia, home, free African Americans faced increasing restrictions as the nation moved closer to civil war. At the same time, his free status afforded him the opportunity to leave the state for an integrated education in Chicago, Illinois, an opportunity denied to the majority of black Americans. It was there that he enlisted in the army and fought to end slavery. Following the war, an education at Storer College taught him strong moral and ethical standards; and a lynching emphasized the need to carry on the battle for full equality and justice under the law. One led to class conflict, the other to racial and political discord. Chapter Two examines the conflict that erupted between Clifford and local Republican leaders when Clifford called for equality between the races. The hostility increased with the establishment of his newspaper, the Pioneer Press, in 1882, and when he passed the bar in 1887. When numerous attempts at bribery and intimidation failed, his enemies sought to imprison him, physically harm him, and to ruin the Pioneer Press financially. In the end, his childhood experiences, his time as a soldier, his education, as well as his local battles for social, economic, and political rights served to develop the thing he valued the most—character.

During the 1890s, Clifford fought the most important legal battles of his career. Chapter 
Three examines Clifford's legal activities with emphasis on two cases he argued before the West Virginia State Supreme Court against West Virginia’s segregated school system, Martin v. Board of Education of Paw Paw District, Morgan County and Williams v. Board of Education of Fairfax District, Tucker County. This chapter also scrutinizes another significant courtroom battle, Clifford's effort to empanel blacks on a jury in 1895 and the violent reaction it evoked. Chapter Four reveals Clifford's involvement in numerous organizations and how those organizations were a reflection of his growing militancy in the face of deteriorating race relations, increasing discrimination, and persistent racial violence during an era commonly known as the "Age of Jim Crow.”

Clifford's thoughts about numerous subjects, and what they reveal about him, are the subject of Chapter Five. Known as the "Dean of Journalism” among his peers, the Pioneer Press operated for nearly thirty-six years under Clifford's direction. ${ }^{22}$ During that time, Clifford documented the history of the era not only through his own eyes, but through the eyes of the black community as well. Clifford provided black West Virginians with information on issues that concerned them and, at the same time, he provided them with a voice. Chapter Six, the conclusion, considers “the measure of a man:” Clifford's impact on the social, civil, and political structure during his lifetime, his influence on the next generation of African American attorneys, and the significance of his legacy for Americans, black and white, today.

One goal of this study is to inform readers of the struggles and achievements of John Robert Clifford. Secondly, it is written in the hope that people will actually get to know and understand one extraordinary man who lived in a pivotal moment in time, and to illustrate how this one man's life, based on character, principle, and the desire to improve the lives of black

following Starks death in April of 1908. 
Americans, impacted generations.

${ }^{22}$ Comments between Harry Smith and J.R. Clifford, Pioneer Press, September 25, 1915. 


\section{CHAPTER ONE}

\section{WITHOUT "REMORSE OR CONSCIENCE" Seeds of Rebellion}

"When a boy I was a farmer, then a waiter, next a barber, then a teacher, next an editor and last a lawyer and the first to be admitted to practice in my state. I used them all as a means to the final end."1

At midnight on August 13, 1874, a crowd gathered in Martinsburg, West Virginia. They took from the county jail a black man named John Taliaferro, and without any authority, lynched him. This lynching occurred despite recent speeches in the United States Senate on behalf of law and order and the necessity of its application to all American citizens regardless of color.

Without question, it had a profound impact on every African American living in Berkeley County, West Virginia, perhaps none more so than on a young African American named John R. Clifford. Years later when writing on his political choices, Clifford, who was twenty-five years old at the time of the lynching, stated, "I could go back from childhood—but I will go no further than the $13^{\text {th }}$ of August, ' 74 , and from that date to this present time I have no remorse or conscience."2 $^{2}$

Although the Taliaferro lynching did have a profound impact on Clifford's social and political consciousness, Clifford's path from the third son born to a farming family in rural Hardy County, West Virginia, to a civil rights pioneer in his home state and the nation actually did began in his childhood. Born in Williamsport, Virginia, (present-day Grant County, West Virginia) on September 13, 1848, Clifford was the son of free African Americans, Isaac and Mary S. Kent Clifford. Clifford's status as a free African American in the ante-bellum south afforded him opportunities, however limited, unavailable to enslaved blacks in the region and provided a

\footnotetext{
${ }^{1}$ J.R. Clifford, “Annual Address of the National Independent Political League,” Pioneer Press, September 2, 1911.

2 "To the Editors of the Herald: And Their Cosmo-Political Band of Republican Rulers or Ruiners," Martinsburg Independent, May 10, 1884.
} 
basis for his integrated primary education as well as his staunch belief in racial equality. ${ }^{3}$

Freedom was crucial to the Clifford family and it was a condition they were willing to fight for regardless of the odds. As early as 1796, the family patriarch, Isaac Clifford, filed a lawsuit against a white man named James Ryan, charging him with battery and false imprisonment. Apparently Ryan accosted and detained Clifford, who was a free black known as "black Isaac," in an attempt to sell him as a slave. ${ }^{4}$ If it was surprising that a young black man in the slave state of Virginia had the courage and daring to challenge a white man in a court of law, it is not necessarily surprising that he won. The egalitarian philosophy and passionate rhetoric of the American Revolution inspired the manumission of slaves and strengthened the legal status of free African Americans for at least two decades after the war. ${ }^{5}$ In addition to Isaac Clifford's victory in 1796, four other Hardy County blacks, Isaac, Will, Lucy, and Dinah, petitioned the county court in September of 1803 to have themselves declared free on the basis of being held in illegal servitude. Two years later, the court ruled in their favor. ${ }^{6}$ However, the growing number of free blacks led to increasing restrictions throughout the antebellum era. By the start of the Civil War, the status of free blacks diminished to the point where there was little distinction between free blacks and slaves. Yet Isaac Clifford’s legacy, his courage and determination,

\footnotetext{
${ }^{3}$ Luther Porter Jackson, Free Negro Labor and Property Holding in Virginia, 1830-1860 (New York: D. AppletonCentury Company, 1942), 4, 11, 20-22, 31. Free blacks in Virginia were forbidden by law to vote, hold office, sit on juries, bear witness against whites, and to move freely from one place to another. Following Nat Turner's insurrection, the Virginia legislature passed additional laws restricting free blacks between 1830 and 1860. These measures included denying free blacks the right to a trial by jury, attempts to remove free blacks from the state, making it unlawful to teach free blacks to read or write, forbidding free blacks who left the state from returning (even if it was for an education), the prohibition of preaching, and taking away their right to own slaves (which often was used as a means for manumission). The one right that free blacks maintained was the right to acquire, own, and sell property. While many of these laws may not have been strictly enforced in western Virginia, the laws still applied to free blacks living there. Communities varied in their application of the laws as well as in the number of extra-legal actions, which often included violence.

${ }^{4}$ Hardy County Court Book No.1, Hardy County Circuit Clerk’s Office, Hardy County Courthouse, Moorefield, West Virginia (hereafter HCCCO; and Rosemary Clifford McDaniel Papers (hereafter RCMP).

${ }^{5}$ John Hope Franklin and Alfred A. Moss, Jr., eds., From Slavery to Freedom: A History of African Americans (New York: McGraw Hill, Inc., 1994), 148-151.
} 
materialized in future generations, particularly in J.R. Clifford, whose actions often reflected the strength of character and quest for equality found in his great-grandfather. ${ }^{7}$

J.R. Clifford's parents, Isaac, the grandson of the first Isaac Clifford, and Mary Satilp(hi)a Kent Clifford gave birth to three sons, Theodore, David, and John Robert. Mary Kent Clifford died when J.R. was small, and although Isaac married again, J.R. spent much of his time at the home of his maternal grandparents, Evan and Priscilla Kent. Isaac’s second wife, Susan Lowry died in 1857 after the birth of their second child, Mary E. According to the 1860 Hardy County census, Isaac Clifford, listed as a thirty-six-year-old male mulatto, and his third wife, Elizabeth Jane Redman, 23, lived in a household with Theodore and John, three-year-old Mary, and the first of their seven children, three month old Jacob. Isaac was a farmer with $\$ 400.00$ worth of property and neither Isaac nor Elizabeth could read or write. ${ }^{8}$ The family lived in Williamsport, Virginia, an isolated farm community nestled along Patterson Creek in the Allegheny Mountains. ${ }^{9}$ Williamsport was a place "supremely loved” by Clifford, where “a horse-sensed good old grandmother lived and cared” for him, herbs “cured the ills of life,” people learned "spinning, knitting, weaving, and making linen,” and could be “independent."10 Clifford referred to his childhood as "happy days," "when everybody raised what the family needed” for "health, comfort, warmth, and independence.”11 Clearly “independence” was something to be cherished in the Clifford family_not just in the physical sense, but in thoughts and actions as well.

\footnotetext{
${ }^{6}$ Stephen Smith, "Secession, War and Rebirth: The South Branch of the Potomac," (Masters thesis, West Virginia University, 2000), 33-34.

${ }^{7}$ Franklin and Moss, From Slavery to Freedom, 151.

${ }^{8}$ Census of Population, Eighth Census of the United States 1860, Hardy County, Second District, 132, West Virginia; and Rosemary Clifford McDaniel, "The Early History of the Clifford Family of Maryland, Virginia/West Virginia, Pennsylvania \& Ohio: Descendants of Isaac Clifford, The Patriarch, paper presented at the Kent-Clifford Family Reunion, 13-14 August 2004, Toronto, Ontario, RCMP, 6. Theodore Kent Clifford (1844-1908) served in the West Virginia $45^{\text {th }}$ Colored Infantry during the Civil War and later became a minister in the United Brethren Church. In the 1860 census, David (1846-1894) was living with Evan Kent and there is scant information on his later years.

${ }^{9}$ Paul Clifford, unfinished manuscript, Paul and Margaret Washington Clifford Papers, (hereafter PMWCP).

${ }^{10}$ Pioneer Press, September 12, 1914.
} 
For many African Americans, both slave and free, the road to independence came through education. ${ }^{12}$ In 1860, Hardy County had 270 free African Americans, 1,073 slaves, and 8,521 whites. ${ }^{13}$ Since Virginia law dictated that blacks could not be taught to read and write, there were no schools for the 1,343 black children in Hardy County, Virginia. ${ }^{14}$ In addition, the Virginia Code of 1860 prohibited free blacks who left the state, even for an education, from returning. The impending conflict between the North and the South made times even more uncertain, particularly for free African Americans in the border region who were often suspected of aiding fugitive slaves and, later, serving as informants for the Union army. ${ }^{15}$ Indeed, as Waitman T. Willey stated in an address to the First Constitutional Convention of West Virginia in 1863, "There is nothing in the soil or climate of West Virginia to attract a free negro, but much to repel him." ${ }^{16}$ Yet Clifford's memory of that period reveals the close relationships that often developed between black and white children of the era and how children, often blind to the realities of war, engaged in make-believe battles and the "glory" of war. Clifford exposed this childhood innocence in a tribute to his white friend, H.C. Berry, in the following passage:

During the War of the Rebellion at Moorefield, Hardy County, (then Virginia) the following two "generals" were born and lived. In Phillip Shear's store one night they got into an argument, and it was settled by a decision that it be fought out on a chosen battlefield with slings and four wooden cannon. A

\footnotetext{
${ }^{11}$ Pioneer Press, January 17, 1914.

${ }^{12}$ Douglass, Fredrick, Narrative of the Life of Fredrick Douglass, An American Slave (Boston: Anti-Slavery Office, No. 25 Cornhill, 1845; reprint, New York: New American Library, 1968), 49; Booker T. Washington, "Some Results of the Armstrong Idea,” The Southern Workman, XXXVIII (1909): 176, 169-172.

${ }^{13}$ John Rueben Sheeler, “The Negro In West Virginia Before 1900 (Ph.D. dissertation, West Virginia University, 1954), 281-282.

${ }^{14}$ Franklin and Moss, From Slavery to Freedom, 160-161; Talbott, "Some Legislative and Legal Aspects of the Negro Question in West Virginia,” (Master’s thesis, University of Minnesota, 1942), 18. Although blacks could not attend school, many received private instruction despite the proscribed penalties.

${ }^{15}$ Smith, "Secession, War and Rebirth," 77.

${ }^{16}$ West Virginia Archives and History, “Address of the Hon. Waitman T. Willey” 12 February 1863 in A State of Convenience: The Creation of West Virginia, Debates and Proceedings of the First Constitutional Convention of West Virginia (Charleston, West Virginia: West Virginia Division of Culture and History, 2006), available from http://www.wvculture.org/History/statehood/cc021263.html, 18.
} 
blacksmith named Newhouse made two cannon for one of the "generals" and another blacksmith named Yokum, made the other two. The cannon were bound with iron bands. After a month's drilling and preparation the battle on town hill, about a mile south of Moorefield took place. Half of the soldiers were white, the rest colored. The battle had gone on for about an hour-during which time two charges had been made, and had a dozen pretty badly wounded. The colored "general" preceding what was to be an intrepid charge, overloaded one of his cannon, causing it to burst, and hurt two of his men and so confused the others, that they retreated in bad order with the whites close on their heels. Up to that time the colored troops had the better of the fight. They were run to, and through the South Branch of the Potomac. The officers were H.C. Berry and J.R. Clifford and from that time on we were called "generals." We have talked it over and laughed heartily many a time, and until last Monday have always saluted each other as 'general.'

We have always been friends, and were when at war ...

Peace to his ashes-rest to his soul. ${ }^{17}$

Stephen Smith, in his history of the Civil War in the South Branch Valley of the Potomac, states that "for some of the young men of Moorefield in the summer of 1861, war was still a game" and rightly perceives that "the light of youth was darkened by the reality of war.” ${ }^{18}$ Hardy County (Fig. 1.1) was a contentious area, where the battle lines between North and South were firmly established and cemented with the legal division of the county immediately following the war in February of 1866. Throughout the war, conflict erupted among the citizens of the county, with most residents of what constitutes present-day Hardy County supporting the South and the majority of those living in the area that would become Grant County supporting the Union cause. ${ }^{19}$ Divided both economically and politically, the valley was “a tinderbox of war spirit” where skirmishes constantly took place between Hardy "Grays” and "Blues” loyal to the South and "Home Guards" who sought to protect Union

\footnotetext{
${ }^{17}$ Pioneer Press, October 4, 1913. The Henry C. Berry that Clifford refers to was the son of Joseph E. Berry, a tailor in Hardy County. H.C. Bailey was approximately six years younger than Clifford. Newhouse and Yokum were both white.

${ }^{18}$ Smith, "Secession, War and Rebirth," 74-76.

${ }^{19}$ E.L. Judy, History of Grant and Hardy Counties, West Virginia (Charleston, W.Va.: Charleston Printing Co., 1951), 237.
} 
interests in the county. Hardy County was also home of the famous McNeill's Rangers, a Confederate guerilla unit. A dividing line between slaveholding planters and yeoman farmers and laborers with conflicting ideologies, a border between north and south and east and west, with a direct link to the Shenandoah Valley and the Baltimore and Ohio Railroad, the valley played a central role in the military activities of both Federal and Confederate troops. It was, as Smith describes it, "a divided county within a divided state of a divided union.,20

Whether it was Isaac Clifford's desire for J.R. to have an education, or an attempt to remove John from the battle-torn region, he sent his son to Chicago, Illinois, in May of 1864 to attend school. In Chicago, J.R. lived with a family friend, a young white man named John J. Healy and his wife Ellen (Nellie), and attended an integrated school. For a young man who grew up in rural Hardy County where the school board made no provisions for black education, the emphasis on learning without regard to color must have been astounding for Clifford. His experiences in Chicago, among the Healy family and in the integrated schools, encouraged him to strive continually for improvement and reinforced his belief in equality among the races. Clifford recalled:

Our early life was spent in the schools of Chicago, never sitting by the side of children of darker color ... about ten years later, we returned to Chicago and going to the Appellate Court found our class and seat mate, Mr. Frank Lane, head clerk over more than a hundred clerks. We embraced each other ... he got his buggy and took us all over all of our prank grounds and $\mathrm{O}$ ! what a time we had that day: One of the old teachers threw her arms around us and many of the then boys were then men in

\footnotetext{
${ }^{20}$ Smith, "Secession, War and Rebirth,” 38, 46-47, 55, 62. The area was occupied by Federal and/or Confederate troops as early as August of 1861. Located between the Shenandoah Valley and the Upper Potomac region, the area provided livestock for the Confederate army, contained resources such as coal and timber, and was central to the main lines of the B \& O Railroad. In addition to Smith, for information on military campaigns in this area, see "Valley Campaigns 1861-1865," http://www.cr.nps.gov/hps/ABPP/shenandoah/svs2-4.html and "The Civil War in the Shenandoah Valley,” http://angelfire.com/va3/valleywar/battle/61campaign.html.
} 
various kinds of business and all greeted us and Mrs. Curtain, one of the noblest and sweetest women Chicago ever owned and for whom the whole city mourned by order of authority wept and greeted us as a mother would her long gone and returned son. ${ }^{21}$

Clifford admired and respected Healy, calling him “my best earthly friend.” Indeed, although Healy was only five years older than him, Clifford wrote a tribute to Healy following his death in 1910 stating that Healy was "a loving tender father in goodness to the editor of the Pioneer Press" and that "If our [Clifford's] life amounts to anything, the credit is placed to Captain John J. Healy.”22 Healy, who rose to the rank of Captain after four years of service in the $23^{\text {rd }}$ Regiment of the Illinois Volunteers known as Mulligan’s Irish Brigade and was critically injured at the Second Battle of Kernstown in July of 1864, accompanied J.R. to the recruiting station where he passed muster in March of $1865 .{ }^{23}$ After volunteering for the Union Army in Chicago, Clifford became a private, then a corporal, in the $13^{\text {th }}$ U.S. Colored Heavy Artillery. Officially, the $13^{\text {th }}$ Regiment organized at Camp Nelson, Kentucky, on June 23, 1865. However,

\footnotetext{
${ }^{21}$ John Healy, “Affidavit to Origin of Disability,” n.d. Clifford Pension File, 29 May 1899, Dept. of Interior, Bureau of Pensions (hereafter BP), RCMP; Pioneer Press, August 1, 1914; The West Virginia Legislature repealed Sections 33-37 of Chapter 198 of the Virginia Code that forbade the return of free blacks who left the state and penalized whites who taught blacks to read or write in October of 1863. For more information see Talbott, "Some Legislative and Legal Aspects," 48-49; For information on the Healys and the early black schools in Chicago see Weston Arthur Goodspeed and Daniel D. Healy, Cook County, Illinois: Being a General Survey of Cook County History, Including a Condensed History of Chicago and Special Account of Districts Outside the City Limits; From the Earliest Settlement to the Present Time Vol. II (Chicago: The Goodspeed Historical Association, 1909), 100, 123-130, 795. John J. Healy was the son of John and Ellen O’Brien Healy from Kerry, Ireland. Born in Ireland in 1843, Healy was five years older than Clifford. The Healy family came to the United States in 1849. Healy and his wife Ellen had two children Mary, called Minnie, who was born in 1866 while Clifford resided with the couple, and John J. Healy, Jr. (1870-1912). John J. Healy was an Illinois delegate to the 1908 Republican National Convention and died in Chicago on May 8, 1910.

${ }_{22}^{2}$ Pioneer Press, May 13, 1911.

${ }^{23}$ Pioneer Press, May 13, 1911; Healy, “Affidavit,” (BP), RCMP. The author believes J.R. Clifford met John J. Healy because of Healy's service in the $23^{\text {rd }}$ Illinois Infantry. Created in Chicago in June of 1861, "Mulligan's Irish Brigade" under James A Mulligan, an Irish-American lawyer in Chicago, participated in Union campaigns in valley of the South Branch of the Potomac River near Moorefield and Williamsport, Va. (now West Virginia). The brigade arrived in 1862 and spent two years in western Virginia engaged in skirmishes with rebel guerillas. The $23^{\text {rd }}$ Illinois built "Fort Mulligan" at nearby Petersburg in 1863. Tents covered the fields near the Clifford home place between 1861 and 1865 when Major General John C. Fremont camped in the area with almost twenty thousand federal troops in the spring of 1862, numerous troops served there during the construction of Fort Mulligan, and infantrymen from Mulligan's Irish Brigade made their winter quarters the area. For information on Fort Mulligan see http://grantcountypress.com/fort-mulligan.html. The exact date of Clifford's move to Chicago is based on conflicting
} 
Companies A through $\mathrm{E}$ of the $13^{\text {th }}$ Regiment formed prior to that date, between October of 1864 and May of 1865. Clifford's company, F, organized in May of 1865, consisted of men from Illinois, Michigan, and Kentucky. Regimental staff officers included Colonel Jacob T. Foster, the Commanding Officer, and Lt. Colonel George Parker. The highest ranking African American in the regiment was Sergeant Major Francis A. Adams. Camp Nelson was one of the largest recruitment camps for African Americans in the United States, establishing eight regiments of U.S. Colored Troops and training three others. Garrisoned by 3,000 to 8,000 soldiers, Camp Nelson served as a supply center, recruitment and training center, and a refugee camp for African Americans. Upon arrival, the scene of thousands upon thousands of African American soldiers readying for battle must have filled the young Clifford with awe. Sergeant Elijah Marrs, a member of the $12^{\text {th }}$ USCHA stationed at Camp Nelson described the feeling best when he stated, "I felt freedom in my bones, and when I saw the American eagle with outspread wings, upon the American flag, with the motto E Pluribus Unum, the thought came to me, 'Give me liberty or give me death.'” Another soldier, Sergeant William A. Warfield of the $119^{\text {th }}$ USCI, marveled at the Fourth of July celebration at Camp Nelson, stating, “To see so many thousands, who a year ago were slaves, congregate in the heart of a slave State and celebrate the day sacred to the cause of freedom, 'with none to molest or make afraid,' was a grand spectacle.”24

Although Clifford served as an artilleryman, he also did detail in the hospital, dispensing medicine until his honorable discharge at Louisville, Kentucky, in November of $1865 .{ }^{25}$ During the fighting, Clifford reported, "a dear friend of ours was shot from our side into eternity. Did we

sources. Clifford may have accompanied or aided the injured Healy when he went home to Chicago.

${ }^{24}$ W. Stephen McBride, "Camp Nelson: A Fortified Union Supply Depot, Recruitment Center, and African American Refugee Camp in Central Kentucky http://www.bjmjr.com/camp_nelson/cn_mcbride.htm, 1-6; and W. Stephen McBride, Summary of $13^{\text {th }}$ U.S. Heavy Artillery,” Camp Nelson Heritage Park, Nicholasville, Kentucky. For a list of the men in the $13^{\text {th }}$ U.S. Heavy Artillery, Company F, see Appendix I.

${ }^{25}$ John R. Clifford, “Declaration for Increase in Pension,” 18 September 1905, 
sit down and cry? No! and no!! again, but on the contrary shot the quicker, and tried to aim with more precision—indeed it gave us new ambition to fight." ${ }^{26}$ However, Clifford’s desire and willingness to serve his country did not guarantee him equality, or even respect, among all Union troops. A history of the Union regiments in Kentucky published under the auspices of the Union Soldiers and Sailors Monument Association in 1897 documents the status many white soldiers afforded to their black compatriots in the Civil War. In an appendix titled "Colored Soldiers," the author writes "the enlistment of colored men in Kentucky was in organizations belonging directly to the United States government” and known as "United States troops.” Therefore, “as they were never in or connected with the Kentucky regiments, an account of them in no way belongs to this work, which is a history of the Union state organizations.”27 Always proud of his military service, Clifford often criticized America's failure to provide equality and civil rights for black soldiers and he often referred to the treatment afforded to them in his paper and in speeches. Among his statements were:

We won our laurels on the bloody battlefields and saved the union along with hammering the shackles off our heels to the number of four million, and with folded arms and clam silence, they have allowed us to be disfranchised, lynched and burnt at the stake. ${ }^{28}$

We were on the fields of battle in the rebellion, are old and gray, but as active, well and game as then, and can march as far and shoot as well as ever, and although treated worse than dogs — can't go to see picture shows, eat in 2x2 restaurants, jimcrowed on cars, send our children to mixed schools, sit on juries and God only knows what not, we shall fight for the country we love and call ours . ... ${ }^{29}$

Clifford urged African Americans to push for all the rights guaranteed for American citizens in the Constitution precisely because they were, according to him,

Rights vouched safe to you by 449 bloody battles fought by nearly 200,000 brave blacks who donned the blue and barred their breasts for your freedom and the union of the

\footnotetext{
(BP), RCMP.

${ }^{26}$ Pioneer Press, October 26, 1912.

27 “Colored Soldiers,” The Union Regiments of Kentucky (Louisville: Courier-Journal Job Printing Company, 1897),

${ }^{28}$ Pioneer Press, August 8, 1916.

${ }^{29}$ Pioneer Press, July 31, 1915.
} 
country. $^{30}$

Consequently, their battles, and their lives, demanded equality.

After the war, Clifford returned to Chicago where he again lived with John Healy between 1865 and 1868 while attending high school. This friendship, between a white Irishman from the city of Chicago and a black American from rural Hardy County, lasted for a lifetime. In addition to Clifford's own visits to Chicago, he sent his daughter Helen to live and work with the Healy’s when she was a teenager. After more than forty-six years of friendship, Clifford visited John Healy for the last time two days before Healy’s death on May 8, 1910. ${ }^{31}$

Clifford worked as a waiter and a barber following graduation before moving to Zeno, Muskingum County, Ohio, where an uncle, Saul Clifford, lived. Always eager to learn, Clifford continued his education while living in Ohio, attending another school taught by Miss Effie McKnight and a writing school conducted by Professor D.A. White. ${ }^{32}$ Clifford then moved back to West Virginia, where he worked as a laborer in the city of Wheeling in 1868 and 1869 before returning to Moorefield in Hardy County where he taught school for the first time in 1870. He recalled that in the years immediately following the war, "both parents and children were eager and hungry for learning.”33 This compelling desire on the part of African Americans to learn led Clifford back to Wheeling where he conducted a writing school for over one hundred African Americans while making a living as a barber on the west side of Fifth-Street between Pine and Vine. $^{34}$

For Clifford, the changes that occurred in West Virginia during his absence must have

\footnotetext{
30 John R. Clifford, “Annual Address,” Pioneer Press, September 2, 1911.

31 Twelfth Census of Population 1900, Cook County, Illinois; Pioneer Press, May 13, 1911.

${ }^{32}$ Pioneer Press, June 6, 1915; “Declaration for Pension,” 13 September 1910 (BP), RCMP.

${ }^{33}$ William's Wheeling Directory, 1868-69, Vol. 4 (Wheeling: A.W. Paul \& Co., 1868), 67; and Pioneer Press, June 5, 1915, 2.

${ }^{34}$ Sheriff's Wheeling Directory, 1872-73 (Wheeling: Paull \& Orr, 1872), 74.
} 
been striking. He had left the state with the enthusiasm of youth, traveled from the rural foothills of the Appalachian Mountains to the urban life of Chicago, acquired a basic education long denied, and recognized the realism, as well as the idealism, of war. The eyes that now viewed this fledgling state were the eyes of a man.

Devoted to learning and anxious for full citizenship rights, blacks in western Virginia were striving for a better life amid an atmosphere of uncertainty. Under the direction of Robert Simmons, the African American community of Parkersburg, Virginia created the first school for black students in January of 1862 within the boundaries of what would later become West Virginia. Recognized on June $20^{\text {th }}$ of 1863 , the new state of West Virginia passed a law requiring the establishment of schools for free persons of color, but two years later there were still no schools listed for African Americans in school reports. The black school at Parkersburg became part of the public school system in 1866, making it the first public school for African Americans south of the Mason-Dixon Line. Under the public school system, the state provided for the establishment of black schools wherever thirty or more students existed. ${ }^{35}$ However, the law failed to address the educational needs of students living in rural areas and created steadfast opposition to black education in the regions containing the highest number of African Americans where the education of blacks threatened established social customs, particularly in Kanawha County in southern West Virginia and the eastern panhandle counties of Jefferson and Berkeley. ${ }^{36}$

At the end of the Civil War, two organizations moved into the Shenandoah Valley to aid the growing number of freedmen in the region, the Free Will Baptist Society and the Bureau of Refugees, Freedmen, and Abandoned Lands (Freedmen’s Bureau). Reverend Nathan C. Brackett from Maine led the educational efforts in the valley for the Baptists, setting up mission schools in

\footnotetext{
${ }^{35}$ Anne Marie Wynne, “Reconstruction and the Negro in West Virginia,” (Master’s thesis, University of Maryland),
} 
Martinsburg in Berkeley County, and Harpers Ferry, Shepherdstown, and Charles Town in Jefferson County. The Freedmen's Bureau arrived in March of 1865 under the direction of General Oliver O. Howard, Head Commissioner, and Captain Brubaker, the agent in charge. ${ }^{37}$ African Americans in the region, and the organizations that came to provide education and relief for them, often were met with deception, hostility, and, occasionally, violence. ${ }^{38}$

Annie Dudley and Sara Foster were among the first mission teachers to arrive in Harpers Ferry from Maine in 1865. Due to local animosity, Dudley arrived in Charles Town to institute a mission school under military escort and had no place to permanently board for nearly two months. At Martinsburg, Dudley, along with the other teachers, received frequent visits from cadets on leave from the Virginia Military Institute in Lexington, Virginia, who taunted the teachers and pupils and, one night, demanded one of the students to shoot. Constant intrusions into the schoolrooms, by locals intending to scare the teachers away from the schools, went on for several years. Vandalism frequently occurred. The townspeople also subjected the teachers to social proscription, ostracizing them from the white communities and treating them with contempt, often referring to them as the "nigger teachers." 39

Prominent local whites who attempted to help African Americans, the Freewill Baptists, or the Freedmen’s Bureau also received censure. Joseph T. Hoke, Berkeley County's Prosecuting Attorney, and his family met with sharp criticism from the Martinsburg community for boarding mission teacher Sara Foster in their home. A confirmed Unionist, educated at Rock River Seminary in Illinois, Oberlin College in Ohio, and Hillsdale College, a Free Will Baptist school in

\footnotetext{
40-44; Talbott, 62-67.

${ }^{36}$ Wynne, "Reconstruction and the Negro," 46.

${ }^{37}$ Wynne, "Reconstruction and the Negro," 75-78.

${ }^{38}$ Wynne, "Reconstruction and the Negro, 75-78; Dawne Raines Burke, "Storer College: A Hope for Redemption in the Shadow of Slavery, 1865-1955," (Ph.d. dissertation, Virginia Polytechnic Institute \& State College, 2004), 104.

${ }^{39}$ Burke, "Storer College," 111-114.
} 
Michigan, Hoke graduated from Michigan University with a law degree in 1864 and returned to Berkeley County where he was admitted to the bar and elected prosecuting attorney in 1864. He also began publishing a pro-Unionist newspaper, The Berkeley Union. ${ }^{40}$ His boarder, ardent in her beliefs and determined not “to be driven off by the roughs,” walked down Queen Street in Martinsburg with an adult student named Mr. Hopewell. Considered “inappropriate conduct” within the local culture, the close proximity between a white female and a black male escalated the existing tensions between the freedmen's school and the white community. ${ }^{41}$ Alarmed, Hoke feared there would be mob action. Captain J.H. McKenzie, an Assistant Superintendent of the Freedmen's Bureau at Martinsburg, also fearing the rising tensions, accompanied Foster from the schoolroom under guard. ${ }^{42}$

While southern sympathizers used ostracism and intimidation to discourage the enthusiasm of the Baptist teachers, they were more willing to use violence against Freedmen’s Bureau officials to prevent the establishment of schools. Ex-rebel soldiers shot at Captain Brubaker and H.V. Daniels when they attempted to build a school for African Americans in nearby Smithfield. ${ }^{43}$

When intimidation and violence failed, the Harpers Ferry Township Board of Education in Jefferson County resorted to deception to avoid the establishment and cost of black schools as required by the state legislature. In 1866, two African Americans, Thornton Moulton and Isaac Gilbertson, filed a lawsuit against the Harpers Ferry Board of Education in Jefferson County claiming the board deprived their children of rightful education. The township, in order to avoid spending school funds to build a black school, reported only twenty-two black pupils instead of

\footnotetext{
${ }^{40}$ Burke, “Storer College,” 167-171.

${ }^{41}$ Foster, "Letters from West Virginia, 1865-1866, 49, as quoted in Burke, "Storer College,” 114.

${ }^{42}$ Burke, "Storer College," 115; and George W. Atkinson and Alvaro F. Gibbens, Prominent Men of West Virginia (Wheeling: W.L. Callin, 1890), 454-458.
} 
the actual number of thirty-seven. The court ruled in favor of the black litigants, and ordered the board to pay court costs and \$144 dollars in school funds, then threatened the board with imprisonment if they did not comply. ${ }^{44}$

Not only did the presence of the Freewill Baptists and the Freedmen’s Bureau alter the established social mores of the region, it also threatened the political order. Their efforts to inform African Americans of their political and civil rights angered conservative Democrats, the political majority in the eastern panhandle. Critics of the Bureau accused it of sustaining radicalism and promoting the Republican Party. According to rumors, Union Leagues operated in several townships of Jefferson Count and black citizens did attend the meetings. The leagues educated African Americans on the rights of citizenship, rights the locals frequently attempted to impede, and provided them with measures to overcome injustices. ${ }^{45}$

According to Bureau reports, the "greatest abridgement of civil rights” occurred among justices of the peace, who refused to act in biracial conflicts due to public opinion, and judges whose attitudes prevented them from executing the law impartially. Brubaker often had cases involving African Americans in Jefferson and Berkeley Counties removed to other districts due to racism. $^{46}$

Animosity increased in the fall of 1867 when the Freewill Baptists opened Storer College at Harpers Ferry in Jefferson County. The first institution to offer higher education and normal school training for African Americans in West Virginia, it immediately sparked intense opposition not only in the eastern panhandle, but throughout the state. ${ }^{47}$ John Storer of Seaford, Maine bestowed funding for Storer College with the stipulation that the school must be open to

\footnotetext{
${ }^{43}$ Burke, "Storer College," 57-58.

${ }^{44}$ Wynne, "Reconstruction and the Negro," 56-57.

${ }^{45}$ Virginia Free Press, August 15, 20, 1867; Wynne, "Reconstruction and the Negro,” 62-63.

${ }^{46}$ Wynne, "Reconstruction and the Negro," 100-101.
} 
both sexes without distinction to race or color. ${ }^{48}$ Jefferson County’s 3,488 black citizens represented the largest African American population of any county in the new state, and the very idea of integrated education outraged conservatives who abhorred the idea of "racial mixing." Whites who "despised" the new school frequently threatened to burn it down, forcing "brave colored men with implements of war” to guard it night after night. ${ }^{49}$

Efforts to have the state legislature in Wheeling incorporate Storer College in the spring of 1868 were questionable. Martinsburg attorney Joseph T. Hoke, who served as the local legal council for the Free Will Baptists and held membership on the Baptist's Commission for the Promotion of Education in the South, assisted the Baptists with the charter for Storer College. Elected in 1866, Hoke was also a senator in the West Virginia Legislature. Following the legislature's intense debate over the phrase "without distinction of race, or color," Hoke realized there would be only a slight margin on the vote for Storer. Knowing his affiliation with the Commission required him to abstain from the vote, Hoke temporarily resigned his appointment to the Baptist commission just minutes before the legislative vote. A fortuitous decision, Hoke "cast the decisive vote, for the success of the measure turned upon his foresight and the Act passed by one majority. ${ }^{\text {50 }}$ After the vote, Hoke resumed his appointment to the Baptist Commission which then convened as the Storer College Board of Trustees and remained an avid supporter of the college. $^{51}$

Storer College received its charter on March 3, 1868, and whites immediately used it in conjunction with the Negro suffrage issue as campaign material. Both Democrats and Republicans voted in favor of the charter, leading the Republican Wheeling Intelligencer to taunt

\footnotetext{
${ }^{47}$ Talbott, "Some Legislative and Legal Aspects," 64-67.

${ }^{48}$ Talbott, "Some Legislative and Legal Aspects," 64-67; and Burke, "Storer College,” 8, 122-123.

${ }^{49}$ Sheeler, “The Negro in West Virginia,” 277-286; “Storer College Commencement,” Pioneer Press, May 1887.

${ }^{50}$ Kate J. Anthony, A Brief Historical Sketch: Storer College, as quoted in Burke, “Storer College,” 172.
} 
the Democratic supporters by asking them if the democracy was going for “'nigger equality,' 'nigger’ schools, etc.? Are we going to see a 'nigger suffrage’ plank in their platform in this summer's campaign? Do these Democratic members want their daughters to 'marry a nigger'? If not what means this vote to allow colored youth to go to college alongside white children?”52 However, Johnson N. Camden, Democratic candidate for Governor in the fall of 1868, used the charter issue to swing voters away from the "radical" Republicans controlling the state stating, "you see in this a direct effort on the part of the Legislature to mould and educate the minds of the youth of our State in favor of negro equality by making them the associates and companions of negroes in our schools and colleges."53 By linking black suffrage with social equality between the races, many Democrats hoped to persuade Union men to abandon the Republican Party or, at the very least, split the party into factions in order to "redeem" the state. The Virginia Free Press in Charles Town, Jefferson County, reported "Let us then be up and doing; let every union man opposed to negro suffrage, and consequent negro equality, come manfully forward and put his shoulders to the wheel. No state in the American Union suffers the wrongs and corruptions of West Virginia—aye, suffers almost in silence. ${ }^{54}$

Civil War and the debates over slavery and black suffrage in West Virginia splintered the population into numerous political factions. In 1868, candidates for office in Jefferson and Berkeley counties alone represented Liberal Republicans, Proscriptive Republicans, Independent Republicans, Conservative Democrats, Independents, and Radicals. ${ }^{55}$ Newspapers, regardless of party affiliation, that appeared benevolent and paternalistic toward African Americans

\footnotetext{
${ }^{51}$ Burke, “Storer College,”167-174.

52 Talbott, "Some Legislative and Legal Aspects," 85.

${ }^{53}$ South Branch Intelligence, October 9, 1868; and Talbott, "Some Legislative and Legal Aspects,” 86.

54 “Organization,” The Virginia Free Press, November 21, 1868.

${ }^{55}$ Virginia Free Press,
} 
immediately following the war, often became outspoken critics when the suffrage issue arose. ${ }^{56}$ Amid diverse racial attitudes and altering public opinion, African Americans often found it difficult to ascertain their status in the new state.

Few whites advocated black suffrage, including former unionists. ${ }^{57}$ The question of granting suffrage to African Americans in the state was not whether or not blacks should be allowed to vote, but why blacks should be allowed to vote when thousands of ex-Confederates and southern sympathizers in the state were disfranchised. Troubled by the deep divisions within the state and fearful of granting political power to citizens who aided the South, during the 1866 legislative session Gov. Boreman proposed an act requiring anyone challenged at polls to take a "test oath," swearing they had not voluntarily borne arms against the state. As a result, the legislature passed an amendment to the state constitution stating, "No person, who, since the first day of June, 1861, has given or shall give voluntary aid or assistance to the rebellion against the United States, shall be a citizen of this state or be allowed to vote at any election held therein, unless he has volunteered into the military or navel service of the United States and has been or shall be honorably discharged there from.” Following its ratification, the Democratic rallying cry for next five years was "The Radicals are enfranchising the Negro, while keeping thousands of their white neighbors from citizenship (voting)., ${ }^{58}$

Drastic postwar social changes that encompassed emancipation, a growing population of freedmen migrating to Harpers Ferry in need of the government services offered by the Freedmen's Bureau, the creation of black primary schools and Storer College by the Free Will Baptists from the North, and the rising debate over the suffrage issue, inflamed racial animosity and led to physical violence in Jefferson County in 1868. The Spirit of Jefferson reported that on

${ }^{56}$ Talbott, "Some Legislative and Legal Aspects," 58. 
July 11, 1868, two or three young white men sitting on boxes in front of Jacob B. Brown's store argued and exchanged blows with two black youths who were coming out of the store. After knocking one black boy down with a fist and hitting the other with a stone, the whites chased the two African American youths up the street toward Trussell \& Company. Stopping, the two black teenagers called for help and approximately thirty African Americans responded. The paper reported thirty blacks and only five or six whites engaged in the fighting until a truce was called while both sides went to get arms. Within a few hours, more than one hundred people were engaged in the fighting. Two men, Captain Brubaker of the Freedman's Bureau and Sheriff Potterfield of Harpers Ferry, arrived to stop the fighting. Although the white boys instigated the riot, locals were appalled that six or more whites sustained serious injuries. Both sides suffered crushed heads and bleeding faces. However, the sheriff only arrested the freedmen, including those who were injured, and charged them with rioting. Captain Brubaker claimed the sheriff "manifested the spirit in which law is administered in Jefferson County, arresting none but the colored.",59

The Winchester Times called the riot a "stupid drunken row” and the Spirit of Jefferson claimed that the riot could be traced to liquor, for "without it the Negroes never would have assumed the defiant attitude which they did, and which they maintained” until they aroused indignation. ${ }^{60}$ The paper maintained that blacks flocked into town on Saturday morning to celebrate the end of harvest and to spend the money they earned in the drinking houses, and in doing so, were "crazed by the influence of liquor, moving about the streets, with insolent airs, using abusive, obscene and profane language—naturally calculated to provoke a conflict, for

\footnotetext{
57 Talbott, “Some Legislative and Legal Aspects,” 90-92.

${ }^{58}$ Morgantown Post, July 28, 1866, as quoted in Talbott, "Some Legislative and Legal Aspects,” 94.

${ }^{59}$ Wynne, "Reconstruction and the Negro," 30-32.

${ }^{60}$ Wynne, "Reconstruction and the Negro," 30-32.
} 
however the case may be elsewhere, this community is not yet ready for submission to Negro insolence.”61 The editor of the Virginia Free Press asserted that whites involved in the riot should be supported "in their endeavors to maintain supremacy” instead of labeled as drunken rioters. Of course, James Gallagher, Jr., the editor's son, was one of those who instigated the riot. $^{62}$

Following five years of Republican rule and three years after the Civil War, the status of African Americans in West Virginia was still uncertain. By 1868, black West Virginians were free to leave the state and return, congregate without restriction, serve in segregated militia companies, and provided with an education if they were under the age of twenty-one. Legally, African Americans were tried and punished in the same method as whites and could testify against whites in a court of law. Despite these laws, blacks were still discriminated against both legally and extra-legally. Forbidden by law and strictly enforced, black West Virginians could not vote, hold office, serve on juries, or attend the same schools as whites. ${ }^{63}$

However, on March 3, 1869, West Virginia became the second state to ratify the Fifteenth Amendment to the United States Constitution granting African Americans the right to vote; six days after Congress proposed it and before it was officially submitted to the states. ${ }^{64}$ In the past, African American calls for enfranchisement had little influence on political officials or public opinion. Blacks in Parkersburg, West Virginia, petitioned the legislature for suffrage, citing their service during the war, as early as March of 1867. However, after William B. Stevenson, the next governor, introduced the petition to the legislature, it was tabled on his motion. ${ }^{65}$ While Democrats exploited the suffrage issue in the hope of dividing the Republican Party, Republicans

\footnotetext{
${ }^{61}$ Wynne, "Reconstruction and the Negro," 30-32.

62 Wynne, "Reconstruction and the Negro," 30-32.

63 Talbott, "Some Legislative and Legal Aspects,” 66.

64 Talbott, “Some Legislative and Legal Aspects,” 87.
} 
attempted to avoid the issue in campaigns. However, the growing controversy over the continued disfranchisement of whites further divided the already fractured Republican Party and led to heightened compassion over the plight of 25,000 disfranchised Democrats. ${ }^{66}$

When Governor Stevenson addressed the legislature in January of 1870, he proposed the removal of political restrictions placed on former Confederates. Hoping to halt the growth of the Democratic Party, Liberal Republicans (also called Let Ups) William H.H. Flick and Daniel Lamb proposed an amendment to the West Virginia Constitution giving all men over the age of twenty-one the right to vote, African Americans as well as former rebels. ${ }^{67}$ Despite Democratic attempts to change the wording to provide for white suffrage only, the legislature approved the basic tenets of the Flick Amendment on Feb. 25, 1870. However, that same legislature also refused to require Negro suffrage in Lewisburg as well as to remove the term "white" as a qualification for jury duty. ${ }^{68}$

Under federal law, black West Virginians went to the polls for the first time to vote in municipal elections held in Clarksburg and Weston in May of $1870{ }^{69}$ Throughout the spring and summer, prominent African Americans and whites gave addresses and set up meetings designed to inform African American voters of their rights and responsibilities. In the eastern panhandle, Professor T.J. Ferguson, principle of the black school in Parkersburg, delivered an address in

\footnotetext{
${ }^{65}$ Talbott, "Some Legislative and Legal Aspects," 97.

${ }^{66}$ Otis T. Rice, West Virginia: A History (Lexington: The University Press of Kentucky, 1985), 159-161.

${ }^{67}$ Otis T. Rice, West Virginia, 159-161 . Flick was born in Ohio in 1851. After serving in the Civil War, he attended Cleveland Law School then moved to Moorefield, West Virginia in 1867 then to Franklin in Pendleton County. Elected to legislature in 1868 and 1870, he was the author Flick Amendment which enfranchised ex-Confederates and abolished test oaths and civil limitations. He served as Prosecuting Attorney of Pendleton 1869, Grant County in 1872, and Pendleton County in 1873. In 1874, he moved to Martinsburg where he became the Prosecuting Attorney in 1880, but resigned in 1882 to become the U.S. District Attorney for West Virginia under President Arthur. In 1876 he was the Republican candidate for Judge of the Supreme Court of Appeals of West Virginia. In 1880 and 1888 he was the Republican candidate for Congress in $2^{\text {nd }}$ District vs. William L. Wilson. Flick died in 1904, See History of West Virginia Old and New Vol. II. Chicago and N.Y. American Historical Society, 1923, 346.

${ }^{68}$ Talbott, "Some Legislative and Legal Aspects," 187.

${ }^{69}$ Sheeler, "The Negro in West Virginia," 196.
} 
Martinsburg, Berkeley County, advising blacks of their duty and telling them to "always be true and loyal to the government and the old flag." ${ }^{\text {,70 }}$ African Americans in Jefferson County met at the Baptist Church in Charlestown to listen to addresses from Andrew Hunter, prosecutor in the John Brown trial, and William H. Travers, who advised them of their general duties as citizens. Hunter and Travers, both Democrats, beseeched black West Virginians to intelligently exercise their rights and privileges and cautioned them against designing men who would court them for their power, use them, and then cast them off. The two men also denounced attempts to create hostility between the races and called for amicable relations. ${ }^{71}$

That summer, delegates to both the Democrat and Republican state conventions debated the Flick Amendment. The debates were irrelevant for the Fifteenth Amendment to the United States Constitution overrode existing state laws, and African Americans in West Virginia legally held the franchise. However, the cultural restrictions remained. When twenty African Americans attended the State Republican Convention held in Parkersburg in June of 1870, the Swann House refused to give them rooms, forcing the black constituents to stay across the Ohio River in Belpre, Ohio. At the convention, the delegates did not nominate any African Americans for office. ${ }^{72}$ Despite their exclusion from prominent positions within the Republican Party, most African Americans in West Virginia remained loyal to the party, attending local conventions and working diligently to elect white Republicans who were running for office. In response to Democratic charges that African Americans were illiterate and ignorant of public policy, the Wheeling

\footnotetext{
${ }^{70}$ Parkersburg State Journal, May 12, 1970.

71 “A Meeting of Colored Citizens,” Virginia Free Press, June 4, 1870; Hunter was born in Berkeley County and lived in Charles Town, Jefferson County. Originally a Whig, Hunter was a member of the 1850 Virginia Constitutional Convention and close friend of General Robert E. Lee. During the Civil War, Union troops burned his home in Charles Town and held Hunter in custody for a month, although there were no charges filed against him. Millard Kessler Bushong, A History of Jefferson County West Virginia (Charles Town: Jefferson Publishing Company, 1941), 293-294.

72 “Amalgamation Convention,” Wheeling Register ; “Radical Convention,” Virginia Free Press, July 3, 1870.
} 
Intelligencer summed up the relationship between blacks and the Republican Party when it argued that African Americans were intelligent enough to know that voting for Democrats was voting for disfranchisement and, therefore, blacks “almost universally vote the Republican ticket. ${ }^{73}$

Although Berkeley and Jefferson counties contained the largest concentration of black voters in West Virginia, southern Democrats dominated in both counties. ${ }^{74}$ African Americans constituted the largest number of the minority Republican Party in these counties, yet scalawags, native white Republicans who recognized the rights of blacks, but who wanted to keep control of local and state government away from both blacks and former rebels, dominated the leadership of the local Republican parties. ${ }^{75}$ For African Americans, however, loyalty to the Republican Party did not mean complacency, and blacks quickly expressed their disappointment of party leaders and their failure to advance the interests of black constituents. In October of 1870, African American George McKinney announced he was running as the Independent Republican Union candidate to represent Jefferson County in the House of Delegates. The Virginia Free Press commented, "He has observed, doubtless, that the sympathy of the Republican Party for the colored 'man and brother' is but a shallow pretense—-that their love for the newly enfranchised only extends to him as a voter. In all their nominations they ignore the claims of the colored man to positions of emolument—he is the slave to the Republican Party, 'a hewer of wood and drawer of water." According to the Press, McKinney was "testing the professions of those white lovers of the ebony hue. He asks for their votes. Will he get them?”76

Both McKinney and the Republican Party were disappointed in the fall election.

\footnotetext{
73 “Sour Grapes,” Wheeling Intelligencer, October 15, 1870.

${ }^{74}$ Talbott, “Some Legislative and Legal Aspects,” 114.

75 “Buckwheat Faced Republicans,” Pioneer Press, September 1886.

76 “A Colored Aspirant, “Virginia Free Press, October 8, 1870.
} 
Exasperated by the actions of the radical Republicans, many West Virginians turned away from the Republican extremists, leaving Democrats to take control of the state on a platform that appealed to race prejudice. ${ }^{77}$ Not only did Democratic candidate John J. Jacobs defeat the incumbent Republican, Governor Stevenson, the Democrats won a majority in both Senate and the House of Delegates. ${ }^{78}$

Legislators once again addressed the Flick Amendment in the 1871 session and submitted it to the citizens of West Virginia, who voted 23,546 to 6,323 in favor of the amendment to the state constitution in April of $1871{ }^{79}$ The Wheeling Daily Intelligencer reported a low voter turnout for the election and explained it by stating that "it contained features displeasing to a very large number of both parties” and "required an unpleasant concession from each;” it required the “Democrat to concede Negro suffrage, and the Republican [to concede] ex-rebel suffrage."80 The Intelligencer reported that, in truth, the "only substantial question involved in the amendment is that of enfranchising ex-Confederates" since the black man "is a voter now, and will continue to be, whether our state constitution is amended or not." ${ }^{\text {,81 }}$

In areas where a strong southern sentiment existed and a greater number of large African Americans resided, such as Berkeley and Jefferson Counties, conservative whites remained intensely hostile to Republican extremists. The Spirit of Jefferson reported, “The radical party in this county is driven to desperation, in its effort to retain even a medium of that power which of late years has robbed, tyrannized and persecuted its people. Chagrinned and discomfited by the withdrawal of all the more respectable candidates presented by the 'black and tan' convention at Harpers Ferry, its leaders have been beating the bushes in all directions to bring about a fusion by

\footnotetext{
${ }^{77}$ Sheeler, “The Negro in West Virginia,” 198.

${ }^{78}$ Rice, West Virginia History, 159-161.

${ }^{79}$ Rice, West Virginia History, 160-161.

80 “Yesterday’s Election,” Wheeling Daily Intelligencer, April 28, 1871.
} 
which they hope to cajole the unwary and by possibility steal some of its loyal devotees into place and power.”82 It also claimed that citizens of Jefferson and Berkeley counties lived in a “political, civil, financial, and generally deranged condition” due to the “cowardly, insulting, thieving partisan, yea, villainous conduct of the radical party in this State, from the highest to the lowest," and that "No two counties in the State have been more outraged and persecuted by Radical rule, and it should be a matter of general rejoicing that the day of their deliverance has at length come." 83

Gaining power, Democratic legislators called for a new constitutional convention to eliminate the "last vestiges of Radical Republican rule” in the state. Voters agreed, voting 30,220 to 27, 658 in approval. Held in January of 1872, there were sixty-six Democratic delegates in attendance and only twelve Republicans. ${ }^{84}$ No African Americans participated in the constitutional convention, and several attempts were made to disfranchise blacks in the state regardless of federal law. However, other Democrats, under the leadership of Charles J. Faulkner of Martinsburg, favored black suffrage. Eventually, the delegates passed an act placing the state constitution in agreement with the Fifteenth Amendment of the United States Constitution, thereby ensuring the franchise for African Americans in the state, and established another law granting blacks the privilege of holding office. ${ }^{85}$

On Saturday, February 24, 1872, Charles Arter and James Warfield presented a petition to

\footnotetext{
81 “The Question To Be Voted On Today,” Wheeling Daily Intelligence, April 27, 1871.

82 “Another Dodge," Spirit of Jefferson, October 24, 1871; “West Virginia Election: Jefferson County Repudiates Radicalism by Over 700 Majority,” Spirit of Jefferson, October 31, 1871.

83 "Awake to duty," Spirit of Jefferson, October 24, 1871.

${ }^{84}$ Rice, West Virginia History, 161-162.

${ }^{85}$ Sheeler, “The Negro in West Virginia,” 200-202. Delegates knew federal law took precedence over state law in the question of black suffrage and when southern states did disfranchise African American voters at the end of the nineteenth century, they did not deny blacks the right to vote in opposition to federal law. Instead, they enacted restrictions that eliminated the majority of black citizens from voting or employed extra-legal means such as violence. As for the act giving African Americans the right to hold office, delegates to the convention knew blacks were the minority in every county and had little chance of electing any African Americans to office.
} 
the Constitutional Convention from sixty-four African Americans (although the Journal of the Constitutional Convention describes the group as "free persons of color") in Jefferson County who wanted the Constitution amended to allow black West Virginians to serve on juries. ${ }^{86}$ After passing the petition on to the Committee on Bill of Rights, committee members ruled on March $13^{\text {th }}$, "it is inexpedient to incorporate in the Constitution any provision fixing the qualification of jurors, or proscribing the manner of their appointment" and that the "Legislature should be left free to enact such laws. ${ }^{, 87}$ However, less than a month after the convention adjourned, an event occurred in Wheeling that removed the decision on whether or not black men could serve as jurors out of the state's control and into the hands of the United States Supreme Court. On April 28, 1872, a young, African American carpenter named Taylor Strauder murdered his wife, who was well-known for her constant affairs. Tried, convicted, and sentenced to hang in January of 1875, Strauder petitioned the court to send his case to federal court on the grounds that he could not receive a fair trial in the state and that state law excluding all blacks from jury service denied him "equal protection of the law" as guaranteed by the Fourteenth Amendment. ${ }^{88}$ Clifford, who resided in Wheeling at the time of the trial, had no way of knowing that the Strauder case and struggle to empanel blacks in West Virginia would one day have an impact on him. ${ }^{88}$

Like all black West Virginians, Clifford witnessed and experienced the racial discord and civil violations inherent in the transformation of a slave society to a free state and the cultural changes that ensued. In Wheeling, which Clifford referred to as "the city of our [Clifford's] early manhood," rowdy whites frequently disrupted African American religious services or attacked and beat black parishioners as they left their places of worship in the post-war years. They threw bricks through the windows at City Hall where meetings were being held. In June of 1868, a

${ }^{86}$ Preston, John J.D, Journal of Constitutional Convention (Charleston: Henry S. Walker, 1872), 120. 
conductor forced an African American passenger on a street car to ride outside on the platform, claiming "it was contrary to the rules of the company for Negroes to ride inside." ${ }^{\text {,99 }}$ The next year, in one of the first civil rights cases in West Virginia, Henry Hollinger sued the Citizen’s Railway Company in Wheeling for two thousand dollars in damages after the railway conductor ordered him to the platform following a dispute with a white passenger who protested his presence. When the case went to the circuit court in March of 1870, the jury ruled in favor of Hollinger. However, the jury expressed its opinion of the case by awarding Hollinger the grand sum of ten cents. ${ }^{90}$ In May, officials invited African Americans in Wheeling to participate in the Decoration Day [Memorial Day] parade to honor the soldiers who died in the Civil War. Originally instructed to march in the rear of the procession of soldiers and citizens, organizers then moved blacks to the rear of the carriages carrying the Mayor and invited guests. However, when the procession began to move, officials told the black participants they were to march at the end of the procession, behind forty to fifty carriages. Indignant, the African Americans threw down their flowers and bouquets and refused to march. In a letter to the Wheeling Intelligencer, "A Colored Citizen” wrote that although it was not a partisan celebration, the majority of the organizers were influential Republicans and that the Republican Party should not assume that blacks would continue to sustain the party despite any "amount of insult and contumely that may be heaped upon them." ${ }^{91}$ Although his name is not mentioned in the article, Clifford later suggested his presence when he later wrote "in processions, behind is his place" in an article on "the Negro's

\footnotetext{
${ }^{87}$ Preston, Journal of Constitutional Convention, 160.

${ }^{88}$ Talbott, "Some Legislative and Legal Aspects," 181-182.

${ }^{89}$ Talbott, "Some Legislative and Legal Aspects,” 58-59; Pioneer Press, May 15, 1915.

90 Talbott, "Some Legislative and Legal Aspects," 59-60. Henry Hollinger, the son of Henry and Minty Hollinger, was thirty-nine years old when the case occurred. Clifford was friends with the Hollingers and Henry's younger brother, George, would later serve as one of Clifford's co-editors at the Pioneer Press.

91 “The Colored Men and the Procession,” Wheeling Daily Intelligencer, June 4, 1870.
} 
place” in the pages of the Pioneer Press. ${ }^{92}$ Despite the racial friction incurred by rapid social change, the legal status of African Americans in Clifford's home state continued to improve, providing opportunities for black West Virginians that were unavailable elsewhere in the south. ${ }^{93}$ However, the quantity and intensity of racial hostility varied throughout the state and no where was it more trenchant than in the eastern panhandle counties of Berkeley and Jefferson.

Believing that man's "true dignity begins in the mind" and is "the source of all that is great in him,” Clifford moved to Harpers Ferry in Jefferson County to attend Storer College in the fall of $1873 .^{94}$ In its early years, admission required students to "give satisfactory evidence of good moral character," and offered an education to those who were "ladies and gentlemen.” The school maintained established codes of conduct complete with educational and social prohibitions that included "no attendance at balls, dances, or parties without permission" and only on weekends, no visiting drinking saloons or imbibing of "intoxicating liquors," no using "profane or indecent language,” no card playing, jumping, dancing or fighting in buildings, and no smoking on the school grounds or public streets. ${ }^{95}$ The self-discipline and moral values instilled in students of Storer College became a part of Clifford's life; and the values he practiced, were demanded of others.

He also learned how precarious life could be, particularly in that region. That same fall, on October 6, 1873, the sheriff arrested and charged John Taliaferro with attempted rape and the murder of Anna Butler near Falling Waters in nearby Berkeley County. Aware of the deep racial tensions in the region, Taliaferro's lawyers submitted a motion to remove the case to the United

\footnotetext{
92 “The Negro in His Place,” Pioneer Press, November 30, 1888.

${ }^{93}$ Joe William Trotter, Coal, Class, and Color: Blacks in Southern West Virginia, 1915-32 (Urbana: University of Illinois Press, 1990), 265-266; and Pioneer Press, May 30, 1914. The only legal segregation in West Virginia occurred in schools and marriage. The 1872 West Virginia Constitution forbade integrated schools in the state. ${ }^{94}$ Clifford, "Annual Address."

${ }^{95}$ Burke, “Storer College," 206-209.
} 
States District Court instead of the Berkeley County Circuit Court, stating that a trial held in Berkeley County would violate the Thirteenth and Fourteenth Amendments to the United States Constitution as well as the Civil Rights Act of 1866. Judge Hoge denied the motion. The lawyers then moved for a change of venue based on the affidavits of Taliaferro, Charles Keefer, and A.B. Shutt, and one signed by blacks living in the county stating that blacks could not receive a fair trial in Berkeley County. In response, prominent white citizens presented an affidavit to the court claiming there was no reason for change. Judge Hoge denied the motion for change of venue. The Martinsburg Statesman, a Democratic paper, claimed that the defense lawyers did not have to "thrust forward federal power and its unwarrantable interference with the laws of a sovereign” for the Thirteen and Fourteenth amendments nor the Civil Rights Bill of 1866 conferred "no superior rights upon the negro over the white man" and that raising the question at all was "harmful in its influence on the credulous and ignorant negroes in attendance, and a seeming license to unbridled passions."96

According to reports, Taliaferro's first trial ended with a hung jury. ${ }^{97}$ Eventually convicted and sentenced to death on July 31, 1874, the prisoner made no comment other than to say "No Sir" when asked if he had anything to say; yet the Martinsburg Statesman described his manner as "defiant." " However, the Court of Appeals ruled there was an error in the prosecution and sent the case to another term, creating widespread belief that Taliaferro would escape the punishment he deserved. Residents feared long delays in the legal system would make conviction impossible, encouraging others to rape and murder. ${ }^{99}$ The outraged Martinsburg Statesman declared the interference of the Court of Appeals "had placed every female in the county of

\footnotetext{
${ }^{96}$ Martinsburg Statesman, May 19, 1874. The name Taliaferro or Taliafero is pronounced as Tolliver and newspapers printed it both ways and occasionally as Tolliver.

97 “'The Martinsburg Lynching,” Baltimore American and Commercial Advertiser, August 15, 1874.

${ }^{98}$ Martinsburg Statesman, June 2, 1874.
} 
Berkeley at the peril of the unrestrained lusts of the vicious.”100

Citizens found those fears substantiated the second week of August when the sheriff arrested another man, Henry Johnson, for assault on a young girl. Just days after Johnson's arrest, local whites decided to take matters in their own hands. On August 13, 1874, several hundred people gathered on the street outside the jailhouse under the leadership of a man referred to as "the Colonel.” Three hundred men, two hundred on horseback and one hundred on foot, carrying pistols and sabers appeared at the jailhouse. Jailors reported that "unrecognized” persons pulled Taliaferro from the jail and took him one mile north of town to the intersection of the Hedgesville Road and the Williamsport Turnpike. After tying a rope to a locust tree, horsemen formed a circle thirty feet deep around Taliaferro, gave the prisoner ten minutes to pray; spent five minutes to prepare for the execution, and soon "all that was mortal of John Taliaferro dangled between earth and sky.”101

The Martinsburg Statesman reported Taliaferro “prayed earnestly for forgiveness, but made no direct confession of guilt," and claimed either he did not believe they would lynch him or had made up his mind to proclaim his innocence until the last moment. The Baltimore American maintained the "poor wretch protested innocence and begged for mercy to the last moment” and printed Taliaferro’s prayer, as heard by a participant and repeated to the editor, in the newspaper. In reply, the Martinsburg Statesman said it was certain that no one who was near enough to hear what Taliaferro said would be foolish enough to repeat it to a stranger. The Statesman also reported that the lynching seemed "not to have been marked by violence or excitement." The newspaper asserted that "enough is known of those who have thus executed the

\footnotetext{
99 “The Hanging of Toliver,” Martinsburg Statesman, August 18, 1874.

100 “A Vile Slander,” Martinsburg Statesman, August 25, 1874.

101 “The Hanging of Toliver,” Martinsburg Statesman, August 18, 1874; “The Martinsburg Lynching,” Baltimore American . The papers reported the lynching occurred at Cumberland Valley Railroad on Williamsport Pike or
} 
sentence of the law to leave no doubt of the fact that their organization was independent of party bias or prejudice. Southern men and Northern men—Confederate and Union Soldiers—

Democrats and Republicans—-were undoubtedly united in the accomplishment of the result.”102 Although citizens knew who participated in the lynching, a jury of inquest into Taliaferro's death reported that "John Talvaferro to his death at the hands of an organized band of men, unknown to the jury.”103 Regardless of whether John Taliaferro was guilty or not, his lynching accentuated the need for African Americans to obtain full civil and political rights. Clifford came to believe that, as a group, "people who do not contend for their rights can not expect to get them, or if gotten, cannot expect to retain them" and that cowardice "induces silly fellows to do you harm" and makes men "subject to so many injustices."104 Clifford fully intended to assert his rights, not only as a man ... but for his race as well.

After graduating from the Storer College Normal School in the spring of 1875, Clifford became the first black principal of the Sumner School in Martinsburg, West Virginia, the school Annie Dudley founded in 1868. On December 28, 1876 Clifford married fellow Storer graduate Mary E. Franklin in a ceremony performed by Professor Nathan Brackett at Harpers Ferry. Born in Lexington, Virginia, Mary was the daughter of Albert Barbour Franklin and Mary Elizabeth Edmonson Franklin. Clifford was twenty-eight years old; his bride was seventeen. ${ }^{105}$ It was a loving marriage that lasted for fifty-six years and produced eleven children: Albert, 1877; Maude, 1879; J. Paul, 1882; Coralie, 1884; Helen, 1885; William H., 1887; Mary, 1887; Laura,

\footnotetext{
Warm Spring Road as well as the location indicated above.

102 "The Hanging of Toliver;” "The Martinsburg Lynching."

103 "The Hanging of Toliver;” "The Martinsburg Lynching.” The jury of inquest included Frank Patterson, George F. Rutherford, Dr. J. Johnson, J.H. Gettinger, Thomas Collins, Jas. H. McSherry, S.P. Douglass, J.A. Blondel, D.C. Byers, D.M. Shaffer, Thomas Rusler, and John T. Janney.

104 “Editor Clifford’s Opinion,” Pioneer Press, May 27, 1911; and “Don’t Be Scared,” Pioneer Press, January 28, 1910.

${ }^{105}$ Paul Clifford Address, PMWCP, 17.
} 
1890; John Robert, Jr., 1893; Dorothy, 1899; and a stillborn child in $1902 .{ }^{106}$ Clifford bought a home on West Martin Street next to the Sumner School and attended the nearby Mt. Zion Methodist Episcopal Church where he was superintendent. ${ }^{107}$

Although Clifford became involved in Republican Party politics immediately after his return to West Virginia in 1868, throughout the 1870s he became more active, spending his "time and means" campaigning throughout the state for Republicans. ${ }^{108}$ In particular, Clifford frequently campaigned for William H.H. Flick, author of the Flick Amendment, when he was the Republican candidate for the West Virginia Supreme Court of Appeals in 1876 and in 1880 when he ran for the United States Congress. ${ }^{109}$ Clifford and Flick knew each other as boys and were friends, at least as much as they could be with "one, of course, always having a place." ${ }^{\text {"110 }}$ In addition to Clifford, there were numerous other black West Virginians who participated in politics. In March of 1876, many of those men held the first black convention in the state. Robert W. Simmons, the dominating force behind the establishment of the black school in Parkersburg served as chairman. During the proceedings, the delegates established a state executive committee and chose delegates to represent West Virginia at the National Convention of Colored Men to be held in Nashville, Tennessee, under the leadership of Fredrick Douglass.

\footnotetext{
${ }^{106}$ Rosemary Clifford, “J.R. Clifford Genealogy,” RCMP.

${ }^{107}$ Clifford bought his first lot from Samuel Light in February of 1878 for $\$ 135.00$. This property, as well as any other property Clifford purchased during his lifetime, was in his wife Mary's name. Clearly, Clifford recognized the danger of being an educated and aspiring black man who was in the process of acquiring property and making social, economic, and political gains. If any attempts to economically ruin him (through lawsuits) or physically harm him occurred, May would be able to retain all of the property as the legal owner. Deed Book 74, 313; Deed Book 98, 491; Deed Book 106, 259; Deed Book 110, 343; and Deed Book 107, 102, Berkeley County Clerk’s Office, Berkeley County Court House, Martinsburg, West Virginia (hereafter recorded as BCCO). Mt. Zion Methodist Episcopal Church formed in 1866 with eighteen members between Race and Martin Streets, north of the schoolhouse. In 1868, the congregation erected a church on the west end of Martin Street and built the present church in May of 1882. Early pastors included Rev. J. Bowman, John Mayberry, John Hughes, E. Hammond, P. McPherson, John A. Holmes, W.H. Kennedy and G.R. Williams. West Virginia Encyclopedia,

108 “Independent in Politics," Pioneer Press, September 1886.

${ }^{109}$ The American Historical Society, Inc., History of West Virginia Old and New and West Virginia Biography Vol. II (Chicago: The American Historical Society, Inc., 1923), 346.
} 
Delegates chosen included W.F. Gaskins, Ohio County; T.J. Owens, Wood County; Alfred Meade, Marion County; and Charles Ankrum of Harrison County. ${ }^{111}$ That May, delegates to the Republican State Convention also elected Robert W. Simmons to serve as a delegate at large to the National Republican Convention, making him the first black West Virginian to do so. ${ }^{112}$ Although it is unknown if Clifford attended the West Virginia Colored Convention, later on he reported that “when the brave and brainy 'old man eloquent,' Robt. W. Simmons, Geo. T. Jones, and other able men organized a 'State Executive Committee,' I was antagonistic to it. Now I see its wisdom." ${ }^{113}$ Certainly, he knew the men who participated. Within a decade, three of the men who attended the conference, George W. Hollinger, George T. Jones, and Joseph L. Champ, would join Clifford as co-editors of the first black newspaper in the state, the Pioneer Press.

Although the majority of African Americans in the state were Republican, black Democrats were active as well. When the Reverend J.W. Dunjee of Winchester, Virginia, came to speak in Martinsburg that same year, Clifford claimed he was the first "Negro" Democrat he had ever seen. Clifford offered to find him a place to speak and to protect him. Clifford knew that local blacks, who were fiercely Republican, would be hostile to Dunjee. Armed with stones and clubs, Clifford and a few friends defied over fifty African Americans who threatened to attack Dunjee. He later took him to the home of a prominent white, Judge Charles J. Faulkner, for protection. Clifford maintained that all men should be allowed to speak and offered to debate

\footnotetext{
110 “Flick vs. Clifford, Pioneer Press, October 1886.

111 Pioneer Press September 1886; and “Proceedings of Tuesday’s Convention of West Virginia Colored Men,” Wheeling Daily Intelligencer, March 9, 1876. Simmons was a barber in Parkersburg. W.F. Gaskins was the principle of the grammar school in Wheeling. John W. West served as the first principle at the black school in Wheeling from 1866 to 1871. A.B. Wilson then served as principle for one year before W.F. Gaskins took the position. Rev. G.W. Hollinger also was from Wheeling. George T. Jones was a teacher at Weston and J.L. Champ, who was from Mt. Pleasant, Ohio, later became the principle at Parkersburg, West Virginia.

${ }^{112}$ West Virginia Tribune (Keyser), May 20, 1876.

${ }^{113}$ Pioneer Press, September 1886.
} 
Dunjee publicly if the black community would give him a proper hearing. ${ }^{114}$ Unfortunately, numerous members of the black community saw Clifford's defense of Dunjee as disloyalty to the Republican Party.

Clifford was becoming more critical of the party and its failure to advance the interests of African Americans, a prevailing standard in the eastern panhandle. Much of his opinion stemmed from his growing involvement with prominent blacks from outside the state, such as John W. Cromwell, editor of the People's Advocate in Washington, D.C., and an outspoken critic of Republican Party politics. Clifford met Cromwell at the Teacher’s Institute and Educational Convention held at Harpers Ferry in the summer of 1877. Cromwell described the young teacher as a "central figure” who was "chivalric in bearing.”"115 Cromwell quickly became a friend as well as a key influence in Clifford’s life.

Within the political realm, class and ideological divisions were emerging within the black community in the nation and in the state. Locally, Clifford often referred to "a lower class of blacks,” mostly uneducated, whose blind loyalty to Republican Party leaders stemmed from material expediency rather than political or moral principles. Others were willing to work within the community mores, accepting social and political discrimination in exchange for past benefits bestowed upon them by the Republican Party. Clifford, on the other hand, expected results from the Republican Party and chastised local party leaders when they did not adhere to the original principles of the party. ${ }^{116}$ By 1878, Clifford's outspoken behavior and refusal to accept discrimination in any form, led Reverend H.E. Keyes, the minister of the Dudley Baptist Church,

\footnotetext{
${ }^{114}$ Pioneer Press, November 16, 1912.

115 “Communications,” Journal of Negro History, Vol. 8 No. 3 (July 1923): 338.

116 "Winchester Rifles in Arkansas, Poison Secret Intentional Murder in Berkeley County,” Pioneer Press, August 1888.
} 
to label him an infidel from the church pulpit. ${ }^{117}$

Among political leaders, Clifford greatly admired and respected Fredrick Douglass. After listening to a speech Douglass gave in Martinsburg on August 10, 1879, Clifford called him "an intellectual giant who could prove blacks as intelligent as whites.”118 However, in a letter to John Cromwell's People's Advocate, he criticized the response of the black masses to Douglass' speech, stating that while the whites treated Douglass kindly, the blacks did not. Disparagingly Clifford wrote, "While he was speaking upon a sandy foundation, beneath an unclouded sky, our young gents and ladies preferred to dance two hundred yards from him, and inside of Floral Hall, on Fair Ground, the 'old folks' made so much noise devouring chicken and rattling dishes that one could scarcely hear what the good man was saying. He did not forget to tell them that they were more anxious to fill the lower than upper cavities."

That same year, the court gave black West Virginians a civil rights victory. Seven years after Taylor Strauder's murder trial in Wheeling, the United States Supreme Court case Strauder v. West Virginia gave African Americans the legal right to serve on juries. The indignant Martinsburg Statesman maintained:

The magistrates of the several counties of this State in selecting juries hereafter, will have to conform to the edict of that thoroughly radicalized body, misnamed a Supreme Court. No matter what the constitution or laws of the State may be, or how besottedly ignorant the Negroes are as to the duties required of them, the justices must select them in equal proportion to the number they bear to the whole population. And yet we have a political organization, so-called republican in character, who is making ready to enter upon a canvas before the intelligent people of this State, who will be obliged to sustain this foul blotch upon its fair escutcheon. ${ }^{120}$

Despite the court's ruling, African Americans were not called to jury duty in West Virginia.

\footnotetext{
${ }^{117}$ Pioneer Press, May 29, 1915. Keyes was originally the pastor at the Shepherdstown Baptist Church. He then went to Dudley Chapel, a Freewill Baptist Church in Martinsburg. Erected in 1868 on Raleigh St. between Martin and Burke for \$8,000, its early pastors included Rev. J.E. Burrell, W.P. Fisher, and Keyes.

${ }^{118}$ People's Advocate, August 23, 1879.

${ }^{119}$ People's Advocate, August 23, 1879.
} 
Clifford referred to the "oversight" as a mystery, asking "Why is it, the colored citizens are never missed by the assessors, and are always found by the Sheriffs, or to pay taxes, and are never found to act as jurors?"121

Meanwhile, a growing number of African Americans began to express their dissatisfaction with the Republican Party. In 1881, blacks identified as “independent colored voters" held a meeting at the Martinsburg courthouse in Berkeley County. The Martinsburg Independent reported that the meeting was well attended because it was "quite a novelty to hear colored orators on the political rostrum," and that the speeches contained "nothing offensive." Officers attending the meeting included Chairman James Johnson and Secretary William Swartz. William Ford and Charles Smith gave speeches as well as H.E. Keyes, a candidate for the House of Delegates, who "gave an excellent, conservative, and eloquent address."122

Although the article in the Martinsburg Independent indicated some whites were willing to tolerate or accept black leadership, many whites in the region were not. When Fredrick Douglass returned that year to Harpers Ferry to raise funds for a John Brown Professorship at Storer College, he did not get a favorable reception. Andrew Hunter, John Brown’s prosecutor, asserted that Douglass would not be allowed to speak in Jefferson County and if he tried, Hunter would “meet him, denounce him, and crush him.” Hunter traveled to Harpers Ferry where he followed Douglass to the platform and sat down beside him uninvited. However, Douglass went on to deliver a great speech and as he returned to his seat, Hunter shook hands with Douglass and said "now let us go on."123

\footnotetext{
${ }^{120}$ Martinsburg Statesman, March 11, 1880.

${ }^{121}$ Pioneer Press, November 30, 1888.

${ }^{122}$ Martinsburg Independent, February 19, 1881; Martinsburg Statesman, February 17, 1881.

123 “Communications,” 338-339. Hunter tried to find evidence that Douglass conspired with John Brown in an effort to try Douglass at the same time. Clifford reported that Hunter lived long enough after Brown to come to the conclusion "there was more divinity than fanaticism in Brown's actions.” Hunter died 20 November 1888. "John
} 
During these years, Clifford began to form ties to national organizations as well as national leaders. Clifford's friendship with John W. Cromwell led to membership in the Knights of Wise Men, an organization headquartered in Nashville, Tennessee. Membership in this organization gave Clifford the opportunity to discuss the inequality blacks faced in America with prominent African Americans throughout the country. Members included men such as Cromwell, John R. Lynch of Mississippi, William J. Simmons from Kentucky, Robert Peel Brooks of Virginia, Frances L. Cardozo of Washington, D.C., and the radical and controversial Bishop Henry McNeal Turner. In 1882, Clifford attended the Knights of the Wise Men convention held in Atlanta, Georgia, where he delivered a "masterly" keynote address to both members and state officials, including Georgia’s Governor Alfred H. Colquitt, at the State Capitol. In appreciation of his eloquent speech, members presented Clifford with a gold-headed cane engraved with the name of the convention and his initials. ${ }^{124}$

In 1882 Clifford started his own paper, becoming the proprietor and editor of the Pioneer Press in Martinsburg. Clifford printed the Pioneer Press in the offices of the Martinsburg Independent, owned and operated by a prominent white Martinsburg attorney, J. Nelson Wisner. Published monthly, at a rate of seventy-five cents per year, Clifford advertised the Pioneer Press as a Republican newspaper intended to inform and educate African Americans under the banner of "Ballots in Time of Peace, Bullets in Time of War." The creation of the Pioneer Press provided Clifford with a voice throughout West Virginia and beyond; raising him to prominence, while instilling fear in those who increasingly viewed him as a political threat. ${ }^{125}$

The events that shaped John R. Clifford's life to this point, his heritage and status as a free African American, the experiences he had as a soldier and the education he had acquired, his

Brown’s Prosecuting Attorney,” Pioneer Press, November 30, 1888. 
witnessing of John Tollifero's lynching and his desire for equal justice, formed both the man and his character. Those events, and the people he met along the way ... those who would help him in his quest for equality, and those who would fight against him, would determine his actions for the next fifty years.

124 “Communications,” 338-341.

${ }^{125}$ Pioneer Press, August 1885. 


\section{CHAPTER TWO}

\section{"DOUGH-FACED, BREAD AND BUTTER POLITICIANS:"}

The Road to Independence

"An enemy is not the worst thing in the world. He reminds you of your faults, even if he does multiply them, and praises you only when you are dead. Many men have been made to do good work because their enemies were watching them to find fault. To have them is no bad sign. People who drift with the tide and time have none."

When Republican President Rutherford B. Hayes ended Reconstruction with the Compromise of 1877, eliminating federal protection in order to capture the presidency, many blacks in America viewed it as a symbol of their abandonment by the Republican Party. ${ }^{2}$ Disheartened, those African Americans expressed their disappointment with Republican Party politics. In Martinsburg, black West Virginians frustrated with the local Republican leadership formed an "independent” party in 1881. However, the most vocal opposition to Republican Party politics came from John R. Clifford's Pioneer Press. Clifford's opposition to local Republican leaders, his vocal demands for political, economic, and social equality for African Americans, and his refusal to "accommodate" white politicians resulted, not only in his exclusion from the political sphere, but in attempts to imprison him, ruin him financially, and to kill him.

Clifford's criticism of local party leaders began soon after he arrived in Martinsburg to teach at the Sumner School and continued to grow during the next several years. By 1880, leaders of the controlling Republican faction in Berkeley County that included William H. Riggs, Chairman of the Executive Committee, state legislator George F. Evans, John T. Riley, editor of the Martinsburg Herald, and Perry A. Rohrbaugh, Martinsburg’s Prosecuting Attorney, were

\footnotetext{
${ }^{1}$ Pioneer Press, March 1887.

2 Bess Beatty, A Revolution Gone Backward: The Black Response to National Politics, 1876-1897 (New York: Greenwood Press, 1987), 24-25.
} 
eager to have Clifford removed from his teaching position, thus limiting his influence on the black community. Clifford reported that "this low class of white buckwheat-faced Republicans worked with a lower class of treacherous blacks" in an attempt to get him fired from his position as a schoolteacher in Martinsburg. ${ }^{3}$ Despite their efforts, Clifford remained at the Sumner School. He also remained active in politics, where he persistently demanded that party leaders adhere to the original principles of the Republican Party.

Late in 1883, almost ten years after it occurred, the Tallifero lynching became a political issue, igniting the conflict between Clifford and the Republican leaders in Berkeley County. Under Riggs, the Berkeley County Republican Executive Committee nominated George F. Evans for Postmaster of Martinsburg, a position held by attorney J. Nelson Wisner. In addition to his position in the leading Republican faction, Evans was also a Master Workman in the Knights of Labor, where he used his influence to gain political power for local party leaders in all legislative and congressional elections and place them in positions where they could reap the most rewards. New evidence revealed that Evans knew of the plan to lynch Tallifero, but made no attempt alarm officials and no effort to stop the lynching, despite the fact that he walked two miles to the site with the mob. An affidavit provided by a Mr. Amey, who was with Evans at the time, confirmed Evans role. ${ }^{4}$

Clifford protested Evan's appointment in the Pioneer Press and organized members of the black community who objected to Evan's selection, actions that brought him into direct conflict with the local Republican leadership and renewed their efforts to get rid of the outspoken editor. According to Clifford, Riggs was furious at Clifford's failure to support his Republican nominee

\footnotetext{
3 “The Nefarious John T. Reily,” Pioneer Press, July 1887.

4 "The Nefarious John T. Reily;” "The Intelligencer and the Charges Against Evans” and "Which Party Mr. Evans?” Martinsburg Independent, March 1, 1884.
} 
for the position and plotted, along with his cohorts Evans and Rohrbaugh, to send Clifford to jail. ${ }^{5}$

In January of 1884, Prosecuting Attorney Rohrbaugh brought an indictment against

Clifford for the State of West Virginia on the charge of embezzlement. The court maintained that

J.R. Clifford, while acting as the chief officer and collecting agent for the Knights of Wise Men

Lodge No. 152 in Martinsburg, “feloniously embezzled” for his own use the sum of eighteen

dollars and forty cents. Witnesses summoned for the state included six members of the Corsey

family, two members of the Duval family, and several others. Clifford pleaded not guilty and

after he and his attorney, J. Nelson Wisner, each put up a surety of \$100.00, Judge Charles J.

Faulkner, Jr., continued the case until the next term of court. ${ }^{6}$

Despite the charges issued against him, in February Clifford attended a meeting of the

Committee on Post-Offices and Post Roads of the United States Senate with Charles B. Hart, editor of the Wheeling Intelligencer, Judge Hoge, and Rev. H.E. Keyes of the Free Will Baptist

Church (African American) to discuss the appointment of George F. Evans as postmaster. In addition, 132 black voters signed a petition to the Committee charging that George F. Evans should not be confirmed as the Postmaster of Martinsburg due to his knowledge and participation in the Taliffero lynching. The petition read:

Martinsburg, W.Va.

January $31^{\text {st }}, 1884$

To the Committee on Post-Offices and Post Roads of the United States Senate.

The undersigned colored citizens and voters of Martinsburg, W.Va., recognizing the force of recent speeches in the United States Senate on behalf of law and order and its application in a proper manner to all American citizens, respectfully oppose the confirmation of Geo. F. Evans, as Postmaster of Martinsburg. If not an active participant, he certainly was present and followed with the crowd, who on the night of August $13^{\text {th }}$,

\footnotetext{
5 “The Nefarious John T. Reily,” “The Intelligencer and the Charges Against Evans,” and “Which Party Mr. Evans?”

${ }^{6}$ Law Order Book 6, 380, Berkeley County Circuit Clerk’s Office, Berkeley County Courthouse, Martinsburg, West Virginia (hereafter recorded as BCCCO).
} 
1874, took from the county jail and from the hands of the law, a colored man named John Tallifero, and, without warrant of process or color of authority, lynched him. The distance from the jail to the place of lynching is nearly two miles, and the effect of following with a mob of wrong doers, in its most violent sense, bears with it a legal culpability and a moral taint unbecoming a law-abiding citizen, in a civilized country. We have heretofore voted for Mr. Evans, but, we had no knowledge then of such inexcusable conduct on his part; but now, knowing it, we deem it our duty to disapprove it, and to respectfully request one of the highest branches of our government to reject, as unworthy of position under the law, a person connected in any way with its violation. No man should be greater than the law. ${ }^{7}$

However, the United States Senate upheld Evans appointment, leading D.S. (Sonny)

Eichelberger, Jr., editor of the Democratic Martinsburg Statesman, to brag about Clifford’s defeat and to applaud the Senate for its vindication of Evan's character. Eichelberger wrote that African Americans, meaning Clifford and Keyes, assailed Evans "by the base use of Negro petitions, obtained by a flagrant imposition upon their native ignorance.” In response, J. Nelson Wisner replied in the Martinsburg Independent that "Sonny" had nothing to brag about when compared with the "native intelligence of either Prof. Clifford or Rev. H.E. Keys.”

Claiming that a "nigger" had no business taking part in a white man’s fight, Riggs called Clifford a “d—n yellow son of a b----;” a statement that quickly got back to Clifford. Clifford took Riggs to task for the comments in both the Pioneer Press and the Martinsburg Independent, calling them an attack on his "character, color, independence, right of choice, and method of frank execution.” ${ }^{, 9}$ Riggs, however, denied the comments. ${ }^{10}$ The Martinsburg Herald, operated by John T. Reilly, defended Riggs and maintained that he was a gentleman ... a "high toned and

\footnotetext{
7“'Attach the Following to the Evans' Commission” and "The Intelligencer and the Charges Against Evans,” Martinsburg Independent, March 1, 1884. Ironically, George F. Evans may have experienced some of the fear Taliferro had when members of a circus performing in Martinsburg in September of 1892 attempted to lynch him. Evans ordered his black servant, Veney to shoot anyone who attempted to cross his grounds, leading Veney to shoot and kill a white man who associated with the circus. In this incident, the circus owner prevented the hanging of both Evans and Veney. Hagerstown Torch Light, September 1, 1892.

8 "Attach the Following to the Evans' Commission" and "The Intelligencer and the Charges Against Evans;" Hagerstown Torch Light, “A Personal Card,” Martinsburg Independent, March 8, 1884.

9 J.R. Clifford, "To the Editors of the Herald and Their Cosmo-Political Band of Republican (?) Rulers or Ruiners," Martinsburg Independent, May 10, 1884; and Martinsburg Independent, May 24, 1884.
} 
honorable man" who the party could not afford to have assailed. Reilly also insisted that "this guerrilla warfare has gone on long enough."11 The Herald also reported that the "fight between the Republican factions over this Post Office was exceedingly bitter," and that Wisner, the former Postmaster, was turned out because he did not belong to the Goff ring and was unwilling to use his office to promote the political schemes of the Republican boss of West Virginia. ${ }^{12}$

Indeed, the fight over the post office position led to bitterness between Clifford and William H.H. Flick, a Republican lawyer and author of the Flick Amendment that called for universal manhood suffrage in West Virginia. Flick, like Riggs, expected Clifford to support the controlling Republican faction, of which Flick was a member. Clifford maintained that when the post office contest took place it was his privilege as a citizen to decide whether to support Evans or Wisner. Clifford based his decision two important facts: Evans participation in the Taliferro lynching and his respect for Wisner, with whom he was studying law. ${ }^{13}$

Despite their prior friendship and Clifford's political support, Flick refused to teach Clifford law for “want of time.” Yet on the day of Clifford's request, and in Clifford's presence, Flick offered to take a white student. ${ }^{14}$ Wisner, on the other hand, not only permitted Clifford to study law with him, he allowed him to use the presses of the Martinsburg Independent to publish the Pioneer Press, served as his legal counsel, and provided his own money as surety in Clifford's court case.

In April of 1884, Clifford's case came before the Circuit Court. Although Rohrbaugh dismissed every Republican on the grand jury, knowing that most Democrats would oppose

\footnotetext{
10 “Flick vs. Clifford,” Pioneer Press, October 1886.

11 "To the Editors of the Herald and Their Cosmo-Political Band of Republican (?) Rulers or Ruiners, 1;” and Martinsburg Independent, May 24, 1884.

${ }^{12}$ Martinsburg Herald, March 6, 1884.

13 "Flick vs. Clifford."

14 "Flick vs. Clifford."
} 
Clifford, on April 9, 1884, a Martinsburg jury ruled that J.R. Clifford was "not guilty” of embezzlement. ${ }^{15}$ Immediately, the prosecutor indicted Clifford for bribery, and when it was quashed, Rohrbaugh and the alleged bribe taker rushed back into the courtroom and had another indictment issued for forgery, forcing Clifford and Wisner to provide surety of $\$ 500.00$ each. ${ }^{16}$ According to Rohrbaugh, Washington Corsey and S.R. Walker provided information showing that on June 24, 1882, Clifford forged a receipt purported to be a receipt belonging to officials of the Supreme Grand Lodge of the Knights of Wise Men of the World headquartered in Nashville, Tennessee. The grand jury dismissed the second indictment on forgery after eight minutes of debate, only to have Rohrbaugh issue another one for larceny. Once again, the jury found Clifford "not guilty."17 Clifford later stated in the Pioneer Press that he had never seen a parallel case of such "rascality, persecution, malice and hard-square lying” in the county or in the state. ${ }^{18}$ None of these charges came from the members of The Knights of Wise Men, with whom Clifford remained friends. As the organizing agent for the group in West Virginia, Clifford apparently signed receipts for the payment of dues on behalf of the Knights' Supreme Grand Treasurer, I.E. Eakin. ${ }^{19}$

Hostility towards Clifford surfaced again at the 1884 State Republican Convention held at Martinsburg during the first week of May. Although Clifford was made assistant secretary at the meeting, Berkeley County Republicans remained unhappy with Clifford's political aspirations and their political tactics at the 1884 state convention made this clear. ${ }^{20}$ At the convention, Rev. George E. Curry from Jefferson County nominated Clifford as a delegate-at-large to the Chicago

\footnotetext{
${ }^{15}$ Law Order Book 6, 414, BCCCO.

${ }^{16}$ Law Order Book 6, 415, 420, 424.

${ }^{17}$ Law Order Book 6, 415, 420, 424; “The Nefarious John T. Reily.”

18 "The Nefarious John T. Reily."

${ }^{19}$ Law Order Book 6. 420-424.

${ }^{20}$ Martinsburg Independent, May 3, 1884; and "Flick vs. Clifford.”
} 
National Republican Convention. Clifford's opponent for the nomination was William O. Dawson, a future West Virginia governor. The convention delegates elected Clifford by a majority of fifteen votes, but the Republican leaders from Berkeley County quickly overturned the vote. After Riggs declared that "no d-n nigger will go to Chicago as a delegate from this State, and don’t you forget it,” William H.H. Flick deliberately went from delegation to delegation at the convention remarking on Clifford's indictment and changing votes from Clifford to Dawson. After declaring Dawson the winner, the delegates should have named Clifford as his alternate. Nonetheless, when the convention was over, Clifford was not even given the "great honor” of being the alternate delegate, a position traditionally given to black party members. ${ }^{21}$ Although there were over a thousand witnesses, Flick denied working against Clifford. Clifford, however, insisted, “They tried their level best to paralyze me politically, but they have given me new vitality."22

At the Republican State Convention held in Parkersburg on July 30, 1884, delegates chose George F. Evans as the permanent chair. Clifford nominated J. Nelson Wisner, a former Radical Republican turned “independent,” for the United States Congress. Although Wisner was not chosen as one of the candidates in contention for the Republican nomination, delegates from Morgan, Berkeley, and Jefferson counties all voted for him except for George Evans and John T. Reily. Soon after the meeting, Clifford and Flick met in Parkersburg. Flick still denied working against Clifford and after discussing the matter, Clifford agreed to support Flick in the next election. $^{23}$

In response to Clifford's nomination of Wisner, a “special correspondent” to the Martinsburg Herald labeled Clifford with the derogatory term "Cuffy.” Outraged, Clifford asked

21 "Flick vs. Clifford.” 
Postmaster Evans:

Have you forgotten the time when a colored being went into your store, called you a liar, snatched up one of your weights to hit you with and then ran independently to beat you; and poor "Cuffy' was following the divine hither and thither in your interest, at his own expense? Do you remember anything about the 'Indian War Clubs' and 'horse pistol' held by firm grasps, with which to injure the good Lord's shepherd? ${ }^{24}$

Clifford went on to attack Evan's lack of character and education:

When 'Cuffy' scoured the country for the 'special correspondent' he was Mr. Clifford” . . . 'Cuffy' has canvassed this county during every campaign, paying his own expense and he never while at North Mountain feigned to be a Catholic to get votes, and a Protestant in Martinsburg” ...

Had 'Cuffy' been elected Chairman of the State Convention he would not have said cheer for chair, gonizing for enthusiasm, and 'the amendments is disposed of,' for are disposed of. Suffice it to say, if 'Cuffy' don't wear a beaver-hat, he owns a little grammatical accuracy under a common one, and has enough common sense-that rare thing — not to occupy a position where a parliamentary technicality would lock his mouth, knock him down in the cheer, and sit there dumb. ${ }^{25}$

In what Clifford called a "short but 'pinted"” sermon in "Negro-ology" titled "Better to be in the House of Mourning than that of Feasting and Office Making," Clifford presented a harsh image of Evans:

Conscience to 'Cuffy': “Suppose your child was sick, would you go to a convention?” "No, sah."

"What would you do if your child was dead-go to a State convention, full of hostility, and contend for committee honors?”

"No, indeed, sah?"

“Cuffy, what would you have done?”

"Stayed home with de poor agonizing' wife and tried to 'sole her."

"Cuffy, would you wear a shirt collar in a Congressional convention?”

“Most sartin, sah! Brethrin dare will be preachin' in a fu mor' days, if de Lord willin' and it don't rain, and in a fu mor days dar will be preachin' anyhow.” "Master, wood you gone to de convention under de 'bove cerkumstances?” "No, my Cuffy."26

\footnotetext{
22 "To the Editors of the Herald and Their Cosmo-Political Band of Republican (?) Rulers or Ruiners.

23 "Flick vs. Clifford." For Clifford's nomination speech on behalf of Wisner see Appendix II.

${ }^{24}$ J.R. Clifford, “The 'Herald' Calls a Colored Man 'Cuffy,'” Martinsburg Independent, August 16, 1884. The divine referred to was H.E. Keyes who accused Keyes of plotting with E.B. Faulkner to defeat the Republican Party. 25 "The 'Herald' Calls a Colored Man 'Cuffy.”,

26 “The 'Herald' Calls a Colored Man 'Cuffy.””
} 
In August, Wisner gleefully reported in the Martinsburg Independent that "Cuffy" would be speaking at the Soldiers and Sailors Re-Union to be held on August $26^{\text {th }}$ in Chicago, Illinois. Announcing that Professor J.R. Clifford would take the stand with Generals John A. Logan, Richard J. Oglesby, and J.C. Black, Wisner said of the honor, "Rather think some of his traducers here will not be able to keep up with him, much less get ahead, in the race of life..27

Wisner maintained that the Republican Party in Berkeley County was a "party handicapped by Riggs, Rohrbaugh, Riley and Evans” and, therefore, hard to support. He referred to it as a closed corporation made up of Riggs, who came to Berkeley County as an office-holder and had never drawn a breath out of office for over fourteen years while drawing pay from a position with no labor; Riley, who published the Herald in a disgraceful manner and claimed he could not publish a Republican paper in Martinsburg with J.N. Wisner as postmaster; and Evans, who was compelled to admit that he waited for an hour, near midnight, within a few feet of the jail, for a mob to come and lynch a condemned colored man. Wisner insisted, "The independent ballot will right many local wrongs, and point a moral that will leave a deep impress.”28

Soon after the Parkersburg convention, Clifford began receiving letters from across the eastern panhandle; letters that accused him of taking money to oppose Flick and threatened him for his stance. Clifford denied being bribed, and in the Press stated that he "could have, and still could, get money to pay for a printing press and every appurtenance along with money,” but that he had "too much race interest and too much manliness to be bought, and too much vim to be scared.,29

Although Flick refuted any implication that he was working against Clifford, when Senator B.K. Bruce and Fredrick Douglass appointed Clifford as an Honorary Commissioner to

27 “’'Cuffy’ Honored,”Martinsburg Independent, August 23, 1884. 
the World's Industrial and Cotton Centennial Exposition to be held in New Orleans from

December 16, 1884 to May 31, 1885, it was Flick who went to Washington, D.C. at the urging of Riggs, Evans, and Rohrbaugh and attempted to have the commission taken from Clifford. When Clifford went to meet with those distinguished men later in 1884, Flick labeled him a “whipperwhopper” and said "let the d—nigger go to $\mathrm{h} — \mathrm{l}$. ”30 Clifford finally admitted that up until that time, he had been "used” by these very "dough-faced, bread and butter politicians.”31

Despite Clifford's failure to capture a delegate's spot from West Virginia to the National Republican Convention in Chicago, he attended the convention in September along with several other prominent African Americans, including Mississippi delegates B.K. Bruce and John R. Lynch. Clifford later reported, “we saw Theodore Roosevelt contend for three hours to make John R. Lynch temporary chairman of the National Republican convention at Chicago, and he won.”32 The young New Yorker made a lasting impression on Clifford.

A “Lincoln Republican,” Clifford continued to insist that the Republican Party in Berkeley County, and throughout West Virginia, adhere to the original principles of the party. After studying law with Wisner, he prepared to take his bar exam in the summer of 1885 . Judge Faulkner and Judge Armstrong administered the exam. However, Clifford failed his first bar examination to the delight of many in the Republican Party. John T. Reily, editor of the Martinsburg Herald, was particularly malicious when reporting the news. In response to Reily's editorials, Clifford wrote that it, "shows how envious and malicious this notorious Negro loving Republican is toward a colored man who rises above the stand where he can't be 'put to political

\footnotetext{
28 “Republican Jeopardy,” Martinsburg Independent, September 27, 1884.

29 "Flick vs. Clifford."

30 "Flick vs. Clifford."

31 “The Nefarious John T. Reily."

32 “T.R.,” Pioneer Press, June 6, 1914.
} 
use. ”,33 Since the local party officials could not control Clifford, they labeled him a "Democrat,” knowing it would inflame Republican devotees in the black community. Clifford argued in the Press that he was not a Democrat, but "whenever a colored man has, and expresses an advanced thought as to reasonable religion, he is by a certain class of blacks called an "infidel," and whenever he votes to suit himself, he is, by another class of whites, a "Democrat."34 Clifford believed that all men should be able to think and act for themselves. He wrote in the Pioneer Press, "we shall boldly advocate our thoughts, and never swerve an inch in the full defense of the rights of our race," and then offered the use of its columns to those with differing views. He was adamant in the belief that "our people must learn to allow a man to say what he thinks without wanting to kill him for it." ${ }^{35}$

Indeed, Clifford was open and frank with the members of both parties, Republican and

Democrat. For Republicans, the issue was principles and Clifford made his stance clear:

We want it distinctly understood, that we are tired of being told before each recurring election that the Negro is a republican because he owes that much to the part. We want all parties to understand that principles with us are sacred things, and not object of merchandize, that we are actuated by the same motives in our republicanism that actuate white men, that whatever debts we owe, when the bills are presented will be settled as other men settle theirs, but not at the sacrifice of principles. Are we understood? ${ }^{36}$

As for Democrats, if they wanted the black vote, they needed to earn it. Clifford expected Democrats to make amends for past deeds and that they would work with African Americans instead of against them. He wrote:

The Democratic party says to us, 'we are your friends.' Very well, we need friendship; And we are closely watching and sifting the kind you offer us. Some colored people who Were treated humanly, under the inhuman system, to this day, remain on the 'old Plantation;' hence, to encourage us to think well of you, you as a party, must regret the Past, disregard color, and make every possible amend. See that the Blair Educational Bill

\footnotetext{
33 “The Nefarious John T. Reily.”

${ }^{34}$ Pioneer Press, August 1885.

${ }^{35}$ Pioneer Press, August 1885.

36 “A Reply,” Pioneer Press, August 1885.
} 
Passes the House, as it did the Senate, and we will score an everlasting mark of friendship In your favor. ${ }^{37}$

Indeed more black West Virginians were beginning to express their points of view, and several wrote about them in the pages of the Pioneer Press. Clifford established co-editors in Parkersburg, Wheeling, and Weston, West Virginia, and Mt. Pleasant, Ohio, who wrote articles for the paper. All were educated, articulate men: J.L. Champ, principal, and Professor A.W. Peques of Parkersburg; Rev. G.W. Hollinger and Professor J. McHenry Jones from Wheeling; George T. Jones, principal of the school at Weston; and Rev. E.E. Underwood of Mt. Pleasant, Ohio. All of Clifford's co-editors were African American, and all of them were Republican. A few other men, including Robert W. Simmons and George W. Hatter, occasionally wrote articles in the Press as well. Despite the bitterness among Republicans in the eastern panhandle, Clifford still professed his allegiance to the party at the state and national level, as long as it adhered to principles of Lincoln. In August of 1885 he wrote:

We want it thoroughly understood that we own a pew in the Republican church, and that we intend to stay therein, brush down the cobwebs, scrub and fresco it, and pay our annual fee of loyalty. We oppose a gallery, exclusively for colored members, and are in favor of all communing at the same table, and at the same time; with as little thought as to who is white or black as a white man's ballot thinks of a black man's ballot when cast into the same box. We believe that it is cowardly to get mad, leave and build another church when things don't suit you, but that is manly to stay inside and battle for purity and full right of every member. Every member who will become offended at such work for the perpetuity of the sanctuary, is a backslider, and should be expelled or reconverted, and vigilantly watched, on probation of six months. ${ }^{38}$

For African Americans living in the eastern panhandle, the year 1886 started out on a chilling note. In February, whites in Martinsburg lynched another African American, Joe Burns, for an assault on sixteen-year-old Mary (Mollie) Fellers. Up the Winchester Pike next to Big Springs a mob of 300 "made the night hideous with Indian whoops, loud cursing and demoniac

\footnotetext{
${ }^{37}$ Pioneer Press, August 1885.
} 
yells;” and then it was silent ${ }^{39}$ The Spirit of Jefferson reported:

No one who saw the scene will ever forget it. A little woods nestling on the Winchester Pike, and the moonbeams stealing between the old trees, upon the road. A silent crowd of masked men, the neighing of horses, and the straight black figure standing out in bold relief against the hills. The awful questions; the sullen, calm answers; the wild shouts of rage; the blazing revolvers; the choking, swinging body, and then the quiet wood again and the motionless, bleeding body above the white pike. This is a true picture of the wrath of man. ${ }^{40}$

If the Burns lynching made Clifford uneasy, he did not show it. However, after six years of fighting those who were trying to oust him from his position, Clifford resigned from the Sumner School in Martinsburg in May of 1886 to spend more time on the Pioneer Press and to study for the bar exam. The Berkeley County Board of Education recognized "his past service, faithfulness, care and energy" for the previous ten years, stating that they had "always found him at his post of duty, laboring for the intellectual and moral advancement of his pupils.” The board claimed that the school losing an efficient head and the citizens were losing an "upright, painstaking teacher." ${ }^{41}$ Years later when a former student at Sumner School thanked Clifford "for combing my head and washing my face,” Clifford reported:

I am confident I combed 200 or more heads and washed as many faces and hands to make them clean and instill the duty within themselves, during the ten years and three months I taught here. I half-soled scores of tot's shoes and clothed as many scores, and wherever they are found, if they had a spark of pride in them in the out-start, they are respectable citizens and doing well. In addition to our work as principal of this school we made a relentless warfare against the low grade of teachers (?) in Berkeley county and never let up till every one was put out and up-to-date ones put in. ${ }^{42}$

That spring, Clifford learned to ride a bicycle for the first time. He bought a nickel bicycle called the "Ideal Bicycle” from Gormully \& Jeffery of Chicago, Illinois, that provided

\footnotetext{
${ }^{38}$ Pioneer Press, August 1885.

39 “A Young Girl Assaulted,” Spirit of Jefferson, February 23, 1886.

40 "A Young Girl Assaulted."

41 "The Nefarious John T. Reily."

${ }^{42}$ Pioneer Press, December 16, 1916.
} 
him with an efficient mode of transportation as well as hours of fun and relaxation. Considered "racy" as well as dangerous, the 158 pound Clifford rode all over Martinsburg and the "roughest country roads admissible.” The bicycle served him well and was often a source of freedom for Clifford. After he rode with the "wheelmen," a group of white gentlemen, in nearby Hagerstown, Maryland, Clifford expressed the exhilaration and freedom he experienced when he wrote, "We enjoyed ourself so much, we forgot that we were in complexion akin to the Afro American, until we accidentally passed Mr. Updegraff's store with windows so clean we beheld our likeness.”33

Despite Clifford's continued challenges and criticisms in the Pioneer Press, the Republican Party leaders in the eastern panhandle continued to ignore the party’s black members, except when it wanted their vote. A good example of this occurred in 1886 when the Jefferson County Republicans held a meeting at Storer College to elect twenty delegates to the state convention at Keyser. Jefferson County was traditionally a stronghold for the Democratic Party, so the number of Republican voters in the county was relatively small. Among the Republicans, there were 1,100 black voters and only 175 white voters. Yet at the meeting, party leaders nominated and elected all twenty delegates from the white membership. Tied to national party leaders, this small group of white Republicans from Jefferson County held thirteen federal patronage jobs. Their failure to elect African American delegates to the convention was not due to a lack of candidates. Prominent black citizens from Jefferson County, such as William H. Bell, W.B. Hill, J.E. Berrell, and George W. Hatter, attended the meeting, a few of whom upbraided the white Republicans for their failure to elect black representatives. The whites reconsidered,

\footnotetext{
43 “A Big Bicycle Record” and “Among the Wheelmen on the 13 Inst.,” Pioneer Press, June 1887; “The Bicycle,” May 1887. The "wheelmen" referred to were most likely members of the League of American Wheelmen, a national bicycle organization organized in 1880. There is no indication that Clifford was a member of the organization, and in 1894, the League of American Wheelmen banned African Americans from the organization at their national convention due to the efforts of southern members and the rise of Jim Crow throughout the south. However, it was the rising prominence of an African American known as the "Worchester Whirlwind," Marshall W. Taylor, that
} 
placing five blacks in the delegation, all of whom refused to attend the convention. ${ }^{44}$

Reacting to the political maneuvers going on in his neighboring county, J.R. Clifford

wrote:

The time was, when we thought it impossible to be independent in politics, but 'wise men change, fools never.' Now, we not only consider it wise in the extreme, but also consider its increasing strength, indicative of honesty, good sense, and will be the salvation of the government. Hereafter, so long as we live in the State of West Virginia, so long will we be the slave of no political party." To blacks: "So long as you scrape and bow at the shrine of one party, and swear by Him that ruleth that you will remain therein, in spite of insults and moonlight promises, so long will you be treated as you have been." "We do not ask the colored men of this State to be democrats-but we do ask them to be independent men-a thing impossible by cursing all other parties and sticking to a party that curses you. ${ }^{45}$

George W. Hatter, who attended the meeting, also wrote an article for the Pioneer Press stating:

Whenever the colored man reaches that stage of intelligence and independence that he is unwilling to bow the knee at the Republican shrine as a serf or a slave of the party he is branded an enemy to his race. All men except those who wear black skin are allowed and expected to act with freedom and independence, but if his skin is dark he is expected to submit to the dictates and domineering of his political lords and masters. And as long as we will submit to this lording it over us by the republican party or any other party we may expect to wear the yoke of bondage and be regarded as mere political dupes. Let us lay aside the prejudices which inflame our passions and bias our judgments and forgetting that we are black men appear on the political arena as free and independent American Citizens! ${ }^{46}$

Both Clifford and Hatter made it clear that views they expressed referred to the "black sheep and wolves” of the party, the political bosses who claimed to represent Republican principles.

Clifford wrote that there were "genuine Republicans in this state," who, "if at head of affairs, past fealty to the party would be the same.” Both men felt the current Republican leadership did not adhere to the Republican principles of Lincoln and Sumner, and therefore, they had no obligation

\footnotetext{
initiated the action among the cyclists.

44 “Buckwheat Faced Republicans," Pioneer Press, September 1886.

45 "Independent in Politics,” Pioneer Press, September 1886. For the complete editorial see Appendix III.

${ }^{46}$ George W. Hatter, “Shall We Be Men,” Pioneer Press, November 1886.
} 
to support them. ${ }^{47}$ One white Republican, C. Tabler, stated that he "would go to no convention of damn Niggers." Clifford responded that "there were colored men in that convention as far ahead of him [Tabler] in brilliancy of intelligence, manhood and self-respect as the sun is in comparison with the moon" and that it was "this class of republican sapsuckers that the Pioneer Press is showing up and putting down." ${ }^{48}$ In an article written for the Pioneer Press, J.L. Champ made the position of many of these men clear:

We want it distinctly understood, that we are tired of being told before each recurring election that the Negro is a republican because he owes that much to the party. We want all parties to understand that principles with us are sacred things, and not objects of merchandize, that we are actuated by the same motives in republicanism that actuate white men, that whatever debts we owe, when the bills are presented will be settled as other men settle theirs, but not at the sacrifice of principles. Are we understood? ${ }^{49}$

Clifford was among the first to acknowledge that his outspoken behavior made life difficult. Still, he could not, and would not, refrain from commenting on moral lassitude or social and political injustice in the Press. He explained, "The wife, whom I love above all living beings, and who has done more to make me a man of letters than any living being, has cried many a day and night, because I've published things in the Pioneer Press, relating to local issues, which I know to be wrong and which have been throttled, and are acknowledged by her and many others as wise. So, you see, if she can't change me, no one else can; unless it be done by force of reason, to which, when right, I always yield." ${ }^{50}$ If Clifford yielded, it was not often. In the fall election of 1886, Clifford once again supported J. Nelson Wisner in his bid for Congress over his opponent William H.H. Flick. Clifford maintained Flick was supported by hundreds of Democrats and opposed by hundreds of Republicans, implying Flick's actions belied

\footnotetext{
47 "Flick vs. Clifford."

${ }^{48}$ Pioneer Press, October 1886.

49 J.L. Champ, “Can Colored Men Consistently Support the Democratic Party?” Pioneer Press, August 1888.

50 "Flick vs. Clifford."
} 
his rhetoric. Yet it was Clifford, because of his fidelity to Wisner, who faced the most vocal and public criticism. In an editorial, Professor Brackett, president of Storer Normal School, stated, "There is no use in denying the fact, colored men have no faith in a colored Democrat. To every man, and doubly so to the women, he is a traitor to his own race.”51

In the face of overwhelming criticism, Clifford refused to be silent. Encouraging voters to vote for men and not parties, Clifford insisted:

The intelligent voters in this county are more numerous now than ever before. Men, as well as principles; actions, as well as pretensions; ability, as well as honesty, will be considered this fall. The day for voting blindly and indiscriminately, has passed. Intelligence and independence have lifted the burden from voter's back and silenced to a great extent the crack of the party whip. Vote your sentiments; let no organization dictate your course; fire for the best target. ${ }^{52}$

According to an article in the Pioneer Press, Clifford's position was a dangerous one.

Members of his own party, angry over Clifford's criticism of the Republican Party and his support for Wisner, threatened his life. A week before the November election Clifford and Hatter traveled to the Charles Town courthouse after hearing a rumor that Flick would be speaking there. Clifford wanted to confront Flick over the statements he made concerning Clifford and the Pioneer Press. Flick was not there. However, there was a small group of men gathered in the Baptist church. Addressing the group was a man named B.F. Liesenring who, Clifford claimed, was making libelous statements about him and using inappropriate language inside the church. After Liesenring finished speaking, a few of the men invited Clifford to address the crowd. Mounting a box, Clifford began to speak only to be interrupted by a man Clifford referred to as an “illiterate black" who began heckling Clifford at Liesenring's urging. However, a few of the men in the group insisted that Clifford be heard, and going to the courthouse, rang the bell. Within

\footnotetext{
51 “Independence and Not Democracy,” Pioneer Press, November 1886.

${ }^{52}$ Pioneer Press, September 1886.
} 
minutes, men of both races packed the church. Clifford spoke to the group for thirty-five minutes and, afterward, George W. Hatter made a few comments. ${ }^{53}$

Following the meeting, Clifford and Hatter planned to travel to Hatter's home in Harper's Ferry. Clifford's white driver was afraid to drive the buggy, saying that a group of twenty men were waiting on the road to kill Clifford. Finally, he agreed and just as the buggy pulled out, a young African American named John J. Dixon jumped onto the buggy, promising Clifford that he would get through. When they met the crowd about a mile out of town, Clifford held a pistol in each hand while Dixon took the reins, yelled sharply at the horse, and drove the buggy right through the mob. ${ }^{54}$

After the meeting, B.F. Liesenring reported to his fellow citizens that Clifford agreed to support Flick, but then abandoned his Flick’s campaign for Wisner. Dr. Border from Kearneysville also told blacks in Jefferson County that Clifford had been bought and that he was a traitor. ${ }^{55}$ However, Rev. S.A. Lewis, who was present during a conversation between Liesenring and Clifford, reported that "Mr. J.R. Clifford, on bitter personal grounds, opposed Mr. Flick" and that Clifford told Liesenring that his interest was in the race and that if ten thousand dollars were offered him to support Mr. Flick, he would turn it down and consider it an insult. ${ }^{56}$ Many blacks failed to believe Clifford and, once again, black ministers condemned Clifford from the pulpit. ${ }^{57}$

Upon losing the election, Flick openly acknowledged the potency of Clifford’s “dirty little sheet.” When Clifford learned that people were calling him the father of Flick's defeat, he

\footnotetext{
53 "Independent and Not Democracy."

54 "Independent and Not Democracy."

${ }^{55}$ Pioneer Press, August 1888.

${ }^{56}$ Pioneer Press, August 1888.

${ }^{57}$ Pioneer Press, November 1886.
} 
proudly responded with "then call me daddy." ${ }^{58}$ Growing weary of Flick’s constant complaining about both him and his paper, Clifford referred to their childhood "friendship" in a letter posted in the Pioneer Press: “Says Bob to Bill. When you knocked me down I stood it like a turk. I didn’t tell pap, nor did I whine either! Now when I've knocked you down, can’t you do the same?” Instead, Republican leaders urged blacks to boycott the Press, calling Clifford a Democrat and, therefore, a traitor to his race. Clifford denied both, but insisted that blacks would never succeed until black voters divided their vote between the two major parties. ${ }^{59}$ However, Clifford reported that because he had "the manhood to assert black rights and resent personal wrongs to himself and his people," thirty-two subscribers dropped their subscriptions to the Pioneer Press. Determined to defend his principles, Clifford declared that if he lost all 700 subscribers, the Pioneer Press "never had, and never would back down an inch in the defense of the rights of the race and that if there wasn’t enough manly men of color to support it, then let it die.” ${ }^{\text {,60 }}$ Faced with growing opposition, Clifford wrote that "it seems to be the determination of the white republicans (?) to choke the life out of the Pioneer Press, because it vindicated the rights of free men, in a free country."

The economic woes of the Press continued into the following year with one reader, Mrs. Angeline Francis of Piedmont, bluntly writing, "I do not wish your Democrat paper any longer." Although Clifford replied that there was "quite a difference between a Democratic and an Independent newspaper," his readership continued to decline. ${ }^{62}$ Yet threatened with prison, mob violence, and even death, Clifford continued to use the Pioneer Press to chastise the Republican

\footnotetext{
${ }^{58}$ Pioneer Press, November 1886.

${ }^{59}$ Pioneer Press, November 1886.

60 “The Thirty-Two,” Pioneer Press, October 1886.

${ }^{61}$ Pioneer Press, November 1886. The question mark in the quotation is Clifford's. Apparently he was questioning whether or not they were truly "Republicans."

${ }^{62}$ Pioneer Press, May 1887.
} 
Party for its failure to address the economic, social, and political interests of African Americans.

Tension increased in the spring and summer of 1887 after Clifford passed his bar examination, becoming the first African American to study and practice law in the state of West Virginia. While in Wheeling to attend the state Odd Fellows meeting and to confer with three of his assistant editors, Clifford went before the Supreme Court and was admitted to the bar. Skeptical of being accepted to the bar after his last attempt, he wrote, "I was more dubious of my successful examination than was Thomas of the Savior's resurrection.” When John T. Reily of the Martinsburg Herald heard the news, he accused Clifford of buying or bribing the examining judges. Inferring that Clifford was a prime candidate for lynching, Reily stated that "if negro outrages in the South are confined to such political characters, it is good work and one that should go on for the welfare of both races." Clifford understood his meaning, stating in the Press that “He virtually meant, that whenever a colored person can’t be 'put to political use,' the best thing to do is to take him out and hang him, or go to his house and riddle him with buckshot---and this being urged in the town of Martinsburg---the wretch! But pardon me, he is a Republican!”,63 Clifford explained that a white man's real opinion of blacks was only clear at election time. Before elections, whites called African Americans "Mr." and spoke politely, but afterward, blacks were treated coolly and referred to by their first names. Another class, he insisted, was "always harping about their friendship and what they have done for you that you might be free," but if you dared to vote against their wishes, they were as "mad as hornets." ${ }^{\text {64 }}$ In truth, local party leaders did not want to see an intelligent black man, who made his own decisions, rising above what they perceived as "his place.” In addition to passing the bar exam, Hon. B.S. Morgan, the State Superintendent of Free Schools appointed Clifford to conduct the Teachers’ Institute

63 “The Nefarious John T. Reily;” “For Colored Voters,” Wheeling Register, 14 September 14, 1888. 
(Peabody Institute) at Storer College held in June. Teachers at the Institute included Coralie Franklin, Page, Hatter, and the Arter brothers, Jared and William. ${ }^{65}$

In an effort to belittle Clifford's achievements, Reily reported in the Herald that Clifford was not the first African American lawyer in the state and claimed the honor belonged to John $\mathrm{H}$. Hill. Clifford said he would not argue with Reily, but he did want to explain why he believed he was the "first colored lawyer in the state." Hill, Clifford pointed out, did not read law in West Virginia and, although he was a lawyer, did not practice in the state. Clifford also added that Hill was "as white as any ordinary white man" and heard that he was somewhere "now passing as a white man.” Therefore, Clifford maintained that "under the circumstances, if there is any honor in being the first colored man licensed to practice in this State, we think, in a modest way, that we are entitled to it. John T. Reily, to the contrary, not withstanding." 66 Clifford was only half right. Born in West Virginia, Hill did study law in Maine where he passed the bar in 1879. Hill returned to West Virginia where he gained admittance to the Jefferson County bar in 1881, but joined the Tenth U.S. Calvary in 1882 and remained there until discharged in $1888 .{ }^{67}$

That fall, Clifford attacked the Republican Party again for failing to include African Americans. For several years, the Republicans of Berkeley County had placed no county ticket in the elections. Clifford proposed that since there was no ticket, and no chance of election even if there was one, why not nominate a few African Americans in the fall election? Clifford pointed out that black Republicans outnumbered white Republicans in the county 1,200 to 200, and that

\footnotetext{
${ }^{64}$ Pioneer Press, July 1887.

65 "Storer College Annual Institute,” Pioneer Press, June 1887.

${ }^{66}$ Pioneer Press, July 1887.

${ }^{67}$ Dorothy Withrow and Elizabeth Scobell, From the Grove to the Stars: West Virginia State College, 1891-1991 (Charleston, W.V.: Pictorial Histories Publishing Co., 1991), 8-10. Hill returned to Harpers Ferry in 1889 and became the principle of the black grade school in Shepherdstown. In 1893, he became a professor of English at West Virginia Collegiate Institute (now West Virginia State) and became principle in 1894. Hill enlisted in the Eighth U.S. Vol. Infantry during the Spanish-American War. After his discharge, Hill moved back and forth between
} 
many of the blacks were fully capable of dignifying legislative halls. ${ }^{68}$ Clifford's plea went unanswered. Despite the exclusion of African Americans from political office in Berkeley County, Clifford was able to go before West Virginia Supreme Court examiners Okey Johnson, T.C. Green and O.C. Snyder in Jefferson County on September 13, 1887 for admission to practice before the bar of the West Virginia Supreme Court of Appeals. Clifford passed the examination, an act officially sealed and documented by O.S. Long, Clerk of the Supreme Court of Appeals on Oct. 3, $1887 .^{69}$ Later that year, the Supreme Court of Appeals in the District of Columbia admitted Clifford to the bar on the motion of John W. Cromwell. ${ }^{70}$

In January of 1888, Clifford came face to face with W.H.H. Flick in a court of law when he represented J.J. Joiner in a lawsuit against Western Union Telegraph. Clifford won the case, much to Flick’s chagrin. ${ }^{71}$ Clifford also made it clear that he would not give up the Pioneer Press, regardless of whether or not it made money. Clifford described the Press as:

Not a mere moneymaker; but a labor of love. So far, it has made its way against bitter opposition, which, when open, we admire, but when covert, we anathematize it. It is independent in politics and cares nothing for parties that care nothing for the race. By this it reserves the right to do what it believes to be right, and will do the most good for the race its ambition is to benefit. It believes that an independent union of colored men will be the downfall of any political party that refuses them justice and protection; and to accomplish this, we shall labor as long as we control it. Its columns are open to the public for any discussion of interest, so it is conducted on the basis of decency. It will encourage the good acts and condemn the bad ones in a spirit of kindness and defend the race, if necessary, to its own destruction. ${ }^{72}$

In a letter dated February 22, 1888, a reader offered encouragement to Clifford stating, “We are

western states and West Virginia. Hill authored a book titled Princess Malah. Records indicate that Hill never practiced law in West Virginia.

68 “Jefferson Republicans Nominate,” Pioneer Press, September 1887.

${ }^{69}$ Paul Clifford manuscript, 18-19; Judge Okey Johnson, a Democrat from Wood County, sat on the State Supreme Court of Appeals from 1877 to 1888; Judge Samuel Woods, also a Democrat, was from Barbour County and served on the State Supreme Court from 1883 to 1888; and Judge T.C. Green, a Democrat from Jefferson County, sat on the Court from 1878 until his death in 1889.

${ }^{70}$ Pioneer Press, December 1887.

${ }^{71}$ Pioneer Press, January 31, 1888.

72 “A Moment If You Please,” Pioneer Press, January 31, 1888. 
proud of your manly course in fighting for the rights we are justly entitled to. Let me assure you Sir, that we love the Pioneer Press, the opposition of Presiding Elder Steel and a few more blind followers to the contrary not withstanding.” Like Clifford, the reader supported Nathan Goff and opposed Flick, stating that he never heard Goff say "nigger."73 That same month, John T. Reily surprised Clifford when he passed him on the street and Reily greeted him with a cordial "Good Evening." Even more surprising, Reily touted Clifford in the Herald as "the greatest educator and race elevator in the world.” In ill health, Reily was eager to make amends, and Clifford was ready and willing. ${ }^{74}$ With the Press surviving economically, Clifford purchased the printing outfit of the Hardy Express in Moorefield and planned on issuing a semi-weekly, then weekly paper. Clifford received congratulations from both the Central Methodist, and the Democratic Martinsburg Statesman. ${ }^{75}$

In the summer of 1888, Berkeley County Republicans hoped to neutralize the role of Clifford and the Pioneer Press in the coming election. Clifford wrote that "some of the Devil's republicans, we learn from good authority, have declared their intention to secretly murder us, if we oppose any of the nominees in this county this fall.” Hearing that one member of the Berkeley “ring” suggested poisoning, Clifford stated that "these fellows have opposed us on every occasion to satisfy their prejudices, and to please a set of low treacherous Negroes; and now they are very polite indeed, which is an insult. We love and will cheerfully support God's republicans, but the Devil assist the Devil’s., ${ }^{\text {76 }}$

J.R. Clifford and his editors were not the only African Americans in West Virginia disillusioned with the Republican Party and its failure to recognize the importance of black voters

\footnotetext{
73 “Ed. Pioneer Press,” Pioneer Press, February 22, 1888.

74 “Great Scott! and Holy Moses!!” Pioneer Press, February 29, 1888.

${ }^{75}$ Pioneer Press, April 30, 1888.

76 “Winchester Rifles in Arkansas, Poison and Secret International Murder in Berkeley County,” Pioneer Press,
} 
in the state. Black West Virginians held a State Independent Colored Conference at Charleston in September of 1888 with forty-nine delegates from across the state. The closed-door session resulted in the establishment of a party ticket, composed entirely of African Americans. The delegates condemned the Republican Party, claiming that the party "refused to give the colored man the recognition to which he is entitled, not withstanding the fact that there are eleven thousand colored voters in the state, nearly all of whom are Republicans.” The delegates were adamant in their opposition to monopolies, corporations, and trusts and their desire for a reduction in the tariff. Surprisingly, this group of dissatisfied voters had no connection to J.R. Clifford and his elite group of editors. Commenting on the Independent Party in the Pioneer Press, Clifford wrote:

We neither condemn nor commend the Independent move of our people in this state; for we know nothing about their affairs, or what actuated them to do as they have. If the plans are the origination of themselves for the honest purpose of obtaining recognition as all other men have, they ought to be encouraged and every colored man in this state should support them. ${ }^{77}$

The men at this convention came from all over West Virginia. Permanent chair was H.C. Hawkins from Kanawha County and the Secretary was Edward A. Turner from Brooke County. The Executive State Committee consisted of Hawkins and Turner as well as John Rose, Mason County; Albert Alexander, Hampshire County; W.A. Hunter, Barbour County; Peyton Murray, Kanawha County; Aaron Jordon, Pocahontas County; Alex Davis, Upshur County; and W.S. Peen, no county listed. Elected to the ticket as Presidential Electors were Turner and Alexander, T.M. Thurston, Hampshire County; John A. Jefferson, Kanawha County; and John Jorden, Mason County. In addition, the ticket included William H. Davis, Kanawha County, for governor;

August 1888.

77 "For Colored Voters," Wheeling Register, September 14, 1888; “The W.Va. Afro-American State Nomination,” Pioneer Press, September 28, 1888. 
Edward Turner for Auditor; and Alfred Whiting, Hampshire County, for Treasurer. ${ }^{78}$

How these men came to represent their individual counties is unclear. They ranged in ages from twenty-eight to seventy-one and the majority were either farmers or laborers, many of whom could not read or write. However, the men they chose to represent them on the ticket for governor and auditor were, like Clifford, schoolteachers. William H. Davis was forty-one years old and lived in Charleston with his wife Allie. Born in Ohio, Davis was tall, thin, and light complexioned. After serving in the “Union Light Guard,” a group often called “Lincoln’s Body Guard,” Davis came to Malden, West Virginia after the Civil War. One of his first pupils was Booker T. Washington who described Davis as a "young coloured man from Ohio, who had been a soldier."79 Edward Turner, a former barber in his twenties, taught school in Wellsburg. The reasons these men put forth in forming the independent party echoed Clifford's criticisms, and Republicans, black and white, responded to these men the same way they responded to Clifford, with anger and violence. ${ }^{80}$

News of the independent party appeared in the Wheeling Register on September 14, 1888. When classes opened at Turner's school in Wellsburg on September $17^{\text {th }}$, only four pupils were attendance. White Republicans, through persuasion or intimidation, convinced the majority of African Americans not to send their children to school. On September $18^{\text {th }}$, the school was “stampeded” and broken up by "loyal Republicans” whose feelings were expressed the following day in the newspaper:

We want it understood that we tolerate no Independent or Democratic colored man in this Pan-Handle, especially school teachers, when one bobs up as this one has.

\footnotetext{
78 “For Colored Voters;” and “The W.Va. Afro-American State Nomination.”

79 John Rueben Sheeler, "The Negro in West Virginia Before 1900 (Ph.D. dissertation, West Virginia University, 1954), 225-226; and Booker T. Washington, Up From Slavery (New York: Prestige Books, 1968. Original 1901), 346.

${ }^{80}$ Census of Population, Twelfth Census of the United States 1900, Kanawha County and Brooke County, West Virginia.
} 
Of course we will break up his school, and we ask what are you going to do about it. Remember self-preservation is the first law of nature. If a colored man is for us, all right; if he is not, we don't or won't tolerate him, that is all. A colored man must be a Republican or nothing in this Pan-Handle, or his school will be stampeded. Do you hear? ${ }^{81}$

In the election of 1888, both the Democratic and the Republican parties feared that "independent" black voters and hired laborers would sell their vote. The impact of the independent voters on the outcome of the 1888 election is questionable. However, party leaders began to recognize the growing political power of African Americans in the state; power, however, not attributable to the independent voters, but to the rapidly growing number of African American laborers migrating into West Virginia to work in the railroad and coal industries. ${ }^{82}$

Throughout the 1880s, the growing industrialization in West Virginia led to a focus on economic interests in both the Republican and Democratic parties. The integration of economic interests and political organization in the state enabled leading industrialists to protect their business interests. While both parties had factions supported by industrialists, one of the most prominent industrialists of this era, and one who eventually would have a profound impact on West Virginia, was a lawyer named Steven B. Elkins. Many West Virginia Republicans welcomed Elkins's money and organizational skills to the party cause. Others, such as state Republican leaders Nathan B. Goff and George W. Atkinson, eventually became Elkins’s rivals. In 1888, Democrats in the state accused Elkins of illegal voting tactics. That September, the Point Pleasant Weekly Register stated that Elkins had “a diabolical scheme on foot to colonize this State with voters to carry the State for the Republicans,” a statement that reflected growing

\footnotetext{
81 "Republican Intoleration,” Wheeling Daily Intelligencer, September 19, 1888; “A Fine Example,” Wheeling Daily Register, September 19, 1888.

${ }^{82}$ Sheeler, “The Negro in West Virginia,” 210; John Alexander Williams, West Virginia and the Captains of Industry (Morgantown, W.V.: West Virginia University Foundation, 1976), 118-120; and Ronald L. Lewis, Transforming the Appalachian Countryside: Railroads, Deforestation, and Social Change in Appalachia 1880-1920 (Chapel Hill: The University of North Carolina Press, 1998), 211.
} 
concern over the number of black industrial workers entering the state and their support for the Republican Party. ${ }^{83}$

James McHenry Jones of Wheeling, who formerly wrote articles for the Pioneer Press, played a significant role in the 1888 election as did Christopher H. Payne from Fayette County. Professor Jones, turning his back on Clifford and others who called for “independent” voting, traveled throughout the state speaking for the Republican cause. After hearing Jones speak in Fairmont, Clifford wrote in the Pioneer Press that "as a teacher, he ranks high, but as a politician he is at the bottom.” Most of Clifford's criticism stemmed from Jones’s statement, “I am a Republican because the Republican Party made me a man.”84 Clifford had mixed feelings about Christopher Payne, who delegates to the state Republican convention in May of 1888 elected to attend the national Republican convention. Although it was General Nathan Goff and Clifford who kept blacks from being denied participation in the convention, the Republican Party chose Payne as the standard bearer for African Americans in the state. After the convention, Clifford wrote:

We congratulate Rev. Mr. Payne, upon his successful election as delegate to the National Convention. We are not unmindful of the fact, nor should he be, that it was the result of our manly fight, through which a fragment of our power politically, was realized; and there would have been no trouble in getting one of the four elected at large, had there been unanimity to that effect. It is well enough to talk about having sufficient representation, when one has been elected. Such theory is pie for the whites but tough dough for the blacks. If all of the representation for the next ten years---county, state and national, were given us, and we were able to run things, we would not as much as get the interest on the principal. For one, like the whites, we are greedy. We solemnly aver, that if we can but see good colored men, though we differ widely, enjoy what we contend for, a thousand times will we be paid. ${ }^{85}$

Payne's selection was revealing. Eager to capitalize on the influx of the black workers coming into the

\footnotetext{
${ }^{83}$ Sheeler, “The Negro In West Virginia,” 210; Charles Edward Easton, “Negro Contributions to the Political and Legal History of the Southern Counties of West Virginia” (Master’s thesis, Marshall University, 1964), 66-67; and “Steve Elkins. ..," Weekly Register, September 12, 1888.

84 “We Were Surprised,” Pioneer Press, June 30, 1888.

85 “We Congratulate Mr. Payne,” Pioneer Press, May 30, 1888.
} 
southern part of the state, Republicans turned to loyal blacks in southern West Virginia to win the workers' votes, and it was those African Americans who were in position to take advantage of the opportunities afforded by the new Republican regime. ${ }^{86}$ Commenting on African Americans who were willing to accommodate white politicians for economic and political gain, Clifford stated in September 1888 that he pitied the "colored men of intelligence" who allowed white politicians to "embitter them against men who are brave enough to stem every current for the good of the race.” Clifford included himself among those men who were unwilling to abandon their principals for the "promise of a few crumbs.,"87

Clifford fully intended to challenge the status quo. In 1890, a white political leader in Jefferson County insisted, “all the trouble brewing in Jefferson is attributable to Clifford's paper and something must be done or the colored vote is lost.” As a result, four blacks were appointed to offices in Jefferson County in an attempt to keep the black vote and to "stop the mouth of the Pioneer Press.”88 Although Clifford often insisted he was getting entirely out of politics, he was quick to challenge those who questioned his political stance. When told there was a prevalent opinion that politically he carried "water on both shoulders," he stated, "a few, who can only believe that a colored man can't be trusted and naturally acts deceptively, disseminate such imaginable lies. We are frank to confess that, locally, we have cut off Republicans (?) and voted for Democrats, and we intend to do it whenever we choose to, and whose business is it?”89

The schism among blacks in West Virginia continued to grow throughout the 1890s. The majority of southern black leaders adopted Booker T. Washington's policy of accommodation and aided Elkins in his campaign to win black votes for the Republican Party. In return, the Republican Party in West Virginia offered blacks protection from the growing movement toward

\footnotetext{
${ }^{86}$ Sheeler, "The Negro in West Virginia,” 211.

87 “Colored Men of Intelligence,” Pioneer Press, September 28, 1888.

${ }^{88}$ Cleveland Gazette, January 4, 1890.

89 “Our Politics,” Pioneer Press, September 6, 1890.
} 
disfranchisement in the south. ${ }^{90}$ Republicans, who identified themselves with industrial progress and northern interests, were confident of gaining control of the state in the 1892 election. However, Democrats, in a direct appeal to the "southern element" in West Virginia, revived the issue of race and the fear of "Negro domination" that governed the 1888 election. Implying there was a Republican threat to the segregated school system, Democrats distributed a campaign cartoon that featured a black schoolteacher about to cane a small white child. The Democrats won the election. ${ }^{91}$

Charges of political corruption and the manipulation of black voters continued to appear in every election, reaching a climax in the pivotal 1896 election. That year, Democrats accused Republicans of bringing non-resident blacks into West Virginia counties that bordered on the Ohio River. In return, Republicans charged Democrats with scheming to arrest black voters on false charges to prevent their voting. As illustrated by the focus on illegal black voting in the southern counties in the 1888 election, the opening of the southern West Virginia coalfields created an important demographic and political shift in the state. By 1896, several former Democratic counties came under the control of railroad and coal men from other states, principally Pennsylvania and Ohio. Predominantly Republican, these capitalist entrepreneurs were natural allies of the new state Republican leader Stephen B. Elkins and presidential candidate William McKinley of Ohio because of their mutual support of the gold standard and high protective tariffs. By aligning with Elkins to win the state for the Republican Party, the southern coalfield men would have the ear of the man who ran the state government, while Elkins benefited from the security of a solid bloc of electoral support. ${ }^{92}$

\footnotetext{
90 “The Colored Voters Were Never So Divided,” Pioneer Press, September 28, 1888.

${ }^{91}$ Williams, Captains of Industry, 55.

${ }^{92}$ Williams, Captains of Industry, 55; Barbara Ann Ferrell, “West Virginia and the Election of 1896” (Master’s thesis, West Virginia University, 1967), 24.
} 
Bolstered by the votes of black industrial workers, the Republican Party succeeded in gaining control of the state in the 1896 election. In turn, the Republican victory profoundly affected black politics in West Virginia. After that election the balance of black political power rested in the southern counties rather than throughout the state. In 1896, the growing black electorate in Fayette County elected the first African American, Christopher H. Payne, to the West Virginia House of Delegates. Following the election, prominent African American leaders emerged from the counties of Fayette, Kanawha, and McDowell, counties with a rapidly growing number of black constituents. The rising number of African Americans in these counties combined with the absolute loyalty of black leaders such as Christopher Payne established a circle of dependency between white Republican coal operators and politicians, African American leaders, and the black working class that enabled operators to maintain control of the coal industry and provided opportunities for African Americans not available elsewhere in the south. Although black leaders justified their accommodation in the name of protecting their black constituents and the franchise, the votes of black miners also buttressed the emerging black middle class and promoted the influence and power of southern black leaders. ${ }^{93}$

Choosing confrontation over accommodation, Clifford continued to challenge discriminatory practices in West Virginia in the courtroom and in his paper. Using the Pioneer Press as a public forum, he called for immediate changes in the legal and social status of African Americans. In the courtroom, he fought for them. Yet his refusal to compromise with white political leaders made it impossible for him to exercise political leadership in West Virginia. Increasingly, black leaders in West Virginia, including many of Clifford's former co-editors, relied on white Republican leadership for patronage and protection, a position Clifford could not,

\footnotetext{
${ }^{93}$ Thomas E. Posey, The Negro Citizen of West Virginia (Institute, W.Va.: Press of West Virginia State College,
} 
and would not, accept.

1934), 38-39. 


\section{CHAPTER THREE}

\section{“DON'T FLINCH NOR YIELD AN INCH:” \\ The Struggle for Equal Rights}

“Being a member of the National Bar Association doesn't make a Negro any better or wiser, not certain that it helps cure the caste disease-better for them to work hard to meet and outstrip white lawyers_- 'especially those who 'don't like a Nigger.",1

Historian Paul Finkleman maintains that "every black defendant in the South faced allwhite juries, white judges who often called him 'nigger' or otherwise treated him with disrespect, and a system of justice skewed against him.”2 The same thing can be said about the black lawyers who challenged the status quo in an attempt to defend those clients. Black attorneys faced incredible obstacles in their quest for admission to the bar and once admitted, were often met with racism and discrimination so virulent that black lawyers were "assaulted, run out of town, or even killed” for practicing in the South. ${ }^{3}$ Finkleman describes early African-American lawyers as "social engineers," men who promoted social change and aided in the struggle for equality, consciously or unconsciously, through their determination to practice law despite intense prejudice and discrimination. ${ }^{4}$ Newspapers and journals of the era recognized the problems confronting black attorneys as they struggled to practice in America's courtrooms as well as the dangers the black community faced in the legal system without their presence. An article in the African Methodist Episcopal Church Review stated, “Admittedly, the Negro lawyer is at a serious disadvantage in practicing in the Courts in the Southern States and many places in the North. He cannot come into court and stand up as an advocate defending his cause and

\footnotetext{
${ }^{1}$ Pioneer Press, September 14, 1912. According to J. Clay Smith, the first African-American lawyer from West Virginia admitted to the National Bar Association was Thomas G. Nutter in 1929. Extremely successful, Smith reported that the group admitted Nutter although it had a ban on black members and that it was "not likely that the association was aware he was black.” See J. Clay Smith, Jr., Emancipation: The Making of the Black Lawyer (Philadelphia: University of Pennsylvania Press, 1993), 544.

${ }^{2}$ Paul Finkleman, “Not Only the Judges Robes Were Black: African American Lawyers as Social Engineers,” Stanford Law Review, 47: 161 (November 1994): 18.

${ }^{3}$ Finkleman, “Not Only the Judges Robes,” 19-20.
} 
exercising freely the prerogatives to which his admission to the bar entitles him.” Indeed, as an educated, intelligent, black man challenging the legal system in defense of his client, his very presence threatened the established social order. ${ }^{5}$ When J.R. Clifford passed the bar in 1887, he became one of only 440 African American lawyers in the United States, the majority of whom practiced in the North. Thirteen years after earning his law degree, Clifford was still one of only fourteen black lawyers in West Virginia; including several who had never practiced law. ${ }^{6}$

As J.R. Clifford began his effort to break down legal barriers to racial equality, he encountered numerous social, economic, and legal difficulties. Yet his traducers, and their repeated attempts to bribe, imprison, financially ruin, and physically harm him, only increased his determination to succeed. By 1890, Clifford lost all of his associate editors from across the state who wrote for his weekly newspaper, the Pioneer Press. Due to the lack of extant issues from this decade, it is unclear if their departure was due to other commitments, a mutual decision between Clifford and the men, or a consequence of the surging Republican Party under the direction of Stephen B. Elkins that afforded benefits to loyal black leaders and, therefore, led to an abandonment of the radical and independent editor. Clifford, suffering financially from continued attacks against both himself and the Pioneer Press and busy working to establish his law office, eventually named his friend and associate John W. Cromwell as co-proprietor and coeditor of the paper for the first few years of the decade. ${ }^{7}$

In addition to his personal struggles, the 1890s became a turning point for African Americans across the nation, particularly for those who lived south of the Mason-Dixon Line who

\footnotetext{
${ }^{4}$ Finkleman, "Not Only the Judges Robes,” 1-5.

${ }^{5}$ Finkleman, "Not Only the Judges Robes,” 1-5; African Methodist Episcopal Church Review, $29: 2$ (October 1912): 140.

${ }^{6}$ Smith, Emancipation, 625. Some African Americans in West Virginia, although admitted to the bar, never practiced law in the state. At least two worked as teachers or professors. On the other hand, Clifford, arguably the best-known lawyer in the state, listed his occupation as editor rather than attorney in the 1900 census.
} 
faced increasing attempts from local and state officials to legalize racial segregation. In 1883, the Republican dominated United States Supreme Court declared the Civil Rights Acts of 1875 designed to provide equal access to public facilities unconstitutional. Although the Republicans gained control of both the House of Representatives and the Senate in the 1888 election, Congress failed to pass the Henry Cabot Lodge’s “Force Bill” providing federal regulation of southern elections and protection for African-American voters. The "party of emancipation, equal rights, and free labor," as historian George M. Fredrickson points out, "was on its way to becoming the party of high tariffs, hard money, and big business.” Although the Republican Party continued to protest against violence and intimidation against blacks at the polls during elections and reward a few prominent African Americans with patronage jobs, Republicans no longer relied on the black vote to win elections and eagerly sought economic opportunities in the South. As a result, southern states devised "schemes to render the black vote ineffective" as the Republican Party increasingly abandoned its protection of black rights in the South. In addition to violence and intimidation, the south employed methods such as using alternate polling places, gerrymandering, poll taxes, confusing or complicated ballots, time restraints, and disqualification standards for those convicted of minor offences. ${ }^{9}$ In 1890, Mississippi revised its constitution and incorporated a suffrage amendment requiring a poll tax, disqualification for convicted "criminals," and the ability to read, understand, and interpret the state constitution, thereby eliminating the franchise for many poor and illiterate blacks. South Carolina added a similar amendment in 1895. In 1898, Louisiana enacted a new device called the "grandfather clause” into its constitution, allowing only those whose father and grandfather were eligible to vote as of January 1, 1867 to

\footnotetext{
${ }^{7}$ Pioneer Press, January 16, 1892.

${ }^{8}$ George M. Fredrickson, Black Liberation: A Comparative History of Black Ideologies in the United States and South Africa (New York: Oxford University Press, 1995), 30.

${ }^{9}$ John Hope Franklin and Alfred A. Moss, Jr., eds., From Slavery to Freedom: A History of African Americans
} 
register as voters. ${ }^{10}$ Clifford adamantly opposed the Louisiana law, stating “This editor’s grandfather had no rights, but he fought for his, and it is not what his grandfather was then, but what he is now."11

Along with the disfranchisement that occurred throughout the 1890s, the Supreme Court's rejection of the Civil Rights Acts of 1875 led to the passage of "Jim Crow" laws throughout the South. Although most southern states had laws restricting integrated schools and intermarriage, states began passing new laws requiring segregation in all aspects of public life, including railroad cars, hotels, restaurants, theaters, and streetcars. Attempts at white supremacy through legal segregation culminated in the United States Supreme Court decision Plessy v. Ferguson in 1896. ${ }^{12}$

In 1892, Homer Plessy, in a planned challenge to the 1890 Louisiana Separate Car Act, purchased a first-class ticket on the East Louisiana Railway in New Orleans knowing that the company only provided third-class cars to African Americans. Backed by a Committee of Citizens, a group of eighteen black professionals in New Orleans determined to overturn the act, Plessy refused to leave his seat in the designated "white” car. Arrested and fined, Plessy challenged the segregation law in the Louisiana District Court. After the court ruled that the Louisiana Constitution had the power to regulate railroads within its own boundaries and was, therefore, constitutional, Plessy appealed the case to both the Louisiana State Supreme Court and

(New York: McGraw Hill, Inc., 1994), 254-263.

${ }^{10}$ Franklin and Moss, From Slavery to Freedom, 254-263.

${ }^{11}$ Pioneer Press, May 1911.

${ }^{12}$ Pioneer Press, May 1911. Segregation occurred in the antebellum North between blacks and whites and laws for racial segregation appeared early in the Reconstruction South as whites attempted to keep the races completely separate. After disappearing circa 1868, several southern states attempted to institute legal segregation as conservatives "redeemed" the South. Although many southern states passed laws against intermarriage and integrated schools, widespread attempts at legal segregation did not appear until the Supreme Court deemed the Civil Rights Acts of 1875 unconstitutional in 1883. With the creation of new constitutions in the 1890s, southern states also began trying to establish stringent segregation of the races that culminated in the Supreme Court decision Plessy v. Ferguson that upheld the doctrine of "separate but equal" in 1896. See Franklin and Moss, Chapter 13. 
the United States Supreme Court. In May of 1896, the United States Supreme Court upheld the Louisiana mandate for “separate but equal” cars, a decision that justified legal segregation in America for the next fifty-eight years. ${ }^{13}$

Despite the deterioration in race relations and the growing discrimination against black Americans throughout the 1890s, it was in this decade that J. R. Clifford fought his most significant cases and made considerable strides in his reputation as a lawyer. Indeed, the election year of 1892, marked by Plessy's challenge to segregation, was a particularly busy year for Clifford. In addition to publishing the Pioneer Press and participating in political campaigns, the year marked the beginning of a series of contentious legal battles that led Storer College's newspaper, the Storer Record, to report in January 1893 that Storer College alumni John R. Clifford was "winning laurels in the circuit courts of Berkeley County.”14

In February 1892, J.R. Clifford became the first African American to practice law before the Allegeny County Bar in Cumberland, Maryland when he defended Harry Green for the murder of Charles Ross at Westernport, Maryland. ${ }^{15}$ The jury found Green "not guilty” in the April term, a considerable victory for the first appearance of a black lawyer before the Allegeny County bench in defense of a black client. Clifford certainly recognized the significance. Earlier, the courts in nearby Hagerstown, Maryland only admitted friend and fellow Storer alumni John Frank Wheaton to the bar on the condition that he would not be allowed to practice there. Western Maryland did not have a reputation for its hospitality to African American lawyers. ${ }^{16}$ That spring, Shaw University in Raleigh, North Carolina, recognized Clifford’s success as an

\footnotetext{
${ }^{13}$ Plessy v. Ferguson 163 U.S. 537 (1896) No. 210; Keith Weldon Medley, We As Freemen: Plessy v. Ferguson (Gretna, La.: Pelican Publishing Company, Inc., 2003), 14.

14 “Among Former Pupils," Storer Record, (Winter 1893): 1.

${ }^{15}$ The Herald and Torch Light, April 28, 1892.

${ }^{16}$ J.R. Clifford in the Richmond Planet, January 28, 1899. J. Frank Wheaton (1866-1938) moved to Minnesota in 1890 where he became the first African American elected to the Minnesota House of Representatives in 1898.
} 
editor, lawyer, and civil rights activist when it awarded him an Honorary Degree (A.B.). ${ }^{17}$

Yet despite his achievements, Clifford's battle for political and civil rights was just beginning. An election year, racial tension steadily increased during 1892 as West Virginia Democrats waged a bitter race campaign based on the threat of desegregated schools and the fear of “Negro domination.” Democrats targeted Hamilton Hatter, a black instructor at Storer College, who was a candidate on the Republican ticket for the legislature from Jefferson County. His chances of winning were "exceedingly bright," a fact that led his opponents to circulate lithographs portraying an integrated schoolroom under the instruction of a "burly Negro.” The images of the black children, like their teacher, personified nineteenth century stereotypes of African Americans. In the poster, the teacher brutally chastised a beautiful white girl as "Negro" pupils laughed with ghoulish glee. Intelligent white voters of Jefferson County were told to expect a similar state of affairs throughout the state if Hamilton Hatter were elected to the legislature. ${ }^{18}$

By cultivating an atmosphere of racial animosity, the Democratic campaign was a success. Not only did Hatter lose the election, Democrats maintained control of the state government. However, Berkeley County voters did elect a young white Republican named U.S.G. Pitzer as Prosecuting Attorney that fall. In October of 1892, Clifford, Hatter, and Pitzer were guest speakers at a Republican club in Jefferson County called the "Harrison, Reid, and Hatter" Club. ${ }^{19}$ Clifford was politically active throughout the election, but his mind and his heart were busy contemplating the discrimination black children faced in the state’s "separate and un-equal”

\footnotetext{
Hagerstown, Maryland is less than twenty miles from Martinsburg, West Virginia.

${ }^{17}$ Catalogue of the Officers and Students of Shaw University, 1892-1893 (Raleigh: Shaw University Printing Department, 1893).

${ }^{18}$ Charleston Advocate, August 13, 1908.

${ }^{19}$ Wheeling Daily Intelligencer, October 31,1892. Pitzer worked with J. Nelson Wisner at the Martinsburg Independent and began studying law with Wisner in 1886.
} 
schools, a condition he believed disregarded their constitutional rights and caused immutable damage to African Americans. Years earlier, Clifford had doubts about integrated schools, claiming that some newspapers, such as the Catholic Tribune, "advocated 'mixed schools' a quarter of a century ahead of time" and that "thousands of people who depended on teaching for a living will not recover." However, the discrepancies between black and white schools and the lack of quality education available for black children altered his stance, and Clifford intended to challenge those disparities in a court of law. ${ }^{20}$

In segregated schools, “inequities persisted and increased,” and marked African Americans with a "badge of inferiority" that was difficult to overcome. ${ }^{21}$ Circumstances, along with a little maneuvering on Clifford's part, provided him with the perfect opportunity to contest the segregated school system in the fall of 1892. The Fairfax District Board of Education in nearby Tucker County, in an effort to cut costs, limited the black schoolhouse located in Coketon to a term of five months while allowing the white schools to maintain eight month terms. School boards throughout the south frequently attempted to slash funding to both black and white public schools, although expenditures were cut as far as possible in black schools long before the board turned to the white schools. ${ }^{22}$ Undeniably, the practice occurred so often in southern states that it is doubtful if Tucker County was the only place in West Virginia where this occurred, despite laws to the contrary.

Tucker County, a land of rugged and mountainous terrain situated on the Allegheny Plateau, was a focal point of the timber and coal industry in West Virginia. In 1899, the construction of the West Virginia Central and Pittsburgh Railway across the county, linking the

\footnotetext{
${ }^{20}$ Pioneer Press, July 1887.

${ }^{21}$ John Hope Franklin, “Jim Crow Goes to School: The Genesis of Legal Segregation in Southern Schools, South Atlantic Quarterly, 58:2 (Spring 1959): 225-235.

${ }^{22}$ Franklin, “Jim Crow Goes to School,” 225-235; Williams v. Board of Education of Fairfax District, Tucker
} 
timber and coal industries to the mainline of the Baltimore \& Ohio Railroad, led to increased development and economic expansion. Tucker County’ population more than doubled in ten years, from 6,459 people in 1890 to 13, 4333 in 1900. Included in the influx of timber workers and coal miners were a number of African-American workers and their families who increased the black population from 183 to 253 within those same ten years. The majority of those African Americans lived in Coketon, a coal mining town run by Davis Coal and Coke. In this case, the Fairfax District School Board in Tucker County hired an African American school teacher named Carrie M. Williams to teach at the black school at Coketon. Carrie Williams was a twenty-six year old mother of two and pregnant with her third child. Her husband, Abraham, was a coal miner. ${ }^{23}$ Williams had taught for nearly ten years in Ohio and West Virginia, including the last several years at Coketon, without any problems from the local school board, parents, or pupils until the 1892-1893 school year. Carrie Williams was fully aware that all schools in Tucker County, black and white, normally ran for eight months, yet school officials expected her to tacitly accept the shorter term. ${ }^{24}$ As a company town, more than likely board members assumed that the African American workers and their families, including Carrie Williams, would be too intimidated to protest the board's new policy. After all, the company that provided the schools and ran the school board also paid their wages and gave them housing, a situation that basically rendered them helpless against the board's new policy. ${ }^{25}$

Still, Carrie Williams refused to acquiesce. When presented with a teaching contract calling for a term of five months that fall, she refused to sign it. In court, Williams later testified,

\footnotetext{
County.

${ }^{23}$ Twelfth Census of Population 1900, Tucker County, West Virginia; Thirteenth Census of Population 1910, Tucker County, West Virginia.

${ }^{24}$ Minutes of the Fairfax District Board of Education 20 July 1892, Tucker County Board of Education, West Virginia.

${ }^{25}$ Paul I. Clifford, “Certain Dimensions of the Life and Times of J.R. Clifford,” 24, PMWCP.
} 
"I knew the white school term was eight months, and I saw counsel and went on." ${ }^{26}$ The counsel was J.R. Clifford. Clifford now had a legal case against the segregated school system to take before the court, a courageous plaintiff who was willing to pursue it, and, in what was either a timely coincidence or a very well thought out plan, a sympathetic judge. The judge for the Third District Court of West Virginia was Martinsburg native and Storer College advocate, the Honorable Joseph T. Hoke. ${ }^{27}$ Clifford advised Williams to teach the same number of months as the white schools, a full eight months. At the end of the school year, Williams was to present the board with a bill for the final three months’ wages, $\$ 120.00$ dollars. If the board failed to pay Williams for her services, Clifford would then file a suit on her behalf on the basis of illegal discrimination. $^{28}$

Meanwhile, Clifford faced the new prosecuting attorney, U.S.G. Pitzer, twice in the January 1893 session of the Circuit Court. In the first case, Clifford defended William Redmond who was indicted for horse-stealing. The Martinsburg Independent described the trial as "hotly contested,” with Clifford putting on a stubborn defense. After the attorneys presented their arguments, the jury failed to agree on a verdict. However, the court convicted and sentenced Redmond to six years in the penitentiary after retrying the case the following week. In the second trial, Clifford and a white lawyer, F. Vernon Aler, represented Edward Murphy against the charge of perjury in a shooting case. Once again, the jury could not agree on a verdict and dismissed the case after "highly dramatic and sensational arguments"29 Referring to Pitzer in the following issue of the Pioneer Press, Clifford stated, “There can be no fault found with the above county official for not discharging his whole duty in prosecuting crime. He is a hard student, a forcible

\footnotetext{
${ }^{26}$ Williams v. Board of Education of Fairfax District 45 W.Va. 199, 31 S.E. 985 (1898). Author's emphasis on "I saw counsel."

${ }^{27}$ Williams $v$. Board of Education.

${ }^{28}$ Williams v. Board of Education.
} 
speaker, and it will only require time for the state and nation to know and applaud." ${ }^{30}$ Clifford appeared both respectful and encouraging to the young attorney, a prominent member of the Berkeley County Republican “ring.”

As it turned out, Clifford's first legal challenge against the segregated school system in West Virginia began on March 23, 1893, when he filed a petition and application for a writ of mandamus for Thomas Martin against the Board of Education and Trustees of Cacapon District, Sub-District No. 4, of Morgan County stating that the educational authorities had engaged in “direct violation of the $14^{\text {th }}$ Amendment of the Constitution of the United States" which prohibits the states from abridging the "privileges or immunities of citizens of the United States” or depriving “any person of life, liberty, or property without due process of law” or denying "any person "the equal protection of the laws.” Clifford claimed that the state of West Virginia had enacted an invalid law by prohibiting attendance of black and white children in the same school. ${ }^{31}$

In this case, public school officials in Morgan County refused to admit the five children of Thomas and Louisiann Martin to the Camp Hill School located outside the town of Paw Paw, West Virginia. The teacher, (Mr.) M.A. Vanorsdale, turned away Samuel, Phillip, Fenton, Rachel and Nancy when they presented themselves at the schoolhouse on January 23, 1893, and “demanded admission and to be taught therein with the white children as they were and are of right entitled.”32 Thomas Martin was a well-known resident of the township, a farmer who often took his produce to Cumberland, Maryland via the Chesapeake \& Ohio Canal and always paid his taxes. A former Civil War veteran who rose to the rank of sergeant in the Union Army, Martin was self-educated and active in the community as a founder and trustee of the Mt. Olive Church

\footnotetext{
29 “Trials in the Circuit Court,” Martinsburg Independent, January 28, 1893.

${ }^{30}$ Martinsburg Independent, February 11, 1893.

${ }^{31}$ Petition to Hon, E.B. Faulkner, Judge of the Circuit Court of Morgan County State of West Virginia,” March 23, 1893, Martin v. Board of Education, 42 W.Va. 514, 26 S.E. 348 (1896).
} 
as well as a member of both the Odd Fellows and the Masons. ${ }^{33}$

Clifford argued the test case on May 5, 1893, before Judge E. Boyd Faulkner in Berkeley Springs, West Virginia. The opposing counsel was Clifford's former adversary, W.H.H. Flick. Clifford, on behalf of Thomas Martin, asked the court to grant an order compelling the Morgan County Board of Education to admit black scholars to certain schools, particularly when districts failed to provide schools for African Americans. The case sparked widespread interest across the state, particularly after the previous election and the race baiting campaign based on "mixed schools.” Faulkner's decision held that the constitution of West Virginia forbade mixed schools and that the state Constitution superseded the Fourteenth Amendment, a decision that was met with general approbation among whites. ${ }^{34}$ Faulkner, the descendant of an influential ante-bellum family and a former Captain in the Confederate Army, denied the request based on two reasons: the West Virginia Constitution and "for other reasons which it is unnecessary to mention.”35 While Clifford argued the Martin case, Carrie Williams continued to teach at the black school in Coketon. When school ended in June, Williams presented the school board with a bill for her extra three months of service. As expected, the board refused to pay Williams, claiming that she continued to teach although she knew the contract presented to her called for a five month term. Clifford, however, insisted Williams had the right to be paid for all eight months and on June 30, 1893, he and A.G. Dayton, a prominent and influential Republican attorney in Tucker County, filed a lawsuit against the Fairfax District Board of Education on behalf of Williams. ${ }^{36}$ It was common practice at that time for black lawyers to designate a white attorney as their

\footnotetext{
${ }^{32}$ Petition to Hon, E.B. Faulkner, Judge of the Circuit Court of Morgan County State of West Virginia.”

${ }^{33}$ Martin vs. Board of Education.

34 “Mixed Schools in West Virginia,” Martinsburg Independent, May 6, 1893; “Judge Faulkner Against Mixed Schools,” Martinsburg Independent, May 13, 1893; Martin v. Board of Education.

35 "Judge Faulkner Against Mixed Schools."

${ }^{36}$ Williams v. Board of Education.
} 
associate, but Dayton did not actually participate in the case. In a letter to the court Clifford maintained that he "was the only attorney in the case" and in a postscript added, "Dayton's name appears in the record only through an act of courtesy., ${ }^{37}$

On August 2, 1893, Clifford received a letter from H.J. Meyer, Secretary of the Tucker County Board of Education, written on Davis Coal and Coke Company stationary warning him against taking legal action in the Carrie Williams case: "If you undertake to prosecute her claim I would advise you to collect your fees in advance, for if you take it on commission it will very likely prove a losing investment." ${ }^{38}$ Although Meyer appeared to be pointing out the economic losses that Clifford would incur, the underlying threat was the power of Davis Coal and Coke as an opponent, a fact Meyer clearly hoped would intimidate Clifford. Clifford certainly was not afraid of a financial loss; he faced that prospect daily with the Pioneer Press. If Meyer intended to use Davis Coal and Coke to deter Clifford from his cause it was a mistake; intimidation never worked on Clifford. In November of 1893, Clifford filed a lawsuit on behalf of Williams claiming the Fairfax District School Board owed Carrie Williams $\$ 120.00$ for teaching the colored school at Thomas for three months and one dollar that was withheld from her monthly wages for not making out a report. ${ }^{39}$ However, Clifford and Williams would have to wait for two years before their case finally appeared before the circuit court.

In March of 1894, Clifford again faced U.S.G. Pitzer in a court of law. However, in this case Clifford was the plaintiff against Aaron Crim who, Clifford maintained, caused the death of his horse. Clifford asked for \$150.00 in damages. J. Nelson Wisner represented Clifford and Pitzer defended Crim. Clifford lost, but not without a fight; newspapers referred to the case as "a

\footnotetext{
${ }^{37}$ Williams v. Board of Education.

${ }^{38}$ Letter from H.E. Meyer to J.R. Clifford, 2 August 1893. Williams v. Board of Education.

${ }^{39}$ Williams $v$. Board of Education.
} 
lively contest. ${ }^{40}$ Despite a series of hotly contested legal battles with Pitzer and his animosity toward Republican leaders in Berkeley County, particularly George F. Evans and W.H.H. Flick, Clifford remained active in Republican Party politics. In doing so, Clifford often came face to face with his opponents. In a case of "politics make strange bedfellows," in May of 1894 the Second Ward Republican Club of Martinsburg elected Clifford as an alternate to the Convention of Republican Clubs of West Virginia scheduled to meet in Fairmont in June 1894. Among the delegates elected to the convention were U.S.G. Pitzer and George F. Evans. ${ }^{41}$ Clifford was also among the sixty-nine delegates from Berkeley County elected to attend the District Congressional Convention in Elkins in September in which Clifford and Washington Corsey were the only two African Americans elected from the county. Among the other delegates, once again, were U.S.G. Pitzer, George F. Evans, and W.H.H. Flick. ${ }^{42}$ Mrs. Stephen B. Elkins hosted a reception for the delegates, an occasion that sparked political conflict in Martinsburg. The Martinsburg Herald printed a list of delegates who attended the reception and omitted the names of Clifford and Corsey, leading the Martinsburg World to inquire if the "colored brothers who fight so nobly at the polls were ignored in the distribution of favors.” Their attempt to alienate blacks from the Republican Party failed when J. Nelson Wisner reported that both were invited to attend the affair and that although Corsey left with other delegates from Berkeley County, Clifford attended the reception and stayed over night as well. ${ }^{43}$

In addition to running his paper, practicing law, and participating in political activities, the trustees of the Manassas Industrial School in Virginia elected Clifford as principle of the school in September of 1894. Clifford's service at the school is unclear. R. Worth Peters states in

\footnotetext{
${ }^{40}$ Martinsburg Independent, March 31, 1894.

${ }^{41}$ Martinsburg Independent, May 31, 1894.

${ }^{42}$ Martinsburg Independent, August 11, 1894.

43،Not Thusly," Martinsburg Independent, September 16, 1894. Hallie Davis Elkins was the daughter of Henry
} 
Secondary Education in Manassas, Virginia, 1890-1935 that Clifford was principal of the school from 1894 to 1900. He maintains that the trustees chose Dr. Elijah P. Clemens as the first principal, but that he withdrew from his contract before the school opened and never served. ${ }^{44}$ However, in Undaunted Faith: The Life Story of Jennie Dean, Stephen Johnson Lewis claims Clifford, although listed as the first principal, never actually served. Lewis maintains Clemens took over the duty, although neither Clemens nor Clifford attended the dedication services. ${ }^{45}$ According to John W. Cromwell, Clifford did serve as principle of the Manassas Industrial School, although he later resigned following "his contention for better water." ${ }^{46}$ Clearly, Clifford had very little time to accord to the school. Not only did Clifford continue to reside in Martinsburg, he was still actively engaged in the Martin and Williams cases.

On May 1, 1895, Clifford submitted his petition for a writ of error and supersedes from the Circuit Court of Morgan County on the Martin case. The West Virginia Supreme Court of Appeals agreed to hear the case and scheduled the hearing for a year and a half later on September 4, 1896. In his brief Clifford stated, "If the mere provision to set aside a fund for colored children means a 'thorough and efficient system of free schools' then the definition of the words 'thorough and efficient' have lost their meaning as laid down by the benefactor of free schools, Noah Webster.” Clifford based the case on a violation of property and being deprived of the "due process of law." ${ }^{\text {47 }}$ Clifford's argument in the Martin case stemmed from his interpretation of the rights afforded to American citizens under the Fourteenth Amendment. A great admirer of attorney Roscoe Conkling who argued in 1882 that "Those who devised the $14^{\text {th }}$ Amendment . . . builded not for a day, but for all time; not for a few, or for a race; but for man,

Gassaway Davis who owned the Davis Coal and Coke Company.

${ }^{44}$ R. Worth Peters, Secondary Education in Manassas, Virginia, 1890-1935 , 72, 158.

${ }^{45}$ Stephen Johnson Lewis, Undaunted Faith: The Life Story of Jennie Dean, 44.

${ }^{46}$ John W. Cromwell, “Communications,” Journal of Negro History, XIII No. 3 (July 1923), 338-340. 
they planted in the Constitution a monumental truth ... that truth is but the golden rule, so entrenched as to curb the many, who would do to the few as they would not have the few do to them," Clifford firmly believed that if the courts enforced the true intent of the Fourteenth Amendment, civil rights for all Americans would be protected. ${ }^{48}$

Following his appeal to the West Virginia Supreme Court of Appeals in the Martin case, Clifford argued a case in the Berkeley County courtroom that September which ended not only in his contention for the right of African Americans to serve on juries, but for his life as well. Clifford's actions went unnoticed that September, for the nation's eyes were on another African American who grew up in West Virginia, Booker T. Washington. On September 18, 1895, Washington delivered a speech at the Cotton States and International Exposition held in Atlanta, Georgia intended to quell white fears of social equality. His speech, later described as the "Atlanta Compromise," made Washington the preeminent black leader in America following the death of Fredrick Douglass in February of 1895. Washington called for African Americans and whites alike to "cast down their buckets where you are," encouraging blacks to remain in the South and whites to look to their loyal black population as a labor force, while assuring his predominantly white audience that in "all things purely social we can be as separate as the fingers. $" 49$

While Washington was in Atlanta, John Robert Clifford was standing in a courtroom in Martinsburg, West Virginia, attempting to empanel African Americans on a jury. Although the 1879 Supreme Court decision Strauder v. West Virginia gave blacks in West Virginia the right to serve on juries, most counties in West Virginia still refused to let African Americans serve.

\footnotetext{
${ }^{47}$ Martin v. Board of Education.

48 "Roscoe Conkling," Pioneer Press, April 30, 1888; and Oral Argument of Roscoe Conkling, San Mateo County v. Southern Pacific Railroad, 116 U.S. 138 (1882), 31-32.

${ }^{49}$ Booker T. Washington, Up From Slavery: An Autobiography (New York: Doubleday and Co., Inc., 1963), 157-
} 
Clifford's stubborn and continued demand for black jurors in defense of his client's rights frustrated Prosecuting Attorney U.S.G. Pitzer, who picked up weights from the bench and struck Clifford three times until his blood ran in his shoes and he fell to the floor. Pitzer then jumped on top of Clifford as the courtroom emptied and the two men wrestled until Clifford pinned Pitzer to the floor. At that point, an African American named Stephen Elam ran into the room and pulled Clifford off of Pitzer. Most likely, Elam feared that if Clifford killed Pitzer, he would be dangling from a tree.$^{50}$ Following the altercation, Clifford rushed home, had his wounds dressed, changed his shirt, and returned to the courtroom to argue the case. Clifford succeeded in his contention for a mixed jury; however, he lost the case due to an arbitrary ruling of the court. ${ }^{51}$

Clifford's friend and fellow editor, John Mitchell, Jr., reported the physical attack in Richmond Planet stating, "We regretted to learn of the injury sustained by our brilliant legal friend, J.R. Clifford, Esq., editor of the Martinsburg, W.Va., Pioneer Press at the hands of the commonwealth's attorney of Berkeley County. The failure of the Justice to protect Mr. Clifford is as mystifying as the attack itself. We presume the matter will not rest here and shall watch with interest the result of the controversy.” Although no mention of the attack or any legal or vocal reprimand of Pitzer appeared in the Martinsburg newspapers, Clifford had no intention of letting the matter rest and he was willing to wait for the opportunity to apply justice. ${ }^{52}$

That same fall, C.O. Strieby, attorney for the Fairfax District Board of Education, submitted arguments to the Circuit Court of Tucker County in lieu of a jury trial. On hearing the evidence, Judge Joseph T. Hoke ruled in favor of Carrie Williams and ordered the Board to pay Mrs. Williams $\$ 139.00$ plus legal fees. Although Strieby asked the court to set aside the findings

\footnotetext{
160.

${ }^{50}$ Pioneer Press, September 9, 1911. Elam was a fifty-seven year old day laborer from Martinsburg.

${ }^{51}$ Richmond Planet, November 23, 1895.

52 Richmond Planet, December 17, 1898. According to Clifford's pension file, he suffered permanent nerve damage
} 
and award his client a new trial, Judge Hoke overruled his motion, giving Clifford and Williams a long-awaited victory. Despite the hard work and the physical injuries he sustained in the process, Clifford succeeded in his effort to challenge both all white juries and segregated schools. However, Clifford's victory was short-lived; the Fairfax District Board of Education quickly appealed Judge Hoke's decision to the West Virginia State Supreme Court. ${ }^{53}$

The following year, Clifford became the first African-American lawyer to appear before the West Virginia Supreme Court when he argued the case Martin v. Board of Education before the Court in September of 1896. In the Martin case, Clifford contended that "When a State Legislature enacts a law setting aside funds in proportion to the existing number of White and colored people, in which discrimination will give excellent school facilities to the Whites and inferior to the blacks, it is contrary to the $14^{\text {th }}$ Amendment and void. ${ }^{, 54}$ Although Clifford admitted that Article XII, Section 8 of the West Virginia Constitution of 1872 declaring that "white and colored persons shall not be taught in the same school" was settled law, he maintained that the Fairfax District Board of Education failed to provide equal facilities and, therefore, the Martin children were entitled to attend the school provided for white children. The Martin case was the first legal attack on segregated public schools in West Virginia and certainly one of, if not the first, legal challenges to segregated schools in the South. However, the West Virginia Supreme Court of Appeals maintained that the West Virginia Constitution held dominance over the Fourteenth Amendment to the United States Constitution, and that to rule in Martin's favor would be "permitting the neglect of the legislature or board of education to abrogate the state Constitution, while it is the paramount duty of this Court to see that they obey it.” The State

\footnotetext{
from the blows to his head.

${ }^{53}$ Williams v. Board of Education.

${ }^{54}$ Martin v. Board of Education; also see Douglas c. Smith, "A West Virginia Dilemma: Martin v. Board of Education, 1896,” West Virginia History, Vol. 40, Number 2 (Winter 1979): 158-163.
} 
Supreme Court upheld the lower court of Judge Faulkner and ruled against Martin. In doing so, Judge Marmaduke Dent opined, “Social equality cannot be enforced by law.” Despite his failure to overturn the West Virginia law mandating blacks and whites must be taught in separate schools, Martin still managed to achieve a victory. The Morgan County Board of Education, after fighting a very public and costly case, built a school for African Americans. ${ }^{55}$

Decided four months after the United States Supreme Court handed down its decision in Plessy v. Ferguson, it is not surprising that the West Virginia Supreme Court ruled against Clifford, just as the Louisiana State Supreme Court ruled against Albion Tourgee earlier in the Plessy case. Both cases questioned laws mandating racial segregation in their respective states, challenging each state's constitutional right to legislate and enforce segregation. In addition, both of the attorneys representing Plessy and Martin, Tourgee and Clifford, argued that the segregation laws placed into the state constitutions were unconstitutional infringements on their clients' privileges under the equal protection clauses of the Fourteenth Amendment to the Constitution. However, in both cases, the courts ruled that the states remained within their constitutional boundaries and, therefore, upheld the states' segregation laws. Perhaps the earlier United States Supreme Court decision in Plessy v. Ferguson portended the outcome of Martin v. Board of Education for Clifford. One thing that the decision in Plessy v. Ferguson made perfectly clear was that if the West Virginia Supreme Court upheld the circuit court decision in Martin v. Board of Education, Clifford had no recourse for an appeal. ${ }^{56}$

The point of law Clifford argued in Martin v. Board of Education would not be settled until fifty-eight years later on May 17, 1954, when the United States Supreme court handed down

\footnotetext{
${ }^{55}$ Martin v. Board of Education.

${ }^{56}$ Martin v. Board of Education; Plessy v. Ferguson. Segregated schools in West Virginia were not challenged again until 1913 when African-American attorney James Graham, Jr. of Wheeling, W.V. argued the case Steele v. Board of Education of Hancock County. Graham lost the case in circuit court and there is no record of an appeal.
} 
their ruling in Brown v. Board of Education of Topeka, thereby overturning the 1896 decision in Plessy v. Ferguson. Although Clifford did not use the same words, his legal concepts and conclusions were remarkably similar to those used in the Brown case. As in the now famous 1954 Brown v. Board of Education, Clifford argued that despite the concept of "separate but equal,” separate was never equal. Judge Earl Warren of the United States Supreme Court arrived at the same conclusion in the Brown v. Board of Education ruling when he wrote, "Separate education facilities are inherently unequal,” and that they deprived citizens of the "equal protection of the laws guaranteed by the Fourteenth Amendment.” Judge Warren maintained that “To separate children from others of similar age and qualifications solely because of their race generates a feeling of inferiority as to their status in the community that many affect their hearts and minds in a way unlikely ever to be undone," a sentiment similar to the one Clifford expressed in $1892 .^{57}$

Despite Clifford’s loss, John Mitchell, Jr., later reported in the Richmond Planet that Clifford “certainly makes himself heard.” Although Mitchell felt the Republican Party should recognize and honor Clifford with a political appointment for his service to his people as well as the party, he recognized the improbability of that occurring. Claiming "Mr. Clifford is too independent” and “far better off as a poverty-stricken, but free mountaineer, [rather] than a well clad slavish office-holder, with no hope for the future beyond the monthly allowance from the national crib,” Mitchell predicted “his day of recognition will yet come.”58

The following year, on June 11, 1898, Clifford submitted his brief in the Williams $v$. Fairfax District Board of Education before the West Virginia Supreme Court. Once again, he found himself before Judge Marmaduke Dent, the justice who handed down the State Supreme

${ }^{57}$ Brown v. Board of Education of Topeka, 347 U.S. 483 (1954). 
Court's decision against him in Martin v. Board of Education. Clifford argued that Judge Hoke's original ruling in the Circuit Court of Tucker County should stand. Claiming, by law, boards of education could waive a written contract with a teacher, and that if it chose to do so, and still received the benefit of their teaching, the board was required to pay for their services even without a contract. Indeed, the law justified Carrie Williams' decision not to sign a contract that violated the purpose and intent of the West Virginia Constitution calling for "separate but equal" schools. In opposition, C.C. Strieby, arguing for the Fairfax District Board of Education, stressed three major points: Carrie Williams had no written contract; that there can be no implied contract under state law; and that the three months pay Williams was seeking was not owed to her since she voluntarily taught school for those months. ${ }^{59}$

Justice, as well as the recognition that Mitchell predicted, finally came in the fall of 1898. In a move calculated to irritate Pitzer who was running on the Republican ticket for Congress, in August 1898 Clifford announced that he also was candidate for Congress. ${ }^{60}$ That fall, as election day came near, Clifford took the shirt he was wearing three years earlier when U.S.G. Pitzer attacked him in the courthouse and canvassed the county on his bicycle, waving the blood-stained shirt for everyone to see. The day before the election, Clifford spoke for an hour and twenty minutes from inside the band stand in the public square, once again criticizing Pitzer and waving the bloody shirt. Of course, Clifford did not win the election; but neither did Pitzer. Henry S. Cushwa, the democratic candidate, defeated Pitzer by more than 1300 votes—just as Clifford intended. ${ }^{61}$

The Democratic Martinsburg Statesman reported that Pitzer waged a heroic fight, but a

\footnotetext{
${ }^{58}$ Richmond Planet, February 6, 1897.

${ }^{59}$ Williams $v$. Board of Education.

${ }^{60}$ Martinsburg Herald, August 20, 1898; Richmond Planet, September 3, 18/98.

${ }^{61}$ Pioneer Press, September 9, 1911.
} 
well organized Democratic Party along with "the odium of the Ring” and being "stabbed in the back in the house of his pretended friends” led to defeat. Claiming that the people administered "a rebuke to the arrogant court house ring and the colored people did their full share," the Statesman declared that many blacks "have at last come to their senses and have decided to be free men, to vote like white people and to no longer be the tools and slaves of the white Republican bosses. $^{62}$ Numerous blacks in the eastern panhandle did, in fact, oppose the local Republican “ring,” but it was Clifford who swayed the black vote and it had nothing to do with party politics. It was purely personal.

Following Pitzer's defeat, Clifford reprinted the article that appeared in the Richmond Planet after Pitzer's physically attacked him in 1895. Mitchell ended his column with statement "we shall watch with interest the result of the controversy." Below the reprinted article, Clifford asked, “Brother Mitchell, have you watched and seen to your heart’s delight?”63 Clifford had his justice ... and he kept the bloody shirt as a souvenir.

While Clifford reveled in his blow to Pitzer's political career, the West Virginia Supreme Court came to a decision in the Williams case. On November 16, 1898, the West Virginia Supreme Court of Appeals upheld the Circuit Court's decision in Williams v. Board of Education, ruling in favor of Carrie Williams. In doing so, Judge Marmaduke delivered the majority opinion. Dent's language was surprising. He dismissed the board's argument based on the absence of a written contract stating:

After the service has been rendered in a satisfactory manner to the patrons of the school, and the board has recognized and approved it by receiving her monthly reports, and paying her five months' salary, it is too late for them to object that her appointment was not in writing. ${ }^{64}$

\footnotetext{
${ }^{62}$ Martinsburg Statesman, November 9, 1898.

63 "We Have Watched," Pioneer Press from the Richmond Planet, December 17, 1898.

${ }^{64}$ Williams $v$. Board of Education.
} 
Addressing the Fairfax District Board of Education's attempt to impose an arbitrary five month term on black pupils while funding eight months of education for white students, Dent wrote, "This distinction on the part of the board, being clearly illegal, and a discrimination made merely on account of color, should be treated as a nullity, as being contrary to public policy and good morals. ${ }^{, 65}$ In what appears to be a liberal statement for a state south of the Mason-Dixon Line in 1898, and contrary to the rising tide of racism, discrimination, violence, and segregation aimed at African Americans, Dent maintained:

If any discrimination as to education should be made, it should be favorable to, and not against, the colored people. Held in the bondage of slavery, and continued in a low moral and intellectual condition, for a long period of years, and then clothed at once, without preparation, with full citizenship, in this great republic, and the power to control and guide its destines, the future welfare, prosperity and peace of our people demand that this benighted race should be elevated by education, both morally and intellectually, that they may become exemplary citizens; otherwise the perpetuity of our free institutions may be greatly endangered. ${ }^{66}$

Dent's statement, while open-minded and contrary to the opinion of most southern whites, was also a reflection of the times. For it reflects the "white man's burden," the moral obligation and social responsibility of those of high rank or birth (whites) to elevate those of lower status (blacks). Paternalistic at best, Clifford must have found the statement condescending; nevertheless, it afforded him a victory in his fight for equality in public schools. While the decision did not overturn West Virginia's law for the separation of black and white children in state's schools, it did require that the schools be equal according to West Virginia law. Clifford's victory forced school boards to provide equal school terms and equal pay for teachers regardless of color. These provisions not only attracted many black migrants from the south to the coalfields of West Virginia with the promise of a better education for their children, but also drew well-

\footnotetext{
${ }^{65}$ Williams v. Board of Education.

${ }^{66}$ Williams v. Board of Education.
} 
educated and well-qualified black teachers into the state, forcing surrounding states to provide better pay as well. At the same time, the law failed to provide equality for black pupils in the quality and quantity of facilities, materials, and administrative supervision given to white pupils. In numerous ways, West Virginia schools were never "separate but equal.",67

However, when the West Virginia Supreme Court declared that “discrimination against the colored people, because of color alone, as to privileges, immunities, and equal legal protection, is contrary to public policy and the law of the land,” Williams vs. Board of Education became a landmark decision in the history of civil rights and equality before the law in West Virginia. ${ }^{68}$ Indeed, Paul Finkleman described the case as "as one of the few civil rights victories in a southern state's highest court before the turn of the century." ${ }^{\text {,99 }}$ Following the end of Reconstruction, attempts to end segregated schools based on Fourteenth Amendment rights were, just as Martin v. Board of Education of Morgan County, generally unsuccessful. However, cases filed between 1830 and 1903 that relied on state constitutions or legislative statutes in arguing for integrated schools were often successful, although the success rate dropped after 1880. The majority of these cases occurred in the North, in states that did not have legally mandated school segregation and where it was much safer for both the plaintiffs and their lawyers to challenge segregated schools. That does not mean that black southerners accepted segregated or failed to protest segregated schools. In the 1870s and early 1880s, Kentucky blacks challenged state legislation requiring citizens to pay taxes for schools of their own race, legislation that severely limited funds for black schools and left them substantially unequal to the white schools. Their litigation led to a repeal of the law. In addition, black leaders in Louisiana challenged, but failed

\footnotetext{
${ }^{67}$ Connie L. Rice, “The 'Separate but Equal' Schools of Monongalia County, West Virginia” Journal of Appalachian Studies, 2 (Fall 1996): 323-335.

${ }^{68}$ Williams v. Board of Education.

${ }^{69}$ Finkleman, “Not Only the Judges’ Robes Were Black,” 18.
} 
to end, the re-establishment of segregated schools in 1878. Southern resistance to segregated

schools, although limited, did occur. ${ }^{70}$ Overshadowed by the earlier United States Supreme Court decision Plessy v. Ferguson, the Williams case provided southern blacks with a rare victory ... and a small beacon of light in what historian Rayford W. Logan has described as the "nadir" of African-American history. ${ }^{71}$

In an attempt to halt the growing discrimination and violence against African Americans, Clifford attended a meeting of the National Afro-American Council held at the Metropolitan Baptist Church in Washington, D.C. on December 29, 1898. Formed for "the purpose of ameliorating the condition of the colored people of the country,” the Council sent a group of prominent African Americans to visit with President William McKinley in the ante-room of the

70 Donald Nieman, "The Language of Lilberation: African Americans and Equalitarian Constitutionalism, 18301950." Black Southerners and the Law, 1865-1900 (African-American Life in the Post Emancipation South, Vol. 12) (New York: Garland Press, 1994), 262-263. The first known challenge to segregated schools occurred in Boston, Massachusetts in 1849 (Roberts v. The City of Boston). In a community action similar to Brown v. Board of Education, parents, led by Benjamin Roberts, wanted their children to be able to attend any schools in Boston. Paying taxes to support white schools that their children could not attend, they petitioned the court unsuccessfully for three consecutive years before going to court in 1849. The plaintiffs lost the case when the court ruled "special provisions" had been made for a "colored” school. Between 1881 and 1949, eleven cases went before the Kansas Supreme Court challenging segregated schools. Among the early cases (Tinnon v. Board of Education of Ottawa, 1876; Knox v. Board of Education of Independence, 1891; Reynolds v. Board of Education of Topeka, 1903; Richardson v. Board of Education of Kansas City, 1906; Cartwright v. Board of Education of Coffeyville, 1906; Rowles v. Board of Education of Wichita, 1907; and Williams v. Board of Education of Parsons, 1908), five of the seven plaintiffs won their cases. The court ruled against the plaintiffs in Reynolds $v$. Board of Education of Topeka and Richardson v. Board of Education of Kansas City. In the Reynolds case, the court ruled that the Fourteenth Amendment to the U.S. Constitution did not supersede Kansas Law and in the Richardson case, the court upheld the constitutionality of special legislation in Kansas. Neither Massachusetts nor Kansas had laws segregating blacks and whites in schools in their Constitutions, nor did they adopt segregation laws immediately after the Civil War. Indeed, the majority of the cases challenging segregated schools occurred outside the south. In addition to Williams v. Board of Education of Fairfax District, which resulted in a victory for Clifford 1898, two years after the landmark case Plessy v. Ferguson, there was also a challenge to Georgia's segregated school system in 1899. In a case remarkably similar to the Williams case, in Cummings v. Board of Education of Richmond County, Georgia, the plaintiff challenged a local school board's decision to close a black school for monetary purposes while it continued to operate two white schools. The Georgia Supreme Court, as well as the United States Supreme Court, upheld the school board's decision, claiming there was no evidence that the board based its decision on racial discrimination and that school officials had the authority to allocate school funds at their discretion. See J. Morgan Kousser, "Separate but Not Equal: The Supreme Court's First Decision on Racial Discrimination in Schools” in Nieman's Black Southerners and the Law (1994), 189-216.

${ }^{71}$ Rayford W.Logan, The Betrayal of the Negro from Rutherford B. Hayes to Woodrow Wilson (New York: DeCapo Press, 1997), 52-53. 
White House on December 31, 1898. Those who met with McKinley included Bishop Alexander Walters; Bishop B.W. Arnett; Judson W. Lyons (Register of the Treasury); H.P. Cheatham (Recorder of Deeds); George H. White (Congressman from North Carolina); J.W. Thompson, New York; John Mitchell, Jr., Virginia; Rev. W.L. Taylor, Virginia.; John C. Dancey, North Carolina; Cyrus F. Adams, Illinois; William A. Pledger, Georgia; and J.R. Clifford. ${ }^{72}$ Clifford later wrote that McKinley’s policy on the lynching question would bring “good results” if it were carried out, but added "the flavor is sweet but we hope it is not sugar-coated pills to catch Negro votes."73 In the future, Clifford would move further in national politics and organizations, joining with like-minded men in the hope of achieving his goals.

As the decade of the 1890s came to a close, Clifford delivered one of his most eloquent speeches before the Afro-American Council at a meeting held in August of 1899 in Chicago, Illinois. In an appropriate and prophetic presentation titled “The Races-Mutual Relations,” Clifford argued that America would never achieve its promise of a free and democratic society until it provided men and women of all races with the rights and privileges guaranteed to them under the United States Constitution. ${ }^{74}$ Generations later, men and women of vision would still be pursuing the same goal.

\footnotetext{
${ }^{72}$ Richmond Planet, January 7, 1899.

73 “Fears Sugar Coated Pills,” Pioneer Press printed in the Richmond Planet, December 16, 1899.

${ }^{74}$ Paul I. Clifford, “Certain Dimensions of the Life and Times of J.R. Clifford,” 30.
} 


\section{CHAPTER FOUR}

\section{"A MANLY BODY OF MEN:”}

\section{National Alliance and Individual Disagreement}

"Our rights are ours to enjoy only by fearless agitation and contention, and the party or parties who are too cowardly to do both, are undeserving of their rights.",75

J.R. Clifford made his first entrance into national black political circles in 1882 when he attended the Knights of Wise Men, a black fraternal organization, convention held in Atlanta, Georgia, and delivered a speech to such well know African Americans as F.L. Cardoza, Bishop Henry McNeal Turner, Richard Gleaves, Rev. William J. Simmons, R.P. Brooks, and "some of the other most gifted men of the country." Simmons reported that, at the time, "Mr. Clifford was but little known” to most of the men who were traveling to Atlanta. Robert Peel Brooks, an eloquent orator and lawyer from Virginia, spying the unfamiliar thirty-four year old Clifford on the train from Nashville, Tennessee to Atlanta, immediately asked John Cromwell who the young man was. Crowell replied, “The orator.” Brooks laughed heartily at the notion saying "it would be hard oration" and one in which "he wanted to be absent" from when it occurred. Much to his surprise, Clifford's speech electrified his audience, and it was Brooks who led the movement to present Clifford with a gold-headed cane for his endeavor. ${ }^{76}$

In March 1897, Alexander Crummell, along with John W. Cromwell, W.E.B. DuBois, Kelly Miller, and other black intellectuals organized the American Negro Academy, a group of forty leaders in the black community whose purpose was to encourage African American scholarship, culture, and intellect, but who also wanted the "opportunity to teach blacks, directly

\footnotetext{
${ }^{75}$ Pioneer Press, December 5, 1914.

${ }^{76}$ William J. Simmons, “ J.R. Clifford, Esq.: Editor, Lawyer, Teacher, Orator,” Men of Mark: Eminent, Progressive and Rising (Cleveland, Ohio: Geo. M. Rewell \& Co., 1887), 274-277. Available on-line at:

http://docsouth.unc.edu/neh/simmons/simmons.html.
} 
or indirectly, who their political friends and enemies were" and "the importance of race pride."77 The majority of the men in the Academy were Republicans, yet they did not support the party enthusiastically. Although most believed that the Republican Party's failed to offer any significant commitments to blacks while assuming their allegiance, they felt there was no political alternative. Clifford became an early member of this prestigious group. The American Negro Academy produced a series of twenty-two "Occasional Papers" that fiercely refuted the ideas and concepts of race critics. Although Clifford did not produce an occasional paper, he was to play a prominent role in the leadership of the American Negro Academy. ${ }^{78}$

Clifford also became a member of the National Afro-American Council, the revitalized version of Afro-American League of America that emerged following a meeting of black leaders in Rochester, New York in September of 1898. At the Rochester meeting, T. Thomas Fortune, who supported inter-racial marriages and mixed schools, opposed the membership of ex-Minister John H. Smyth who was adamant in his opposition to both. Clifford reported in the Richmond Planet that “A good many exchanges and a lot of people who don't know what they are fussing about seemed to be miffed at Hon. T. Thomas Fortune for promptly sitting on Mr. Smyth and his backwoods ideas last month at the Rochester New York Council. We don't do anything of the kind, as we think President Fortune acted very wisely in ruling as he did. Such speeches as Smyth attempted to make before the Council are the kind that should be laid upon the shelf and never resurrected. There should be intermarriage and [no] separate school laws in every state in the union, and if so, there would be no race troubles in America. Intermarriage will cause a stoppage in the influx of half-breed children in the United States and mixed schools will cause

\footnotetext{
${ }^{77}$ Alfred A. Moss, The American Negro Academy: Voice of the Talented Tenth (Baton Rouge, La.: Louisiana State University Press, 1981), 264-266.

${ }^{78}$ Moss, The American Negro Academy, 264-266; Although Clifford did not write any of the Occasional Papers, he was an influential and active member of the Academy until its demise in 1928. See Appendix IV for a list of national
} 
white and black children to grow up in friendship, and we say again that Thomas Fortune added laurels to his brow when he silenced John H. Smyth of Virginia in his speech at the Rochester Council.,79

Following the September meeting, Clifford attended the National Afro-American Council meeting held at the Metropolitan Baptist Church in Washington, D.C. on December 29, 1898, and was one of the members who visited with President William McKinley in the ante-room of the White House two days later on December 31. Delegates to the Washington meeting chose Bishop Alexander Walters to serve as president of the organization. By 1899, Booker T. Washington and those who supported his ideas played a dominant role in the Council. When the Afro-American Council held its meeting the following year in Chicago, Illinois, those who advocated a militant approach in race relations attacked Washington for his accommodationist views. Clifford attended the meeting and delivered an address titled "The Races—Mutual Relations." ${ }^{80}$ While there he also attended a meeting of Afro-American Editorial Association. Clifford reported that the “old editorial association” was gasping for life and only three old members there, John R. Clifford, John E. Bruce and Cyrus F. Adams. With just those three present, Clifford and Bruce nominated Adams for President, Bruce nominated Clifford for Secretary, and Clifford nominated Bruce for Treasurer, leading Bruce to fall off of his chair laughing. ${ }^{81}$

associates including Academy members.

79 “Thinks Mr. Fortune Acted Wisely,” Richmond Planet, October 15, 1898. The Afro-American League of the United States, formed under the leadership of T. Thomas Fortune in January of 1890, started with over 100 African Americans from across the country who pledged to fight segregation and discrimination. By 1893, the League failed due to lack of support. The Afro-American Council emerged in 1898 and lasted until 1908. For a list of officers from each state see Cyrus Field Adams, "Officers of the National Afro-American Council," The National AfroAmerican Council, Organized 1898: A History of the Organization ,Its Objectives, Synopses of Proceedings, Constitution and By-Lays, Plan of Organization, Annual Topics, etc. Daniel A.P. Murray Collection, 1818-1907, Library of Congress.

${ }^{80}$ David Levering Lewis, W.E.B. Du Bois: Biography of a Race, 1868-1919 (New York: Henry Holt and Company, 1993), 230.

${ }^{81}$ Pioneer Press, October 3, 1914,. The next year, Adams as President met and joined Booker T. Washington’s Business League, where he remained as President of the Editorial Association under the leadership of the Business 
In addition to his participation in national organizations such as the American Negro Academy, The National Afro-American Council, and the Afro-American Press Association, Clifford remained active in West Virginia politics. When A.B. White ran for Governor of West Virginia in 1900, a black Republican and Booker T. Washington cohort, Phil Waters, reported to A.B. White that several well-known black Masons, particularly Dr. Henry F. Gamble of Charleston, West Virginia, were unhappy because White failed to publish an account of their Masonic meeting in his Parkersburg newspaper, The State Journal, in 1895. Yet Waters attributed White's decline among the black constituency to Clifford, stating, "It is my opinion that the notorious Clifford is behind it, I have been following his editorials very closely here of late and am of the opinion that he would resort to anything dirty and damnable to injure the good name of any Republican." ${ }^{82}$ Less than a week later, Waters targeted Clifford again in a letter to A.B. White when he compared Dr. Gamble to Clifford claiming, "He is like Clifford somewhat, always trying to stir up strife and race prejudice.”33 Apparently Waters felt that any effort Clifford made to obtain civil or political rights stirred up "strife and race prejudice." Clearly, by 1900 the lines were already being drawn among black West Virginians; between those who argued for full citizenship rights and those who followed Booker T. Washington and his policy of “accommodation.” Yet despite the efforts of a few southern West Virginia black leaders to alienate Clifford from the white Republican leadership, Clifford developed a good relationship with many of the Republican governors of West Virginia including A.B. White.

It is unclear who took the initiative, but Clifford and White began to exchange letters sometime between February of 1900 and September of 1901. In a letter written to A.B. White,

League for ten years followed by a position in Washington, D.C. The Afro-American Press Association began in 1880.

${ }^{82}$ Letter from Phil Waters to A.B. White, February 13, 1900, A.B. White Papers, West Virginia and Regional History Collection (hereafter WVRHC), West Virginia University. 
Clifford wrote, "I am sincerely interested in you, as you have been in me," and referred to White's "past kindnesses” to him. Although it is not clear what kindnesses Clifford was referring to, he had been corresponding with White about the "nefarious 'Jim Crow’ practice” of segregating of black passengers on the Norfolk \& Western Railroad in the eastern panhandle, despite the absence of Jim Crow laws in West Virginia. Clifford reported to White that the Norfolk \& Western had been forcing black passengers into segregated cars every since the law went into effect in Virginia. Clifford decided White should let him handle the matter and that he could "kill it." Claiming that White had enough to contend with as governor and that he hoped to see White as the next United States Senator from West Virginia, Clifford added, "I doubt if your interference would help your future prospects, in consequence of which, I am willing to abide time and strive to defeat it." 84

Clifford, along with other "radicals" calling for full manhood rights, continued to attend meetings of the National Afro-American Council despite the growing influence of Booker T. Washington in the organization. The National Afro-American Council, along with the AfroAmerican Press Association met again in Indianapolis, Indiana, in August of 1900. At the meeting Bishop Walters, President of the Council, urged the race to "act independently in politics, and declared that politicians must cease to make the Negro a pawn in the political game.” Delegates attending the Afro-American Press Association again elected Cyrus Field Adams as president. However, this time, the group elected George Knox as Vice-President, W.H. Steward as Treasurer, and Alex Manly as Secretary. ${ }^{85}$ When the Association held its annual meeting at the Bethel A.M.E. Church in Philadelphia, Pennsylvania in August of the following year, Clifford presented a paper titled "The Power of the Press." Among the discussants were H.T. Bowman of

${ }^{83}$ Phil Waters to A.B. White, February 19, 1900, A.B. White Papers, WVRHC. 
the Advance Citizen in St. Louis, Illinois, J.L. Thompson from the Des Moines, Iowa Bystander, and M.M. Lewey from The Sentinel in Pensacola, Florida. ${ }^{86}$

Throughout 1901 and 1902, Washington secretly moved closer to the controlling the AfroAmerican Council through financial contributions to the Council's legal bureau. West Virginia sent three representatives. Despite rumors that the radicals would attempt to gain control of Council from the dominant Bookerite forces, Washington and his followers faced little opposition at the National Afro-American Council meeting held in St. Paul, Minnesota in 1902.

Washington's supporters were successful in electing T. Thomas Fortune as President and, despite a discordant tone and uneasy atmosphere, took control of the Council. Soon after the meeting, Trotter charged the Council with betraying African Americans and abandoning the organization's original purpose: protecting black political interests. Clifford attended the 1902 meeting along with fellow West Virginians George E. Curry and Miss Otelia Kent. ${ }^{87}$

As the only viable organization for national protest, members expected another confrontation between Washington's followers and the radicals at the next annual meeting to be held in Louisville, Kentucky in July of 1903. The radicals, including Clifford, did try to wrestle control of the Council away from Booker T. Washington in Louisville. At the meeting, Boston radicals William Monroe Trotter, George W. Forbes, and William H. Ferris successfully solicited a resolution urging President Theodore Roosevelt to reduce southern representation for passing state legislation that led to the disfranchisement of black Americans. However, Washington's

\footnotetext{
${ }^{84}$ J.R. Clifford to A.B. White, September 3, 1901, A.B. White Papers, WVRHC.

85 “Afro American Council," Richmond Planet, September 1, 1900.

86 "The Annual Meeting of the National Afro-American Press Association, Bethel A.M.E. Church, Philadelphia, Tuesday, August Sixth, Nineteen One,” Daniel A.P. Murray Collection, Library of Congress.

${ }^{87}$ For a list of officers from each state see Cyrus Field Adams, "Officers of the National Afro-American Council," The National Afro-American Council, Organized 1898: A History of the Organization ,Its Objectives, Synopses of Proceedings, Constitution and By-Lays, Plan of Organization, Annual Topics, etc. (1902) Daniel A.P. Murray Collection, 1818-1907, Library of Congress. Stephen R. Fox, The Guardian of Boston: William Monroe Trotter
} 
men, in an imposing display of power, rejected all other proposals the radicals made to the Council. $^{88}$ As a strong proponent of reducing Southern representation in Congress as retribution for civil rights violations, Clifford later wrote an editorial on the subject in the Pioneer Press that William Monroe Trotter reprinted in the Boston Guardian. Trotter commended "the mathematical reasoning from a southern Colored newspaper, from down there where any dangers are real.” In an article titled “Cut Them Off,” Clifford wrote:

It is claimed by some who see one way and through only one keyhole that to cut off southern congressional representation would be doing evil for it. We don't see it that way. For more than a hundred years, all whites who in violation of the United States Constitution overcame and worked the blacks - by calling them theirs and property, voted for three Negroes out of every five. So you see if a hundred Negroes were called property, the old self-styled "master" voted 61-equal to 61 voters. Yet they were advertised as beasts and property. There is a difference today, but woe be the difference, for it is thus. When the Negroes of the south were called slaves, 60 out of every 100 voted by proxy while now under freedom none vote, or if they do, they are not counted. If they had no right to vote 60 out of every hundred and crowd the halls of congress with ilk advocates to feed and foster slavery, what right have they to go 40 "better" and send more of a worse type as congressmen to congress? Cut off 40 odd and keep them off till they either die or do better. ${ }^{89}$

In addition to their concerns over the growing disfranchisement of blacks in the South, as editors, Clifford and Trotter were also alarmed at Washington’s power increasing influence over the black press. Not only did the Tuskegee men dominate the Louisville meeting of the AfroAmerican Council, they held hegemony in the Afro-American Press Association meeting held prior to the annual meeting. Numerous rumors of Washington buying shares, purchasing advertising, making contributions, and subsidizing black newspapers to exert his influence circulated among the radicals were not unfounded. From its creation in 1901, Trotter harshly

(New York: Athenaeum, 1970), 46-47; August Meier, Negro Thought in America, 1880-1915 (Ann Arbor: University of Michigan Press, 1968), 173-174.

${ }^{88}$ Fox, The Guardian of Boston, 48-49.

${ }^{89}$ Boston Guardian, January 23, 1904; Clifford is referring to Article 1 Section 2 of the Constitution of the United States of America that states the number of representatives chosen from a state to serve in the House of Representatives is decided based on population, including those "bound to Service for a Term of Years" (slaves) who 
criticized Booker T. Washington in the pages of the Boston Guardian. Trotter accused Washington of subsidizing three black rival newspapers in Boston, the Advocate (1902), the Enterprise (1903), and the Colored Citizen (1903), in an attempt to financially ruin the Guardian. Washington also secretly contributed to the E.E. Cooper's Washington, D.C. Colored American, Alexander’s Magazine, Boston's Colored American Magazine, the New York Age, and possibly, Chase's Washington, D.C. Bee. Booker T. Washington made numerous attempts to purchase the New York Age in 1903 and 1904, but was unsuccessful..$^{90}$ In February of 1904, Clifford’s long time friend and associate John W. Cromwell resigned as editor of the Washington, D.C. Record after learning Booker T. Washington exerted control of the newspaper through one of its owners, Alex Manly. Cromwell, a race advocate who frequently criticized Washington, published information on a secret meeting in the Record. Washington then pressured Manly to control Cromwell, thereby revealing his involvement in the paper. ${ }^{91}$ In fact, Booker T. Washington and his “Tuskegee Machine” spent well over \$3,000.00 in 1904 in “hush money” to support certain members of the black press. ${ }^{92}$ Washington's attempts to influence the black press merely served to bring additional coalescence to the growing anti-Washington movement.

In the fall of 1904, Clifford was busy making preparations for a convention of the Lincoln National League to be held in Charles Town, West Virginia, on the tenth of October as well as doing campaign work for the fall election. Phil Waters, Washington's ally, served on the Lincoln League committee with Clifford and there is no record of whether the two were amiable or not. However, Clifford was having problems with the State Republican Committee and in a letter to

would count as three fifths of a person.

${ }^{90}$ David Levering Lewis, W.E.B. Du Bois: The Biography of a Race, 1868-1919 (New York: Henry Holt \& Co., 1993),, 301-302; Fox, 70-71; August Meier, "Booker T. Washington and the Negro Press: With Special Reference to the Colored American Magazine,” Journal of Negro History, Vol. 38, No. 1 (Jan., 1953), 67-76.

${ }^{91}$ Boston Guardian, March 12, 1904.

${ }^{92}$ Fox, The Guardian of Boston, 87. 
Governor A.B. White questioned the "spirit of the leaders." White replied that he took "it for granted that they are honorable men and have no desire to mistreat you or any other person” and suggested that "Mr. Noel is the one who is at fault" rather than the party. John Noel of Fayette County, the first head of the Negro Bureau of the Republican Party in West Virginia, played an active role in William O. Dawson's campaign for Governor of the state in 1904 and, like Phil Waters, was a supporter of Booker T. Washington and the Republican’s economic agenda. Apparently, in an effort to enlighten the party on the concerns of black West Virginians, particularly those who expected more from the Republican Party, Clifford felt that his paper should be circulated among the state Republican committees. White promised "to appeal to the State Committee" for Clifford's "utmost consideration," but claimed he had "nothing to do with the party's State management;" a clear indication that there would be no changes made. ${ }^{93}$ Problems with state and local Republican leaders were nothing new; Clifford had endured them for over three decades. By 1904, however, the divisions among black West Virginians which emerged with the industrialization of southern West Virginia and broadened when Republicans took control of the state under the leadership of industrialist Stephen B. Elkins in 1896, deepened amid the Washington/anti-Washington controversy. Yet in the spring of 1905, those difficulties were insignificant when compared to the fight Clifford was about to engage in, a battle wrought with numerous consequences for himself and imperative for the life of his son.

On Thursday evening, April 6, 1905, J.R. Clifford and his son Paul participated in a shooting that resulted in the death of Jacob Turner, Jr. and the wounding of brothers Joseph and Charles Cook. The shooting took place near the Cumberland Valley Railroad tracks west of Clifford's house on West Martin Street, a portion of the city the press referred to as "Africa."

93 Washington Post, September 26, 1904; Letter from A.B. White to J.R. Clifford, October 24, 1904, A.B. White 
Although the shooting stemmed from class conflict within the black community, Clifford's enemies were quick to take advantage of a situation that could lead to Clifford's imprisonment and the financial ruin of the Pioneer Press. ${ }^{94}$

Late in the afternoon, John Clifford, Jr., age eleven, was playing with a neighborhood friend, Raymond Turner, the son of Jacob Turner. A dispute among the two children resulted in name calling and a fight. Jennie Cook, Jacob Turner’s niece, heard someone yelling "Black nigger” and went outside where she witnessed Paul Clifford, John's older brother, in the process of separating the boys. Paul must have been near by and, just as Mrs. Cook did, heard the boys fighting. Mrs. Cook immediately pulled Raymond away from Paul Clifford telling him "Let go of this boy.” A verbal altercation then occurred between Paul and Jennie Cook, who claimed that just as she got to her doorstep, she heard Paul call her "a damn old whore ... a broken down whore.” Mrs. Cook then threatened Paul, telling him that she would tell her husband and he would "shoot him like a dog." Soon after, Jenny Cook, along with Jacob Turner, called on Paul at his home and asked for an explanation of his conduct toward Turner's son, Raymond. At the end of the meeting, Mrs. Cook repeated her warning to Paul again in the presence of Dr. Samuel Gray, who lived adjacent to the Clifford house, and Paul's sister. This time, she stated, "You wait till Joe catches you; he’ll fix you. He’ll kill you, you dirty nigger."95

When Joseph Cook, Jennie's husband, arrived home, Jennie told him about the incident and he left the house and went to the hotel in Martinsburg where his brother Charlie worked to inform him of the incident. Charlie lived with Joseph and Jennie Cook, and when he returned

\footnotetext{
Papers, WVRHC.

94 "Fatal Shooting," Martinsburg Statesman, April 14, 1905. All of those who participated or were present during the shooting were African American. Dr. Gray, a thirty-three year old physician from Maryland moved to Martinsburg approximately three years prior to the event. Joseph Green, a teamster, and his wife Rouie lived nearby on West Burke Street. Will Brown was thirty-three years old and lived on West Martin Street with his wife Annie and his son, Howard. The Cooks were related to Jacob Turner as well as John Basey, one of the witnesses in the case.
} 
home that evening, he found Joseph and Jacob Turner waiting for him at the front door. A little before eight o'clock that night, Paul Clifford left his home and walked west on Martin Street to go outside the city limits to Tiny Smith's house for a pitcher of milk. J.R. Clifford, who did not "allow Paul to carry a gun," knew of the threats against Paul and advised him to carry a pistol when he left home that night. ${ }^{96}$

After Paul left the house, Jacob Turner, along with Joseph and Charles Cook, who said they were on their way to their sister-in-law's, walked west on Martin Street. Turner went to a nearby house, but the Cooks continued up the street and met Paul as he returned home at the point where the Cumberland Valley railroad tracks crossed West Martin Street. Joseph Cook told Paul that he was just the "one he wanted to see" and asked Paul what kind of name he called his wife. Paul replied that he "didn’t call her any name at all," and attempted to avoid a confrontation. According to Charlie Cook's testimony, Joseph Cook told Paul "You bulldoze everybody up here on the hill here, but you can’t bulldoze us." Soon after, Jennie Cook joined the three men in the street and insisted to her husband and brother-in-law that Paul had called her a vile name. All three Cooks maintained that Paul then called Mrs. Cook “a God damn liar,” a comment that led Charlie Cook to strike Paul with his fist. When he struck Paul, Paul was holding the pitcher of milk in his left hand and his right hand was in a pocket of his pantaloons, grasping the revolver. The brothers continued their assault and during the encounter, Charlie Cook noticed that Paul Clifford had a revolver in his coat pocket. Claimed that Paul was trying to pull it from his pocket, both Cooks wrestled with Paul for control of the gun and the gun went off, striking Charlie Cook in the finger. In the ensuing struggle, the gun went off a second time, shooting Joseph Cook in

\footnotetext{
${ }^{95} 52$ S.E. 981, 59 W.Va. 1, State v. Clifford (W.Va. 1906), 7.

${ }^{96}$ State v. Clifford.
} 
the thigh. ${ }^{97}$

According to another neighbor, William Brown, Paul called out to him during the struggle for help and that "under the obligations, I had to go to his call.” Paul Clifford and Will Brown were both members of the Odd Fellows and, therefore, obligated to help each other under a code of brotherhood. The Cooks, however, were yelling “Get the gun!” and according to Brown, he tried to reach for it. Other witnesses said Brown went up the street to get Paul's father, J.R. All witnesses agreed that at that point, J.R. Clifford came out of his office and ran down the street carrying a Winchester repeating shotgun and calling for Paul. Will Brown claimed, "When I saw the old man with a gun, I started back.” Rouie Green, wife of Joseph Green, testified that J.R. Clifford came out of his house and across the street carrying a rifle. She stated, "He come in the middle of the street. He was running" and "I heard the snap. You know how steel snaps when it comes together? It was like that. I could see the steel and see him lift it up and fire. The crowd all ran when he shot.” When asked if she saw Jacob Turner, Green said no because "they all scattered when J.R. Clifford came, and they didn’t come back until after the Cliffords left.”98

Some of the witnesses reported that after Paul answered his father, J.R. Clifford called out, "Let him go" and threatened to fire if they did not; others claimed J.R. yelled, "Look out, and I'll kill some of the sons of bitches.” J.R. reported that there were three men beating Paul when he arrived, but it was too dark to recognize any of them. Other witnesses reported that Jacob Turner was one of the men involved in the attack. Reports varied on the series of events and the number of shots fired. According to witnesses, between three and six shots were fired. Those who reported hearing six shots maintained that Paul and J.R. both fired three times, others claimed that

\footnotetext{
${ }^{97}$ State v. Clifford; Testimony taken at the inquest into the death of Jacob Turner, 7 April 1905, State v. Paul Clifford, Berkeley County Circuit Clerk’s Office (hereafter BCCCO), Berkeley County Courthouse, Martinsburg, West Virginia.

98 State v. Clifford.
} 
J.R. did not fire at all. Joe Green, who heard four shots, insisted the first two came from Paul's gun and the second two from J.R. Clifford's rifle. Green maintained that Clifford fired his first shot approximately five feet prior to reaching the railroad track and the second shot when he was about ten feet from Jacob Turner. Paul stated that his gun fired a third shot although he tried to put his finger behind the trigger to keep if from being firing, but he didn’t know if it occurred when Charles Cook threw him to the ground or when he was trying to get up. J.R. Clifford said it fired as Paul "arose from the backward position in which he had been thrown by Cook." Charles Cook admitted that he threw "him from me as far as I could," heard shots, and ran under a fence towards the place where Jacob Turner was standing. Amid the gunfire, a bullet struck Jacob Turner in the head, killing him instantly. ${ }^{99}$

When officers arrived at the scene, they sent for the coroner and summoned a jury on the spot to view the body. The court issued warrants for the arrest of both J.R. and Paul Clifford. The following morning, witnesses appeared to testify at an inquest. Among those called to testify were John Basey, Joseph and Rouie Green, William Briscoe, William Brown, J.T. Carter, and the Cooks, Jennie, Joseph, and Charles. Fulton Carter, Robert Carter, and Fred Hogan were also at the scene, but were not called to the witness stand. The witnesses presented conflicting testimony, not only on the number of shots fired, but who fired the final shot that killed Jacob Turner. Most of those who testified attributed Turner’s death to Paul. However, Jennie Cook adamantly insisted that it was J.R. Clifford who fired the final shot, fatally wounding Turner. At the end of the testimony, jurors, Stephen R. Snodgrass, Charles H. Wolfe, W.L. Strader, Harvey A. Bush, M.W. Riordon and Percy DeGrange, were unable to determine which Clifford fired the

${ }^{99}$ State v. Clifford. 
fatal shot. $^{100}$

On April 18, 1905, a Berkeley County grand jury indicted both J.R. and Paul Clifford on numerous counts of felonies in the shooting. Included in the indictment were four felony indictments against Paul: assault with intent to kill; murder, in the shooting of Jacob Turner; shooting Joseph Cook with intent to kill; and shooting Charles Cook with intent to kill; and one misdemeanor, carrying a concealed weapon. The court also charged J.R. with four felonies: assault with intent to kill; murder, in the shooting of Jacob Turner; shooting with intent to kill Joseph Cook; and shooting with intent to kill Charles Cook. ${ }^{101}$ When J.R. and Paul appeared in the courtroom a few days later for their arraignment, father and son were hand-cuffed together. Both men entered pleas of not guilty. The parents of Jacob Turner hired lawyers H.H. Emmert, W.B. Lindsay and W.W. Downey to assist Berkeley County Prosecuting Attorney A.B. Noll with the prosecution. J.R. Clifford and his son hired the law firm of Walker and Woods to represent them. The court scheduled Paul's trial for May 2, 1905, and J.R.’s for May 4, 1905. Apparently, A.B. Noll believed he had an "open and shut” case. However, the Martinsburg Statesman reported the "Battle promises to be hard fought one."102

J.R. and Paul remained in jail. On April 25, 1905, J.R. came to the courtroom to demurrer the indictment. The defendants also moved to quash the indictments, but failed. Paul's trial began on a Tuesday, the second of May, and ended the following evening. Spectators filled the courtroom both days. After two days of testimony, the jury began deliberation at 4:30 on Wednesday evening, adjourned for supper, and returned at 7:30 that night. They returned the verdict, Guilty in the Second Degree, a short time thereafter, a conviction that carried anywhere from five to eighteen years in the state penitentiary. Paul's attorney quickly requested the judge

100 State v. Clifford. 
set aside the verdict and issue a new trial. ${ }^{103}$

However, on June 27, 1905, Judge E. Boyd Faulkner heard the motion for a new trial and after reviewing the case, overruled the motion to set the verdict aside. The judge noted that the accused "was not without excuse for his act," but that he acted wrongly and had to pay for those actions. Faulkner then sentenced Paul Clifford to ten years at the state penitentiary at Moundsville, West Virginia. Paul and his lawyers made a motion to appeal the case to the West Virginia Supreme Court on the basis of trial errors and the court agreed. The court gave Paul thirty days to appeal the decision and placed the prisoner under the sheriff's custody until the warden could transport him to Moundsville. Paul was twenty-three years old. ${ }^{104}$ The state decided not to prosecute J.R. Clifford on Felony 1 for his involvement in the shooting and he remained out of jail on bail.

During Paul’s trial, W.E.B. Du Bois, a professor from Atlanta University in Atlanta, Georgia, Frederick McGhee, a black Democrat and Minnesota’s first African-American attorney from St. Paul, Minnesota, and Charles E. Bentley, a prominent African American physician from Chicago, Illinois, disgusted with the politics of the Afro-American Council under the domination of Booker T. Washington, decided to hold a meeting of "like-minded men" who did not share Washington's political philosophy. ${ }^{105}$ According to Du Bois biographer David Levering Lewis, Du Bois then issued a call to over fifty men that he described as "educated, determined, and unpurchasable,” men who "had not bowed the knee to Baal."106 The men who answered the call were part of the "Talented Tenth,” a cadre of college-education African Americans, lawyers,

\footnotetext{
101 “Circuit Court,” Martinsburg Statesman, April 21, 1905.

102 “Clifford Trial,” Martinsburg Statesman, April 21, 1905.

103 “Murder: In the Second Degree,” Martinsburg Statesman, May 5, 1905.

104 “Ten Years,” Martinsburg Statesman, June 30, 1905.

${ }^{105}$ Lewis, W.E.B. Du Bois, 315-322.
} 
educators, doctors, ministers, and editors who could assist the race, not only in education, but in the attainment of civil and political rights. J.R. Clifford was among the fifty-nine men who signed the call to attend the meeting scheduled for July in Buffalo, New York. However, Paul's conviction and his own indictment precluded his attendance at the 1905 meeting. Twenty-nine others did attend the historic meeting, although racial prejudice forced the group to stay in Fort Erie on the Canadian side of Niagara Falls. Considered "a new epoch in the history of NegroAmerica," this group’s purpose was to "foster high ideals” and “conduct aggressive, manly agitation for every right for the Negro that is now given the white man." ${ }^{107}$ Between September and December of 1905, membership in the Niagara Movement grew from fifty-four men in eighteen states to 150 members in thirty states. ${ }^{108}$

As the first meeting of the Niagara Movement came to a close, on July 15, 1905, J.R. and Paul Clifford filed eight Bills of Exception with the West Virginia State Supreme Court in an attempt to overthrow Paul's murder conviction. Paul's case came before the Supreme Court in February 1906. The court found six assignments of error in the case. The first related to “instructions given at the instance of the state.” The court's refusal to allow J.R. Clifford to answer pertinent questions concerning his knowledge of previous threats made against his son and Paul's purpose for being in possession of a weapon that night provided the basis for errors two, three, four, and five. The final error was due to the lower court's refusal to set aside the verdict and order a new trial. Therefore, the West Virginia Supreme Court of Appeals ruled that the circuit court erred in its verdict, reversed the decision, and ordered a new trial. ${ }^{109}$

On April 24, 1906, the circuit court again indicted Paul Clifford for the murder of Jacob

\footnotetext{
${ }^{106}$ Lewis, W.E.B. Du Bois, 315-322.

107 "The Significance of the Niagara Movement, Voice of the Negro, Vol. 2, No. 9 (September 1905): 600-602.

108 "The Niagara Movement," Voice of the Negro, Vol. 2, No. 9 (September 1905), 619; "The Growth of the Niagara Movement," Voice of the Negro, (January 1906): 43-45.
} 
Turner. This time, the jury found Paul "not guilty." Two days later, the court dismissed the charges of felonies one through five against Paul Clifford and felonies two through five against J.R. Clifford. The ordeal was finally over. ${ }^{110}$

The timing could not have been better. Clifford, West Virginia Secretary of the Niagara Movement and, therefore, a member of the Executive Committee, was on the 1906 Committee of Arrangements along with F.H.M. Murray of Alexandria, Virginia, L.M. Hershaw of Washington, D.C., and W.E.B. Du Bois. The second Niagara Movement meeting, in commemoration of the $100^{\text {th }}$ birthday of John Brown, was to be held at Clifford's alma mater, Storer College at Harpers Ferry. The organizers scheduled most of the meetings in the Anthony Hall auditorium where Fredrick Douglass delivered his famous speech in praise of John Brown on May 30, 1881. Clifford was instrumental in securing accommodations for Niagara members at special rate of $\$ 1$ per person, per day for room and board. In addition, the guests would have access to all of the college's facilities including tennis courts and croquet lawn.

On August 15, 1906, approximately 150 of the most progressive black men and women in America came to Harpers Ferry to attend the opening sessions of the second Niagara Movement meeting. Following registration, the men attended committee meetings in the afternoon. That evening, F.H.M. Murray called the meeting to order, Miss Eva Herrod performed a solo, and President H.T. McDonald of Storer College welcomed the members to the college. Following the welcome, J.R. Clifford delivered the keynote address. In what William Monroe Trotter called a "stirring speech," Clifford welcomed the members to West Virginia, discussed the fruits of John Brown's labor, and related an incident that occurred when Fredrick Douglass came to deliver his address on John Brown at Harper’s Ferry and Andrew Hunter, John Brown’s prosecutor, came up

${ }^{109}$ State v. Paul Clifford. 
at end of speech and grasped Douglass's hand although he originally tried to stop the address. Clifford maintained that John Brown deliberately tried to anger the South into starting the war, knowing the South would "get whipped," and that the object of the Niagara Movement was to make the Colored people finally realize they were free. ${ }^{111}$ Du Bois delivered the concluding statement of the evening.

On Thursday evening, following the morning and afternoon sessions, William Monroe Trotter, Max Barber, Fred L. McGhee, W.H.H. Hart, and Rev. Charles Morris delivered speeches. In addition, J.R. Clifford’s 16 year old daughter, Mary, recited “The Credo.” Early Friday morning, the group participated in a silent, barefoot pilgrimage to Old John Brown's Fort, located one mile from Harper’s Ferry.

Afterward, Du Bois wrote, “There are some people who doubt the wisdom of such fearless agitation at this time.” However, it was John Mitchell, Jr., editor of the Richmond Planet, who captured the difficulties facing the men and women who formed the Niagara Movement:

Their language is radical and conservative all in the same breath, so to speak. There is hardly a colored person in all this land who has a spark of racial manhood, but what will be affected by the boldness of the appeal. It rings true and we would be false to every trust and a traitor to every racial instinct were we to deny that the utterances and deliverances had touched us deeply. Still these members of this movement, the leaders in this cause have taken a step which will be supported by the boldest members of the race everywhere. But in the Southland such an address would be tabooed by the conservative Negroes from one part of that section to the other.

Followed by:

The men who drafted it will be considered to be a set of dissatisfied cranks who are seeking ideals impossible of realization. Still every great revolution and every powerful reform movement have been championed by "cranks" of this kind and the conservative elements have afterwards come in and enjoyed the benefits while the agitator had to depend for his salary upon the promises of the Father and payments realized after passing

\footnotetext{
${ }^{110}$ State v. Paul Clifford.

111 “Great Niagara Meeting Opens,” Boston Guardian, August 25, 1906.
} 
through the door of a casket and emerging on the other side as a spirit in the land beyond. $^{112}$

On the Monday prior to the opening of the second Niagara meeting, August 13, an incident took place in Brownsville, Texas that would have repercussions for President Theodore Roosevelt and affect African Americans across the nation. Authorities accused the men of the First Battalion of the $25^{\text {th }}$ Infantry Regiment (Colored), one of only four congressionally authorized African-American military units and a source of pride among black Americans for their military bravery against the Sioux and during the Spanish-American War in both Cuba and the Philippines, of climbing over the walls at Fort Brown and shooting up the nearby town of Brownsville, although none of the men were identified. Earlier, Brownsville residents who did not want the regiment stationed at Fort Brown requested that the troops not be sent there. However, Secretary of War William H. Taft rejected the request. Upon arrival, the troops faced discrimination, segregation, and increasing hostility in the town that eventually erupted into violence. As a result, African Americans across the country, including those who attended the Niagara meeting, anxiously awaited the outcome. ${ }^{113}$

Tension turned to fear and outrage only a month later when a race riot broke out in Atlanta, Georgia on September 22, 1906, over allegations of black men harassing white women, but actually based on class conflict between whites. Atlanta, home to several of the Niagara members including Du Bois, experienced wide-spread violence for two days, with whites attacking and killing African Americans. Historian David Levering Lewis wrote, “There was bitter justice in the fact that the Atlanta Compromise of 1895 would end in the Atlanta riot of

\footnotetext{
${ }^{112}$ Richmond Planet, August 25, 1906.

${ }^{113}$ Gerald Astor, The Right to Fight: A History of African Americans in the Military (Cambridge, Ma.: De Capo Press, 1998), 81.
} 
1906." ${ }^{114}$ As a result of the violence, support for the Niagara Movement grew and Booker T. Washington's power began to erode. President Theodore Roosevelt, who failed to condemn the racial violence in Atlanta, also lost support among African Americans. On November 6, 1906, three days after the Republicans carried the mid-term elections with the aid of their black constituents, President Roosevelt dismissed 167 men of the First Battalion of the $25^{\text {th }}$ Infantry Regiment from the United States Army, including six Medal of Honor winners. Their punishment for the Brownsville violence, backed by Taft and defended by Roosevelt, sparked widespread criticism and anger among black Americans, many of whom questioned the political allegiance of African Americans to the Republican Party. ${ }^{115}$

During the winter of 1906 and the spring of 1907, Clifford was an active and loyal member of the Niagara Movement, attending meetings, recruiting members, and advocating Niagara principles throughout West Virginia. Along with other members of the Niagara Movement, he continued to issue sharp criticism to prominent African Americans who failed to stand up for the rights of African Americans. Two weeks prior to the August 1907 meeting held at Faneuil Hall in Boston, Massachusetts, Clifford criticized the black press for its support of Kelly Miller:

The editor of this paper is at a loss to understand why the Press Bureau holds up and advocates Kelly Miller for a high place in Howard University. He may have the education but what about stability of unfaltering manhood? If we had a school, or loved one as the Press Bureau claims it does Howard, we would clamor for no man who Jim-crowed himself to get to the Jim-crow exposition and made a Jim-crow speech. ${ }^{116}$

Clifford attended the third annual meeting held in Boston, Massachusetts, despite his lack of funds. In a letter sent to Judge Matthews at the West Virginia Supreme Court of Appeals,

\footnotetext{
${ }^{114}$ Astor, The Right to Fight, 81; Lewis, W.E.B. Du Bois, 334.

${ }^{115}$ Lewis, W.E.B. Du Bois, 330-335.

116 “On to Boston,” Boston Guardian, July 27, 1907; “Jim Crowist Kelley Miller Hit Hard By Manly Editor Clifford,” Boston Guardian, August 10, 1907.
} 
Clifford wrote, 'I fully intended to see you at Charles Town, but was called to Boston during the time of your late session there.” Clifford told Matthews that he had one more payment on another account due and then he would pay the debt he owed to the court. Hoping Matthews would give him "a little more time," he assured Matthews of his "honest wish to pay my debts.” In the letter, Clifford stated, "I have been pinched financially by my political foes in the hope of destroying me and my paper, but we hope to live awhile yet and smack back their cheeks politically when the time comes."117

The Niagara meeting in Boston was a huge success with approximately 800 people in attendance. In his address, Du Bois censured Roosevelt for "swaggering roughshod over the helpless black regiment whose bravery made him famous." ${ }^{118}$ However, conflict between the William Monroe Trotter and Clement Morgan over control of the Massachusetts branch of the Niagara Movement and resulted in Du Bois’ support of Morgan, marred the conference and created a schism in the movement that contributed to its decline. ${ }^{119}$ Despite urgings from the executive committee in the winter of 1907 and 1908 for the three men to settle their differences, Trotter did not return to the Niagara Movement. ${ }^{120}$

Angry at Roosevelt, who was catering to southern whites, and Taft, who was blatantly advocating lily-white Republicanism in the South, in 1908 Du Bois urged African Americans to abandon the Republican Party in favor of the Democrats, particularly the Democratic candidate for president, William Jennings Bryan. ${ }^{121}$ Trotter was also adamant in his opposition to both Roosevelt and Taft.

\footnotetext{
${ }^{117}$ Letter from J.R. Clifford to Judge Matthews, September 28, 1907, West Virginia Supreme Court of Appeals, Charleston, West Virginia. See Appendix V. for a copy of the letter.

${ }^{118}$ Lewis, W.E.B. Du Bois, 339. The Twenty-fifth Infantry Regiment was one of the black regiments that fought the Battle of San Juan Hill with Roosevelt and his "Rough Riders” in July of 1898.

${ }^{119}$ Lewis, W.E.B. Du Bois, 340.

${ }^{120}$ Fox, The Guardian of Boston, 104-110.
} 
William Monroe Trotter, Bishop Alexander Walters, former President of the AfroAmerican Council, and Rev. William H. Scott, President of the Boston Suffrage League, called for a political suffrage conference to be held at the Zion Baptist Church in Philadelphia, Pennsylvania in early April of 1908. Trotter warned that "Race traitors, spies and stool-pigeons are not wanted nor will such as are known to be of that class be admitted,” and although the call stated the meeting was "for all race men, Trotter screened those who came to the meeting. Trotter would not accept anyone who did not share his political ideology-total opposition to President Roosevelt and his Secretary of State, William Taft. Barring those who were unwilling to abandon the Republican Party and remained loyal to the administration, Trotter held the meeting upstairs in the church while men such as Calvin Chase, a Bookerite and editor of the Washington Bee, remained in the basement. ${ }^{122}$ Upstairs, the anti-Roosevelt radicals formed a new organization, the National Negro-American Political League, and elected Rev. J. Milton Waldron as the league’s president.

Clifford, one of the several "accepted men” from the Niagara Movement who attended the meeting, later reported that upon his arrival he found the Hon. James H. Hayes and Archibald Grimke sitting in the basement of the Zion Baptist Church and men stationed at the doors leading upstairs to the auditorium. According to Clifford, the men had instructions from Trotter to keep Hayes and Grimke downstairs as long as possible. Clifford went upstairs and asked Trotter why he issued such orders and Trotter answered, "if they come, they will come over my dead body." Clifford informed Trotter they were coming upstairs “bloodshed or no bloodshed,” and returned to the basement where he found Hayes preparing to leave. Clifford convinced him to stay and soon after, Hayes and Grimke went upstairs. Although scheduled to speak at nine o'clock that

\footnotetext{
${ }^{121}$ Lewis, W.E.B. Du Bois, 341.
} 
evening, Grimke sat on the rostrum until after eleven. In the meantime, Trotter called on a dozen other men to speak and then walked off the stage rather than call Grimke to the stand. ${ }^{123}$ Trotter reported his version in the Boston Guardian, stating that after an evening of successive speeches, Clifford and Archibald Grimke "refused to speak due to lateness" when called to the podium. Despite the controversy, Clifford remained, becoming a member of both the National Committee of Management and the Address to the Country Committee. ${ }^{124}$ In the address, committee members stated:

We are fighting laws and executive rulings that discriminate against a man because of his race or color. We are fighting the sentiment that apologizes for or justifies such laws and rulings. We ought to be able to count on every Negro leader with a spark of self-assertion in him America for support. We are in the midst of a perilous crisis and the Negro who does not come forward and call for justice for his people at this time is a soulless, unimaginative creature whom no crisis would arouse and no duty inspire. ${ }^{125}$

Signed by the seventeen committee members, including Clifford, Alexander Walters, Max Barber, and William Monroe Trotter, the address criticized the infringement of African Americans' civil and political rights in the South, the dismissal of the black troops in the Brownsville affair, and Jim Crow Cars. Announcing another "Declaration of Independence," the men came out against both Theodore Roosevelt and Taft as the Republican candidate for the presidency and in support of Joseph Benson Foraker. ${ }^{126}$

The April meeting created tension between J.R. Clifford and other African-American leaders in West Virginia. During the 1908 election, there was a "bolt" or split among Republicans in the state. Following the sentiment of the National Negro-American Political League, J.R. Clifford joined the bolters in forming the Lincoln Republican party, supporting

\footnotetext{
${ }^{122}$ Boston Guardian, March 21, 1908; Fox, The Guardian of Boston, 111.

123 Pioneer Press, July 13, 1912.

124 “Philadelphia Conference,” Boston Guardian, April 11, 1908. For the Address to the Country, see Appendix VI.

${ }^{125}$ Boston Guardian, April 11, 1908.

${ }^{126}$ Boston Guardian, April 11, 1908.
} 
Joseph Benson Foraker for president and Arnold C. Scherr for governor of the state. The “regular” Republicans supported William Howard Taft for the presidency and C.W. Swisher for Governor. The Democratic opponents were William Jennings Bryan for President and Louis Bennett, an conservative Democratic and son of a former Confederate and Redeemer calling for the disfranchisement of black West Virginians. ${ }^{127}$

The Charleston Advocate (W.Va.), an African American newspaper which staunchly supported Republican Party nominees, claimed its “esteemed neighbor,” the Pioneer Press, had gone off "half-cocked.” The editor of the Advocate, John C. Gilmer, stated, "We do not support those whose policy is "rule or ruin"-who desert because they can not keep both feet in the trough forever and a day. If the Advocate bolted, it would be on more tenable grounds, its leaders being better republicans than those whose actions are endorsed by the Pioneer Press" and the editor of the Press "who is a republican-democrat-prohibitionist-Protestant-Catholic mugwump, who:

"Wires in and wires out, And leaves the people all in doubt, Whether the stake that made the track Was going south or coming back.”

Gilmer added, "We can not support a movement which threatens the supremacy of the republican party, and thereby, jeopardizes the manhood rights of the Negro in West Virginia.”128

Gilmer's concern stemmed from the insertion of two anti-Negro planks in the West Virginia Democratic Party platform. The “Jim Crow Plank” called for segregated coaches or compartments on common carriers; and the "Elective Franchise Plank" called for an amendment to the state constitution limiting the right to vote to whites only. The platform stated:

\footnotetext{
${ }^{127}$ Charleston Advocate, August 27, 1908; John Alexander Williams, West Virginia and the Captains of Industry (Morgantown, W.V.: West Virginia University Foundation, 1976), 127.

128 "Where We Stand," Charleston Advocate, July 30, 1908.
} 
Believing that the extension of the elective franchise to a race inferior in intelligence and without preparation for the wise and prudent exercise of a privilege so vital to the maintenance of good government was a mistake, if not a crime committed by the republican party during the reign of passion and prejudice following the Civil War, for political ends and purposes, we declare that the democratic party is in favor of so amending the constitution so as to preserve the purity of the ballot and the electorate of the state from the evil results from conferring such power and privilege upon those who are unfitted to appreciate its importance, as it effects the stability and preservation of good government. ${ }^{129}$

Democrats, including ex-Governor MacCorkle, Col. Joseph E. Chilton, and Col. John T.

McGraw claimed the planks would be suicide for Louis Bennett, the Democratic candidate for governor. William Jennings Bryan called for their removal and feared it could lead to a Democratic defeat in Indiana., Illinois, and Ohio. However, the Democrats' adoption of the planks was not a surprise. Democratic leaders tried to include anti-Negro planks in the 1904 platform, but failed. In addition, the neighboring states of Maryland, Kentucky, and Virginia all had segregated carriers, with Virginia passing disfranchisement legislation as well. In the Advocate, Gilmer criticized the Democratic platform, stating:

The democrats of West Virginia have not even the lame excuse for the adoption of these hostile planks as is advanced by their brothers of the same political faith in other states. There is here no fear of race domination, no friction between the races. West Virginia's population is not more than ten per cent colored, and these are slowly but surely emerging from the gloom of centuries of servitude. They are advancing appreciably, morally, and financially, and are standing firmly by the party of progress.

He then asked, "Would Prof. DuBois, Bishop Walters, Rev. Waldron, or Mr. Trotter still advocate the support of the democracy by the Negro? Not, we trust, in West Virginia, unless they have made peace with their God." He then wrote, "Hell room is too good for the Negro, wherever he may be located, who would vote for any democrat for any position." ${ }^{130}$ One week later, Gilmer reported, "Down in this end of the state, there are no bolters. Here republicans are republicans,"

\footnotetext{
129 "The Democrats Declare for Jim Crow Cars and Negro Disfranchisement."

130 “Jim Crown Cars and Disfranchisement," “An Opportunity for a Martyr,” and "Jim Crow and Disfranchisement Plank work of Republicans,” Charleston Advocate, August 6, 1908.
} 
and claimed that some of the older citizens who fearful of disfranchisement and Jim Crow would not be to happy "if Du Bois should drop into this neck of the woods with the intention of preaching democracy."131

When a list of officers of the National Negro-American Political League appeared in newspapers with Clifford's name on it, Gilmer wanted to know where Clifford stood in the political debate. With Rev. Waldron of Washington, D.C., head of the organization, urging blacks to support the Democratic Party, Gilmer asked, "Can Clifford support the Waldron movement and at the same time oppose Democracy in West Virginia or will he swallow both Bryan and Bennett?” Gilmer wanted Clifford to clarify his position and claimed that if the National Negro-American Political League wanted support in West Virginia, they had to force Bryan to get rid of the anti-Negro planks in the state Democratic platform. ${ }^{132}$

Clifford, who was not, and never could be, a Democrat, was in an awkward position. Although he was not happy with national or state Republican leaders, the Democrats in West Virginia were carrying on a bitter race campaign. In addition to the Democratic planks calling for disfranchisement and Jim Crow, in West Virginia, campaign organizers allowed only white constituents in lecture halls to hear Bryan's speeches; Democratic newspapers touted the perils of "mixed schools;" and Democratic leaders such as W.E.R. Byrne, a Charleston lawyer and one of the sponsors of the Democratic planks, made numerous inflammatory statements in their speeches and in the press. Bryne, in a statement to the Charleston Daily Mail, said "When we want the Negro votes we buy them. Yes, we buy them. We follow the lines of the least resistance when we buy them instead of shooting them." ${ }^{133}$ As a result, black leaders in the West Virginia

\footnotetext{
131 “If Du Bois Should Come to West Virginia,” Charleston Advocate, August 13, 1908.

132 Charleston Advocate, September 3, 1908; Charleston Advocate, September 10, 1908; Charleston Advocate, September 24, 1908.

${ }^{133}$ Charleston Advocate, April 2, 1908; Fairmont Times, August 6, 1908; Charleston Advocate, August 6, 1908.
} 
maintained that African Americans who voted the Democratic ticket would be "selling into political slavery his wife and children, and is selling to the enemy all the rights he has in the world.” Black West Virginians feared a bolt in the Republican Party guaranteed the Democrats a victory and placed not only their rights, but perhaps their lives, in jeopardy. Clifford did not believe the anti-Negro Democrats in West Virginia had enough support to carry out their plans, but he could not ignore the fears of his friends and neighbors.

Gilmer, who noted the presence of the Republican ticket and a cut of Glasscock in the Pioneer Press, reported in the Advocate that the "prodigal son" returned "to the home of his father," the Republican Party. Clifford, however, maintained, "We were for Scherr, and sympathize with him, just as we are and always will be for Foraker, but as it has been agreed on to support the new ticket—or a new head of the old ticket, we fall in line and do so, too, as an old soldier and Republican worker for forty years.”134 While Trotter was reporting in the Boston Guardian that "Many Negroes in spite of the Democratic position in the State [West Virginia], are not going to vote for Taft," and claiming that "Remember Brownsville is the slogan for these men," Gilmer insisted in the Advocate that "opposition to Taft died and was buried at least 3 weeks before election day—obituary and funeral notice appeared in the Pioneer Press, the only one of our five Negro papers opposing the Chicago nominee.”135 However, Clifford remained unhappy with the Republican Party and wrote, "While republicanism, as originally planned and for years carried out is imbedded in our bones, we feel it is our duty to purify and for the perpetuity of this government, to be strictly independent hereafter.” He then repeated a statement he had often made in the past, "hereafter we shall belong to no party and shall cut and slash our

\footnotetext{
${ }^{134}$ Charleston Advocate, October 15, 1908.

135 “The Bolt in West Virginia,” Charleston Advocate, November 19, 1908.
} 
ballot to suit our conscience." ${ }^{\text {"136 }}$

In the meantime, the Niagara Movement suffered without the exposure Trotter's Boston Guardian provided and the energy and spirit that Trotter and his supporters brought to the movement. In addition, Booker T. Washington and his "Tuskegee Machine” managed to limit or eliminate financial patronage and press coverage of the organization. As a result, attendance was poor at the 1908 meeting held in Oberlin, Ohio. However, Clifford continued to remain in both the Niagara Movement and the National Negro-American Political League. ${ }^{137}$

National Negro-American Political League held its second meeting in the spring of 1909 in Columbus, Ohio. With its reputation tarnished from its blatant support of the Democrats in 1908, attendance was low and those who did attend often failed to agree. The members elected Alexander Walters as President and renamed the league the National Independent Political League (N.I.P.L.) in an attempt to reassert their original intent and to distance themselves from those who obstinately committed the organization to Bryan. ${ }^{138}$

Still, Clifford's first love was the Niagara Movement. In a letter written to the secretary of the Niagara Movement in August of 1909, Clifford stated:

My heart is in the Niagara Movement, and I had never looked forward to any thing with as much joy, as meeting that body of manly men — men who will say and do things. I have been importuned to attend all of the National gatherings, but my ambition was to meet and mingle with the whipped cream of Negro manhood — men who have risen from injury to arms, and from arms to liberty. The confidence I have in you as a body, impels me to say, that anything you may say or do, will have my endorsement. ${ }^{139}$

Despite his loyalty, Clifford was unable to attend the 1909 meeting held in Sea Isle City, New Jersey due to a legal case. "All the lawyers being white," Clifford reported, "I don’t want it said

\footnotetext{
${ }^{136}$ Pioneer Press, November 21, 1908.

${ }^{137}$ Lewis, W.E.B. Du Bois, 375-377; Fox, The Guardian of Boston, 113.

${ }^{138}$ Fox, The Guardian of Boston, 162.

${ }^{139}$ Letter from J.R. Clifford to Dear Secretary and Comrades, August 16, 1909, W.E.B. Du Bois Papers, University of Massachusetts, Amherst, Massachusetts.
} 
that I was neglectful in doing my part.”140 Clifford continued to support the Niagara Movement through its last meeting held in 1910. Du Bois disbanded the group following the meeting, urging all former members of the Niagara Movement to join him in the newly formed bi-racial National Association for Advancement of Colored People (N.A.A.C.P.). Years later, a commentator on the Niagara Movement wrote, “Their cause was just, their motives pure, their goals noble and practical; but they were perhaps too far removed from the masses to inspire them to action- too conscious of their own privileged position as Black elite"-an honest reflection. ${ }^{141}$

The National Independent Political League, continuing to move away from both parties, held its third annual meeting the first week of August in 1910. President Alexander Walters or Rev. J. Milton Waldron invited W.E.B. Du Bois to speak along with Walters, Waldron, Rev. S.L. Corrothers, N.B. Marshall, Jr., defense attorney for the Brownsville soldiers, and W.F.S. Cook, son of the Cook hanged with John Brown. The meeting, described as "one of the most interesting and intellectual sessions ever held by free Negroes in this country,” had only sixty delegates in attendance. ${ }^{142}$ On September 28, 1910, the newly elected members of the Executive Committee along with the campaign committees met in Washington, D.C. to organize a program for political action. Members agreed to support Republicans in West Virginia and Delaware and Democrats in Ohio, New York, and New Jersey. Radical black leaders continued to be in agreement, with Du Bois writing from the pages of the N.A.A.C.P.'s Crisis, “If there is one thing that should be urged upon colored voters throughout the United States this fall it is independence."143

Clifford, who remained with the N.I.P.L. and did not immediately join the N.A.A.C.P. due

\footnotetext{
${ }^{140}$ Letter froom J.R. Clifford to Dear Secretary and Comrades.

${ }^{141}$ Lewis, W E.B. Du Bois, 439; Henry Lee Moon. Balance of Power: The Negro Vote (Garden City, N.Y.: Doubleday, 1948), 100.

142 “Political Movement," Charleston Advocate, August 25, 1910; Fox, The Guardian of Boston, 163.

143 “Along the Color Line,” Crisis, Vol. 1 No. 1 (November 1910): 11; Huntington Herald Dispatch, October 8 , 1910.
} 
to concerns over its white leadership and the use of the term "Colored" in its title, had favorable comments on the N.A.A.C.P. In February of 1911, he wrote, "The National Association for the Advancement of Colored People, is one of the greatest institutions since the spirit of the old Abolition party has waned. To us it looks like it is God's substitute for that once noble organization, and may he help it on and along, as he did its forerunners when so much was at stake.”144 However, Clifford continued his association with the more radical N.I.P.L. and aligned himself further with political leaders, particularly William Monroe Trotter who he reported on favorably despite Trotter’s brusque and controversial manner. In March of 1911, a white man, Henry Adams Ulrich, severely beat Booker T. Washington after accusing him of an attempted assault on a white woman in the demimonde district of Manhattan, New York. Clifford noted that Washington, while heavily criticized in the black press for not fighting back and remaining silent while he, the best known black man in America, was accused of assaulting a white woman, received unexpected compassion from Trotter. Clifford, cautioning readers not to judge Trotter unfairly, wrote:

Trotter has not always received the kindliest and most considerate treatment at the hands of Booker T. Washington and his friends, but his attitude toward the noted Tuskegeean since he came into contact with the brutal Ulrich has been especially commendable. Unlike many, both pro and anti-Washington, he has refrained from intemperate utterances, being satisfied to withhold judgment until the whole affair has been threshed out. Such conservatism shows Mr. Trotter to be a man of more than ordinary self control, at the same time proving that you have to know a man properly before placing him. ${ }^{145}$

One month later, he praised Trotter again stating:

Mr. Trotter is a credit to any nation, and is doing more than his part to correct wrongs and blaze the way for cowards and gropers. The Guardian is his mouthpiece, edited in the very room where William Lloyd Garrison edited the Liberator, and what Garrison was to destroy, chattel slavery. Trotter is to the destruction of a worse thing-

\footnotetext{
${ }^{144}$ Pioneer Press, February 11, 1911.

${ }^{145}$ Pioneer Press, April 8, 1911.
} 
political slavery and were he an Irishman or any other nationality he would be honored and revered from the oldest to the youngest. ${ }^{146}$

Composed of organizations and individuals of the race in various parts of the country who believe that colored Americans ought to use their ballots, the National Independent Political League sought to secure African Americans every right guaranteed them under the constitution of the United States. In May of 1911 Clifford wrote, "Clifford is free, thought he lives in a political slave country. He asserts his rights, through they are denied, and he enjoys them,” and then insisted that blacks must demand their rights and be determined to get them or die. John Mitchell, Jr. agreed with Clifford saying, "The facts above square with the truths of history. People who do not contend for rights denied cannot expect to get them, or if gotten, cannot expect to retain them.” In reference to Clifford and his role in the N.I.P.L., Mitchell added:

Supine submission only affords temporary relief, which is followed by even more vicious tortures. Editor Clifford is right in this, and the agitators are in a way doing the colored people of the country a service. White men respect manhood and they bow down at the shrine of valor. Heaven, in our judgment, is the better resting place when entered through the gates of manhood than when it is approached by the back gate of racial cowardice. The William Tell of West Virginia is all right in the position he taken and in the attitude he has assumed. ${ }^{147}$

Black newspapers across the country announced the fourth annual meeting of N.I.P.L. to be held from August 28 to August 31 at the Twelfth Baptist Church and Faneuil Hall in Boston, Massachusetts. The announcements reported that the league stood for men and measures rather than for any particular political party, contended for equal rights and opportunities for all American citizens, kept the minority party advised of treating black voters with fairness and justice, and proven itself effective in the 1910 congressional and gubernatorial campaigns with all five of its gubernatorial candidates and seventeen out of its twenty-five congressional candidates

146 “William Monroe Trotter,” Pioneer Press, May 6, 1911. 
elected. ${ }^{148}$ The Pittsburgh Courier reported that at the last national Executive Committee meeting held in Washington, D.C. following the 1910 conference, Bishop Alexander Walters resigned as president to become the presiding African Methodist Episcopal Zion bishop over the West Indies and West and South Africa and the committee elected a new president, J.R. Clifford, “a prominent lawyer, veteran editor, successful politician, fearless contender for the rights of the race and a Grand Army man of note."149

At the meeting, numerous speakers took the podium and women from the Women's Auxiliaries, including Ida B. Wells-Barnett, the women’s organizer in Illinois and Mrs. J.E. Givens, the Kentucky women's organizer, presented reports. Clifford, who was re-elected as the President of the National Independent Political League delivered a lengthy and fiery annual address in Faneuil Hall on August 30, 1911. ${ }^{150}$ He ended his message with the words:

I cling to and love the man who dares to stand alone in the right. It is one of The best ways to be popular with God; and I would rather be that, than to have The applause of the world and be popular with men. Silence, when protests are Needed is a crime and makes you a coward. Will you protest? Will you, if need $\mathrm{Be}$, stand alone in the right? ${ }^{151}$

The black press reported favorably on the meeting. John Mitchell, Jr., of the Richmond

Planet exclaimed:

The report of the National Independent Political League Meeting which was held in Boston last week has the right ring. The address to the country was a terrific arraignment of present conditions, disfranchisement, lynching and peonage. It contains the one clear note against these outrages which has been uttered by any national meeting of the race this summer. ${ }^{152}$

\footnotetext{
147 “Editor Clifford’s Opinion,” from the Richmond Planet and reprinted in the Pioneer Press, May 27, 1911.

148 “Potent Agency in Race Work,” Pittsburg Courier, July 29, 1911.

149 “Potent Agency in Race Work."

${ }^{150}$ Pioneer Press, August 12, 19, 1911; Boston Guardian, August 19, 26, 1911, 5.

151 “Annual Address.” For the complete “Annual Address” see Appendix VI.

152،"Wise Leadership,” Richmond Planet.
} 
In the Crisis, Du bois reported:

The most important event in the political world has been the meeting of the National Independent Political Rights League in Boston. The address to the country said 'In view of the extraordinary and alarming state of affairs we ask of the Federal Government in the interest of justice, equal rights and security of the country: (1) The enforcement of the Constitution to stop disfranchisement and peonage. (2) The passage of a Federal anti-Jim Crow law for interstate passengers. (3) Federal aid to education with the same schooling for all. (4) The restoration of the discharged Brownsville soldiers. (5) Legislation making lynching a capital offense under the Federal jurisdiction.' The election of Mr. J.R. Clifford, of Martinsburg, W.Va., to the presidency over W.M. Trotter, of Boston, caused some dissension; otherwise, the meeting was unusually successful. Much outspoken feeling against Mr. Taft developed. ${ }^{153}$

The Charleston, West Virginia Advocate also reported discord between Clifford and Trotter claiming: "Not a month ago, dear friends and co-workers in the National Independent Political League were closer than Damon and Pythias. Ambition stepped in-Trotter wanted to be president, Clifford got it. Both Trotter and Clifford are ambitious and thereby hangs a tale—a tale of woe-which is yet in the telling." ${ }^{154}$ However, despite rumors of Trotter's unhappiness and his desire for the presidency, Trotter wrote a glowing report of the meeting:

The National Independent Political League, which met in Boston, Mass. August 29, 1911, has adjourned, and Mr. J.R. Clifford, of Martinsburg, W.Va. was re-elected president. We have read the address to the country with interest, and we regard it not only as an able and timely production, but one which should be cordially approved and support by patriotic Colored men everywhere, regardless of party affiliations. It tells the truth, the whole truth, and nothing but the truth. We do not detect in this address though any taint of democracy, so far as that word relates to the present Democratic party. It advocates the support of men and measures which is an indirect way of saying that if a Republican nominee stands for the principles of the platform and will pledge support for the same, it is incumbent upon the Colored voters to support him, and if a Democrat, Prohibitionist, Socialist, Populist or the candidate of any other political party occupy this position, cast the support in their direction. This is broad, high ground, and it shows a breadth of statesmanship in striking contrast to the utterances of other days. It is evident that the platform of the Democratic party of our nation is not now, and will not be for decades to come, of a kind and character as will enable the membership of the National Independent Political League to stand upon it, if the address to the country is to be taken as a criterion.

\footnotetext{
153 “Along the Color Line,” Crisis, Vol. 2 No. 6 (October 1911): 245.

154 “A Tale of Woe,” Charleston Advocate, September 14, 1911.
} 
In our minds, it will be as interesting and embarrassing question for the management of this political organization to decide which of the presidential candidates it will support during the next campaign.

Gauged by its platform, its steering committee will be practically 'between the devil and the deep blue sea.' A way out may be found in the determination to support men and not parties, measures and not platforms. Taken all in all, we are of the opinion that the men at Boston who had a hand in shaping affairs have profited by past political experience and in drafting their platform showed remarkable skill and commendable judgment. Gauged from any angle, we are of the opinion that the race must be necessarily benefited. If the members thereof will observe scrupulously and follow with care the instructions given by those shrewd leaders, who were in charge of this remarkable meeting held in the city of Boston to outline the plan and to shape a policy for the guidance of one of the most remarkable race of people on the face of the globe. ${ }^{155}$ Clifford intended for the fifth annual meeting of the league to be held in Harpers Ferry.

Instead, the members voted to hold the convention at the site of its inaugural meeting, the Zion Baptist Church in Philadelphia, Pennsylvania on July 3, 1912. The N.I.P.L. announced that "every member of the race who is independent in politics and who believes in supporting men and measures rather than parties and who is a contributor to the League, is eligible to membership in the national body and to representation at the annual meeting.” Organizers argued that lynchings, race hatred, industrial discrimination, peonage, and exclusion from state militias were products of disfranchisement and could only be eliminated when African Americans learned to use their ballots to force political parties to provide equal rights, opportunities, and protection to all American citizens. In a show of unity, the N.I.P.L. asked for pastors of all African-American church denominations to preach a sermon on "The Evils of Disfranchisement and the Duties and Responsibilities of Citizenship” on Sunday June 30, 1912. They also requested congregations "to spend part of the day in prayer and fasting that God may turn from us and our beloved country, the threatening evils which hang like a pall in this Republic.”156

In Philadelphia, Clifford presided over the annual meeting where members voted to adopt

\footnotetext{
155 Boston Guardian, September 23, 1911.

156 “The National Independent Political League,” Charleston Advocate, June 27, 1912.
} 
the motto "For Men and Measures Rather Than Party.” The league also appointed a committee to interview the three men running for the presidency of the United States and to ask them the following questions:

1. Are you in favor of equal rights and opportunities for colored citizens, and will you contend for them if elected?

2. Are you opposed to lynching and lawlessness, and will you, if elected, labor to make lynching a crime against the national constitution punishable by the federal government?

3. Will you use every effort to have Jim-Crow car laws and disfranchisement amendments to the state constitutions abolished?

However, delegates to the conference refused to adopt a report of the executive committee, headed by Trotter and Waldron, condemning Theodore Roosevelt and President Taft and asking black Americans to support any presidential candidate who had the best chance of defeating the ex-President and his Secretary of War at the time of the Brownsville affair, President Taft. Clifford, who did not support the unmitigated endorsement, was the one who called for the floor vote that led to the proposal's defeat. Members then voted down a motion from Trotter and his supporters to disband the league on the grounds that the organization, in showing support for Theodore Roosevelt, had reversed its original purpose. Adding insult to injury, the delegates then voted to re-elect Clifford as President. Angry at Clifford's challenge to their leadership, William Monroe Trotter and J.M. Waldron, along with four other officers and a few of their followers, bolted from the league. The bolters included J.M. Waldron, the first president of the league and its national organizer for three terms; William M. Trotter, editor of the league’s official newspaper; William D. Johnson, Second Vice-President; Byron Gunner, Fourth Vice-President; and Emory T. Morris, a national committeeman. All of the men were charter members. Extremely bitter, the bolters left the church and held their own convention, one that adhered to what Trotter called the original purpose of the league, opposition to Roosevelt and Taft. The bolters chose Bryon Gunner as their president and re-elected the others to their respective 
offices. $^{157}$

The twenty-five members of the majority group chose not to endorse any candidate for president. The members then elected Rev. J.H. Wiley of Rhode Island, W.D. Johnson of Massachusetts, Rev. W.H. Jeonagan of Okalahoma, J.M. Summers, and J.G. Burrell as Vice Presidents; named Abel P. Caldwell, Corresponding Secretary; J. Jones, Treasurer; J.L. Neil, Recording Secretary; Rev. J.E. Churchman, Organizer; and made John Clinton, Jr., the Sergeantat-Arms. Reporting on Trotter's actions, Clifford stated, “Absolutely he is the weakest person to assume to advise, and the most selfish being we ever saw."158 Clifford later wrote in an editorial: Boston's 'hell-raiser' and 'crazy editor of the Boston Guardian' can paw and blow in Boston, but he would be a clam down in this neck of the woods, where it takes manhood to fight on real battle fields. Would he go to jail for his client? Would he be knocked down three times in a courtroom, go home and take off his bloody clothes, dress himself, go back and fight out his case? Would he take his bloody shirt and canvass his county, and go into the bandstand of our public square, in front of the Court House, with only four Negroes brave enough to stand by him, speak one hour and a half waving his bloody shirt? Would he go into the Court House where John Brown was tried and convicted, and ring the bell at 10 o'clock at night, appeal to a crowd that had broke up a meeting, and then, with John J. Dixon, as brave a Negro that lives, go through a crowd of 25 men who had gone a mile out of town to kill him, with two pistols in his hands? No, and no again! We did it, and the cowards yelled: 'Three cheers for Clifford, the bravest Negro in West Virginia. It is one thing to brag in Boston; quite another thing to fight the battles of life down here. ${ }^{159}$

The National Independent Political League was now divided into two leagues: a majority league endorsing no candidate, but leaning toward Roosevelt; and a minority league supporting the Democratic candidate, Woodrow Wilson. The Charleston Advocate, reporting on the split, claimed that the league was "an ambitious organization of men of color with a name more pretentious than its membership" and that since its organization in 1908, it "had been more

\footnotetext{
157 “Rev. Waldron Leads Bolt,” Charleston Advocate, July 11, 1912; “League Renews Fight Against Jimcrowism,” Pittsburgh Courier, July 19, 1912; “Along the Color Line,” Crisis, Vol. 4 No. 4 (August 1912): 165-166.

${ }^{158}$ Pioneer Press, July 13, 1912.

${ }^{159}$ Pioneer Press, July 20, 1912. See Appendix VIII for an N.I.P.L. statement with the bolters names marked off of the stationary heading. See Appendix IX for a list of resolutions adopted at the 1912 N.I.P.L. meeting.
} 
Democratic than Independent.” Perhaps expressing the confusion and difficulty confronting all African Americans in search of an organization or party affiliation that could ameliorate the conditions facing black Americans in the era of Jim Crow, the editor of the Advocate declared, "Let them split ... Old lines are being broken up, ancient land-marks obliterated and customary moorings deserted.”160 Politically, African Americans were still searching for a place to call home.

160 “Everybody’s Doing It,” Charleston Advocate, July 11, 1912. 


\title{
CHAPTER FIVE
}

\author{
“STAND UP LIKE MEN:" \\ Profit, Protest, and Politics
}

"Some may say you have no country to fight for. It's a lie. The Negro's title to this land is decreed by God Almighty, hence, he must fight to right its wrongs."1

In January of 1910, U.S. Commissioner T.T. Lemen of Martinsburg, West Virginia sent J.R. Clifford to jail for his persistent defense of a client. The case began on January 22, 1910 when U.S. Marshal W. Dorsey Brown arrested an African American named Benjamin Carter for selling whiskey without a license. Carter, a twenty-four-year-old section hand on the Baltimore \& Ohio Railroad, called Clifford and engaged him as his attorney after appearing before Lemen. Clifford arranged to continue the hearing until two days later on January 24, 1910 at two o'clock in the afternoon so he could subpoena witnesses for Carter. On January 24, Clifford went to Lemen and asked him to subpoena additional witnesses; witnesses that both Clifford and Lemen knew could discredit the only witness against Carter. Lemen refused to subpoena the witnesses and threatened to lock up Clifford if he continued to contend for them. When Clifford asked for the subpoenas again, Lemen told Constable Wild to take him out of his office and lock him up. Imprisoned for one hour and twenty-nine minutes, upon release Clifford discovered that Lemen held the hearing without him, bound his client, Carter, over for the grand jury at Wheeling, and placed him in the Martinsburg jail. Clifford immediately had Carter released on bail and decided it was time that someone put a stop to the barefaced graft and corruption being practiced in the federal court at Martinsburg. ${ }^{2}$

\footnotetext{
${ }^{1}$ Pioneer Press, July 26, 1913.

2 “J.R. Clifford Put in Jail,” Pioneer Press, January 29, 1910, in Record Group 60, Box 1016, File 150188, United States Department of Justice (hereafter U.S.D.J.), Library of Congress; Letter from J.R. Clifford to Attorney General George W. Wickersham, February 4, 1910, U.S.D.J.; Report of Special Examiner M.C. Masterson to U.S. Attorney General George W. Wickersham, February 26, 1910, U.S.D.J., 1-19.
} 
According to Clifford, the federal court convened in Martinsburg twice a year, where those arrested on federal charges went before a grand jury and were tried if indicted. For several years, Wilbur H. Thomas was the only U.S. Commissioner in Martinsburg until his reappointment on October 20, 1909, when Judge Alton Dayton appointed a second commissioner, T.T. Lemen, who was also a Berkeley County Justice of the Peace. Following his appointment, T.T. Lemen and U.S. Deputy W.D. Brown engaged in a scheme to defraud the government of thousands of dollars that resulted in innocent men being sent to jail. ${ }^{3}$

The fraudulent scheme began on July 16, 1909, when Deputy Marshal Brown arrested a man named John Ross for illegally selling liquor. Brown took Ross before U.S. Commissioner Wilbur H. Thomas who held the defendant over for the grand jury at Martinsburg and released him on a $\$ 200.00$ bond. Deputy Brown wanted Ross taken to the next session of the grand jury being held in Wheeling, West Virginia. Brown received "fees" for his transporting prisoners to other cities for trial, ten cents per mile for himself and ten cents per mile for the defendant, plus room and board. Brown insisted that he would not take any more prisoners before Commissioner Thomas and recommended to Judge Dayton that T.T. Lemen also be appointed to the position of commissioner. Lemen was willing to send all prisoners to the grand jury in Wheeling or Parkersburg, as much as 300 miles away, rather than holding them for one of the two sessions held yearly in Martinsburg. As a result, Deputy Brown took everyone he arrested before Lemon, leaving Commissioner Thomas with no cases. The two men, U.S. Commissioner Lemen and U.S. Deputy Brown, began paying a disreputable African American named Lester Tutt to claim that various black workers illegally sold him liquor and to testify against them court. Tutt received money for travel as well, while, as Clifford reported, "most all of the persons arrested are too

\footnotetext{
3 “J.R. Clifford Put in Jail;” Letter from J.R. Clifford to Attorney General George W. Wickersham.
} 
poor to take lawyers and witnesses to those far off places” and the only person they knew was the one "who took them there hand-cuffed" and quietly urged them to plead guilty for their own sake. Clifford maintained that when he arrived in Parkersburg in early January of 1910 to defend a man, Deputy Marshal Brown pointed out another man and asked Clifford to "Go over there and tell him to plead guilty.” As Clifford said, "He missed his man," and refused. ${ }^{4}$

Benjamin Carter's arrest, along with Clifford's, was simply the latest of a series of illegal actions taken in Lemen's court. Clifford reported the incident in an article titled "Clifford Put In Jail” printed in the Pioneer Press on January 29, 1910. On February 4, he sent a letter along with a copy of his article to United States Attorney General George W. Wickersam, describing the corruption in the federal court at Martinsburg and asking that Lemen and Brown be investigated. At Clifford's request, U.S. Commissioner Thomas also sent a letter to the Attorney General on February $10 .^{5}$

Following M.C. Masterson’s investigation, the federal government dismissed Deputy Marshal W. Dorsey Brown from his position and the court forced T.T. Lemen to resign. Lemen left office on March 14, 1910. However, Lemen retained his position as a Justice of the Peace in Berkeley County. ${ }^{6}$ On August 7, 1910, Constable W.S. Wild, who locked up Clifford on January 24 in the Carter case, arrested Clifford on the charge of unlawfully trespassing "on the trains of Baltimore \& Ohio Railroad (B \& O) by riding on said train without having a ticket or a pass” and brought him before Justice Lemen who postponed the hearing until August 12. At the hearing, Clifford and his lawyer filed a motion to have Lemen replaced with another justice based on an

\footnotetext{
4 “J.R. Clifford Put In Jail."

5 "Bootlegger Arrested," Martinsburg Independent, January 1, 1910; Letter from J.R. Clifford to Attorney General George W. Wickersham, February 4, 1910, U.S.D.J.; Letter from Wilbur H. Thomas to Attorney General George W. Wickersham, February 10, 1910, U.S.D.J.

6 “U.S. Commissioner Removed,” Martinsburg Statesman, March 18, 1910; “Department of Justice is After Lester Tutt,” Martinsburg Herald, February 26, 1910; “Lemen Removed as Commissioner,” Martinsburg Independent
} 
affidavit Clifford wrote and filed against Justice Lemen stating the justice could not "render a fair and impartial judgment” based on the Carter case and Clifford's subsequent actions to have Lemen fired from his position as a U.S. Commissioner. The court denied the motion and Justice Lemen found Clifford guilty and ordered him to pay the fine plus court costs for the justice, constable, and witnesses. Clifford also posted one hundred dollars in bond to appeal the case. ${ }^{7}$ Once again, he had to spend valuable time and money that he needed for the Pioneer Press in order to fight his enemies.

That year Clifford also witnessed renewed efforts among Democrats to create Jim Crow and disfranchisement legislation against black West Virginians. Notices, calling for African Americans to organize in order to prevent the Jim Crow and disfranchising scheme of a "shallow headed democrat at Charleston,” appeared across the state. Clifford maintained that such legislation would never be passed because there were "too many broad-minded democrats" who would adamantly oppose the legislation and that Democrats knew that "many colored people, sick and tired of the treatment of a certain class of republicans, voted for the change, and if treated as promised they would be, they would vote again.” He then added that even if the legislation passed, "Wm. E. Glasscock, one of the best governors in the United States would veto them, and the Negroes would unifically [sic] go back to their 'first love."”8

In January of 1911, black West Virginians once again heard rumors that State Senator French intended to introduce Jim Crow legislation to the State Legislature. Clifford wrote, "If the democratic party has enough of that class and caliber of French's in it, to pass such a muddle

\footnotetext{
March 19, 1910.

${ }^{7}$ State v. Clifford, August 12, 1910, Berkeley County Circuit Clerk’s Office, Berkeley County Courthouse, Martinsburg, West Virginia.

8 “Don’t Be Scared,” Pioneer Press, January 28, 1910.
} 
of words - which boiled down aims to bring back the old slave customs---for it provides that servants and criminals may ride with his class---it is doomed.” However, the editors of the McDowell Times asked for a meeting of black West Virginia editors over the "alleged design of Sen. French to introduce a Jim Crow Car bill to the legislature.” Rumors became reality when Senator French introduced a separate car bill on the final day of a rump senate; but the bill found little support, even among Democrats. At the same time, French introduced a registration bill designed to disfranchise black voters. Under French's registration bill, three free-holders had to vouch for any challenged voter in order for the voter to cast his ballot. The Charleston Advocate reported, "Its operation in precincts in the coal-fields would favor any party inclined to exercise its prerogatives. Most of these precincts have none but voters who live on property owned by coal companies. Before a challenged voter could get three free-holders to vouch for him, the cows would come home from the Milky Way.",

Clifford, in his usual defiant and pragmatic way, made a statement that would have great

significance for African Americans in the future, particularly for members of the black press:

If the Democratic party has enough mean white men in its ranks to pass a Jim crow car bill, let it be done, for sure as 2 and 2 are 4, it will be undone, or the state of West Virginia will have the only class of Negroes to live in it the South wants, has, and is telling the world is a festering hell — the ones whose manhood has been crushed out and whose blood is flooded with servility. It drove from Virginia some of its best women and men, and it will do the same if it passes in West Virginia.

The Negroes must go and ally themselves with a better class of white people. Germany declares she could take the American Negroes in war and compete with the world and Japan has made overtures to them, as has France. Unless treated right here, our advice is go everywhere-especially where you are treated the best; and wherever you go trust in God and be manly men and womanly women. ${ }^{10}$

Although Clifford's words had little impact in 1910, comments such as the one above were to

\footnotetext{
${ }^{9}$ Pioneer Press, January 4, 1911; “The Editor’s Conference,” Charleston Advocate, January 19, 1911; “Rattling Dry Bones,” Charleston Advocate, February 2, 1911; “Another Way to Disfranchise,” Charleston Advocate, February 16, 1911.
} 
gain increasing significance in the years leading up to World War I. With war on the horizon, bitter expressions over the nation's failure to halt the entrenchment of Jim Crow, whether de jure or de facto, often led to suspicion and charges of national disloyalty.

Attempts to pass a Jim Crow measure in February of 1911 came and went so often in West Virginia that John Gilmer of the Charleston Advocate claimed that the Jim Crow bill seemed to have "the reputed nine lives of a cat, being killed one day and coming to life the next." Delegate Williams from Raleigh County introduced a segregated car bill, but the House rejected it. However, a motion to reconsider prevailed and the measure advanced to a second reading. After numerous speeches for and against the measure, many Democrats as well as Republicans voted against the bill, killing it. The following morning, advocates of the Jim Crow bill made a motion for a reconsideration of the vote that failed due to time limitations. Delegate F.H. Kidd from Braxton County revived the issue again the following Monday. However, delegates killed House Bill No. 359 calling for Jim Crow legislation on common carriers with a bipartisan majority of forty-four voting against the bill and twenty-nine voting in favor of the segregated cars. ${ }^{11}$

Of more concern to black West Virginians was an article titled "Secret Societies" inserted in House Bill No. 218. In it, Senator Carr introduced legislation that could have severe repercussions for the black community. The bill called for the removal of all black fraternal names, banners, badges, and regalia based on white fraternal societies, thereby eliminating such African American organizations as the Masons, Knights of Pythias, Odd Fellows, Elks, and Red Men. The dissolution of such fraternal orders would deprive African Americans of the benefits of their charity, reduce efforts at self-help and moral advancement, and eliminate burial funds that afforded protection to black families upon the loss of a loved one. Although blacks met with

\footnotetext{
${ }^{10}$ Pioneer Press, February 18, 1911.
} 
legislators on the issue, the House of Delegates passed the Carr Bill sixty-four to four, with Republicans as well as Democrats voting in favor of the legislation. ${ }^{12}$

At the end of the session, the State legislature adjourned without passing a Jim Crow car bill; the Carr Fraternity Society Bill failed to pass its first reading in the West Virginia Senate; and to the relief of all black West Virginians, the legislature did not address the issue of disfranchisement. In addition, the state legislators passed House Bill No. 17, agreeing to purchase and maintain the Colored Orphan’s Home in Huntington, West Virginia as a state institution. Although the state failed to pass discriminatory legislation against black West Virginians, the Charleston Advocate reported, "West Virginia still stands at the head of the states providing for the separation of the races in educational and charitable institutions, as the appropriations bill recently passed will attest.”13

At the end of February, Clifford, along with a white friend, applied to become a member of the Martinsburg post of the Grand Army of the Republic (G.A.R.). Despite his service in the Union Army during the Civil War, the members rejected Clifford’s application. One Republican member of the post told him, "You've got a hell of a lot of gall—by God Damn, if you were made white as snow and fell from Heaven we would not let you in.”14 Clifford recognized that if Democrats in the state intended to pass Jim Crow legislation as soon as they had enough power to do so, the best thing for black West Virginians to do was to "rally around for the G.O.P. in November of 1912” because every Republican in the state senate voted against the legislation. ${ }^{15}$ However, his previous experience with local Republican Party leaders, the increase of Jim Crow

\footnotetext{
${ }^{11}$ Charleston Advocate, February 23, 1911; “How They Voted On Race Measures” and “Some Class To This Bill,” Charleston Advocate, February 23, 1911.

12 “Pie Crust Promises,” Charleston Advocate, February 16, 1911; "How They Voted on Race Measures,” Charleston Advocate, February 23, 1911.

13 “Restrictive Legislation,” Charleston Advocate, March 2, 1911.

14 “Comparison Odious,” Pioneer Press, February 25, 1911.
} 
and disfranchisement under Republican leadership in the last decade, and his recent rejection as a member of the G.A.R., most of whom were Republican, left him cautious. He emphasized, "There is no hope for the race in being fool hardy republicans" and that the "right thing for every brave negro to do, is to oppose all infringements on his rights by any and all parties at any cost."16 Clifford vowed that he would rather support and vote for a known political foe, than for someone who posed as his friend, but stabbed him in the back at every opportunity. ${ }^{17}$

In the spring of 1912, Clifford was uncertain if he could support either party, Democrat or Republican, but he was certain of his political purpose. Clifford wrote, "The editor is an honest Republican and has always been, but when he knows his color was changed by force of duty to this world, and that his color was fixed before he was a Republican, his duty is to fight and die for his color's rights; which he will do to the end of his life." ${ }^{18}$ Feeling that there were no benefits associated with party affiliation and that parties simply used black men to their own advantage, he insisted that the duty of black men was to use the parties, giving them no more allegiance than they gave to African Americans. Clifford told his readers, "The greatest and noblest party that you can serve, is your own unflinching manhood."

As a radical integrationist and president of the organization, Clifford remained committed to the all black National Independent Political League. However, he was also supportive of W.E.B. Du Bois and his inter-racial N.A.A.C.P. Maintaining that the race would be far better off if it had more men like him, Clifford wrote of Du Bois, "He it is, who utters soul-stirring thoughts that awaken shades of the necessary determination that we make manly men. Oh, for ten

\footnotetext{
${ }^{15}$ Pioneer Press, March 11, 1911.

${ }^{16}$ Pioneer Press, May 13, 1911.

${ }^{17}$ Pioneer Press, May 20, 1911.

${ }^{18}$ Pioneer Press, May 25, 1912.

${ }^{19}$ Pioneer Press, June 3, 1911.
} 
thousand like him.,20 In May of 1912 when the N.A.A.C.P. held its fourth annual meeting in Handel Hall at Chicago, Illinois, Clifford reported that "much good was accomplished.” He identified the N.A.A.C.P. as "the most powerful organization on earth for the good of the American Negro" and that it was "to take up that which those old abolition saints left undone. If this be true, great will be the end." Calling the Crisis a classy monthly, "one of the best magazines published," and "an incentive to Negroes to be and do something," he encouraged all African Americans to read the publication. Clifford also added that if every white man, woman and child in the country read the magazine, it would not only provide a mighty awakening to them, but "put the Negro in a light before them which he has never occupied before." In a heartfelt expression of support, Clifford publicly thanked God for the existence of the National Association for the Advancement of Colored People for making the Crisis possible, but he was still reluctant to put his faith in a predominantly white led organization ${ }^{21}$

In the 1912 presidential campaign, Democrats ran Woodrow Wilson, an elite Southerner with all of the South's inherent prejudices of race and class. During his presidency at Princeton University from 1902 to 1910, Princeton was one of the few northern colleges to exclude African Americans. Among Republicans, the forerunners were ex-President Theodore Roosevelt and his former Secretary of War and the incumbent President, William H. Taft. After assurances from Wilson, many of Clifford's associates including Bishop Alexander Walters, at that time President of the Colored Democratic League, William Monroe Trotter, Max Barber, J. Milton Waldron, and even W.E.B. Du Bois, at Walters’ urging, gave their support to Wilson. Their position was unsurprising; their distain for Taft led the majority of those men to vote Democratic in the 1908 election. Clifford, however, was unwilling to throw his support to Wilson if there was any

\footnotetext{
${ }^{20}$ Pioneer Press, June 3, 1911.
} 
possibility that Teddy Roosevelt would win the Republican nomination over Taft. Despite the Brownsville episode, Clifford maintained a fondness for Roosevelt. It was Taft he blamed for the Brownsville Affair, growing disfranchisement and Jim Crow, and the rise of Lily-white Republicanism in the South. ${ }^{22}$

For a while, it appeared as if Clifford was going to get his wish. Throughout the spring of 1912, Theodore Roosevelt swept the presidential primaries. However, at the Republican National Convention held in Chicago from June 18 to 22, 1912, Taft controlled the national convention delegates, thereby gaining the majority of electoral votes and winning the Republican nomination for president. Roosevelt accused Republican Party leaders of fraudulently seating delegates who favored Taft and asked all of his progressive Republican supporters to walk out of the convention on the last day. Deciding to run as a third party candidate, Roosevelt formed the Progressive or “Bull Moose” Party and called for a national convention to be held in Chicago in August. Delighted, Clifford believed he found exactly what he was searching for so it was not surprising that he balked at the attempt of Trotter and Walters to repudiate Roosevelt completely at the National Independent Political League meeting held in July of $1912 .^{23}$

In West Virginia, progressive Republicans opposed to political bosses Stephen B. Elkins and Nathan Scott established the political "machinery to place West Virginia in the Progressive camp” and the Progressive Party won the support of not only the Pioneer Press, but John C. Gilmer's Charleston Advocate and the West Virginia Register. Although the Progressive Party did not mention blacks in its platform, Clifford and Gilmer both felt its principles were broad and comprehensive, leaving no doubts concerning its inclusion of African Americans. At home, state

${ }^{21}$ Pioneer Press, June 4, 1912; Pioneer Press, July 6, 1912.

22 Rayford W. Logan, The Betrayal of the Negro From Rutherford B. Hayes to Woodrow Wilson (New York: Da Capo Press, 1997), 362-364; David Levering Lewis, W.E.B. Du Bois: Biography of a Race, 1868-1919 (New York: Henry Holt \& Company, 1993, 422-424; Pioneer Press, December 10, 1912. 
Progressives placed five blacks on the state committee, more than the Republicans who could not be persuaded to have more than three. Among the delegates from West Virginia chosen to attend the National Progressive Convention in Chicago on August 6, 1912 were two African Africans, John C. Gilmer and C.H. James, a Charleston businessman. ${ }^{24}$ Gilmer and James met Roosevelt at the convention and when Roosevelt addressed the black delegates, he included both of the men in his statements. Both men endorsed Roosevelt and the Progressive Party with Gilmer reporting the "Republican party may have set the Negro free from physical slavery, but has kept him in a state of political peonage every since” and that since Roosevelt assured the black delegation that the Progressive Party would protect the constitutional rights of African Americans, "the Negro voter must look to the Progressive party for his future salvation.”25

Clifford, who also attended the convention, claimed that he could not remember entering "into a new movement with more zest and zeal" than he did when entering the Progressive movement. He reported that he "caught the inspiration in Chicago when Jane Addams, with the stars and stripes in her hands, arose, started a march in which thousands joined around that immense hall, stepping to the tune of 'Onward Christian Soldiers.'” Later that evening, more than a hundred of the Southern Progressives attending the convention invited men and women from the other regions to join them in a meeting at the Congress Hotel. Shortly after they arrived, a man from Louisiana began a bitter tirade against Negroes, but Jane Addams, who was sitting next to him arose and "with a beck of her angelic hand, marched out of the hall" with the other guests

\footnotetext{
${ }^{23}$ Logan, The Betrayal of the Negro, 362-364; Lewis, W.E.B. Du Bois, 422-424; Pioneer Press, December 10, 1912.

24 “'Bull Moose’ Party Forms” Charleston Advocate, August 1, 1912.

25 "The Negro Question, Attitude of the Progressive Party Toward the Colored Race; Colonel Roosevelt’s Reply to a Query at the Progressive National Convention; His Letter to Julian Harris, of Atlanta, and the Statement of All the Negro Delegates to the Convention,” (New York: Stoddard-Sutherland Press, 1912), 4; “'Roosevelt Outspoken'Praises for WV" and "'Negroes Endorse Progressive Stand'-J.C. Gilmer and C.H. James sign endorsement of party and TR," Charleston Advocate, August 15, 1912; "W.Va. Delegates in the Limelight," Charleston Advocate, August 15, 1912; "Statement from Colored Delegation,” Charleston Advocate, August 22, 1912.
} 
following, leaving the Southern "alleged Progressives" alone in the hall. At that moment, Clifford solemnized his commitment to the Progressive Party and when he returned to West Virginia, he boldly announced he was a Progressive and immediately entered the ranks. ${ }^{26}$

That fall, Clifford and his Pioneer Press vigorously campaigned for Roosevelt and, in the process, challenged any Negro “Taftite," preferably an office holder, to a debate. Challengers had to argue against Clifford's thesis: “Theodore Roosevelt is a better man for the American Negro to support in the pending contest for Chief executive than William Howard Taft or any other candidate.” During the debate, the audience was to act as jury and to decide which orator had the better argument and it was understood that it was the defeated party's responsibility to pay the rent on the hall or church along with all "incidental expenses." ${ }^{27}$ In the Press, Clifford recalled watching Theodore Roosevelt stand in a convention hall in Chicago, Illinois in 1884 fearless contending for John R. Lynch to be made temporary chair at the National Republican Convention. Claiming that men must give credit where it is due, Clifford declared, "No one can, or shall mistake Clifford for anything but a Roosevelite. ${ }^{, 28}$ In campaign addresses, he asked:

Who investigated the Brownsville episode, found the Negro soldiers guilty and did not only recommend their discharge, but said afterward—it is said — that the punishment was not sever enough; who warned a committee of colored men in Ohio as to their danger of supporting democracy because of the liability of democrats being appointed on the U.S. Supreme Court, and when he got in appointed three democrats. Did he open his mouth in condemnation of the Atlanta riot? Has he done anything to stop disfranchisement, jimcrowing and other outrages perpetrated by the South? No! and no again!! But has by silence encouraged them, and so help us God, if all the money in the United States Treasury was offered to the editor of this Pioneer Press to support Mr. Taft, he would not do it. ${ }^{29}$

Black West Virginians, still concerned over Democratic attempts to pass Jim Crow

\footnotetext{
26 “A Challenge,” Pioneer Press, September 28, 1912.

27 “A Challenge,” Pioneer Press, September 28, 1912.

28 Pioneer Press, September 28, 1912.

${ }^{29}$ Pioneer Press, September 28, 1912.
} 
legislation in the state, chose to support Republican candidates at the local level. Claiming that black West Virginians had never been given their full rights, Clifford hoped the decision would suppress the erosion of civil rights in West Virginia that occurred elsewhere in the South. He stated:

I was a soldier in the war of the rebellion, and fought for the rights of an American citizen, and after victory, amendments were added to the constitution guaranteeing the,; but the same force I, and 189,000 more Negroes put in power, made against me and mine black statutory laws - my own state for example, and I have never enjoyed half the rights fought for and faithfully promised. ${ }^{30}$

In a compromise, the Progressive and Republican parties in West Virginia carried the same candidates for state and local positions, but supported their own national candidates, Roosevelt and Taft. Clifford referred to the arrangement as "an example for the whole country,” as voters could cast their ballots for their presidential choice and, at the same time, vote the entire republican ticket at home. As a result, he claimed, "Truly we West Virginians are indeed— Freemen. ${ }^{31}$ As for the black West Virginians who chose to side with West Virginia’s political bosses and vote for Taft on the national level, Clifford offered a small, but somewhat sarcastic, truce:

The Republican prosperity of the past has been distributed among the favored few, true enough that a few Negroes have been benefactors and if those few benefactors can justify themselves for having surrendered the rights of their race in order that they might accept the purchase price, they then ought to be permitted to rest in peace. ${ }^{32}$

After hearing Dr. Henry D. Hatfield, the Republican (and Progressive) ticket candidate for Governor, speak at Majestic Park in Martinsburg, Clifford began campaigning for him in the Pioneer Press. Claiming that his style of address "catches and holds attention, and he impresses you as a man who is sincere, intelligent and vigorous," Clifford argued that Hatfield was the

\footnotetext{
${ }^{30}$ Pioneer Press, October 12, 1912.

${ }^{31}$ Pioneer Press, October 19, 1912.

${ }^{32}$ Pioneer Press, October 12, 1912.
} 
"truest and best friend of the negroes in West Virginia." Calling Hatfield "a manly man, in all the phases of manhood," he urged black West Virginians to vote for Hatfield to save their rights and claimed that a vote for Roosevelt, Johnson, and Hatfield would lead to intelligent and constructive administrations on both the national and state level. ${ }^{33}$

Along with campaigning, two other issues claimed Clifford's time and attention in the fall of 1912. A reinstated U.S. Marshall W.D. Brown was again using "a gang of crapshooters and card players to accuse decent, industrious blacks of bootlegging." Calling them pimps, Clifford claimed those "crooks" made forty dollars a trip and up to a hundred dollars a week for travel and per diem simply for swearing that another man is a bootlegger and then traveling to Parkersburg, Clarksburg, Philippi, or Wheeling to testify against the accused_-"pie for a few black and white niggers. ${ }^{34}$ Most of the men indicted for bootlegging were on their way home from work when Brown arrested them based on the lies of "two white fellows." During their arrest, Brown told the men not to hire Clifford as their attorney; but they did, leading Clifford to spend much of his time in the courtroom. ${ }^{35}$

Of more concern to Clifford was a lynching that took place in Princeton, West Virginia. Despite ample evidence that Robert Johnson was guilty of an attempted assault on a fourteen year old girl, the child's father led a mob of over 1,000 whites in lynching Johnson. Hanged from a telegraph pole, the crowd riddled his body with rifle and revolver shots. Following the lynching and the arrest of the girl's father, all of the black businesses located on Raleigh Street in nearby Bluefield received letters signed from a "Lynching Committee” telling them to leave town or there businesses would be dynamited. African Americans in Bluefield appealed for protection to

\footnotetext{
33 Pioneer Press, October 12, 1912; Pioneer Press, October 26, 1912.

${ }^{34}$ Pioneer Press, September 7, 1912.

${ }^{35}$ Pioneer Press, September 7, 1912. Ex-Congressman Woodyard had Brown re-instated to his position as a federal marshal.
} 
state and local officials who feared an all out race war in the town. When officials released the girl's father on a ten thousand dollar bond, hundreds of sympathizers gave him an ovation the Charleston Advocate described as a "frenzied delight” showing their approval of the mob’s act. ${ }^{36}$ Clifford vigorously condemned the lynching of Robert Johnson as well as the threats made against African Americans living in Bluefield who had nothing to do with Johnson’s “alleged” crime; a crime that he claimed was "more than likely committed by a "pale face blackened.”37 The grand jury refused to indict anyone for the lynching of Robert Johnson. ${ }^{38}$

Despite his allegiance to the Progressives and his decision to vote for local Republicans in the fall election, Clifford continued to support a few Democrats who voted to protect black rights, especially Cleveland Siebert who Clifford touted as the one who defeated the Jim Crow bill introduced in the previous legislative session. When a pronounced Negro Democrat named Syphax came to Martinsburg, Clifford offered to find him a place to speak and to protect him, just as he did J.W. Dunjee back in 1876. In addition, the Pioneer Press adhered to its policy of printing differing opinions from those in the black community. For instance, in a letter to the Press, Reverend N.H. Fields of Elkins argued that the only ticket blacks should vote for was the Socialist Ticket "because it's the one that wants to help the class he belongs to- the working class.”39

Progressives carried the state of West Virginia in the election, but nationally, the Republican split that led to the rise of Roosevelt's “Bull Moose” Party resulted in the election of Democrat Woodrow Wilson to the United States presidency. Despite Clifford's disappointment

\footnotetext{
36 “Lynchers Terrified,” “Lynched Negro May Be Innocent of Crime,” “Mob Rushed Jail and Lynched Negro,” and “Negroes Receive Orders,” Charleston Advocate, September 12, 1912.

${ }^{37}$ Pioneer Press, November 16, 1912.

38 “No Action Taken Against Lynchers,” Charleston Advocate, 26 September 26, 1912.

${ }^{39}$ Pioneer Press, September 7, 1912; Pioneer Press, November 16, 1912; “The Negro and the Socialists,” Pioneer Press, October 19, 1912.
} 
over “Teddy's” loss, he delighted in the fact that Wilson won and Taft went down "under the idea and shameful absurdity of getting only 12 electoral votes.” Of Wilson, Clifford stated, "He is my president and I will be as loyal to him as I was to my army officers” and that while he preferred Roosevelt, he hailed the breaking away of the Negroes from the dead and dying limbs of the old party. ${ }^{40}$ He concluded by saying:

We do not emphatically declare to the world that the Press has always been fair, but we do that it tried to be. It could not blame any one for being independent in politics, for it has been that since 1884; since when, men and not parties, has been its slogan. And it is broad enough to allow other men to do as they see fit. We have voted for democrats and expect to long as we live, when we knew they were manly men, and we have voted against republicans because they were not men. ${ }^{41}$

In January of 1913, Clifford boarded a train for Parkersburg and then on to Charleston for a meeting of the State Committee of the Progressive Party. Blacks serving as state committeemen included Clifford, T.H.A. Moore of Clarksburg, T.L. Sweeney from Fayetteville, J. Rupert Jefferson of Clarksburg, S. B. Moon of Wayco, and C. H. James, At Large, from Charleston. In Charleston, J.C. Gilmer, editor of the Advocate and the State Librarian, treated Clifford “royally.” However, Clifford reported that he received the most joy from addressing a group of over thirty women "“"who had caught the spirit of the Progressive party and want to vote.”42 At the meetings, the committeemen voted against a caucus to elect a United States Senator, saying they had "had too much of Elkins and Scottism in our state.” When he returned to Martinsburg, he reported in the Pioneer Press that he was an Abraham Lincoln and U.S. Grant Republican in principle, "but since they combined on the dollar to the destruction of my rights, I have voted for men, not parties, and finally joined with the human salt of the earth, the Progressive party.”43

\footnotetext{
${ }^{40}$ Pioneer Press, November 16, 1912.

${ }^{41}$ Pioneer Press, November 16, 1912.

42 “As We Saw Things” Pioneer Press, January 18, 1913; Pioneer Pres, January 18, 1913.

${ }^{43}$ Pioneer Press, January 18, 1913; Pioneer Press, February 1, 1913.
} 
Back in Martinsburg, Clifford engaged in the same old battles that continued despite his numerous attempts to vanquish them. Deputy Marshal W.D. Brown and his "filthy, lying set of pimps" persisted in swearing that innocent men were selling whiskey. Clifford insisted that every one of the "pimps" was a drunkard and easily exploited. This time, several other prominent men traveled to Washington, D.C. to report the graft to the Department of Justice. ${ }^{44}$

In June, Clifford reported that after "riding as an American in West Virginia," he "had a taste of the stinking old rotten crow" on a trip to Harrisonburg, Virginia. At the Virginia line a conductor he knew apologized, but asked him to please move into the rear car due to Virginia law. The following day, when Clifford lined up with whites at the train station In Harrisonburg to get a ticket home, an uneasy black man approached him and told him that he could not get a ticket at that window. The man sent Clifford into the other side of the building, into a room for "blacks only" where he paid his fare, but did not receive a ticket. After refusing to accept de facto segregation in West Virginia where there were no segregation laws, the idea being forced into segregated railroad cars in Virginia infuriated him. Not only was Clifford Jim Crowed, he had to ride in a car crowded with white railroad workers who engaged in "loud and boisterous talking," cursed, and boxed each other without complaint. One of the workers even had the audacity to sit on the arm of his seat. An assault on his concept of both race and class, he called it "Infernal!" and "terrible," and claimed the white railroad laborers made his "pig pen" even more offensive than usual. ${ }^{45}$

The rapid deterioration of race relations in the last decade, the continuous rise of peonage, Jim Crow, disfranchisement, and horrific violence against African Americans through lynching, shooting, burning and mutilation, both frustrated and angered Clifford. Having little sympathy

\footnotetext{
${ }^{44}$ Pioneer Press, May 17, 1913.
} 
for those who tolerated the injustice against black citizens whether it was black Republicans seeking political patronage, Booker T. Washington and his supporters who traded social and political equality for the myth of economic security, or the "bolters" of the National Independent Republican League who erred in their support of democrat Woodrow Wilson, Clifford often issued sharp criticism. For those of the "lower class" who willingly accepted infringements on their rights for money, whiskey, or due to "ignorance," Clifford also had harsh words. When a "certain class of Negroes of Bluefield" asked for Jim Crow saloons, he claimed "to be put back in slavery would not be too severe a hardship. ${ }^{46}$ Although Clifford advocated protest and agitation in the fight against racial discrimination and opposed America's involvement in the war he could see coming, he recognized early on that African American participation in a war could alter race relations in the United States. He stated:

Brutally as the Negro has and is being treated all over this country—jimcrowed, lynched, segregated, shot and burned, no other class has been kinder to his foes, and loved a country dearer than they love this one. In every war they have been patriots, and patriots again, notwithstanding the treatment above referred to, they will be again. Stand up like men, and after the war that is right on us, there will no longer be colored regiments officered by white men,--a relic of slavery. ${ }^{47}$

As segregation became firmly entrenched in American society, Clifford actually made more statements against Booker T. Washington and his policy of accommodation than he did as a member of the Niagara Movement. In 1890, Clifford was supportive of Washington after reading an article Washington wrote in the Plaindealer. Clifford wrote to Washington, stating, "I feel it my duty, though some distance from you, to step under, \& assist in holding up your hands, in defense of right" and that he was "itchingly waiting to espouse every thing you may say on the

\footnotetext{
${ }^{45}$ Pioneer Press, May 17, 1913.

${ }^{46}$ Pioneer Press, July 26, 1913.

${ }^{47}$ Pioneer Press, July 26, 1913.
} 
same line of thought." ${ }^{\text {48 }}$ Clifford's opinion of Washington quickly changed, particularly after the address Washington delivered at the Atlanta Exposition in 1895, and deteriorated as Washington bartered away black rights to fund Tuskegee and attempted to control the African American press through subsidies and patronage; nor did Washington's handling of the Ulrich affair improve that opinion. By 1913, most African Americans, including Washington, knew his attempt to appeal to "the better class of whites in the South" was a failure. ${ }^{49}$

In July of 1913, Booker T. Washington sent a letter to C.H. James of Charleston, West Virginia, informing him that Ralph Tyler, the National Organizer of Local Negro Business Leagues, was coming to Charleston and asking James, head of the local business league, to hold a large reception and give Tyler money for the national league. James replied that he was too busy and added that he did not believe Tyler should come to the city "and pull off a banquet at the expense of the poor" and lead them to believe they should start at the top instead of the bottom— which was poor business. Clifford agreed, saying that James was one of the best business men in the state and that having risen from the bottom to the top was one of the best men to advise others, and adding that it was a "pity as much cannot be said of Booker T. Washington.” Having “met Booker T. Washington’s self-praising body years ago,” Clifford was curious to see if Washington and his business league had made any changes for the better so, while visiting Philadelphia in August, he attended a meeting of the National Negro Business League at the Music Fund Hall. Clifford declared it was not only worse than ever, but that it was "absurd for men to come from all sections of the South on jimcrow cars or chartered ones to prevent it, and from sections where they are disfranchised, lynched and shot down like dogs, and hold up that section for praise.” Astonished at the number of blacks who continued to support Washington,

\footnotetext{
${ }^{48}$ Letter from J.R. Clifford to Booker T. Washington, November 30, 1890, Booker T. Washington Papers Vol. 3
} 
Clifford wrote, "It is not only a great pity, but a crime that will be exposed in time, and that is, the poor deluded Negroes advocate Booker T. Washington as their guide. ${ }^{50}$

Disappointment and dismay confronted the men who marched out of the National Independent Political League meeting the previous year. Wilson's progressive reforms had little impact on African Americans who were unaffected by tariff and banking reforms and few benefits from the labor exemption provisions of the Clayton Antitrust Act due to their exclusion from labor unions. In addition, a record number of bills proposing discriminatory legislation against blacks were brought before Congress including bills calling for the exclusion of African Americans from Army and Navy commissions, the exclusion of African immigrants, the racial segregation of federal workers, and a segregation of the races on public transportation in Washington, D.C. Although none of the bills passed, there were some departments in the federal government segregated or excluded blacks, leading to a decline in the number of African American males working in the federal offices. Separate toilets for black and white workers appeared in the Treasury and Post Office Departments. ${ }^{51}$

Clifford received great pleasure from learning that Rev. J.M. Waldron abandoned what Clifford referred to as the "bogus" group that stole the minutes and operated under the stolen title of the official "National Independent Political League.” Clifford, who was still president of the majority group, reported, “They were like dogs in a manger with us, and they have been fussing among themselves ever since. We shed no tears at their departure, for it was a riddance of bad rubbage.” Despite the bitter split, Wilson's actions toward African Americans led William

\footnotetext{
(1889-1895), 107.

${ }^{49}$ Lewis, W.E.B. Du Bois, 433-434, 466.

50 “Booker’s Cunning Exposed,” Pioneer Press, July 19, 1913; Pioneer Press, August 30, 1913; Pioneer Press, October 4, 1913.

${ }^{51}$ John Hope Franklin and Alfred A. Moss, Jr., eds., From Slavery to Freedom: A History of African Americans (New York: McGraw Hill, Inc., 1994), 324; Kendrick A. Clements, Woodrow Wilson: World Statesman (Boston:
} 
Monroe Trotter, along with Oswald Garrison Villard, to implore Clifford to appeal to President Wilson for the fair treatment of blacks. Clifford asked, "If sense is sense and logic, logic,” should it not be "we who are suffering” appealing to those who supported Wilson? Especially after Villard, Du Bois, Story, and the "traitor Trotter” denied everything Clifford said would happen following Wilson’s election? Clifford claimed those men placed more importance on the Brownsville affair than "the greater evils of peonage, lynching, and disfranchisement." ${ }^{2}$ He claimed the reason the "mouthy sore-head late Negro democrats" had no influence with Wilson was because "they took thousands of dollars for cheap talk they gave to Negroes." Clifford visited Washington and called on "a certain power in authority" as the President of the National Independent Political League. He was told that no direct promises were made to the African Americans who supported Wilson in the 1912 campaign and that Negro Democrats asked for seventy-five thousand for the work they did for the Democratic Party and, therefore, they had no moral claim on the Democrats for the treatment of African Americans. The willingness of a few African Americans to trade their principles for money left the race with little influence in political circles. As a result, Clifford insisted the only thing that could halt the brutality against African Americans was a solid Negro ballot. He wrote:

Ten million of American citizens-people who have bravely fought in all this country's wars, and by their unceasing toll beautified and enriched this land for centuries and cared for their masters' women and children while they were fighting to keep them in slavery, are not only disfranchised, jimcrowed and brutalized, but tens of thousands have been lynched, shot down like dogs, burned at the stake and driven from their homes. ${ }^{53}$

The fight against injustice required a unified voice.

Trotter’s rival “National Independent League” held a meeting that September in Boston,

G.K. Hall \& Co., 1987), 98.

${ }^{52}$ Pioneer Press, September 6, 1913.

${ }^{53}$ Ibid; Pioneer Press, November 1, 1913. 
Massachusetts. Many of the men elected as vice-presidents were not present. Neither Walters nor Du Bois appeared, although Trotter listed Du Bois as a speaker. Archibald Grimke did return to the group, despite the fact that Clifford had to force Trotter to let him in the first time. Clifford reported that Trotter with his "bogus and fake” organization did not, could not, and would not represent the National Independent Political League that he had kept clean under his administration. ${ }^{54}$

In November 1913, William Monroe Trotter visited President Wilson at the White House to confront the administration's policies toward African Americans. Trotter pointed out the injustice and inequality of segregation placed on black Americans and pleaded with Wilson to intervene in the federal departments adopting Jim Crow practices. Although Wilson denied there was any policy aimed at discriminating against blacks in his administration in an attempt to placate the Boston editor, Trotter continued to question Wilson's statements. The meeting ended with Wilson assuring Trotter that the administration would work on the problem.

Clifford was eager to point out the hypocrisy of Trotter’s meeting with Woodrow Wilson to condemn the president's conduct when Trotter's own conduct was questionable; after all, Trotter and four others walked out of the N.I.P.L. meeting and divided the organization simply because the vast majority of the legally elected members refused to endorse the Democratic Party as Trotter desired. ${ }^{55}$ W.E.B. Du Bois printed nothing about Trotter’s visit to President Wilson in the Crisis, an omission that Trotter found "grossly insulting" according to Clifford. He also claimed that any coverage of Trotter's visit in the Pioneer Press would have to be in the language of Lincoln—-about fooling all the people some of the time, but not fooling all the people all the time” for "never did a bigger fakir, or humbug call on a President of the United States.” Angered

\footnotetext{
${ }^{54}$ Pioneer Press, September 27, 1913; Pioneer Press, November 1, 1913.
} 
that Trotter used the title "President of the National Independent Political League” to gain access to Wilson, Clifford claimed he had no right to visit Wilson using that title. ${ }^{56}$ Clifford insisted that everyone who dealt with him knew that his interest in any cause was "bounded by his own selfishness and whims" and his only stand of conduct was "the gratification of an inordinate vanity." Therefore, he argued with everyone he worked with, and when the majority disagreed with him as they did in the Niagara Movement and the National Independent Political League, he walked out. Clifford declared that "as a secessionist, he has Jeff Davis beaten to a razzle.”57

At the end of December 1913, the American Negro Academy held their seventeenth annual meeting. Archibald Grimke, president of the Academy, delivered an address that Clifford called a “masterly oration.” Despite Grimke’s return to Trotter’s “bogus” organization, Clifford had no harsh words for Grimke. Not only did he refer to him as a “profound thinker and a sublime orator,” Clifford also reported that Grimke refuted every derogatory characteristic that men such as Dixon, Vardaman, Tillman, or Blease attributed to African Americans. ${ }^{58}$

Early in 1914, Republicans began calling for an amalgamation of the Republican and Progressive Parties in West Virginia. Black Republicans pushed for cohesion within the black community as well. The McDowell Times, a black newspaper of Keystone, West Virginia, and W.W. Sanders, the State Librarian, remained loyal to the Republican "bosses" in the prior election and continued to do so. Sanders insisted that the Progressives' attempt to maintain a separate organization in the state was robbing them of their influence. After all, the Progressives supported Republicans on the ballot on the grounds that the men nominated were Progressives and adhered to the Progressive platform; so why agitate for separation now? Sanders accused the

\footnotetext{
${ }^{55}$ Pioneer Press, November 1, 1913.

${ }^{56}$ Pioneer Press, January 10, 1914.

${ }^{57}$ Pioneer Press, January 10, 1914.

${ }^{58}$ Pioneer Press, January 10, 1914.
} 
Chairman of the Progressive State Committee of being more in sympathy with Democratic principles than progressive ideology and, therefore, any black voter who wished "to serve the cause of real progress” would not allow himself to be used to advance Democratic policies designed to deprive him of his rights and privileges..$^{59}$

Clifford claimed that while the principles of the Republican Party may be next to God's, Progressives were "sick and tired of sycophants using them to abuse them" and that honest Progressives represented the best of Lincoln and Grant republicanism, which held "the rights of humanity above all others.” Calling Roosevelt his standard bearer, he made it clear he had no intention of compromising with any other party; for while the Democratic party was "steeped and dyed in political sins,” the Republican Party was "not one whit better, for both are rotten, and neither seems to have enough sense to know that they are dead and where they died." ${ }^{\circ 0}$ Adamant in his position, Clifford wrote:

Let it be understood henceforth and forever, that the editor of this paper is unalterably opposed to going back to the old dead party that called the Negroes brothers on the battlefields and nigger after the war. The rascals who turned them over to the master class when biting their lips in anger because of their defeat, ignoring the fundamental amendments to the constitution, put there by men like Lincoln, Sumner, Grant and others, and have used us only as mudsills to step into positions. Go back to the fellows who ride the lowest, blackest scamps in buggies, autos, \& c. to the polls on election days, and refuse the refined class from decent cars, restaurants, moving picture shows, \&c. No Clifford is a Progressive, and by God's help will die one in politics and religion. ${ }^{61}$

On March 16 and 17, T. Edward Hill of the McDowell Times met with J.R. Clifford in Martinsburg to discuss what role African Americans should take in the fall election and the impact the election could have on the black community. After their conference, Clifford and Hill traveled to Parkersburg to confer with black leaders and members of both the Republican and Progressive state committees at the Chancellor Hotel. Labeled as a 'Get-Together Meeting,' the

${ }^{59}$ McDowell Times, October 3, 1913. 
Republicans dominated the meeting. The Republican state Committee men included E. Howard Harper, Keystone; M.T. Whittico and T. Edward Hill, publishers of the McDowell Times in Keystone; W.W. Sanders, State Librarian, Charleston; Joseph Campbell, Moundsville; William Carpenter, Parkersburg; Rev. J.T. Gibbons, William Brown, J.R. Jenkins, and Dr. C.C. Barnett, all from Huntington, West Virginia. Members of the Progressive state committee were J.R. Clifford, editor of the Pioneer Press, Martinsburg; Professor J. Rupert Jefferson, Parkersburg; Attorney S. R. Moon, Wilcoe; and attorney Sweeny, Fayetteville. To win Clifford over, the McDowell Times was now referring to Clifford as that "fearless and matchless editor."62

Discussion at the meeting centered on how to protect the interests of the 64,000 African Americans living in the state. Noting the campaign as one "fraught with serious consequences to the Negro,” the men concluded that African Americans held the balance of power in fourteen counties. In four counties, with the white vote divided between Democrats, Republicans, and Progressives, it was possible to elect blacks to county offices as well as the state legislature. Although everyone did not agree on a union of the two parties, they did agree to co-operate. Hoping to organize black voters in every county with fifty or more black voters, the men agreed to promote unity through the press and from the pulpit. ${ }^{63}$ At the end of the meeting, the black committeemen issued the following statement:

The Negro race in the state of West Virginia views with special concern the attitude of the Republican and Progressive parties toward the present political conditions exist in the state at this time, because of the fact in the breach existing between these two parties we who represent more than 25,000 voters who have always been loyal to the leaders of both parties, have at stake all that is dear to us as men in a free government. From the day that this state became one of the states representing this government, you have impressed upon us that you were in favor of us maintaining our political rights guaranteed to us by the

\footnotetext{
${ }^{60}$ Pioneer Press, January 24, 1914; Pioneer Press, January 12, 1914,; McDowell Times, March 6, 1914.

${ }^{61}$ Pioneer Press, March 7, 1914.

62 “Conference of Leaders,” McDowell Times, March 29, 1914; “Negroes in Conference: Unanimous for Protection of Race-Largely Attended,” McDowell Times, March 27, 1914; McDowell Times, March 27, 1914.

63 “Conference of Leaders;” “Negroes in Conference: Unanimous for Protection of Race-Largely Attended.”
} 
constitution of this state and the Unites States; you have unitedly fought against the Democratic party wherever they attempted to deprive us of any of the rights that we now enjoy. The policy of the Democratic party of this state, as expressed in party platform towards questions affecting our race has not been changed, and we have no reason to believe that its policy will be changed if they are permitted, through this division, to gain control of the legislature of our state. But, on the contrary, we are convinced that in the event they shall be successful at the polls in November of this year, not only will unAmerican laws be placed upon the statute books, but they will make it impossible for either the Progressive or Republican party to get control of the state for years to come. Therefore, we appeal to both Republicans and Progressives to so co-operate in the campaign of 1914 as to thwart the scheme of the Democratic party and to continue the policies which are of mutual concern to us all.

S.B. Moon, W.H. Brown, M.T. Whittico, T. Edward Hill, J.T. Gibbons, T.R. Jenkins, William W. Sanders ${ }^{64}$

Although Clifford did sign the statement at the "Get-Together-Meeting," he was not pleased with the state Progressive leadership. R.S. Bouic, who assumed leadership of the West Virginia Progressives, met with Clifford earlier in the year to discuss a lecture to be held at Thornwood Hall. Bouic informed Clifford that the hall could hold three to four hundred blacks in the gallery, but Clifford said "no" it would not. Bouic then gave Clifford an ad to place in the Pioneer Press for the State Progressive Convention and agreed to pay five dollars for its publication; Bouic never paid him. At the end of March, state Progressives gathered in Huntington for the state convention. Senator Moses Clapp was to speak to the group at the Fredrick Hotel after delegates attended a "dollar dinner." Clifford sent in his dollar to attend the dinner and was eager to hear his friend Clapp speak. Upon his arrival, Clifford spoke to the chairman and a few of the other white party leaders who informed him that blacks could not attend the dinner, nor could they hear Senator Clapp’s speech.. The McDowell Times reported the meeting as "lily white" from start to finish, and that if blacks needed any other proof that the Progressives only wanted to use blacks to aid the Democratic party their "skin is as thick as that

\footnotetext{
64 “Conference of Leaders;” "Negroes in Conference: Unanimous for Protection of Race—Largely Attended.”
} 
of an elephant.” In the Pioneer Press, Clifford stated that he expected to be treated as he was in Chicago the previous year; instead, state party leaders denied him participation in the dollar dinner and told him it would cost his life to hear Clapp speak. ${ }^{65}$ Still, as Clifford reported in the Pioneer Press, his goal was to use political parties as a tool to break down race hatred. Therefore, he intended to remain a true Progressive and active Roosevelt supporter, without following the "local faction of the bread and butter brigade, who boldly deny us our manhood rights."66

However, Clifford's disillusionment with state Progressive leaders was no greater than T. Edward Hill and Matthew Whittico’s growing disappointment with the Republican leaders to whom they gave their loyalty, a sentiment that Clifford experienced in the 1880s. The McDowell Times chastised state Republicans, black and white, for their broken promises, reporting "Pats upon the shoulders, hypocritical smiles, those deceptive hand shakes and that self complacent air of-“I am a Republican —-my father was a Republican,” are not enough today to satisfy the Negro.” Claiming the Republican Party needed African Americans in the state as badly as blacks needed it; the editors warned that black West Virginians were growing weary of "promises without fulfillment, broken faith and absolute silence.”67

Although the black vote in West Virginia more than doubled between 1908 and 1914, with 99 per cent of that vote providing Republican majorities in their respective counties, blacks received no additional patronage or representation in state government. To show the party’s support for its black contingent, the McDowell Times asked the state Republican Party and its candidates for congress to favor the reduction of southern representatives in congress and the electoral college as punishment for their adoption of Jim Crow and disfranchisement laws. ${ }^{68}$ As a

\footnotetext{
${ }^{65}$ McDowell Times, March 27, 1914; Pioneesr Press, September 15, 1914; Pioneer Press, October $24,1914$.

${ }^{66}$ Pioneer Press, September 5, 1914.

${ }^{67}$ McDowell Times, April 24, 1914; McDowell Times, May 8, 1914.

${ }^{68}$ McDowell Times, April 24, 1914; McDowell Times, May 8, 1914.
} 
result, the McDowell Times began to resemble the Pioneer Press, stressing independence and suggesting that blacks initiate a separate caucus to act in the interest of the race in West Virginia and in the nation. Echoing the statements Clifford made in the Pioneer Press for over thirty years, the editors of the McDowell Times wrote, "If the Republican Party cannot live by adhering to its fundamental principles and treating all with fairness and equality it deserves to die. We say this and we have always been and still are Republicans_- "Stand pat where the Negro is concerned. ${ }^{\prime 69}$ The meeting between Clifford and Hill, intended to persuade Clifford and other black Progressive leaders to unite with black Republicans, was unsuccessful in that Clifford remained a Progressive. However, this "meeting of the minds" clearly brought unexpected results as well as intriguing possibilities for the future.

Discrimination at home and America's involvement in foreign affairs dominated the pages of the Pioneer Press in the spring and summer of 1914 and Clifford was quick to link America's racial ideology to its foreign policy. In Mexico, Wilson refused to recognize the leadership of General Victoriano Huerta, who obtained office through a violent overthrow of the popular Mexican leader Francisco Madero. Instead, Wilson sympathized with an armed faction called the Constitutionalists led by Venustiana Carranza. Early in 1914, Wilson lifted an embargo against selling arms to Mexico, enabling America to supply arms to Carranza. Another opportunity to aid Carranza emerged in April when Mexican officials arrested several American sailors on shore leave in Tampico, Mexico. Huerta swiftly released the sailors, but Wilson used Huerta's refusal to issue an apology for the incident along with his failure to salute the American flag on Mexico soil as an excuse to send troops into the Mexican seaport of Veracruz. Unwilling to engage in war, the United States accepted an offer from the South American countries of Argentina, Brazil,

69 “Negroes Should Act Together,” McDowell Times, May 15, 1914. 
and Chili to mediate the dispute. However, Huerta rejected a plan calling for his removal and the establishment of a provisional government. Clifford disagreed with Wilson's attempts to remove Huerta, stating that America "ought to be the last country on this green earth to find fault with Huerta’s election.” After all, it was absurd for the American government to say that it would not stand for Huerta's election on the basis of few votes when Congress was full of senators and congressmen elected through "disfranchisement and ballot robbery."70 Carranza, who managed to overthrow Huerta in August, quickly denounced Wilson for intervention in Mexican affairs as well.

Conflict in Europe quickly overshadowed Mexico’s instability and revolutionary politics. Rising nationalism, colonial expansion, the acquisition of arms, and the European system of alliances combined to create a clash among European nations that would lead to global confrontation. That summer, a Serbian nationalist assassinated Archiduke Franz Ferdinand and his wife in Sarajevo in Austria-Hungary, igniting a war between allies of the Triple Alliance or Central Powers made up of Germany, Austria-Hungary, and Italy and Triple Entente or Allied Powers of France, Great Britain, and Russia in August of 1914. In the Pioneer Press, Clifford wrote that preparations for the war in Europe began a half a century earlier and that while the assassination of the Serbian King and Queen triggered the war, the real cause was human hatred. Sadly, Clifford reported that "it will take millions of dead and indecently buried men to make this hard hearted world think soberly over this exploited war.",71

Clifford, citing George Washington and James Monroe who "gave this country Godly counsel," advised Americans to "keep out of war, work our own soil and keep our own gold.” America's foreign debt and the need for money abroad could lead to serious entanglements and

\footnotetext{
${ }^{70}$ Pioneer Press, July 11, 1914.
} 
debts Americans were unwilling to pay. When President Wilson suggested that October fourth be set aside as a day of prayer for peace in Europe, Clifford claimed that God must have "shut his eyes and frowned," and asked, "Why not pray for the rights of humanity and peace at home where the blackest crimes on God's green earth obtain ${ }^{72}$

Failing to understand why Wilson was taxing Americans for war when the nation was at peace, Clifford urged Wilson, along with congressmen, to set an example and provide half of their yearly salary to the national treasury. ${ }^{73}$ Although Clifford believed Americans had no business paying for a war in Europe, it was the human cost that concerned him the most. He wrote, "For any one to get a proper conception of the bloodiest battle of all time in progress for the past four days and still going on, just think of three times as many men armed and fighting in France, as there are men, women and children in West Virginia. Truly 'war is hell.,”,74

Throughout the fall and winter of 1914, Clifford used Wilson's statements on the war abroad to illustrate the conditions of African Americans at home. After President Wilson set aside a day of prayer calling for an end to European warfare, Clifford insisted Wilson’s next action should be "for him to set apart a day of prayer that Southern white American heathens will stop killing American citizens whose only crime consists in being born black.” After all, why was Wilson so concerned about the killing of Europeans, but did nothing to halt the lynching of innocent African-American citizens in the South? Warning that the country was making "a fatal mistake in its devilish treatment to Negroes,” for although a near-sighted fellow might see nothing to indicate America's involvement in the war, he saw nothing that could prevent it. Clifford noted: “Come when it may, before it ends, there is not a white man, rich or poor, high

\footnotetext{
${ }^{71}$ Pioneer Press, August 21, 1914.

${ }^{72}$ Pioneer Press, September 12, 1914.

${ }^{73}$ Pioneer Press, September 12, 1914.

${ }^{74}$ Pioneer Press, September 12, 1914.
} 
or low who will not be glad to sleep, eat and embrace the humblest negro patriot—and patriots they always have and always will be.” Clifford maintained blacks would remain loyal patriots, although "they may, and should, hate every white man who professes Jesus Christ and treats them like dogs," and deprives them of "all respectable rights. ${ }^{75}$

As war in Europe continued on with little advantage to neither the Allies or Germany, Clifford reported the "ruin and sorrow left in the wake of the warring factions is awful to contemplate, but it all goes on in the name of what they call 'justice.” For Clifford, the "justice” meted out in Europe reminded him of same kind of "justice" given to African Americans in the American South. Despite Wilson's promise to show a Christian attitude toward African Americans if elected, Clifford declared that he had not seen it because "all true Christians believe in the fatherhood of God and the brotherhood of man.” Instead, the chief executive did nothing to stop the "segregation, burning, lynching, jimcrowing and all manner of meanness" practiced against black citizens in the South and, therefore, Wilson's concept of Christianity and his idea of Christianity were absolutely irreconcilable., ${ }^{, 6}$ When the Wheeling Intelligencer suggested that Americans go to church because God spared America from the awful horrors of war, Clifford replied, "Yes, go, and take with you crepe and hang it inside and out of your churches in shame for the wholesale murdering, jimcrowing and disfranchising of inoffensive Negroes for the past fifty years. ${ }^{77}$

Clifford foresaw America's involvement in the war claiming, "Come it must and no earthly power can stop it.” He believed, as did numerous black editors across the nation, that the European war was retribution for Belgium's treatment of blacks in colonial Africa, just as the

\footnotetext{
${ }^{75}$ Pioneer Press, October 3, 1914.

${ }^{76}$ Pioneer Press, October 17, 1914; Pioneer Press, October 24, 1914.

${ }^{77}$ Pioneer Press, November 29, 1914.
} 
institution of slavery led to the American Civil War. Clifford hoped to live without the "curse" of either. An article in the Pioneer Press stated:

Leopold caused as much murdering and suffering in Africa, as Belgium has gotten in return so just is God. Lincoln, the ideal man of the world - the lover and savior of mankind, declared that every drop of blood drawn from the black man's back by the white man's lash had to be taken by the sword, before the war of the rebellion ended, and we believe that drop for drop settled that that terrible debt and Oh! God doth thou know the blood drops of the men, women, and children of your climatic coloring - first in Africa and second in America since 1865? If you reckoned with the master class for the stripes and blood for a of 248 years of slavery, what will be your crushing and terrible finality in pay for the horrors of America's best warriors, best laborers-best in mercy and forgiveness and whose highest ambition is to be the best of men and women? ${ }^{78}$

Clifford prayed, "Let us live forever here without the curse of this terrible war, or the bloody one that freed us and united a once consecrated country."79

The war was not the only thing on Clifford's mind in the fall of 1914. Injustices facing black Americans were a major concern, but he was also angry at Trotter's continued use of the name "National Independent Political League” for his "bogus” organization. In addition, he again found himself weighing the benefits, and drawbacks, of the major political parties. Clifford was sixty-six years old. His children were all grown; the youngest living child, John Jr., was twentyfour and none of the children lived at home. Publication of the Pioneer Press still consumed much of his time, but he continued to maintain an active law practice. Wills and trusts provided a steady income, but he enjoyed the mental sparring and challenge of lawsuits and criminal cases more and often offered to argue discrimination cases for free. Clifford continued to maintain his national ties, but the only organization he remained truly active in was the American Negro Academy. Although Clifford's branch of the National Independent Political League remained in existence, and he remained president, the organization suffered from a lack of funds and,

\footnotetext{
${ }^{78}$ Pioneer Press, December 4, 1914.

${ }^{79}$ Pioneer Press, December 12, 1914.
} 
therefore, the inability to hold a national convention.

As a result, Clifford reveled in the fact that Trotter's friend in the N.I.P.L., Rev. W.D. Johnson, filed a lawsuit against William Monroe Trotter for $\$ 1,500.00$ in wages and commissions. Claiming Trotter "had dunned" persons from the lakes to the gulf and Maine to California, Clifford reported that Trotter knowingly received stolen money and that he held canceled checks that Trotter presented for cash from the N.I.P.L. Clifford insisted that when the N.I.P.L. split in Philadelphia, S.O. Corrothers, a Trotter ally, basically robbed the national committees of their money and that Trotter took it. Trotter then called a meeting of the league to endorse Corrother's stealing and asked members of the League to share the stolen money. Clifford refused. ${ }^{80}$

Declaring it "was conceived in treachery, born diseased and has lived on corruption," Clifford asked every “decent colored American” to denounce Trotter’s group. According to him, Trotter was dangerous because he showed little judgment or self-control and when he failed to rule, he attempted to ruin. Such "spirit" led him to steal the books of the National Independent Political League. Clifford claimed the real N.I.P.L. still lived; Trotter's group could not kill it and, "in due time, our convention will be held, and held for the good of the race and not for political dollars. ${ }^{81}$

Clifford also continued his harsh criticism of Booker T. Washington, arguing that Washington had and continued to do the race ten times more harm than good and "for that reason and that reason alone, the South honors him.” Although he claimed race men must be good enough and broad enough to make use of Washington's words, he berated the Negro Business League as a "hedge fence.” Clifford attended three meetings, where members boasting of wealth

\footnotetext{
${ }^{80}$ Pioneer Press, March 14, 1914.
} 
and influence while African Americans were degraded, lynched, disfranchised and segregated. ${ }^{82}$

Alarmed at increasing racial divisions among federal workers, Clifford labeled it a “nefarious and un-American practice,” insisting segregation had "no place in a Republic.”83 Exactly what was the African American’s “place” in a Republic? What rights and privileges were guaranteed to its citizens? And what people or organization provided the most opportunity for preserving those rights? Clifford knew the answer to the first two questions, but the answer to the third continued to elude him after nearly fifty years. He thought of the Fredrick Douglass quote "The Republican Party is the ship; all else the sea" and pondered the wisdom of what many considered to be a "trite" saying. He also noted that in a time of "startling happenings, thousands who were averse to his sentiments are now seeing things as portrayed by a man who was considered a sage on two continents. ${ }^{84}$ Throughout the years, many men had robbed the Republican Party of its principles for both personal and economic gain, but Clifford believed it was rapidly returning to the principles of Lincoln and Grant. Attributing the turnaround in Republican ideals to Oswald Garrison Villard and the National Association for the Advancement of Colored People, Clifford announced that the Pioneer Press would campaign for the Republican Party. Clifford conceded that not all Democrats were alike, but the majority of those living in the South had and continued to do their best to segregate, Jim Crow, and disfranchise African Americans. He then asked his readers to vote the entire Republican ticket, although he did admit there were a few Democrats who could have his vote anytime. For all intents and purposes, Clifford had gone home. ${ }^{85}$

When President Wilson designated November 26, 1914, as Thanksgiving Day and urged

\footnotetext{
81 “That To Be New York Fiasco,” Pioneer Press, September 5, 1914.

${ }^{82}$ Pioneer Press, October 17, 1914.

${ }^{83}$ Pioneer Press, October 17, 1914.

${ }^{84}$ Pioneer Press, October 24, 1912.
} 
Americans to cease work and give thanks for peace at home, Clifford asked, "How can a true Christian enter in the real spirit of peaceful prayer, when millions of peaceable citizens are disfranchised, jimcrowed, and segregated, and hundreds and thousands have been lynched?” Clifford suggested blacks go to church and pray for the scales of prejudiced to fall from the eyes of millions of whites on that day ${ }^{86}$ Of America's “Christianity” Clifford wrote:

What a blazing shame, nay curse, for a country like this, best situated for health, wealth and climate in the world, and that has used, abused and worn threadbare the Negroes' womanhood and manhood, and now in their unprecedented struggles to regain all that has been lost and go on to perfection, they meet on every hand a dirty slap in the face. On the railroad they - no difference how well educated and refined, are forced into filthy cars, or parts of cars, and tough charged the same and their money taken and placed with the whites, they are not allowed in Virginia and other Southern states to buy tickets from the window that whites do. Here in Martinsburg, a Republican County, they (blacks) can't go to trashy shows unless they go into galleries. Nor can they get a drink of soda water. They make the bread, make up the beds, wash the clothes, the dishes and cook but must only eat in kitchens and when sick and die, they are so hated that they can't be decently buried among the city's dead. God what a shame, and O! God how long? ${ }^{87}$

In nearby Jefferson County, newspaper owner William Campbell attempted to have the Norfolk and Western Railroad Station in Charles Town segregated. Telling him to go ahead and build it because it would never be used, Clifford maintained that unless it was torn down, it could stand as a relic to Campbell's insignificance when he was dead and forgotten.$^{88}$ Clifford, along with other black leaders in the state, had successfully fought efforts to establish Jim Crow cars in the state for over a decade. Still, despite his bravado, Clifford was fearful of the situation. With the chasm between white and black in America at its widest point since the Civil War, for the first time he began to question the nation's acceptance of foreign immigrants into American society while refusing to integrate native born black citizens simply due to the color of their skin. Clifford wrote:

\footnotetext{
${ }^{85}$ Pioneer Press, October 24, 1914.

${ }^{86}$ Pioneer Press, October 31, 1914.

${ }^{87}$ Pioneer Press, December 5, 1914.
} 
What a terrible thing, for a peaceful laboring and country-loving people, whose patriotism has been to this nation gloriously tested in every war, to be denied a man's rights. In come foreigners, who know nothing of our country's laws; speak not a word of our language, yet they can eat in restaurants, ride on first class trains and boats, stop at hotels; in short do what any white man can. ${ }^{89}$

Equally disturbing, immigrants gained acceptance into American society wholly on the issue of race, irregardless of class distinctions, an affront to Clifford who felt it was "quite time that decent and refined colored people, every one of more or less mixed blood, should be accorded the same right." 90

Thirty-six years earlier, only one Jew lived in Martinsburg. Clifford claimed that all of the whites cursed the Jew, calling him a damned Jew, a “Christ Killer,' and a “Sheenie” and forced him to sell his goods from his back, yet the black community welcomed him and, often, fed him. By 1914, Martinsburg had several Jewish families according to Clifford, but whites no longer cursed them; and although blacks spent over 300 years tilling America's land and the Jews came from countries "where dogs are treated better than they were,” they joined the whites in cursing African Americans before they could even speak English. One prosperous Jew, named Hack, owned a restaurant, saloon, and a nickelodium, all of which barred or Jim Crowed blacks, leading Clifford to call any African American who spent his money to enter the segregated nickelodium a “confirmed fool.”,91

Nationally, a determined William Monroe Trotter returned to the White House with another delegation of men from his "bogus" N.I.P.L. to protest the continued segregation of federal workers. Trotter passionately described his displeasure, telling Wilson that African Americans who believed his assurances and supported his election were now being branded as

\footnotetext{
${ }^{88}$ Pioneer Press, June 20, 1914.

${ }^{89}$ Pioneer Press, July 11, 1914.

${ }^{90}$ Pioneer Press, July 11, 1914.

${ }^{91}$ Pioneer Press, February 13, 1914.
} 
traitors to the race in communities and churches across the nation. Trotter's outspoken manner offended President Wilson and after a loud and heated exchange of words, Wilson expelled the delegation from his office. This time, the editor of the Pioneer Press issued no criticism of Trotter or of his use of the title "National Independent Political League. Instead, he wrote:

The Pioneer Press has never surrendered its contention for every right vouched safe by the constitution of this country to the lowest and blackest of God's creation and God forbid it ever should. While there are many things William Monroe Trotter has done out of accord with it, it extends its hand to him and says: "well done good and faithful servant.” Mr. Trotter's words were not insulting. The trouble grew out of the fact, that he pressed the President a little too hard on the raw, and like a sore back horse, he had to squirm. ${ }^{92}$

If Clifford offered a small olive branch to Trotter, he had no compulsion to give one to

Booker T. Washington. In December of 1914, he took a somewhat conciliatory tone on

Washington saying, “It does not add to our strength now to abuse Booker T. Washington or take from his prestige to have our people oppose, but it will pay to unitedly [sic] join in with editors Smith and Mitchell to open the eyes of the world to see him as he is."93 Less than a month later, Clifford berated the Tuskeegan saying, “Our redlight wizard’s praise for President Wilson’s sophistry regarding Negroes is sickening. Absolutely he is the worst foe we have in America.

Ben Tillman and Blease are better friends of ours than he. However, it pleases the rabid, Negro hating Southern editors. Keep on Booker and Robert Burns’ epitaph to the traveler will be yours."94

The new year began with a proposal from the editors of the McDowell Times to organize

\footnotetext{
${ }^{92}$ Pioneer Press, December 5, 1914. Trotter’s group tried several names after splitting from the N.I.P.L., but returned to the title of "National Independent Political League.” The group later became the National Equal Rights League (N.E.R.L.).

${ }^{93}$ Pioneer Press, December 12, 1914. Clifford is referring to editors Harry C. Smith of the Cleveland Gazette and John Mitchell, Jr. of the Richmond Planet.

${ }^{94}$ Pioneer Press , January 9, 1915. In calling Washington the "red-light wizard” Clifford was referring to Ulrich attack on Washington in a red light district of New York where Washington had apparently gone to meet a white woman.
} 
black West Virginians from across the state on behalf of manhood rights. Clifford enthusiastically endorsed the Whittico and Hill's proposition in the Pioneer Press "for he who would be free must himself strike the blow" and "rights denied should meet resistance." ${ }^{95} \mathrm{He}$ also endorsed a bill in the state legislature that disfranchised anyone who sold their vote and anyone who bought a vote for a probationary period of five years. Clifford viewed the ballot as a sacred item and anyone who abused it, did not deserve it. ${ }^{96}$

In March of 1915, W.W. Sanders, former State Librarian and the newly appointed Supervisor of Negro Schools in West Virginia, arrived in Martinsburg. Clifford got out of his sickbed to meet Sanders at the train station only to discover that Sanders rode on a segregated car from the Shenandoah Junction to Shepherdstown. Clifford knew the Norfolk and Western Railroad, despite the absence of Jim Crow laws in the state, segregated its railroad cars between those two points as well as the waiting room in the train station at Shepherdstown. Clifford simply refused to ride it. Despite his age, when Clifford had cases to argue in the courthouse at Charles Town, he rode the B \& O Railroad to Shepherdstown and then walked the last five miles to Charles Town rather than ride on a segregated car. It appalled Clifford that a man of Sanders educational and economic status was too "timid" to refuse to go into "that nigger waiting room" or to ride a segregated car. Clifford claimed Sanders should have ridden in the car for whites or brought suit against the Norfolk and Western, and if every other black would do the same, it would put an end to it. He added, "To think of a man who bared his breast on the battlefields during the sixties to save this union and free the slaves, not being allowed to stop at hotels, or eat in restaurants, because and only because God's climate laws darkened his skin.” Conditions were no better after he arrived, Clifford had to take Sanders to five places before he could find him a

${ }^{95}$ Pioneer Press, January 9, 1915. 
place to sleep and eat. Clifford claimed it was “a curse on Christianity that ought to be blotted out forever."97

Clifford maintained that many blacks would fight that kind of injustice in courts, but were afraid to initiate action because they were poor. In his columns, he assured his readers they had the right to not only file a suit on a pauper's oath, but to carry that lawsuit to the highest court in the land without paying a penny. In addition, Clifford volunteered to take all such cases and to carry them from court to court on a pro bono basis. Therefore, he urged his readers, "get busy and bristle up against every wrong imposed on you."98

It sometimes amazed Clifford that African Americans continued to make progress in what he called a "caste cursed country." He claimed it was a land where men could swear innocent men’s liberties away with impunity, politicians were free to lie and deceive the voters . . . and free to legislate against them once elected; it was also a land marked with prejudice, "the meanest thing on God’s green earth.”99 As for America’s self-styled race leaders, he claimed they received far too much attention, were about as necessary as a politician, and as "helpful as the tramps who are fed by the public.” Clifford, who opposed most of the self-styled leaders’ opinions about what the race should do, insisted everyone should think for themselves and guide themselves accordingly and that the race would be "a thousand times better off” if it had no such leaders. $^{100}$

His opinion of West Virginia appeared more optimistic at first. He wrote that "the man who classes West Virginia among the southern states misses it. Its staying in the Union, its progressive prosperity, thrifty and frugal denizens, its wonderful natural resources have long ago

\footnotetext{
${ }^{96}$ Pioneer Press, February 6, 1915.

${ }^{97}$ Pioneer Press, March 27, 1915.

${ }^{98}$ Pionee Press, April 3, 1915.

${ }^{99}$ Pioneer Press, May 1, 1915; Pioneer Press, May 15, 1915.
} 
ranked it as a northern state,” but considering his experiences and the de facto segregation practiced in the state he added, "Doubtless the wish is father to the thought."101

That May, Clifford informed his readers, "We are forming an equal rights fighting organization in this state.” Determined to wipe off any black laws and make or break parties, Clifford declared this group would not depend on the "campaign thunder of horse and throaty chaps" who were more than willing to "cut the throats of their best friends to please lying politicians.” Clifford, concerned about a Jitney bus line established in Martinsburg that refused to admit African Americans, suggested that blacks bring a lawsuit or start their own line. He also felt confident that if a small group of black West Virginians went to Charleston to meet with members of the Public Service Commission and challenged the Jim Crow practices of the Norfolk and Western Railroad, their segregation practices would cease. Claiming the Pioneer Press was in the fight, he asked his readers to join him in going to Charleston to "lay the infamous matter before the Commission." ${ }^{102}$

In Martinsburg, an African American named William Spears took Clifford up on his suggestion; he put a five-passenger car on the road that admitted blacks and whites. Delighted, Clifford claimed the way to kill prejudice was to flatten out the white man's pocketbook because they would treat you nice simply to fill it back up. At the same time, it furnished transportation for blacks who needed it. "Ride in Billy’s car," urged Clifford, since Spears purchased it for "your manly and womanly pride.” A short time later, Clifford announced there were four buses on the road and that blacks in Martinsburg were keeping them all busy. As a result, white taxis had to solicit black passengers and convey them all over town; a scene Clifford thoroughly

\footnotetext{
100 Pioneer Press, April 17, 1915; Pioneer Press, May 22, 1915.

${ }^{101}$ Pioneer Press, April 17, 1915.

102 Pioneer Press, June 5, 1915; Pioneer Press, July 31,1915; Pioneer Press, May 22, 1915.
} 
enjoyed watching. ${ }^{103}$

At times, Clifford's comments in the Pioneer Press produced positive results, as in the case of the segregated bus line. Unfortunately, just as often, his words led to anger. That May, Clifford printed an editorial in the Pioneer Press stating:

As to the war over the sea, our love is for France and our sympathy for Germany. England is no friend and never has been to America. She tried her best to crush us in our infancy, aided and abetted the destruction of our union and the wickedness of slavery. Germany is square on the rights of men regardless of the color of their skins, and the foremost nation on earth. ${ }^{104}$

The editorial, reprinted in the Wheeling Intelligencer, immediately sparked criticism. A reader from Wheeling reported reading Clifford's comments and asked, if your "sympathy is for Germany and your love for France. In the event of a war with America, would you fight?” Clifford replied that although sixty-eight years of age, he was active, could shoot with accuracy, and certainly would fight for his country with the hope that in doing so, race hatred would be destroyed and blacks would earn full manhood rights. ${ }^{105}$

That summer, Clifford noted that, occasionally, Wilson praised the bravery of black soldiers, but it only occurred because the President could see "war clouds" on the horizon. Clifford claimed that just as George Washington took 3,500 slaves with him to Yorktown to win a victory and then sent them back into slavery, so would Wilson allow blacks who fought in a war to return home only "to be forced to ride in jimcrow cars, lynched, disfranchised, denied school rights and every other right he and his enjoy.” Agreeing that a war “of the blackest type” faced America, Clifford claimed the time to avoid it had passed. Although he found it ironic that African Americans were to fight in a war "to preserve democracy" when they had no democracy at home, he had no doubts about the African American's loyalty to America. Clifford wrote:

\footnotetext{
${ }^{103}$ Pioneer Press, May 22, 1915.
} 
We are in it, and of course every loyal son will stand up or go down with his flag. We were on the fields of battle in the rebellion, are old and gray, but as active, well and game as then, and can march as far and shoot as well as ever, and although treated worse than dogs - can't go to see picture shows, eat in 2x2 restaurants, jimcrowed on cars, send our children to mixed schools, sit on juries and God only knows what not, we shall fight for the country we love and call ours, for God and Time will certainly put us next to Him on the soil we have faithfully and irksomely toiled to cut down its lumber, fence its acres, build its palaces, educate the master class, fight in all the wars, worked long and cared for the white women - wives, mothers, sisters and daughters of those on the field fighting for our retention in slavery-and they in pay even deny us burying space in their gave yards. ${ }^{106}$

Clifford felt that as long as black Americans continued to face discrimination and prejudice at home, black troops did not belong in foreign wars. At the same time, he revealed his hope, and his belief, that blacks' military participation abroad would improve the conditions of blacks at home in the following article:

One thing is certain, if war must be in this country, the aftermath will be in the Negroes' favor. Our faith tiptoes on what can be depended upon and that is, millions of the foreign born who swore their loyalty to the flag will be false, and every Negro, whose path to peaceful labor has been blockaded by these sworn to be citizens will be as loyal to this country and its flag as they have been in peace and in every war this country had had, and that will make them once more tumultuous heroes, and by degrees they'll come into their own. $^{107}$

In August of 1915, Clifford wrote:

We all agree that Booker T. Washington is popular in this country. So has Giles Jackson been, but he is at the end of his race, and Booker isn't far from his. The editor of this paper would rather be right and popular with God than have millions of dollars and be popular with the Negro haters to whom Booker is always playing his discordant fiddle. The music has helped to make hundreds of our people suffer and many others dance or dangle from trees, and now, he is meddling in Haitian affairs. The best thing for the colored people of this country is for America to withdraw her troops and let Booker go over there and settle matters. ${ }^{51}$

After months of discussion on the establishment of a civil rights organization in West

\footnotetext{
${ }^{104}$ Pioneer Press, May 151915.

105 Pioneer Press, June 5, 1915.

${ }^{106}$ Pioneer Press, July 24, 1915; Pioneer Press, July 31, 1915.

${ }^{107}$ Pioneer Press, August 7, 1915.
} 
Virginia, African Americans in the state formed the West Virginia Civic League on August 7, 1915. The group named Dr. F.M. Gamble of Charleston temporary president of the league and agreed to hold their first meeting at the state capitol in September. On September 22, 1915, over seventy of the most prominent African Americans in the state assembled at the Brown Hotel on Capital Street where numerous speakers gave addresses on the civil welfare of black West Virginians. Principle speakers at the meeting included attorney Brown Payne of Raleigh County, Rev. R.B. Bryant of Huntington, and Dr. F.M. Gamble of Charleston. After creating a constitution and by-laws, members of the newly formed organization elected state officials naming Rev. R.B. Bryant (Huntington), President; Brown W. Payne (Raleigh County), VicePresident; E.L. Warton (Mason County), General Secretary; T. Edward Hill (McDowell County), Corresponding Secretary and General Organizer; J.M Ellis (Fayette County), General Attorney and Assistant State Organizer; F.M. Gamble (Charleston), Treasurer; and J.E. Parsons (McDowell County); Dr. C.A. Barrett (Cabell County); Rev. F. Herman Gow (Charleston); Fred Ramer (Berkeley County); William Turner (Ohio County); and M.T. Whittico (McDowell County), Board of Directors. ${ }^{108}$

Created for the welfare and betterment of conditions for black West Virginians, the group maintained there was "No movement in the state so fraught with deep concern to the 75,000 colored people of the state" and that it was not a movement of one man or one group of men, but intended to be an organization "of the people, for the people, by the people.” The West Virginia Civic League had one firmly established principle—justice, "uncompromising justice to all men

\footnotetext{
${ }^{108}$ McDowell Times, September 24, 1915; McDowell Times, September 17, 1915.
} 
alike, under the law”109

With that principle in mind, the goals of the League were to create an effective, lawful organization capable of ensuring fair trials, to address the presentation of the film Birth of a Nation at Bluefield, and to support Board of Director member J.R. Clifford in his fight against the Norfolk and Western Railroad in Shepherdstown and Charles Town. In Jefferson and Berkeley counties, blacks continued to complain about the illegal operation of "Jim Crow" cars on the Norfolk and Western Railroad and the numerous indignities the train crews inflicted upon them when they forced them to ride on the segregated coaches. In addition, the Rev. E.P. Moon of Charles Town accepted Clifford's call to fight against segregation on the Norfolk \&Western’s cars and waiting rooms and according to Clifford, deserved the "thanks of every colored man and woman" in the state. ${ }^{110}$ The group then compiled a list of the needs of the black community, including a tuberculosis sanitarium, better facilities for the reform schools, day schools, protection for black firemen and brakemen, and the protection of black fraternal societies. ${ }^{111}$ These black West Virginians united under the Civil Rights League for the betterment of their race; little did they realize it would become the forerunner to the N.A.A.C.P. in West Virginia. In the months that followed, Clifford continued to work closely with race leaders in southern West Virginia. Still hostile to those black Republicans who craved popularity at the expense of racial progress, Clifford bristled when some of the "race leaders" proposed the establishment of a "Colored Bureau” in West Virginia in 1916. Although willing to compromise with black leaders on what actions should be taken for the benefit of the race, he was unwilling to accommodate whites through self-segregation. Clifford pointed out that while these men were always complaining about the color line, in reality they were the "hatchers, feeders, and leaders of

${ }^{109}$ McDowell Times, October 8, 1915. 
it." He wrote "the Pioneer Press is sick and tired of the little 2x4 peanut politicians who fume and fuss about discrimination” and then head Jim Crow bureaus to corral black voters in election years. He also claimed the very suggestion of a separate or "Colored Bureau” would be an insult to any other race and pleaded, "May the time come swiftly when our men and women will scorn it and the self-assumed leaders."112 Within a year, Clifford was advocating the establishment of local branches of the N.A.A.C.P. and claiming that local branches could actually hold the "balance of power" in several cities. If that was the case, "such outrages as segregation would be an utter impossibility.",113

Throughout 1916 and 1917, deteriorating race relations at home and military engagements abroad continued to overshadow local events in the columns of the Pioneer Press. In 1916 and 1917, there were 50 and 36 lynchings respectively. Of those, perhaps the most brutal was the mutilation, lynching and burning of seventeen-year-old Jesse Washington in Waco, Texas, on May 15, 1916. Horrifically detailed in June and July issues of the Crisis, Washington’s lynching outraged black Americans across the nation. ${ }^{114}$ In Europe, the Allies’ demand for supplies created an economic boom for America that led to a mass migration of African Americans to northern cities in search of jobs. Racial tension coupled with competition for jobs resulted in a race riot the following July in East St. Louis, Illinois. Widespread destruction, arson, shootings, and the lynching of African Americans ensued, leaving more than six thousand homeless and thirty-nine African Americans dead. At the end of the month, eight to ten thousand African Americans marched in a "silent parade" in Manhattan, New York to protest the racial violence. Lynchings, legal injustice, and discrimination in civil service, public schools, trade unions, and

\footnotetext{
${ }^{110}$ McDowell Times, September 17, 1915; Pioneer Press, October 9, 1915.

${ }^{111}$ McDowell Times, September 17, 1915; Pioneer Press, October 9, 1915.

112 Pioneer Press, June 3, 1916; Pioneer Press, August 26, 1916.

113 Pioneer Press, March 31, 1917.
} 
accommodations flourished in America. ${ }^{115}$

Abroad, United States Marines continued to occupy Nicaragua and Haiti after civil war and successive revolutions led to American intervention prior to Wilson's election. In 1916, America deployed additional Marines to the island nation of the Dominican Republic in an effort to dissolve civil strife. In addition to the existing military intervention throughout Latin America, Mexican-American relations continued to decline. After Carranza attained power in Mexico, one of his generals, Pancho Villa, attempted to overthrow his regime. At first, Wilson threw his support to Villa who claimed to represent “the people,” but after Carranza’s forces inflicted several defeats on Villa and his supporters, Wilson claimed neutrality. Early in 1916, Villa, hoping to provoke American intervention, attacked and killed Americans across the border on American soil. His plan succeeded. Wilson, in an attempt to capture Villa, sent a force of nearly 11,000 men under the leadership of General John J. Pershing deep into Mexico where they spent close to a year chasing the elusive Villa without success. Across the Atlantic, Wilson continued to provide loans to the Allies in order to sustain its economic trade. In an effort to stem the flow of supplies, Germany declared a war zone around the British Isles and threatened to sink merchant ships. Since Britain’s ships often resorted to flying neutral flags in order to evade the Germans, all ships flying neutral flags were subject to German intervention. ${ }^{116}$

Despite Wilson's public, but misleading, policy of neutrality on the war in Europe, German U-boats continued to fire on merchant and passenger ships sailing in the declared war zones of the Atlantic. Public outrage over the killing of American citizens led Clifford to ask why Americans were so outraged at Germany’s actions when “hard-headed” Americans chose to

\footnotetext{
${ }^{114}$ Lewis, W.E.B. Du Bois, 514-515.

${ }^{115}$ Lewis, W.E.B. Du Bois, 538-539; "Race Rioters Fire East St. Louis and Shoot or Hang Many Negroes; Dead estimated at from 20 to 76,” New York Times, July 3, 1917.

${ }^{116}$ Lewis, W.E.B. Du Bois, 522.
} 
cross the Atlantic in war zones, yet offered no protest against the daily lynchings going in the South against law-abiding citizens in their own towns? Instead, America continued to "play tag" with Mexico while they "fumbled" in Europe were millions were being murdered. Even worse, he claimed, in the name of "peace and harmony" America went to Haiti, but took warships and shot down poor helpless blacks who were "climbing a more peaceful and bloodless ladder of civilization" than American whites were. In Europe, Belgium "reaped what its wicked old ruler sowed in Africa," as did England. America, due to foreign military intervention, had a "mountain of crimes as high and black for which she must answer." ${ }^{\prime 17}$ In contrast, Germany's power, according to Clifford, came from "a hundred million people educated to love and defend one another with devotion for the flag and land.” In conclusion, he asked, "If fear draws us close together, why not live and act like men and women, growing up together in love, honor, intelligence and loyalty for a flag that knows no race or color and has nothing better for one than the other?” Therein lay America's redemption. ${ }^{118}$

When Wilson ran for a second term of office, Clifford made his position clear to friends and associates in West Virginia and elsewhere. He asked, "Butchered as Negroes have been in the South; jimcrowed and disfranchised by the South; segregated and hated by the South's worst people, and it all, endorsed by Woodrow Wilson's silence and noninterference, how can any living Negro vote to put him back in office? ${ }^{119}$ Indeed, there were no expressions of black support for Wilson in 1916.

Less than six months later, America declared war on Germany and her allies. Despite the nation's recruitment and enlistment of blacks, the Army organized African Americans into segregated units, and the Coast Guard and Marines barred them from service. The majority of

\footnotetext{
${ }^{117}$ Pioneer Press, November 20, 1915.
} 
African Americans went to training centers located in the South, where they often endured humiliating treatment from white officers as well as the surrounding towns that denied them service in restaurants, barber shops, and theaters. More importantly, rumors of African-American “disloyalty” and susceptibility to German propaganda and bribery led to fear and suspicion towards black throughout America. Clifford repudiated such rumors, stating, "Germany and no other foreign foe have the power to bribe a loyal Negro against America.” African Americans were loyal, Clifford claimed, despite racial hatred and a nation that offered them no protection. He wrote, "God for some reason has filled his soul with fighting loyalty for the soil he has made, enriched and stained with his blood, and which in time is sure to be his." ${ }^{\text {120 }}$ Impatient with those who cast doubt on the loyalty of the blacks when their patriotism was strong, Clifford warned Americans those suspicions stemmed from propaganda "designed to detach the American Negro from his country."

Clifford also insisted that unless a miraculous change occurred, the nation was in more danger from race hatred than it was from Germany. He added, "What a shame that the very people who have done so much for America and Americans should be made targets for hemp, fire and shot.”122 Despite his criticisms, Clifford made it very clear he was an American:

This is my country and its flag is also mine. The treatment we get is neither's [sic] fault. This country and its flag are to me, things of beauty and joys forever. We fought for them in the sixties and would do it again, and the time will come when they will be ours to enjoy fully, by courtesy to all—slavery to none. ${ }^{123}$

Unexpectedly, the Pioneer Press stopped publication and closed its door in the fall of 1917. In one of his last statements on the war, Clifford predicted, "Mark our word that the part the

\footnotetext{
${ }^{118}$ Pioneer Press, February 19, 1916; Pioneer Press, October 14, 1916.

${ }^{119}$ Pioneer Press, October 14, 1916.

${ }^{120}$ Pioneer Press, March 31, 1917.

121 "Loyalty of the Colored American,” Pioneer Press, April 14, 1917.

${ }^{122}$ Pioneer Press, September 1, 1917.
} 
American men of all colors_called Negroes—are destined to play in this world-wide war will give brilliancy to history."124

${ }^{123}$ Pioneer Press, June 9, 1917.

${ }^{124}$ Pioneer Press, August 18, 1917. 


\section{CHAPTER SIX}

\section{“A LITTLE BARK ON THE SEA OF JOURNALISM:” Thirty-Six Years of the Pioneer Press}

"To run a country newspaper one would have the constitution of a long eared mule, the nerve of Teddy Roosevelt, the self control of the ancient martyrs, the capacity of a bookkeeper for detail, the ability to "stand off" the bill collector, - a cob pipe, a pair of shears, a paste pot, a high education and a railroad pass."

A few years after J. R. Clifford established the Pioneer Press in 1882, he reported that the "best people of the State" read and appreciated the Pioneer Press and claimed "it is destined to be one of the best papers in the country." Nationally recognized, when the Press closed its doors at the end of 1917, it was also the longest running black newspaper in America. From its conception Clifford promised that in the columns of the Pioneer Press "we shall boldly advocate our thoughts, and never swerve an inch in the full defense of the rights of our race.” It was a promise he kept, despite numerous obstacles, throughout the Press's nearly thirty-six years of publication. During those years, he willingly offered space in his columns to anyone with differing viewpoints or ideas, believing that African Americans should open their minds to different perspectives and then use their minds to think, evaluate, and make informed decisions for the betterment of the race; for only men who consciously believed they were right could boldly advocate and defend those decisions. ${ }^{126}$

A labor of love, Clifford maintained there was no work more pleasant than "steering our little bark on the sea of journalism” and he felt there was no paper in the country better prepared to "stem the storms" and turbulence of the era than the Pioneer Press. Clifford credited its strength to the "brave men" connected with the Press, stating that "when others shall have been

\footnotetext{
${ }^{125}$ Pioneer Press, October 4, 1913.

126 Pioneer Press, October 4, 1913; Pioneer Press, August 1885.
} 
stranded, this one will be sailing into the harbor of manly recognition, where freedom of speech and action are trophies of the highest civilization.” In practical terms, he called it a "readable” paper, owing to contributions from men he labeled as "some of the best writers in the country" as well as his refusal to accept the submission of what he referred to as "trashy matter.”"127

In its early years, the majority of those writers were prominent African Americans from towns across the state of West Virginia. Men who served as Clifford's assistant editors provided regular editorials for the Pioneer Press and included D.T. Williamson of Grant; Rev. G.W. Hollinger of Wheeling; and Professor J.L. Champ of Parkersburg. ${ }^{128}$ In 1886, Rev. E.E. Underwood of Mt. Pleasant, Ohio, and Professor George T. Jones of Weston joined Rev. G.W. Hollinger and Professor J. L. Champ as the assistant editors. ${ }^{129}$ These men wrote editorials on a variety of topics dealing from social concerns such as education and prohibition to political issues facing the black community, including such controversial issues as independent voting and whether or not blacks should remain loyal to the Republican Party. In the fall of 1886, Clifford grasped "the scholarly hand of Professor A.W. Peques of Parkersburg" claiming he intended to hold onto it "with a tenacity of a vice.”" Along with Peques, Clifford tried unsuccessfully to recruit Professor James McHenry Jones of Wheeling to his editorial board. Jones, who Clifford described as making "rhetoric a whirlwind and logic fire," finally agreed to join the editorial board in December, providing the jubilant Clifford with what he deemed “a Christmas gift.”131 Clifford occasionally experienced problems with his editors who, for a variety of reasons,

\footnotetext{
127 “Still They Come,” Pioneer Press, November 1886.

${ }^{128}$ Pioneer Press, August 1885. Williamson and Hollinger became assistant editors sometime in 1885.

129 Pioneer Press, August 1885; Pioneer Press, September 1886.

${ }^{130}$ Pioneer Press, August 1885; Pioneer Press, September 1886; Pioneer Press, October, 1886. Peques soon became a professor at Shaw University in Raleigh, North Carolina, but continued to write articles for the Press. 131 Pioneer Press, August 1885; Pioneer Press, September 1886; Pioneer Press, October, 1886; Pioneer Press, December 1886. Well known throughout West Virginia as an educator and orator, Clifford praised Jones for his scholarship, logical reasoning, and fearless oratory and claimed that proof of Jones' ability lay in the fact that he
} 
sometimes failed to submit their articles on time. He revealed the difficulties of keeping a group of prominent men happy when he wrote, "Now and then our correspondents wish to be in fashion, and go on a strike. Please gentlemen, what's the trouble now?"132 Despite his frustration, the following advertisement, posted in the Pioneer Press in August of 1888, suggests that Clifford maintained a sense of humor over his "missing” editors: "Lost—somewhere between here and Mt. Pleasant Ohio, Edward E. Underwood. Any one finding him and will report the same at this office will be rewarded."

In addition to his co-editors, other prominent African Americans frequently contributed articles to the Pioneer Press. Within the cadre of correspondents was Robert W. Simmons of Parkersburg, the preeminent black leader in West Virginia coming out of the Civil War. Simmons, who Clifford described as “Old Man Eloquent,” often contributed to Parkersburg newspapers using the pseudonym "Rhombus."134 Professor F. Cardoza of Washington, D.C., another prominent member of this group, wrote on topics from education to women's rights. Clifford added women to his group of correspondents in February of 1887 with the establishment of a “Woman’s Column” edited by his sister-in-law, Coralie Franklin. A graduate of Storer College, Clifford respected Franklin’s intelligence and method of elocution, claiming she "puts pathos and perceptible inspiration into the word of God" and there was not one in fifty who could "step upon the same stage and read the same piece to the same audience." Clifford described her as "a farseeing deep and careful thinker, a solver of knotty problems, rich in experience, happy in a debate for right and race uplift."

received $\$ 1,000.00$ a year as principal of the Wheeling schools.

${ }^{132}$ Pioneer Press, December 1886; Pioneer Press, March 1887, 2.

${ }^{133}$ Pioneer Press, August 1888.

${ }^{134}$ Pioneer Press, September 1886.

${ }^{135}$ F. Cardozo, "Woman’s Rights,” Pioneer Press, July 1887; "You Can. Then Why Not Be A Good Reader ?”

Pioneer Press, September 1886; “The Woman's Column,” Pioneer Press, February 1887; Pioneer Press, July 27, 
Although other women, particularly Mrs. J.O. Thompson and Bonnie Tribble, wrote and continued to write "pickings" from towns across the state describing the educational, religious, and social events in their areas, "The Woman's Column" was the first and only editorial column written and edited by women and devoted to women’s issues in the Press. Coralie Franklin solicited articles from educated black women across the state to supplement her own writings. The editorials reveal the expectations and actions of educated black women as well as the values and limitations imposed by nineteenth century society’s Victorian standard of “true womanhood.” In “The Girl Graduate,” Franklin maintained that young, educated women should have a mission and that they should strive to fulfill it. At the same time, it was evident that a woman's primary duty was to her home since other articles dealt with issues such as "Cleanliness is Next to Godliness” and "Books for the Home.” In "Moral Education,” the printed version of a paper Coralie Franklin read at the Women's Valley Camp meeting on July 22, 1888, Franklin wrote that when people began to cry out that it was a mistake to give so much attention to education of the head and not the hand, leaders made "another mistake greater and more fatal in its effect" in turning to industrial education. Franklin, however, was not debating the value of classical education over industrial education; but the necessity of moral education or "education of the heart." ${ }^{136}$ Anna E. Brown made a similar argument in her article titled "True End of Female Education.” She no longer recommended the acquirement of knowledge (that was expected), but the uses of it to build moral character. According to Brown, the true end of female education was to "exalt the moral character" and give a "high and ennobling view of the Creator." women, Mrs. Alice Fountain of Parkersburg, Miss Mary L. Smith, and Annie S.D. Bates, also

\footnotetext{
1914.

136 “Cleanliness is Next to Godliness” Pioneer Press, May 1887; “The Girl Graduate,” Pioneer Press, June 1887; "Books for the Home” Pioneer Press, December 1887.

137 “True End of Female Education,” Pioneer Press, February 1887.
} 
addressed issues such as the role of women in moral uplift and prohibition. In fact, it is Bates article in the Pioneer Press that reveals the first temperance union for African-American women in West Virginia, the Mount Hope Woman’s Christian Temperance Union created in Harpers Ferry in June of $1887 .^{138}$

For the most part, Clifford was progressive in his attitudes toward women although he did accept some of the Victorian notions of womanhood. For example, he was not opposed to women gaining the right to vote and felt that eventually women would obtain the franchise, but he did believe their engagement in politics could threatened their greatest contribution to society-their virtue. He wrote, "Whenever this country grants to women the right to vote, and they accept it, woe be to that in them, which men most admire, and even demons will protect—virtue, the mother of modesty." 139 Yet he firmly believed in education for women as well as their right to fight for the civil and political rights of the race. Clifford wrote that the politically outspoken Ida B. Wells, "while not a voter, is striking sledge-hammer blows on the line of political independence — the right thing for every brainy Negro woman to do.” ${ }^{140}$ Unlike many black men of the era, Clifford was also quick to defend the virtue of black women and to place the responsibility for their negative image squarely on the backs of white men in the pages of the Pioneer Press. Clifford wrote, "Say what you please about our women, they smell as sweet, dress as neat, are as clean, and virtuous as any class of women in America, considering their forbearers

\footnotetext{
138 “The Women’s Column,” Pioneer Press, July 1887. Mrs. Anna S.D. Bates, who documented the creation of the Women's Christian Temperance Union (WCTU) branch at Harpers Ferry, was from New York. According to her report, the Mount Hope WCTU had twenty-five members consisting of nineteen active and six honorary members. Officers included Coralie Franklin, President; Mrs. Rosa S. Arter and Mrs. William H. Bell, Vice-Presidents; Mrs. Laura B. Lightner, Corresponding Secretary; Miss Alice V. Peyton, Recording Secretary; and Miss Florence Lovett, Treasurer.

${ }^{139}$ Pioneer Press, February 29, 1888.

${ }^{140}$ Pioneer Press, May 20, 1911.
} 
were blood stained and back-bruised mistresses of most of their masters old and young." ${ }^{141}$ In another article, he wrote:

The man who says that colored women are devoid of virtue and have no regard for purity of character, is an individual absolutely without any compunction of conscience whatever. Of all the women in the world, no class of them anywhere are more to be commended for their love of chastity than are those of our race. This is true, too, in the face of the all too patent fact that every means known to the wily and unscrupulous libertine who filches the virtue of all the women who succumb to his iniquitous cajolery is used to destroy the priceless heritage of true womanhood. ${ }^{142}$

Clifford's outspokenness along with his criticism of the Republican Party led many of his editors to abandon the Press as northern Republican industrialists strengthened the party within West Virginia and provided patronage positions to those who brought black industrial workers into the fold. Clifford became the sole editor of the Press, except for a few years in the 1890s when the pressures of his legal practice and a lack of funds forced him to name John W. Cromwell of Washington, D.C. as co-proprietor and co-editor of the Pioneer Press. ${ }^{143}$ From the 1890s on, correspondents to the Press were, like Clifford, more radical in their political outlook and of national stature.

The columns of the Pioneer Press frequently carried the articles of well-known journalist John E. Bruce, commonly known as “Bruce Grit.” Bruce’s nationally distributed commentaries addressed the relationship between blacks and whites, including whites’ perception of the socalled “Negro Problem” in America. In an article titled “Anglo-Saxon Arrogance,” Bruce claimed "the Negro problem" existed "because the white man has permitted himself to believe that the Almighty made him of a better kind of dust and injected a better and redder quality of blood into his veins than he did other races despite the declaration 'of one blood created He all nations of men for to dwell upon all the face of the Earth." Accordingly, "these awfully smart

\footnotetext{
${ }^{141}$ Pioneer Press, August 16, 1913.
} 
white men” felt they understood blacks “due to their super abundant ego, their complacent conceit, and faith in their almightiness.” However, Bruce freely criticized black leaders as well. In "Oratorical Geysers," he admonished African American speakers who were "not orators, but flatterers of those in the public eye.”144 Politically, Bruce and Clifford were in agreement; both disliked the policies of Booker T. Washington. Bruce maintained that Washington was "a man of peace, a non-resistant," but that "peace secured at the sacrifice of a right eminent, will not be of long duration.”145 In addition to his national columns that appeared in the Press, Bruce also wrote articles specifically for Clifford and the Pioneer Press. One of these, a fictional story titled "His Double," appeared in the Pioneer Press in September of $1911 .{ }^{146}$ Another article, “Race Prejudice,” led Clifford to chastise W.P. Kemp of the Detroit Leader for inserting the piece in his paper without giving the Pioneer Press proper credit. However, Clifford was good natured about his “mild protest," telling Kemp that if he promised not to do it again, "we will forgive you Brother Kemp, because you are a real good fellow, and are always found on the right side of the firing line.”147

Soliciting good writers was only one part of producing a quality newspaper. After establishing the Press in the offices of Wisner's Martinsburg Independent, Clifford soon constructed an office for the paper next to his home on West Martin Street and purchased his own printing equipment. Clifford did all the work. He set the press and type and did his own printing. Eager to make the monthly paper into a weekly, he knew his correspondents would have to write regularly and more often to fill the pages of the Pioneer Press. Subscription rates started out at

\footnotetext{
142 Pioneer Press, September 25, 1915.

143 Pioneer Press, January 16, 1892.

144 “Anglo-Saxon Arrogance,” and “The Negro and the White Man,” Pioneer Press, March 18, 1911; “Oratorical Geysers,” Pioneer Press, April 1, 1911.

145 “Oratorical Geysers;" “The Negro and the White Man.”

146 “His Double,” Pioneer Press, September 16, 1911.
} 
seventy-five cents a year, forty cents for six months, or twenty cents per three months.

Advertisements sold in advance for seventy-five cents for a "one inch, one time" advertisement or fifty cents for a standing advertisement; failure to pay in advance resulted in the charge of one dollar. In May of 1902, the Pioneer Press displayed a new slogan on the front page:

\section{“HERE THE PRESS, THE PEOPLE’S RIGHTS MAINTAIN, UNAWED BY INFLUENCE, AND UNBRIDGED BY GAIN."}

By 1911, subscription rates were one dollar and fifty cents per year, seventy-five cents for six months, or forty cents for three months. Clifford provided sample copies of the Pioneer Press to potential subscribers and gave reduced rates to organizations. ${ }^{149}$ For those who submitted news or articles to the Pioneer Press, there was one "iron bound" rule: the Pioneer Press absolutely refused to print any and all unsigned correspondence for the "protection of the newspaper man and the writer." ${ }^{150}$

In addition to soliciting writers and advertisers, penning a significant portion of the content himself, setting the type, and printing the newspaper, Clifford also was responsible for the financial success of the Pioneer Press. In order to educate and inform the race, the Press had to survive. For Clifford, that meant spending time and money traveling the state as a publicity agent and salesman, selling subscriptions to both blacks and whites; and when subscriptions went unpaid, he also served as the collection agent. Occasional notices appeared in the Press stating: "Out in the interest of the Pioneer Press, to collect and solicit subscribers. Please be prepared to pay promptly, for I have a large territory to go over, and my time is limited, owing to other pressing matters.”151 Those who read the paper and failed to send payment aggravated Clifford,

\footnotetext{
${ }^{147}$ Pioneer Press, November 28, 1914.

148 Pioneer Press, May 24, 1902.

${ }_{149}$ Pioneer Press, September 6, 1890; Pioneer Press, March 25, 1911.

${ }^{150}$ Pioneer Press, October 24, 1914; Pioneer Press, November 21, 1914.

${ }^{151}$ Pioneer Press, June 21, 1913.
} 
but he claimed "one of the meanest men on earth" was the fellow who subscribed to the Press, took the paper for several years, and then had the postmaster stamp it "refused." Not only did Clifford fail to receive payment, he had to pay postage both ways. ${ }^{152}$

For almost thirty-six years Clifford put his heart as well as his pocketbook into the Pioneer Press, laying his ideas and perceptions, hopes and dreams, and values and principles between pages of frustration, disappointment, indignation, and anger. His words reflect both his beliefs and his time; revealing the impact of race, class, and gender on his perspective of morality, religion, education, and politics. While some of his perceptions may have shifted over time, his purpose did not. More than anything else, the pages of the Pioneer Press expose Clifford's quest for "true" equality ... and his unwavering determination to achieve it.

As expected, the issue of race in dominates the pages of the Pioneer Press. In his many columns Clifford documents the rise of de facto "Jim Crow" segregation in West Virginia, the proliferation of legalized segregation across the South, and his battle against both. In doing so, he depicts an era of hope and expectation, one in which African Americans believed that America would finally adhere to its tenets of equality and Christian brotherhood, only to discover that the idea of America as a bastion of freedom founded on Christian principles was a myth.

In An American Dilemma (1944), Swedish economist Gunnar Myrdal argued that America's conflict over race "is the ever raging conflict between, on the one hand, the valuations preserved on the general plane which we shall call the 'American Creed,' where the American thinks, talks, and acts under the influence of high national and Christian precepts, and on the other hand, the valuations on specific planes of individual and group living, where personal and local interests; economic, social, and sexual jealousies; consideration of community prestige and

${ }^{152}$ Pioneer Press, November 21, 1914. 
conformity; and all sorts of miscellaneous wants, impulses, and habits dominate his outlook.”

Accordingly, Americans faced a moral dilemma between their theoretical concepts of "liberty and justice for all” and religious sanctification and the practical application of those concepts to African Americans. Although progressive Americans, black and white, applauded Myrdal's evaluation of race relations in American for decades after it appeared, African Americans recognized the discrepancies between America‘s democratic ideology and the practice of racial exclusion long before Myrdal’s “groundbreaking” study. ${ }^{153}$

On August 25, 1893, Frederick Douglass stood before a crowded audience during the “Colored People’s Day” at the World's Columbian Exposition to discuss the race problem in America. Aggravated with hecklers, Douglass told the crowd, "There is no Negro problem. The problem is whether American people have loyalty enough, honor enough, patriotism enough, to live up to their own constitution.” Douglass's statement resonates within the pages of the Pioneer Press. Clifford expressed similar sentiments on numerous occasions, although discrimination against African Americans in a nation founded on Christian principles appeared to anger him the most. On one occasion, he wrote, “The 'worst problem' it is claimed that exists in this country is the 'Negro problem.' The only problem relative thereto, is the complications of the golden rule. This problem alone hangs on this simple fact; that the white man lacks enough of the religion of Jesus Christ to treat the black man as a man and brother. That's all."154 He said almost the same words when chastising those who were forever talking about the "Negro problem." Clifford said, “There is none. It’s a white man's problem, and when men will forget the dollars in love and

\footnotetext{
${ }^{153}$ Gunner Myrdal, An American Dilemma: New York: Harper Brothers, 1944, Introduction; For a historiographical analysis on evaluations of Myrdal's study, see David W. Southern, "An American Dilemma After Fifty Years: Putting the Myrdal Study and Black and White Relations in Perspective,” History Teacher Vol. 28 No. 2 (1995): 227-253. Recent historians maintain that America's moral dilemma declined or disappeared in the late 1960s as white Americans felt black Americans were demanding more than racial equality. See Andrew Hacker, Two Nations: Black and White, Separate, Hostile, and Unequal New York: Scribner, 1992.
} 
duty to man and apply the golden rule to all God will be pleased."155

From its beginning, the Pioneer Press sought full and equal rights for African Americans. However, despite his integrated education, Clifford was not an early advocate of mixed schools. Knowing that southern white parents would never allow black teachers to educate their children, Clifford was well aware of the economic impact that integrated schools could have on black teachers. When the Catholic Tribune accused him of being a quarter a century behind the times in July of 1887, Clifford responded that "thousands of people who depended on teaching for a living will not recover in a 'quarter of a century,"” and while “we may be 'behind the times,' we are keeping the dollar ahead of us.”" ${ }^{156}$ Clifford, or course, did change his mind and challenged West Virginia’s segregated school system a mere five years later in Martin v. Board of Education. Years later, he insisted, "Mix the schools, for there is no color in Heaven.”157

Clifford also changed his position on the subject of amalgamation, altering his tone from one of conciliation to one of defiance. In 1887, Clifford claimed that, unlike whites, blacks had no reason to look for mates outside the race:

The fact that this constant change is conductive to health, intelligence and power, is the reason we advocate amalgamation for the race. We are aware that to do it, many claim it will cost bloodshed and that the whites will never submit to it; but that is not so, for we are doing it right in this town and every town in this broad land and we are destined to do it, and the good white people will rejoice in it, and the best white ministers unite us. Oh! Don't boil over for here is the solution-we don't mean to go out of the colored race to do it; for we have all kinds of color to select from, as black as we want, as brown as we want, as white as we want, and best of all, the olive color, the prettiest in the world. So you see, we have the advantage of the whites, for we can get any color we want among ourselves. $^{158}$

However, after years of listening to black men being identified as from a "rape race" and seeing

\footnotetext{
${ }^{154}$ Pioneer Press, January 25, 1910.

155 Pioneer Press, February 28, 1914.

${ }^{156}$ Pioneer Press, July 1887.

${ }^{157}$ Pioneer Press, August 1, 1914.

${ }^{158}$ Pioneer Press, May 1887.
} 
them lynched in defense of the purity of white women, Clifford bluntly wrote:

Why all this twaddle about intermarriage, in the sight and face of its existence and that in slavery for more than 200 years, is for none but fools to explain. If white men preferred black women to their own in slavery, why can't colored men, if white women agree, mate with them in freedom? Millions of Negro men and women, made so white by the master class that they pass for white are married to and living with white men and women, in this and foreign lands. It always has been so, and always will be. No matter how black it is his or her privilege to marry any color wanted, from the blackest to the whitest. Hence why not stop clamoring about intermarriage? It is the South that is constantly hollering thief-when it itself stole the goods. ${ }^{159}$

Clifford also had a change of heart on the issue of migration. In the early years of the

Pioneer Press, he urged blacks to remain in the South. However, eventually he came to believe that there was no hope for African Americans and whites in the South to ever get along and felt blacks should move to where they would be treated "like men and women.” In the midst of the Great Migration (1910-1930), Clifford encouraged African Americans to leave the South.

Recognizing the grievous losses that accompanied migration, the loss of property and home, he insisted "the growth and freedom of manhood, the education of your children, and the sacred right to vote will soon make you so happy, that the greatest regrets you will have will be that you did not leave long, long ago.”160

Although Clifford frequently called for full citizenship rights and complained when those rights were abridged, numerous articles on de facto and de jure "Jim Crow" do not appear until after 1900. Legally, the only laws segregating blacks and whites in the state of West Virginia were in schools and marriage. The state passed no legislation segregating the races in railroad cars, hotels, restaurants, theaters, or "other places of amusement.” As a result, Clifford refused to cooperate with any attempt at segregation. De facto segregation occurred, Clifford maintained, because black West Virginians accepted it and lacked the courage to take a stand against it.

${ }^{159}$ Pioneer Press, June 20, 1914. 
Clifford expressed his viewpoint on the subject freely in the Pioneer Press:

Twenty years ago [1894] this town was, in all public places free to all for their money's worth. Not so today, and why? Because and only because, the colored people encourage all that's inflicted on them. Had they opposed as we did-go in, sit down anywhere and defy them to put us out, there would be no jimcrowism in Martinsburg ... but they have been foolish enough to enforce it in every public place, except 'the common peoples' saloons. Nevertheless and not withstanding, if other sections are only partly filled the jimcrow one is always crowded and more laughter and satisfaction given than by the 'sit where-you please class.' So it is plainly seen they lack self-respect, manhood and womanhood, hence they treat them worse than slaves. ${ }^{161}$

In his remarks on the Martinsburg "Opera House," Clifford frequently linked segregation to uneducated, lower class African Americans:

Opera House" — shanty with galvanized iron—most of the fly by night and many degrading shows come. First-Negroes went as others, paid for their seats and sat where they chose, but of late years, they have been jimcrowed. They took, and seemed so well pleased with it, that they got an extra dose of it, and were not allowed to as much as go into said place through the same door. A 'nigger cutty hole' was made, and they flock in through it, and go up into the gallery with the delight of smiling angels - poor Negroesthe worst foes the race has. ${ }^{162}$

The more they are jim-crowed the better they seem to like it, and our proof is their prolific patronage - for example-Martinsburg has about gone to the last ditch on the jim-crow line, and the Negroes took it so well, that a 'nigger door and gangway' have been made for their ingress. But that is not the worst-upstairs they must go, but up there they are forced to sit over in a separate corner, and believe us, they spend more money and giggle and show their teeth to a greater extent than any other class in Martinsburg. The whole thing - jimcrowism, and its patronage is dirty and low, and the warm place will be full of jimcrow advocates and the cowardly blacks who go to such. ${ }^{163}$

Although the acceptance of Jim Crow practices among lower class blacks promoted its usage, according to Clifford, it was the "better class" of African Americans who suffered from it.

Clifford reported that it was always "the lowest blackest scamp" who rode in buggies or autos of southern whites to the polls on election days, yet those same southern whites refused "the refined

\footnotetext{
160 “Changed His Mind,” Richmond Planet, May 6, 1899; Pioneer Press, December 9, 1916.

${ }^{161}$ Pioneer Press, May 30, 1914.

${ }^{162}$ Pioneer Press, February 11, 1911.

${ }^{163}$ Pioneer Press, August 2, 1913.
} 
class from decent cars, restaurants, moving picture shows. ${ }^{164}$

Clifford never felt that Jim Crow legislation would be enacted in West Virginia, although there were numerous instances where Jim Crow legislation, mostly aimed at railroad cars, was introduced to the legislature. ${ }^{165}$ Clifford felt their were "too many good and liberal minded men in West Virginia” for Jim Crow legislation to pass, including Democrats such as Cleveland Seibert, a legislator from Berkeley County who voted against the segregated cars. ${ }^{166}$ However, he did believe that as segregation spread across the south, "we may expect to hear of many unpleasant, disgraceful and unnecessary happenings.” Clifford called the laws "ridiculous in their make up and drastic in their workings" and insisted they were "plain evidence of the perverted."167

Even more alarming to Clifford was the "drastic workings" and often "perverted” forms of punishment inflicted on African Americans believed guilty of crimes, whether those crimes were real or perceived. As a black man as well as a lawyer, Clifford condemned the violence African Americans frequently encountered, from legalized forms of punishment such as convict leasing and hanging to the extralegal condemnations of mutilation, lynching, and burning. According to Clifford, the establishment of convict leasing systems in the South was "inhuman and villainous legislation.” Calling it a "bestial manner of using criminals,” he felt the practice should be eliminated and a more humane form of punishment be used. ${ }^{168}$ Although innocent African Americans frequently found themselves accused of a variety of crimes, Clifford also recognized

\footnotetext{
164 Pioneer Press, March 7, 1914.

165 “Amendment to Disfranchise the Negroes: Voted Down in the Senate by Strict Party Vote of Twenty-Two to Four,” Charleston Advocate, February 7, 1907; “The Democrats Declare for Jim Crow Cars and Negro

Disfranchisement,” Charleston Advocate, July 31, 1908; “Protest Against the Passage of Jim Crow Law,” Charleston Advocate, December 17, 1908.

${ }^{166}$ Pioneer Press, March 4, 1910.

${ }^{167}$ Pioneer Press, 1911.

${ }^{168}$ Pioneer Press, August 1885.
} 
that at least some of those charged with crimes were guilty. However, he was also aware that it was more likely for an African American to be hanged for murder or rape than a white man. Between October of 1899 and November of 1928, the West Virginia State Penitentiary at Moundsville, West Virginia, hanged fifty-one men; thirty-two of whom were African American. ${ }^{169}$ Clifford did not oppose the punishment of hanging for those guilty of crimes, but he did expect all Americans to be tried and punished equally, regardless of color. Clifford pointed out one of those discrepancies in September of 1914 when Judge J.M. Woods sentenced a rich, white farmer named E. Graham Wilson to fourteen years in the state penitentiary for rape. Clifford wrote that Wilson should consider himself "very fortunate," considering that an African American, George Williams, "was tried in the same county, convicted of the same heinous offense as was Wilson, and sentenced by Judge Faulkner to be hanged by the neck until dead.”170 While Clifford advocated castration for adults convicted of rape (regardless of color), he was against handing down harsh punishments for children convicted of crimes. When a court in South Carolina sentenced an eleven year old girl to be hanged for the poisoning of a white child left in her care, Clifford maintained that he could not "approve of the hanging of mere children" since they were often "ignorant of the enormity of the crime.”"171 He also argued that no boy in his teens should be sent to county and state prisons, where locked up with “earth's hardshells of humanity they graduate in all kinds of language, crime and conduct.” He felt children should be sent to the best homes of reformation the state could afford. ${ }^{172}$

While inequalities in the justice system were a major concern of Clifford's, the escalation

\footnotetext{
169 “Souvenir of the West Virginia Penitentiary,” 1929, as cited on http://www.rootsweb.com/wvmarsha/hangings.txt $>1 / 11 / 06$

${ }^{170}$ Pioneer Press, September 26, 1914.

${ }^{171}$ Richmond Planet, July 30, 1898; “An Infant to be Hanged,” Pioneer Press, July 1887. Clifford and John Mitchell, owner and editor of the Richmond Planet, engaged in a discussion hanging versus castration for the crime of rape as part of a larger discussion on lynchings throughout the South.
} 
of lynching, often marked with intense hatred and inhuman acts of savagery, appalled him. He wrote, "What a curse to cultivate, and see grow, is lynching. Just think of it a moment. And in a country whose million church spires deck the sky, and whose constitution vouches to every man the sacred right of a trial by a jury.” Accordingly, as much or even more to blame than those who participated in a lynching, were those who condoned it, church congregations and state and national law makers. ${ }^{173}$ Claiming, "Lawlessness has sway enough now without those in authority giving way to it,” Clifford believed that it only took a small number of courageous men to prevent a lynching. Clifford pointed to Dr. McSherry, Capt. Colston and Archibald Oden who, guns in hand, stood on the Cumberland Valley bridge and defied a raging mob intent on lynching a black man; a man they took back to jail and who later proved himself innocent. ${ }^{174}$

If the Taliferro lynching in 1884 helped to shape the course of Clifford's life, it was the burning of Zach Walker in Coatesville, Pennsylvania, in 1911 that forced him to declare, "in regard to lynchings, burnings, and wholesale murdering," the "limit is being reached." Calling it "one of the most revolting and brutal crimes in the criminal history of the United States," Clifford claimed that there was "no need of a foul recourse to murder to pay for a supposed murder." There was no possibility of escape; Walker was inside a hospital under police guard with his bullet-ridden body bound to a cot. Clifford wrote, "these American savages were so thirsty for the blood of their terrified victim, that they carried him and the cot on which he was lying, and threw man and bed into the fire." Clifford felt that only a unified and "manly contention” against the wrongs committed on African Americans would bring an end to the lynching, and lead to fullfledged manhood rights for black men. ${ }^{175}$

\footnotetext{
${ }^{172}$ Pioneer Press, August 8, 1914.

${ }^{173}$ Pioneer Press, August 5, 1911.

${ }^{174}$ Pioneer Press, August 16, 1913.

${ }^{175}$ Pioneer Press, August 19, 1911; Pioneer Press, September 16, 1911.
} 
For Clifford, "manly contention” meant having the courage to stand up for your rights and principles. Clifford wrote, "I have always contended that I was a free man, and hate servility in the blood of a Negro. If I tamely submit to wrongs, I am a coward.”176 He felt that those who did not contend for their rights, did not deserve them. Clifford also associated manhood with the issues of education and class, with neither limited due to heritage or income. Clifford urged his readers not to find fault with "the place you are cast in," claiming, "you need not be a horse because you were born in a stable.” Clifford believed a man could elevate himself, as he did, through hard work; and although it may be difficult, "who expects to find cherries without stones, roses without thorns?"177 The impact of education and manhood on one’s class appeared frequently in his writings, particularly in the following debate on the status of hotel waiters in society:

We see no reason why a hotel waiter, if he is honest, should not be recognized as a gentleman, in the very best society, providing he has enough education and polish to make himself agreeable. We wish to say, however, that we fail to see how an educated man can make himself at home and feel dignified in the capacity of a hotel-waiter. To work in a hotel in order to make money to get an education is all right, but to obtain the education and return to the hotel, is an exhibition of a lack of pluck; a lack of self-confidence and a sure sign of a low individual estimation. We do not wish to be understood as meaning that hotel work is disgraceful; but we do claim that there is work more honorable, and that it is the duty of our young men to find it—education is the lamp and perseverance the pathway to it. ${ }^{178}$

In contrast, those lacking in education and manhood frequently lacked the racial pride and moral

principles required to achieve full manhood rights:

No other town or voting place in this state can be named where Negroes acted worse, or as uncivilized as they did here on election day. At the market house precinct fully sixty stood around like balky horses offering themselves for sale, and because they were not bought, fully two-thirds of them would not and did not vote. What a shame! What a disgrace! Any class of people who faced segregation, Jim-crowism and disfranchisement,

\footnotetext{
${ }^{176}$ Pioneer Press, October 12, 1912.

177 “Don't Whine” Pioneer Press, October 1886.

${ }^{178}$ Pioneer Press, February 1887.
} 
and would not vote to defeat same, have no right to vote. ${ }^{179}$

Not only did Clifford associate the rise of Jim-crow with lower class African Americans, his personal experiences led him to believe that they undermined efforts to achieve racial equality. Clifford wrote that African Americans should agree to disagree and not to disparage each other for different points of view, but "as it is if those who have striven to educate themselves up to the level of the age dare accord with its opinions, the groveling class are bickering, yapping and snapping over it with an avowed determination if possible, to ruin them, which is absolutely wrong."180 Indeed Clifford believed that if blacks would stop giving "hundreds of thousands of dollars yearly to jim crow shows, picnics and camp meetings,” and support black businesses (especially black newspapers), "the death knell of hatred would prevail, and the race [would] be 500 per cent better off. ${ }^{181}$

Clifford's perception of class also shaped his views on religion. A religious man, Clifford believed in an educated ministry and often opposed uneducated ministers and the emotional religion they preached to the masses, feeling many of them lacked the spiritual or moral conviction needed to lead the race. Conversion, according to Clifford, led many to believe that God called them to preach although they were unqualified to do so. Claiming that "to preach is to teach,” he maintained that the qualifications for a preacher were "virtue, industry, Godliness,” and “intelligence or uncompromising determination to acquire it," and that "to be called and not qualified, and no desire to be, is a sure sign that the Lord had nothing to do with it.” In fact, Clifford maintained that "it is now in order, when a youngster has no special liking for work, and is 'subject to fits' to apply for a license to preach, and it seems that the powers that be, 'feel duty

\footnotetext{
179 Pioneer Press, November 7, 1914. The italics used on the word “class” are the author's, not Clifford's.

180 Pioneer Press, March 1887.

181 Pioneer Press, September 27, 1913.
} 
bound to license the poor fellow.' 'Verily, the sun do move.",182 Those who suffered from the delusion of being called, although unprepared, and those who preached because they were too lazy to do anything else, Clifford referred to as "Jack-leg Sky Pilots” and "Supplejacks.”

Clifford wrote, "Hell and the devil as we see it are in man, and especially jackleg skypilots. What fool would hold up his hand that he wanted to go to an imaginary fiery region? Heaven is a condition, not a place and he who hasn't it in him here below will enjoy none of it hereafter." He maintained, "any one who believes in a veritable devil and his hell-fire of brimstone, can't love and serve a just and loving God without the fear of the devil” and that "God should be loved and served because and only because He is so just, kind, loving and good.” According to Clifford, preachers and parents who taught their children to believe in a literal hell also taught them fear, the worst thing they could do if they wanted "to make manly men and womanly women of them.” He claimed that any one who preached a hell-fire religion was a fool, and that preachers who ranted and snorted to get dollars and cents "ought to be well singed in a man-man brimstone fire."183

Included in this group were well-known evangelist Billy Sunday and numerous faith healers who appeared throughout the country in the early twentieth century. On Rev. Sunday's ministry Clifford wrote, "What a pit that the standard of Christianity has ebbed so low, that a Billy Sunday—a reputed professional ball player—can prove Barnum's theory correct. What would the past, present and future ages think of the lowly Nazarene, had He a prize fighter with him to flog those who got unruly?” Referring to faith healers as "ignorant beats," Clifford told how they could restore eyesight, tell fortunes, put on or take off spells, and do "all manner of wonders." He believed that blacks would go to see them about as long as they would continue to

\footnotetext{
${ }^{182}$ Pioneer Press, May 1887.
} 
yell their amens to the preaching of "light-headed, local preachers and licensed supplejacks." He concluded that "at the rate religion is going to pieces, a belled buzzard may do a stunt or two."184 In contrast to the "sky-pilots" he frequently admonished, Clifford maintained that a man called to preach could be identified from "his voice swelling from the lowest to the highest pitch, his face flushed, his gestures preceding the sentiment, and the whole demeanor of his body in deep sympathy and union with his plea. In this way the gospel should be preached, and he who loves God Supremely will do it.” A good minister united his parishioners, preached a gospel that reached all without catering to a few, encouraged Christians and forewarned sinners, and did not use the pulpit to chastise individuals or appease his anger. ${ }^{185}$ Although "few and far between," Clifford encouraged the efforts of educated ministers stating, "Trust in God and do your duty, for the harvest is ripe here and the reapers are few."186

Clifford fought for more than forty years to establish a "clean, moral, intelligent and religious ministry." 187 That fight placed Clifford and the Pioneer Press into the position of "moral watchdog," and often resulted in graphic attacks on ministers in the columns of the Press who Clifford felt lacked both morals and Godliness. Inevitably, some of those attacks resulted in lawsuits against him for libel. Claimed a "general fondness of this class of Negro preachers for women has done our race more harm than saloons," he did his best to remove them from the community. ${ }^{188}$ One of Clifford's attacks was on Rev. Kirk, a Baptist preacher, who Clifford insisted "sought the lowest company of girls in the town" much to the disgust of respectable men

\footnotetext{
${ }^{183}$ Pioneer Press, December 2, 1916; April 1, 1916; February 19, 1916.

${ }^{184}$ Pioneer Press, February 17, 1912; June 14, 1914. P.T. Barnum’s theory was “There's a sucker born every minute.”

${ }^{185}$ Pioneer Press, February 1887.

${ }^{186}$ Pioneer Press, December 16, 1916.

${ }^{187}$ Pioneer Press, December 16, 1916.

${ }^{188}$ Pioneer Press, February 11, 1911.
} 
and women of both races who had witnessed him in "disgraceful positions." ${ }^{\text {"189 }}$ However, it was his attacks on the Rev. J.C. Newman and his wife Hattie of Hagerstown, Maryland, and the Rev. George E. Curry and his daughter Mamie that led to libel suits against Clifford as proprietor and editor of the Pioneer Press.

On June 3, 1899, Clifford printed an article on the Rev. J.C. Newman of the Free Baptist Church of the Shenandoah Valley, who, when preaching on several occasions at Storer College, prayed for Clifford and stood on the rostrum "batting his eyes like a toad in the ashes, shaking and ducking his shallow head and begging the Lord to have mercy on us." Clifford wanted no prayers from a man he had "seen skulking in the bushes with a noted prostitute" as well as involved in a public scandal in Hagerstown just a few weeks earlier. Questioning whether or not Newman and his wife were legally married or just living together, Clifford went on to relate that in addition to Rev. Newman's transgressions, the said minister had recently caught his wife in bed with another man, a scene Clifford described in graphic detail. The scandal led to a public investigation since both Newmans were public school teachers, but both remained active in the church. Clifford wrote that "he preached and she played and sung in the church, and so they live to demoralize the young under the guise of religion." Asking, "Who blames an editor for objecting to such a moral leper and malodorous scamp as John C. Newman, praying for him in public?,” Clifford concluded, “There is no place in hell hot enough for such dirty scoundrels.”190

Of course the Newmans sued Clifford for libel and slander, thereby "imputing the chastity of a woman” and the case came before the September 1901 term of the Circuit Court of Berkeley County. Clifford entered a plea of "Not Guilty," however, the jury disagreed and fined him $\$ 100.00$ and the cost of prosecution and ordered him imprisoned in the Berkeley County jail until

\footnotetext{
${ }^{189}$ Pioneer Press, September 6, 1890.
} 
all the costs and fines were paid; but not to exceed sixty days. Based on new evidence, Clifford requested a new trial to hear the testimony of witnesses who could show that what Clifford printed was not slander, but the truth. The court refused. Clifford provided bond, filed four bills of exception, and procured a writ of error and supersedes. Interestingly enough, one of the bills of exception Clifford filed was on the prejudicial and improper language the prosecuting attorney, U.S.G. Pitzer, used in his closing argument before the jury. Pitzer, referring to Clifford, stated, "If he had been born a beast, would have been a polecat; if he had been born a bird, would have been a buzzard; if he had been born a reptile, would have been a lizard; if he had been born a fish, would have been a mud cat; and if a man, a libeler.” Apparently Pitzer was still angry over his 1898 election loss that Clifford orchestrated. Despite Clifford's arguments, in 1906 the West Virginia Supreme Court of Appeals voted to uphold the judgment of the circuit court. ${ }^{191}$

The Curry case resulted from an article that appeared in the Pioneer Press on March 12, 1904. In an article titled "George, Jim and Mamie” and signed “A Church Member," the author maintained that Curry misused $\$ 509.00$ of public money and attempted to cheat two businessmen out of $\$ 150.00$. His daughter Mamie, a school teacher in Berkeley County, received criticism because of her relationship with Jim Reed, a notorious "loafer, crap-shooter, gambler and girl destroyer." Exacerbating the situation was the fact that Rev. Curry supported and encouraged the relationship. The writer claimed, "Now you good people have samples of our preacher and teacher. Would you have either?” Clifford also targeted George Curry in an article titled “Are They Lies or Truths?” Once again, Clifford lost the case in the Berkeley County Circuit Court, but it was not appealed to the State Supreme Court. ${ }^{192}$

However, despite his two losses, Clifford continued to serve as a moral watchdog to the

\footnotetext{
${ }^{190}$ State v. Clifford, West Virginia Supreme Court of Appeals, 6 February 1906.
} 
community. In 1912, twelve years after Clifford was found guilty of libel in the Newman case, Clifford wrote another article on Newman. A local minister, Rev. Beane, invited Newman to speak from the pulpit at a funeral, leading Clifford to insist that it was "a shame on society and on the alleged respect for religion” to invite a man like John Newman into a church. He added, "While preaching in Hagerstown, he ruined a young girl; sent her to Washington, D.C. where she became a mother. He was arrested, tried and convicted for it and is now supporting the child by

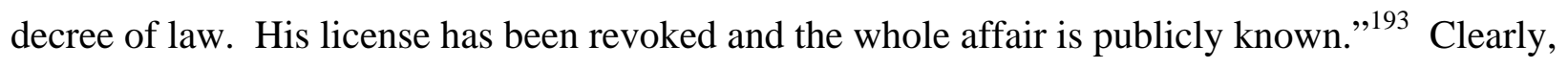
the article was a very public "I told you so.” Regardless of the possible consequences, Clifford continued to publish the truth as he perceived it ... no matter how much it cost.

Clifford did not believe in a literal "heaven” or "hell," fire and brimstone, or an angry revengeful God. He did not believe that "baptism under running water" did any good; it was alright, but not essential to salvation. In truth, Clifford associated baptism with "Jack-leg sky pilots," and balked at "the idea of an ignorant man compelling an intelligent one to go into running water in bleak weather.” He did believe in a just and loving God, morality, kindness, and the brotherhood of mankind; and he believed in the hereafter, where he would look for "better things and expect to see the sights of glory." ${ }^{194}$ Clifford frequently wrote about the importance of following the Golden Rule. He also quoted the words of Thomas Paine, "The world is my home and to do good is my religion” as well as Robert Ingersoll’s declaration, "When you white Christians take the black man into churches and treat him as a brother, I'll join your church.” And claimed "both gospels are good enough for Clifford."195 Officially, Clifford and his family belonged to the Mt. Zion Methodist Episcopal Church, although he often attended the services

\footnotetext{
${ }^{191}$ State v. Clifford, West Virginia Supreme Court of Appeals, 6 February 1906. (Newman case).

${ }^{192}$ Pioneer Press; Curry v. Clifford, Berkeley County Circuit Clerk’s Office.

${ }^{193}$ Pioneer Press, May 4, 1912.

${ }^{194}$ Pioneer Press, March 4, 1910.
} 
and camp meetings of other churches in the area. In doing so, he observed: "The unfortunate feature about the mass of Negroes is if you ask them what they are doing, the reply will be preparing to die. There is no death to those who prepare to live. Do that with all your might, and what you call death will be only a sweet transition. . ..”196

Meekness was something Clifford never associated with religion. In 1916, he wrote, "The editor of this paper never believed in the theory that to go to heaven, after a fellow smacks one cheek, he must lamb-like turn the other. Strike back and hard at that, is his policy, and if it keeps him out, he has had some consolation here.”197 As much as he looked forward to his reward in Heaven, Clifford was more than willing to stay on earth and do one more battle for the race.

When he was sixty-five years old he wrote:

Regardless of the fact that the editor of this paper is an old gray headed man and craves to live in the 'sweet fields of Eden' after treading the thorny paths of this life, and if it were possible for him to stand on this side of the Jordan, see the gates of glory wide open, the four and twenty elders and the army that John saw, the golden paved streets and the river of life, and loved ones beckoning him to come, and some one would whisper Clifford: Cole Blease, Jim Vardaman, John Sharpe Williams and Hoke Smith want to put the gloves on with you, we would right about face and agree to take the four in quick succession giving to each one 8 minutes, and be a happier man on earth, than we could have been in heaven. ${ }^{198}$

In addition to "Jack-leg sky pilots,” Clifford also targeted the moral character of school teachers in the black community. In at least one case, he warned both the public and the teacher of what was to come when he stated, "We intend to sprinkle a little salt on the raw of that Negro

\footnotetext{
${ }^{195}$ Pioneer Press, September 12, 1914.

${ }^{196}$ Pioneer Press, December 12, 1914.

${ }^{197}$ Pioneer Press, January 15, 1916.

${ }^{70}$ Pioneer Press, February 13, 1914. Coleman Livingston Blease (1868-1942) was governor of South Carolina and a United States Senator from 1911-19; James K. Vardaman (1861-1930), editor of the Greenwood Commonwealth, served as governor of Mississippi from 1904 to 1908 and United States Senator from 1913 to 1919; John Sharpe Williams (1854-1932) of Mississippi served as a United States Representative from 1893 to 1909 and as a United States Senator from 1911 to 1923; and Hoke Smith (1855-1931), lawyer and owner of the Atlanta Journal, served as governor of Georgia between 1907 and 1909 and in 1911, Secretary of Interior under President Grover Cleveland from 1893 until 1896, and as U.S. Senator from 1911 to 1920. All of these men, particularly Vardaman and Hoke, were well know for their racist politics.
} 
school keeper of Keyser in our next issue. Whenever a Negro assumes to teach colored children and to hold his job, plays to the galleries of the foes to race, manhood, and womanhood, it is the right time for him to skedaddle, and if he lacks the nerve to go, a little of that stuff put on the mule might help matters.” In the following weeks, Clifford published two letters from Alex Redmond of Keyser, West Virginia, on "Professor” Fuller, the teacher at the African-American school in that town."199 Redman reported that Fuller was keeping a young girl at the school for hours after school was out, "styling her his secretary.” After his obsession with girl led to his wife leaving him, Fuller moved into the house where the girl lived. Redmond wrote, "Fuller is a fraud, has not the thorough training necessary for a man who lays claim to the distinction he tried to make himself enjoy, and for the moral good of this town he deserves a nice coat of tar and feathers." Clifford printed an article on Fuller in the same edition, stating "the scandal is going to be probed to its lowest depths. The only real remedy for this class of Negro school teachers is castration.,200

Clifford became involved in another case after two women appeared on his doorstep in January of 1915. One of the young women engaged Clifford as her lawyer and then proceeded to give a detailed account of her love affair with Martinsburg schoolteacher "Randolph” Fredrick Ramer. The next day, the young woman went alone to Justice Lloyd's office and swore out a statement naming Ramer as the father of the child she was carrying. Two days later, the young woman, Ramer, and her sister, along with several witnesses, Will Marshall, Frank Briscoe, Dan Snyder and John Carton, returned to Justice Lloyd's office and swore that Clifford forced her to appear before the justice and claim Ramer as the baby's father. The accusation only heightened Clifford's indignation, along with his effort to reveal the truth. Clifford could prove that the

${ }^{199}$ Pioneer Press, May 27, 1911; Alex Redman, “Professor Fuller Given a Roast,” Pioneer Press, June 3, 1911. 
young woman revealed to a witness that Fredrick Ramer took her and Frank Briscoe before Dan Snyder and paid her fifty dollars to deny that Ramer was the father, and then paid both her and Dr. Samuel Gray's fares to Washington, D.C. so she could give birth to the baby out of state. However, the plan failed and a relative of Ramer's took the child following its birth in nearby Kearneysville. ${ }^{201}$

Clifford described Ramer as a consummate liar, stating that Ramer never graduated from Storer College as he claimed. Instead, Clifford maintained that school officials expelled him from Storer after they discovered him hiding in the coal box of a girl's room in the women's hall. Clifford also maintained that Ramer, although principal of the Martinsburg city school for more than ten years, had taught less than two years when one of his students "preferred black charges against him and he was ousted.” In addition, Clifford claimed that Ramer's wife forced him to stay away from another woman on one occasion and, later, cowhided him at the B\& O railway station for his indiscretions. ${ }^{202}$ Writing on the class of school teachers who seduced their students, Clifford said, "How persons who lay claim to education and morality can destroy womanhood and try to look wise, in the face of infants in young girl's arms, is shamefully strange. ${ }^{203}$ Surprisingly, none of the school teachers Clifford targeted filed lawsuits against him. Education was important to Clifford, and he constantly advocated for better education, better schools, and better teachers for African Americans. He summed up his thoughts on education best in a piece titled "True Education:”

If there were no more of man after finishing up this life, his education would be as all other animals—natural, the same today that it was six thousand years ago. But the fact that man lives hereafter, is evidence why he should be taught to think and act for himself intelligently through life. The successful men and women of this and all other ages, are

\footnotetext{
200 “Professor Fuller Given a Roast;” J.R. Clifford, “Prof(?) Fuller, B.S.—Beat Shyster,” Pioneer Press 3 June, 1911.

${ }^{201}$ Pioneer Press, January 23, 1915.

${ }^{202}$ Pioneer Press, January 27,1915; January 30, 1915.

${ }^{203}$ Pioneer Press, July 1, 1914.
} 
those who had good teachers at home, and better ones in the school-room. Such teachers as urge their pupils to contend for what they believe to be right and to cheerfully yield when convinced of their wrong. The curse of this age is low pay and consequently poor teachers (?) who simply teach the boys and girls to be conceited by the cramming system, and make them believe, when really they know nothing, that they know all that is to be known. The schools and colleges that send young men out into the world as book worms, cripple them for life. The duty of every institution of learning is to arouse an anxiety in the youth's mind to know more and more, and to be determined to search for it. When such is the case, the world soon endorses his diploma and success meets him on every hand. ${ }^{204}$

Clifford was proud of the children he helped to turn into respectable adults. When he wrote about his work as principle, he often included statements about his "relentless warfare against the low grade of teachers (?) in Berkeley County” and insisted that he never gave up until the board replaced those teachers with qualified, moral teachers. However, the lack of good facilities also bothered him. ${ }^{205}$ Clifford was complaining about the school facilities for black children in Martinsburg when he resigned in 1886; he was still complaining in 1906; and ten years later in 1916. The only black school in Martinsburg was the small "insignificant school” the Freedman's Bureau built fifty years ago. One story, surrounded with a bull-board fence and lacking pavement in front of it, the Board of Education claimed they could not afford a better school for African Americans. Yet as Clifford noted, they were able to afford fine school houses for the white children in Berkeley County, including five in the town of Martinsburg. ${ }^{206}$

Clifford particularly disliked the evolution of graduation ceremonies for the black primary schools. He claimed that it was absurd for the school board and its superintendent to promote "the graduation of the poor little Negroes from the poor little one horse schools" when white children are compelled to go through all the grades of the ward schools, then given instruction from well-educated principals for years, only to be sent to high or grammar school for four more

\footnotetext{
204 “True Education,” Pioneer Press, October 1886.

205 “Commencement Misnomer,” Pioneer Press, October 14, 1916.

206 “Commencement Misnomer;” Pioneer Press, May 31, 1916.
} 
years before they could graduate. Recalling a few years earlier when a large crowd gathered to see approximately a dozen African-American children get their diplomas, he stated that none of those who received them had enough education to get a certificate to teach school and that they all had "to go into kitchens or play on their poor old mothers' washboards to live and dress."207 Clifford did not blame the parents. He pitied them for the majority believed their children to be educated when, in fact, they were not. Graduation ceremonies, Clifford maintained, were only for show, established to deceive the parents” whose own knowledge was not sufficient to grasp the facts." Claiming "children should not be made believe they have done wonders when in truth, it is doubtful if they have gotten the real rudiments of an education," he insisted that if the board of education had the sincere interest of the children at heart they would keep them in school four years longer and provide the best teachers that money could buy. ${ }^{208}$ The parent's role, according to Clifford, was to support and encourage a child's education, particularly the skill of reading:

If parents of Negro children only knew the incalculable value of reading, what a blessing it would be to our race. When their poor little tots barely get enough in the public schools to add, subtract, multiply and divide and scarcely prove solutions in last two fundamental principles of arithmetic, they are graduated, and given diplomas. God pity them, we pray. Show us a reading people, and we'll show you the people who are sure to rule the world. ${ }^{209}$

In addition to reading, Clifford felt parents had an obligation to instruct their children in manners and behavior. He often used his friend, John J. Healy, as an example of how parents should interact with their children. Clifford reported that Healy and his family all marched into dining room after Mrs. Healy rang the bell for dinner. The family took their seats while Healy stood, helping them all get seated while engaging pleasantly in conversation. Clifford, like

\footnotetext{
${ }^{207}$ Pioneer Press, May 31, 1916.

${ }^{208}$ Pioneer Press, May 31, 1916.

${ }^{209}$ Pioneer Press, September 27, 1913.
} 
Healy, believed that dinner should be a family affair where everyone engaged in the conversation, gathered information, and discussed events. Therefore, by selecting and preparing stories for the children and holding interesting discussions, dinner time became the perfect time to teach. ${ }^{210}$ Fond of big families, Clifford viewed home and family as the foundation of life. Not only did charity begin at home, but also "morality, cleanliness, industry, economy and the religion that lasts and blesses the world," which, in turn, led to "good schools, good churches, good governments and good courts."211

Despite his Victorian vision of home and hearth, Clifford was progressive when it came to sex education for teenage children. Concerned over the increasing rates of venereal disease among African Americans, Clifford described those who refused to discuss the issue with their children at home and opposed discussions on the topic at school or in church as "nasty nice" people. Clifford maintained their attitude toward sex education was "a flagrant admission that it is better for their children to have the loathsome disease, than to make them wise to avoid it.” He openly advised "throwing prudery into the deeps of the sea of forgetfulness" and attacking it publicly. ${ }^{212}$ When asked what kind of man he would accept as his son-in-law, Clifford said he had three requirements: that he was naturally industrious; that he was honest; and that he submit to a blood test for venereal disease. If he had the disease, according to Clifford, "he would never call me father.,213

Fearful of the impact alcohol, smoking, gambling, and prostitution made on black children, Clifford frequently complained of the bars and brothels established in black neighborhoods. As white reformers of the Progressive Era sought to eliminate these evils from

\footnotetext{
${ }^{210}$ Pioneer Press, July 1887.

${ }^{211}$ Pioneer Press, August 9, 1913.

${ }^{212}$ Pioneer Press, January 17, 1914.

${ }^{213}$ Pioneer Press, February 11, 1911.
} 
their communities, they frequently pushed those businesses into black communities where the majority of progressives found it easier to "turn a blind eye" to their activities. Clifford criticized whites who spoke disparagingly and damned blacks while running white prostitutes out of their own neighborhoods "to live in what prejudice and ignorance call Africa." Those who came to “Africa” for pleasure frequently engaged in ringing bells, drinking, fighting, cursing, and, more often than not, shootings. They also exposed themselves before black children, who witnessed all types of men traveling into and out of the neighborhood, both day and night. Clifford described prostitution as "one of the greatest curses that ever beset the world." ${ }^{\text {,14 }}$ His efforts to get blacks and whites to work together to eliminate houses of prostitution was unsuccessful and his repugnance was apparent in an editorial marking the New Year in 1915:

The 'niggers' of Martinsburg start out in the year of our Lord 1915 with the gifts the city and the Courts have allowed them to have for years, two dirty white houses of ill fame. These festering hells have been forced from all other places where whites lived, yet nevertheless, grand juries will not indict them, nor the preachers unite to help crush them out. Do the white Christians think they are good teachers for the 'niggers' and their children? Is there another class of people would stand it except the 'niggers?' No! and no! again! How can children grow up decent in the sight of such hellish filth? ${ }^{215}$

The battles never ended. For decades, Clifford's little "bark on the sea of journalism” sailed through turbulent times and weathered numerous storms. It survived, a testament to Clifford's tenacity, where numerous others failed. In West Virginia alone, between 1870 and 1930, African Americans established more than twenty-five black newspapers, most of which failed within a year or two. ${ }^{216}$ Lacking money and hindered by prejudice, it took significant time and energy to establish, support, and maintain the day to day operations of a black newspaper. After thirty-five years of publishing the Pioneer Press, Clifford was growing weary. In the spring

\footnotetext{
${ }^{214}$ Pioneer Press, September 6, 1913.

${ }^{215}$ Pioneer Press, January 9, 1915.

${ }^{216}$ In addition to the Pioneer Press, the two longest running black newspapers in the state were the McDowell Times (1904-1941) and the Charleston Advocate (1907-1912).
} 
of 1917, he wrote:

This paper is thirty-five years old today, March 2, 1917. It has been put to many crucial tests; fought and won many victories. Politicians have tried to kill it three times; an old Presiding elder stamped it under his feet in pulpits over this state and called it 'a dirty democrat sheet;' it has elected and defeated congressmen. Its editor thirty days in jail, innocent as was Paul kept it going; and now, in his hoary age having fought in the war that freed 4,000,000 slaves, with increasing aches and pains, deserves a rest. ${ }^{217}$

The Pioneer Press closed its doors in October of 1917. An article in the McDowell Times, a black newspaper published in McDowell County, West Virginia, stated, "Hon. J.R. Clifford, who has been in the paper business for at least forty years, has been forced to suspend the publication of The Pioneer Press.” The Times suggested that the length of the suspension would depend on Clifford's health. ${ }^{218}$ Clifford reported injuries or poor health at various times throughout his career. He sustained injuries at least twice: a bicycle accident resulted in a broken little finger on his right hand, sprained both wrists, and left him with acute neuritis; and the three heavy blows U.S.G. Pitzer administered to his head in the courtroom in 1898 damaged his nervous system. In addition to his injuries, in two letters written in January of 1899 to Hon. J. Holly, Clerk of the Supreme Court, concerning payment for the Williams case, Clifford stated that he was ill, but did not elaborate. However, he did report in a Declaration for Increase of Pension filed in March of 1905 that he had "heart trouble.” In October of 1912, the Pioneer Press reported that Clifford was “critically ill,” an illness that resulted in the calling of J. Paul Clifford, who was now living in Mechanicsburg, Pennsylvania, to his beside. At that time, his oldest son, Albert, was working at the Pioneer Press with his father. ${ }^{219}$

Still, Clifford apparently recovered, for he frequently walked the five miles between

\footnotetext{
${ }^{217}$ Pioneer Press, March 3, 1917.

218 "Pioneer Press Suspends Publication," McDowell Times, October 5, 1917.

${ }^{219}$ Letter from J.R. Clifford to J. Holly, January 12, 1899; Letter from J.R. Clifford to J. Holly, January 25, 1899; Pioneer Press, October 26, 1912; Declaration for Increase of Pension, Bureau of Pensions, December 17, 1901; Declaration for Increase of Pension, Bureau of Pensions, March 16, 1905.
} 
Shenandoah Junction and Charles Town in the years that followed his illness rather than ride the segregated Norfolk \& Western Railroad. He also reported in 1915, “The harder I work the better my nerves are, and although in my $68^{\text {th }}$ year, I am as active as ever, and can shoot with as much accuracy as ever, and I certainly could fight for my country.” After the Pioneer Press closed, he remained active in the American Negro Academy and continued to practice law in Martinsburg and the surrounding area. In fact, on the same day that the McDowell Times reported the suspension of the Pioneer Press, it published an article written by Clifford on the front page in which Clifford called for a black man to be appointed to the Workman's Compensation Department in West Virginia. Typical of his confrontational style, Clifford claimed the appointment would be "scant recognition to a race of people who compose 28,000 of the electorate of the state" and that "the Negro everywhere is tired of doing all the voting, and none of the office holding, and those of the 'Little Mountain State' are going to become no exception to this new rule that they have inaugurated for their political rights." ${ }^{220}$ Clifford's spirited rhetoric suggests that he was not critically ill despite his history of injuries and illnesses.

Family members maintain that Clifford's vocal opposition to blacks' participation in the war led the federal government to close the newspaper under the federal sedition acts established during World War I. However, articles that appeared in the Pioneer Press gave no indication that government censorship was responsible for the paper's demise. Given Clifford's personality, if he knew he was being targeted, he would have reported it in the Pioneer Press. An examination of Department of Justice case files reveals no investigation of Clifford or the Pioneer Press. ${ }^{221}$ Yet

\footnotetext{
220 "Attorney J.R. Clifford," McDowell Times, October 5, 1917.

${ }^{221}$ Theodore Kornweibel, Jr., Ed., Federal Surveillance of Afro-Americans (1917-1925) (Fredrick, Maryland: University Publications of America, Inc., 1986). A microfilm project on sources from the National Archives, the work includes a guide and twenty-five rolls of microfilm on the federal surveillance of African Americans from the United States Department of Justice, the Federal Bureau of Investigation, the War Department, Records from U.S. District Courts, the U.S. Department of State, the Office of Naval Intelligence, the U.S. Shipping Board, and the U.S.
} 
there is no denying that Clifford often opposed the war as well as United States foreign policy. He also had, and expressed, little regard for Woodrow Wilson. However, those criticisms usually included comments on the loyalty of African American and their willingness to fight for their county. Clifford, despite his age, maintained that he was willing to fight if only to prove, once again, that blacks were "truly Americans," and, as such, deserved all the rights and privileges of American citizens. Clifford wrote, "In fighting I would feel that for the second time I would be shooting hatred to eternal oblivion, in the hope that a just God would make our half freedom a whole manly one."222 He maintained: "Our rights are ours to enjoy only by fearless agitation and contention, and the party or parties who are too cowardly to do both, are undeserving of their rights. We fought for them and why not talk for them, for 'peace hath her victories, no less renowned than war.,",223

Indeed, Clifford never surrendered his “contention for every right vouched safe by the constitution of this country.” After raising his sword on the battlefields for freedom during the war of rebellion, he eagerly engaged in another war for racial equality and justice; and in battle after battle, the Pioneer Press served as his weapon.

Postal Service. The project did document the federal surveillance of a few African Americans in West Virginia. There were no records on J.R. Clifford in the documents.

${ }^{222}$ Pioneer Press, June 6, 1915.

${ }^{223}$ Pioneer Press, December 5, 1914. 


\section{CONCLUSION}

\section{"WHOLLY BY OUR CHARACTER:"}

The Measure of a Man

"The measure of the progress of civilization is the advance of personal liberty. Destroy personal liberty, and you chain civilization to its dead body, where it will remain prostrate and helpless, until the devastating influence of national sin and neglect, like a cancer, have eaten out its life and built upon its ruins, the throne of despotism and degradation."1

In January of 1922, Carter G. Woodson printed an article titled "Early Negro Education in West Virginia” in the Journal of African American History. When John W. Cromwell read the article, he wondered why there was no mention of his friend, the outspoken race advocate J.R. Clifford. At the American Negro Academy meeting that year, Cromwell approached Clifford and asked if Clifford had seen the article. When Clifford answered “yes,” Cromwell gave him a questioning look and asked, "What have you done to the Negroes of your state, they keep you in the back ground?” Clifford later wrote “[I] Of course, didn’t know.””

Regardless of whether or not the younger black leaders who emerged in southern West Virginia at the turn of the twentieth century recognized or acknowledged Clifford's early leadership in the state, he had a significant influence on them. For nearly sixty years, Clifford fought against racial injustice: from Civil War battlefields to the segregated railroad cars of the South; from rural courtrooms in the hills of West Virginia to the Presidential office of the White House; from the columns of a "modest” four-page paper called the Pioneer Press to the podiums of some of the nation's greatest lecture halls. As the first African American lawyer to practice in the state of West Virginia and one of the few black lawyers south of the Mason-Dixon Line, Clifford paved the way for the next generation of black attorneys who followed in his footsteps,

\footnotetext{
1 J.R. Clifford, “Annual Address to the National Independent Political League,” Pioneer Press, September 2, 1911.

2 Letter from J.R. Clifford to Carter G. Woodson, February 4, 1923, Box 5 Reel 3, Carter G. Woodson Collection of Negro Papers and Related Documents, Manuscript Division, Library of Congress, Washington, D.C.
} 
men such as T.G. Nutter and Harry Capehart whose work in the West Virginia State Legislature and the N.A.A.C.P. carried on Clifford's commitment to civil rights. Along the way, he forced school officials in West Virginia to adhere to the laws pertaining to "separate but equal” schools in the state and challenged those laws in court, secured equal pay for African-American teachers, and physically demanded that courtrooms in West Virginia carry out the decision handed down in the Supreme Court case Strauder v. West Virginia giving African Americans the right to serve on juries.

It was he who helped to lay the groundwork for the N.A.A.C.P. branch in West Virginia; an organization that had remarkable success in the 1920s under the leadership of rising black lawyers in the state. In the 1920s, African Americans in West Virginia organized eleven N.A.A.C.P. branches in southern West Virginia. Civil rights leaders in the state maintained the right of African Americans to sit on juries when they won a state Supreme Court decision in 1919 ensuring blacks would be called for jury duty. In 1921, the state N.A.A.C.P. and black legislators led a successful campaign to get an anti-lynching bill passed in the state legislature. In addition, the state provided increased funding for black schools and organizations. When the N.A.A.C.P. held its annual meeting in Newark, New Jersey in June of 1922, it shifted its strategy toward electoral politics, actively supporting politicians who would support the federal Dyer antilynching bill. Based on the N.A.A.C.P.'s success in West Virginia, T.G. Nutter, a prominent black Republican attorney from Charleston, West Virginia gave a presentation titled "What a Branch May or May Not Do in Politics” intended to establish guidelines for branches across the nation. Whether or not T.G. Nutter was aware of Clifford's influence, it was Clifford's words that echoed from the podium. Nutter claimed that while the N.A.A.C.P. was non-partisan on a 
national level, on a local level branches should endorse candidates when real principles were at risk. In addition, there were principles that branches should follow in politics such as: politicians should not be branch presidents; branch leaders should not take gifts from politicians; and branches should support men and measures, rather than parties. ${ }^{3}$ Two years later, Charleston businessman C.H. James, head of the black Democrats in West Virginia, wrote a letter to Clifford's fellow editor and friend, Harry C. Smith, in Cleveland, Ohio. He told Smith, "We are booming things here. I am trying to lift the standard of politics among our people here to the standard you have got yours, then I will tell them to vote for men and measures.” In a true demonstration of the "independent politics" Clifford often called for, Republicans and Democrats alike in the state were quoting his words. ${ }^{4}$

So, why, as Cromwell asked, was Clifford left out writings such as Carter G. Woodson’s “Early Negro Education in West Virginia” (1921) and A.B. Caldwell’s West Virginia edition of History of the American Negro (1923)? One reason for his "oversight” was the geographical shift in the black population due to industrialization. Following the Civil War, black leadership emerged in cities throughout the state as African Americans sought to establish schools and churches along with beneficial and fraternal organizations. Many of these leaders joined together for political action. However, with the migration of large numbers of African-American workers into the state between 1880 and 1920, the balance of political power among African Americans shifted to southern West Virginia, where the increasing number of black voters wielded more and more political clout. In addition to southern West Virginia becoming the focal point of black politics, Clifford's conflict with local Republicans led him to shift his focus away from the state

\footnotetext{
${ }^{3}$ Mark Robert Schneider, “We Return Fighting”: The Civil Rights Movement in the Jazz Age (Boston: Northeastern University Press, 2002), 185, 200-201.

${ }^{4}$ Letter to Harry C. Smith from C.H. James, October 27, 1924, File 18, James Produce Papers, West Virginia and Regional History Collection, West Virginia University, Morgantown, West Virginia.
} 
toward national politics and alliances where, as a member of Du Bois’s “talented tenth,” his social elitism separated him from the majority of black voters in West Virginia. ${ }^{5}$

Another reason was Clifford's age. In his mid-seventies, Clifford represented late nineteenth century and early twentieth century black politics, an era of conflict between two opposing political ideologies, accommodation versus integration, that had now come to an end. Instead, the N.A.A.C.P. provided a "middle ground” where blacks united in the fight against racial oppression; and although Clifford participated in the effort to unite African Americans in West Virginia with the establishment of the Civil Rights League, it was difficult, if not impossible, for him to accept the "separate but equal” institutions the League and the N.A.A.C.P., under the leadership of T.G. Nutter and Harry J. Capehart, embraced. ${ }^{6}$

As members of the state legislature, Nutter and Capehart, introduced numerous bills for the educational and social welfare of African Americans in the state between 1919 and 1921. As a result, the West Virginia Legislature officially passed a law establishing a State Supervisor of Negro Schools and a Negro Advisory Council to the State Board of Education in 1919. In addition, the legislature passed laws and provided funding for the West Virginia Colored Insane Asylum, the West Virginia Colored Deaf and Blind School, the State Industrial School for Colored Girls, the State Industrial School for Colored Boys, the State Colored Tuberculosis

\footnotetext{
${ }^{5}$ See Carter G. Woodson, “Early Black Education in West Virginia,” The Journal of Negro History, Vol. 8, No. 3 (July 1923): 338-345; and A.B. Caldwell, History of the American Negro: West Virginia Edition Vol. VII (Atlanta: A.B. Caldwell Publishing Co., 1923).

${ }^{6}$ Although blacks now agreed they must actively protest and fight for their civil and political rights and the N.A.A.C.P. remained a "protest" organization, William G. Jordan in Black Newspapers \& America's War for Democracy, 1914-1920 maintains these young African-American leaders, representatives of the "New Negro", mixed the political involvement and militant rhetoric of the radicals with the faith in economics and willingness for pragmatic compromise inherited from the conservatives. Like Booker T. Washington, the N.A.A.C.P. was backed by white philanthropists. In Negro Thought in America, August Meier also examines the blending of conservative and radical ideology of blacks following World War I. This "blending" is visible in N.A.A.C.P. leaders such as James Weldon Johnson who were influenced by Booker T. Washington's conservative ideology. See William G. Jordan, Black Newspapers \& America's War for Democracy, 1914-1920 (Chapel Hill: University of North Carolina Press, 2001), 27-28; August Meier, Negro Thought in America, 245-247, 256-278.
} 
Sanitarium, the State Home for Aged and Infirm Colored Men and Women, and the Bureau of Negro Welfare and Statistics. ${ }^{7}$ Through these institutions, black leaders in West Virginian "rejected the notion of segregation as a badge of black inferiority" and placed the welfare of African Americans, although state funded, under their management. In doing so, these black leaders accepted the constraints of segregation and worked within them to enforce a "separate but equal” policy; a policy the N.A.A.C.P. later employed to push the cost of segregation too high. ${ }^{8}$ Despite the benefits these institutions afforded to black institutions, the radical Clifford had difficulty accepting the conditions under which they existed. Indeed, his radical stance and calls for "independence" left him outside the non-political world of Carter G. Woodson and the "loyal" black Republicans found in A.B. Caldwell's History of the American Negro. Although Clifford was often more than willing to tout his own accomplishments, it is highly unlikely that he regretted his omission among, what he would have termed, the "sycophants" of the Republican Party.

Indeed, upon noticing Clifford's omission from Carter G. Woodson's article, John Cromwell immediately sent a note to Woodson listing some of Clifford's contributions to the race that resulted in correspondence between Clifford and Woodson. In February of 1923, when Clifford wrote a letter to Woodson praising him for his work and wishing Woodson an “abundance of success and a long life to open the world’s eyes to Negro history,” Clifford presented Woodson with a summary of his own history. Clifford also sent a copy of the journal containing Woodson's article to John Cromwell to deliver to Woodson; a copy that Clifford received from T. Edward Hill. When T. Edward Hill read the article, he sent the copy to Clifford

\footnotetext{
${ }^{7}$ Thomas E. Posey, The Negro Citizen of West Virginia (Institute, W.V.: Press of West Virginia State College, 1934), 55-62; Joe William Trotter, Coal, Class, and Color: Blacks in Southern West Virginia, 1915-1932 (Urbana: University of Illinois Press, 1990), 230.

${ }^{8}$ Posey, The Negro Citizen, 55-62; Trotter, Coal, Class, and Color, 230.
} 
with an inscription written on the book “in its presentation.” Apparently, Hill noted Clifford's dedication and work for African Americans in the state; and Clifford wanted Woodson to see it. At the end of the letter, Clifford wrote, “Now, Mr. Woodson, in the honor of a man, I don’t want a word, or any reference to anything I have said in this writing in your journal. Positively if you do, I’ll stop it; if you don't, I will help you.” Although Woodson honored Clifford’s request, he did publish a four page letter that John W. Cromwell sent to the Journal of Negro History in July of $1923 .^{9}$

Throughout the 1920s, Clifford remained actively involved in the American Negro Academy. Clifford, John W. Cromwell, and John E. Bruce desperately tried to find young responsible and effective leaders who could bring the Academy back to its former status and ensure its survival. Both felt, as Clifford wrote, "that Dr. Crummell’s plans and purposes” should for "his honor and sacred memory be carried out fully." In 1925, Clifford and Cromwell proposed the election of thirty-nine year old Alain Locke as president of the Academy, but failed. The Academy continued to decline until December of 1928 when academy members held the last known annual meeting. ${ }^{10}$

Perhaps one of the final blows to the American Negro Academy occurred in April of 1927 when Clifford's good friend John W. Cromwell passed away. Others who advocated radical protest quickly followed. T. Thomas Fortune died in 1928 followed by Clifford's fellow editor John Mitchell Jr., in 1929. On October 6, 1933, John Robert Clifford died of a cerebral hemorrhage at the age of eighty-five after falling down the stairs in his home. Initially buried at Martinsburg, West Virginia, Clifford was re-interned in Arlington Cemetery in 1954 at the

\footnotetext{
${ }^{9}$ Letter from J.R. Clifford to Carter G. Woodson, Library of Congress; “Communications,” Journal of Negro History, Vol. 8, No. 3 (July 1923): 338-341.

${ }^{10}$ Alfred A. Moss, The American Negro Academy: Voice of the Talented Tenth (Baton Rouge: Louisiana State University Press, 1981), 227, 230, 288; Stephen R. Fox, The Guardian of Boston: William Monroe Trotter (New
} 
request of his daughter Helen. William Monroe Trotter died six months later. ${ }^{11}$

While most histories claim that Booker T. Washington dominated black politics in West Virginia, it is also clear that Clifford and his Pioneer Press gave voice to the opposing ideologies of men such as John W. Cromwell, T. Thomas Fortune, Henry McNeal Turner, William Monroe Trotter, and W.E.B. DuBois; men Clifford was proud to call his friends and associates. Despite their political differences, Clifford was quick to offer support to these men. He was sympathetic to Fortune following a nervous breakdown and offered encouragement when he returned to the journalism world as the head of the editorial staff at the Washington Sun in 1914. When William Monroe Trotter fell ill from exhaustion and was hospitalized in 1916, it was J.R. Clifford and Harry C. Smith of the Cleveland Gazette who created a Trotter Press Testimonial Fund in an effort to provide financial support. ${ }^{12}$ These were the men who shared his dream for racial equality in America; these were the men that joined him in the fight for justice.

Principles and character guided the life of John Robert Clifford. They were essential to his concept of manhood, his social values, his spiritual beliefs, and his political ideology. Despite his criticism of the Republican Party, he remained, at heart, a Republican. His disillusionment with the Republican Party stemmed from anger, an emotion he shared with millions of other black Americans, at the party's failure to adhere to what he believed was its original principles. More importantly, he wanted the America people to have honor and patriotism enough to live up to the principles established in the Declaration of Independence and the American Constitution. Throughout his lifetime, Clifford expected and demanded all of the rights and privileges of an American citizen and, as a civil rights pioneer, he refused to settle for anything less.

York: Athenaeum, 1970), 211.

11 “J.R. Clifford, 85, Dies at Home Here,” Martinsburg Journal, October 6, 1933; Letter from Joseph F. Watt, Memorial Division, Department of the Army, to Helen C. Jackson, December 3, 1953, Paul I. and Margaret Washington Clifford Papers, Courtesy of Rosemary Clifford McDaniel. 
${ }^{12}$ Pioneer Press, September 19, 1914. 
"This is one vital truth that needs to be emphasized for the help and guidance of the race.

The final effect of our life, upon ourselves and on our race is what we are, not what we have.

Our real worth, in time as well as in eternity, is measured wholly by our character, not by our possessions." 


\section{BIBLIOGRAPHY}

Primary Sources:

$\underline{\text { Manuscripts }}$

Paul I. and Margaret Washington Clifford. Personal Collection. Atlanta, Georgia.

W.E.B. Du Bois Library. University of Massachusetts. Amhurst, Massachusetts.

W.E.B. DuBois Papers.

Library of Congress. Washington, D.C.

Department of Justice Files.

N.A.A.C.P. Records, West Virginia Branch Files.

Booker T. Washington Papers.

Carter G. Woodson Papers.

Rosemary Clifford McDaniel. Personal Collection. Fairfax Station, Virginia.

Moorland-Spingarn Research Center. Howard University. Washington, D.C.

Cromwell Family Papers.

Archibald Henry Grimke’ Papers.

Carter G. Woodson Papers

William R. Perkins Library. Duke University. Durham, North Carolina.

E.G. Buckles Diary

Charles James Faulkner, Sr. Papers.

William Henry Harrison Flick Papers.

Schomburg Center for Research in Black Culture, New York Public Library, New York, New York.

Proceedings of the National Convention of the Colored Men of America, held in Washington, D.C., on January 13, 14, 15, and 16, 1869. Washington, D.C.: Great Republic Book and Newspaper Printing Establishment, 1869. 
West Virginia and Regional History Collection. West Virginia

University. Morgantown, West Virginia.

George W. Atkinson Papers.

Justis Collins Papers.

John J. Cornwell Papers.

W.O. Dawson Papers.

William H.H. Flick Papers.

William E. Glasscock Papers.

Nathan Goff Papers.

Henry D. Hatfield Papers.

West Virginia Republican Party Papers.

W.V. Writers Program, W.P.A. Files.

Storer College Records.

A.B. White Papers.

\section{$\underline{\text { Public Documents }}$}

Berkeley County. John R. Clifford Indictments. Circuit Clerk's Office. Berkeley County Court House, Martinsburg, West Virginia.

Tucker County. Carrie Williams vs. Tucker County Board of Education, 1898. Circuit Clerk's Office. Tucker County Court House, Parsons, West Virginia.

United States. Bureau of the Census. Census of Population for 1880. National Archives Microfilm Publication (NAMP).

Census of Population for 1900. (NAMP).

House of Representatives. 62D Congress, 2d

Session, Report No. 1229. “Wiley v. Hughes,” August 1912.

West Virginia. West Virginia State Supreme Court of Appeals. 42 W.Va. 5-14-517 (1896) Martin v. Board of Education. Charleston, West Virginia. 
West Virginia State Supreme Court of Appeals. 45 W.Va. 194-203 (1898) Tucker v. Board of Education.

Charleston, West Virginia.

West Virginia State Supreme Court of Appeals. Reports of Cases Determined by the Supreme Court of Appeals Of West Virginia from February 15, 1906 to April 24, 1906. Vol. LIX. Morgantown: Acme Publishing Co., 1906.

\section{$\underline{\text { Newspapers }}$}

Baltimore American and Commercial Advertiser, 1874.

Berkeley Democrat, 1900.

Boston. The Guardian, 1904-1913.

Charleston Advocate, 1907-1912.

Charles Town Free Press, 1876.

Cleveland Gazette, 1883-1891.

Crisis, 1910-1913.

Martinsburg Era, 1871.

Martinsburg Herald 1887-1888.

Martinsburg Independent, 1881, 1884, 1886, 1888.

Martinsburg Evening Journal, 1917.

Martinsburg Journal, 1933.

Martinsburg Statesman, 1873-1874, 1904-1905.

McDowell Times, 1913-1917.

Morgantown Weekly Post, 1888, 1895.

People's Advocate, 1876-1886.

Pioneer Press, 1885-1888, 1908, 1911-1917. 
Pittsburgh Courier, 1912.

Richmond Planet, 1898-1906.

Spirit of Jefferson, 1868, 1871.

Storer Record, 1901, 1904, 1905.

Virginia Free Press, 1867, 1870.

Wheeling Daily Intelligencer, 1869-1870, 1900.

Wheeling Register, 1888, 1892, 1900.

\section{Pamphlets}

American Negro Labor Congress. "Program of the American Negro Labor Congress, Champion of the Rights of the 12,000,000 Oppressed Negroes in the United States.” New York: American Negro Labor Congress, 192?.

Clarke, T.H.R. and B. McKay, editors. "A Republican Text-Book For Colored Voters," 1901 ?. Daniel A.P. Murray Collection, Library of Congress, Washington, D.C.

Dawson, William. "The Republican Party," 1904. WVRHC.

Davis, John J. "Why we are Democrats and What We Believe," 1904. WVRHC.

"A.B. Fleming vs. Nathan Goff Contest Depositions, Mercer and McDowell Counties," 1889. WVRHC.

Davis, John W. Negro Club. "The New Negro," 192(?). WVRHC.

Duker, John. "Advice to the Colored Voters of the United States," c. Aug. 1896. Daniel A.P. Murray Collection, Library of Congress, Washington, D.C.

Elkins, Stephen B. "An Address Before the Literary Societies of West Virginia," 1888. WVRHC.

Green, John P. "Colored men and the Democratic Party: Review of American History on this Issue," 1901. Daniel A.P. Murray Collection, Library of Congress, Washington, D.C.

Lynch, John R. "Colored Americans: John R. Lynch's Appeal to Them," 1900? Daniel A.P. Murray Collection, Library of Congress, Washington, D.C. 
MacCorkle, William A. "The Negro and the Intelligence and Property Franchise.” Address before the Southern Conference on Race Problems, Montgomery, Alabama, May 9, 1900.

African American Pamphlet Collection, Library Of Congress, Washington, D.C.

Roosevelt, Theodore. "The Negro Question: Attitude of the Progressive Party Toward the Colored Race.” New York, N.Y.: Stoddard-Sutherland Press, 1912.

Shaw, Daniel W. "An Address to the Negro Voters of West Virginia," 1900. Union Theological Seminary, New York.

"The State Journal-County Republican Club of West Virginia, 1896." WVRHC.

$\underline{\text { Books }}$

Aler, F. Vernon. Aler's History of Martinsburg and Berkeley Co., West Virginia. Hagerstown, Md.: The Mail Publishing Co., 1888.

Arter, Jared M. Echoes From a Pioneer Life. Atlanta, Ga.: A.B. Caldwell Publishing, Co., 1922. Brown, J.L. Ritual of the Knights of Wise Men: Initiatory, First, Second and Third Degree Composed of Rules, Laws, and Regulations Relating to the Election, Obligation and Institution. Nashville, Tenn.: Printed by J.L. Brown, 1881.

Caldwell, A.B., ed. History of the American Negro: West Virginia Edition. Vol. VII. Atlanta, Ga.: A.B. Caldwell Publishing Company, 1923.

Cross, Samuel Creed. The Negro and the Sunny South: A Lecture. Martinsburg, WV: S.C. Cross Publisher, 1899.

Department of Commerce. Negro Population in the United States, 1790-1915. New York: Arno Press, 1968. (Original, Washington, D.C.: Government Printing Office, 1918.

DuBois, W.E.B. The Souls of Black Folk. Boston, Mass.: Bedford Books, 1997. (1903)

Gibbs, Mifflin Wistar. Shadow and Light. Washington, D.C.: M.W. Gibbs, 1902.

Green, John P. Fact Stranger Than Fiction: Seventy-five Years Of a Busy Life with Reminiscences of Many Great and Good Men and Women. Cleveland, Ohio: Riehl Printing Company, 1920.

McGhee, Edward A. Illustrated Story of Beautiful Kanawha Valley. 1923.

Simmons, William J. Men of Mark: Eminent, Progressive and Rising. Cleveland, Ohio: George M. Powell \& Co., 1887. 
Summers, Festus. The Baltimore and Ohio in the Civil War. New York: G.P. Putnam’s Sons, 1939.

Washington, Booker T. Up From Slavery. New York, N.Y.: Prestige Books, Inc., 1968. Original 1901.

Woodson, Carter G. History of the Negro Church. Washington, D.C.: Associated Publishers, 1921.

Woodson, Carter G. The Negro Professional Man and the Community with Special Emphasis on the Physician and the Lawyer. New York: Negro Universities Press, 1934.

\section{Articles}

Barber, J. Max. "The Niagara Movement at Harpers Ferry." Vol. 3, No. 10 (October 1906): 402411.

Cromwell, John W. Letter to the editor in "Communications." Journal of Negro History XIII, No. 3 (July 1923): 338.

DuBois, W.E.B. "The Growth of the Niagara Movement." The Voice of the Negro Vol. 3 (January 1906): 43-45.

DuBois, W.E.B. "The Niagara Movement." The Voice of the Negro Vol. 2, No. 9 (September 1905): 619-622.

"In the Sanctum." The Voice of the Negro Vol. 2, No. 9 (September 1905): 647-648.

Miller, Kelly. "The Negro as a Political Factor." The Voice of the Negro. Vol. 1, No. 2 (February 1904): 17-22 and 57-64.

"Our Monthly Review." The Voice of the Negro Vol. 1, No. 9 (September 1904): 365-376.

"Our Monthly Review," Voice of the Negro Vol. 2 No. 9 (Sept. 1905): 600-604.

Rucker, Henry A. "Why Colored Men Cannot be Democrats." The Voice of the Negro Vol. 1, No. 9 (September 1904): 382-390.

Scarborough, W.S. "The Negro's Duty in the Present Contest." The Voice of the Negro Vol. 1, No. 11 (November 1904): 531-533.

The Significance of the Niagara Movement in "Our Monthy Review." The Voice of the Negro Vol. 2, No. 9 (September 1905): 600-604.

White, George H. "The Injustice to the Colored Voter." Independent 52 (Jan. 1900): 176-77. 
Secondary Sources:

$\underline{\text { Books }}$

Alexander, Ann Field. Race Man: The Rise and Fall of the "Fighting Editor,” John Mitchell, Jr. Charlottesville: University of Virginia Press, 2002.

Angell, Stephen Ward. Bishop Henry McNeal Turner and African-American Religion in the South. Knoxville, Tenn.: The University of Tennessee Press, 1992.

Aptheker, Herbert. W.E.B. DuBois: The Correspondence of W.E.B. DuBois, Vol. 1 Selections, 1877-1934. Amherst: University Of Massachusetts Press, 1973.

Asklar, Eugene John. The Niagara Movement: Birth of Negro Militancy. New York:

Niagara University, 1966.

Astor, Gerald. The Right to Fight: A History of African Americans in the Military. Cambridge, Ma.: De Capo Press, 1998.

Ayers, Edward L. The Promise of the New South: Life After Reconstruction. New York, N.Y.: Oxford University Press, 1992.

Beatty, Bess. A Revolution Gone Backward: The Black Response to National Politics, 18761896. New York: Greenwood Press, 1987.

Bruce, Dickson D., Jr. Archibald Grimke’: Portrait of a Black Independent. Baton Rouge: Louisiana State University Press, 1993.

Brundage, W. Fitzhugh. Lynching in the New South: Georgia and Virginia, 1880-1930. Urbana: University of Illinois Press, 1993.

Burkel, Nicholas. Progressive Governors in the Border States: Reform Governors of Mississippi, Kentucky, West Virginia, and Maryland, 1900-1918. 1971.

Burrows, John H. The Necessity of Myth: A History of the National Negro Business League, 1900-1945. Auburn, Ala.: Hickory Hill Press, 1988.

Bushong, Millard K. Historic Jefferson County. Boyce, Va.: Carr Publishing Company, Inc., 1972.

Callcott, Margaret Law. The Negro in Maryland Politics, 1870-1912. Baltimore: John Hopkins University Press, 1969.

Cartwright, Joseph H. The Triumph of Jim Crow: Tennessee RaceRelations in the 1880s. 
Knoxville: University of Tennessee Press, 1976.

Casdorph, Paul. Republicans, Negroes, and Progressives in the South, 1912-1916. Ala.: University of Alabama Press, 1981.

Childs, John Brown. The Political Black Minister: A Study in_Afro-American Politics and Religion. Boston, Mass.: G.K. Hall, 1980.

Clements, Kendrick A. Woodrow Wilson: World Statesman. Boston: G.K. Hall \& Co., 1987.

Comstock, Jim, ed. The West Virginia Heritage Encyclopedia Vols. 1-5. Richwood, W.Va., 1976. Urbana, Ill.: University of Illinois Press, 1981.

Couto, Richard A. Lifting the Veil: A Political History of Struggles for Emancipation. Knoxville, Tenn.: University of Tennessee Press, 1993.

Dailey, Jane. Before Jim Crow: The Politics of Race in Post-Emancipation Virginia. Chapel Hill, N.C.: University of North Carolina Press, 2000.

Dailey, Jane; Gilmore, Glenda Elizabeth; and Simon, Bryant, eds. Jumpin’ Jim Crow: Southern Politics from the Civil War to Civil Rights. Princeton: Princeton University Press, 2000.

Dunn, Martin E. The Black Press, 1827-1890: The Quest for National Identity. New York: G.P. Putnam's Sons, 1971.

Dawson, Michael C. Behind the Mule: Race and Class in African-Politics. Princeton, N.J.: Princeton University Press, 1995.

Diner, Steven J. A Very Different Age: American of the Progressive Era. New York: Hill and Wang, 1998.

Evans, Willis F. History of Berkeley County West Virginia. Martinsburg, W.Va.: Willis F. Evans, 1928.

Fairclough, Adam. Better Day Coming: The Black Struggle for Equalit: Blacks and Equality, 1890-2000. New York: Viking Press, 2001.

Fenton, John H. Politics in the Border States: A Study of the Patterns of Political Organizations and Political Change, Common to the Border States-Maryland, West Virginia, Kentucky, and Missouri. New Orleans, La.: Balleon Books, 1957.

Finkleman, Paul, ed. African Americans and the Legal Profession in Historical Perspective (Race, Law, and American History, 1700-1900: The African American Experience, Vol.10). New York: Garland Publishing, Inc., 1992.

Finkleman, Paul, ed. The Struggle for Equal Education: Race, Law, and American History, 
1700-1900: The African American Experience, Vol. 7. New York: Garland Publishing Inc., 1992.

Foner, Eric. Reconstruction: America's Unfinished Revolution 1863-1877. New York: Harper \& Row, 1988.

Philip S. Foner and George E. Walker, eds., Proceedings of the Black National and State Conventions, 1865-1900. Philadelphia: Temple University Press, 1986.

Fox, Stephen R. The Guardian of Boston: William Monroe Trotter. New York: Atheneum, 1970.

Frankel, Noralee and Dye, Nancy S., editors. Gender, Class, Race and Reform in the Progressive Era. Lexington, Ky.: University of Kentucky Press, 1991.

Frankel, Noralee. Break Those Chains at Last: African Americans 1860-1880. Oxford: Oxford University Press, 1996.

Franklin, John Hope and Meier, August, eds. Black Leaders of the Twentieth Century. Urbana and Chicago, Ill.: University of Illinois Press, 1982.

Franklin, John Hope and Moss, Alfred, A. From Slavery to Freedom: A History of African Americans. New York, N.Y.: McGraw Hill, Inc., 1994.

Gatewood, Willard B. Aristocrats of Color: The Black Elite, 1880-1920. Bloomington, Ind.: Indiana University Press, 1990.

Geffert, Hannah N. An Annotated Narrative of the African-American Community in Jefferson County, West Virginia. 1991.

Gerber, David A. Black Ohio and the Color Line 1860-1915. Urbana: University of Illinois Press, 1976.

Grantham, Dewey W. Southern Progressivism: The Reconciliation_of Progress and Tradition. Knoxville, Tenn.: University of Tennessee Press, 1983.

Grossman, Lawrence. The Democratic Party and the Negro: Northern and National Politics, 1868-92. Urbana: University of Illinois Press, 1976.

Hackley-Lambert Anita. F.H.M. Murray: First Biography of a Forgotten Pioneer for Civil Justice. Charleston, S.C.: BookSurge Publishing, 2006.

Hahn, Steven. A Nation Under Our Feet: Black Political Struggles in the Rural South from Slavery to the Great Migration. Cambridge: Harvard University Press, 2003.

Hale, Grace Elizabeth. Making Whiteness: The Culture of Segregation In the South, 1890-1940. 
New York: Vintage Books, 1998.

Harlan, Louis. Booker T. Washington: The Making of a Black Leader, 1856-1901. London: Oxford University Press, 1972.

Harvey, Paul. Redeeming the South: Religious Cultures and Racial Identities Among Southern Baptists 1865-1925. Chapel Hill, N.C.: University of North Carolina Press, 1997.

Hirshon, Stanley. Farewell to the Bloody Shirt: Northern Republicans and the Southern Negro, 1877-1893. Bloomington, Ind.: Indiana University Press, 1962.

Jackson, Luther Porter. Free Negro Labor and Property Holding in Virginia, 1830-1860. New York: D. Appleton-Century Company, 1942.

James, Joy. Transcending the Talented Tenth: Black Leaders and American Intellectuals. New York: Routledge, 1997.

Jordon, William G. Black Newspapers \& America’s War for Democracy, 1914-1920. Chapel Hill: University of North Carolina Press, 2001.

Katz, William Loren, ed. Proceedings of the National Negro Conference, 1909. New York: Arno Press and the New York Times, 1969.

Kornweibel, Theodore, Jr., Ed. Federal Surveillance of Afro-Americans, (1917-1925): the First World War, the Red Scare, and the Garvey Movement. Fredrick, Md.: University Publications of America, c. 1985.

Kornweibel, Theodore, Jr. “Seeing Red”: Federal Campaigns Against Black Militancy, 19191925. Bloomington and Indianapolis: Indiana University Press, 1998.

Lewis, David Levering. W.E.B. DuBois: Biography of a Race, 1868-1919. New York: Henry Holt \& Company, 1993.

Lewis, Ronald L. Transforming the Appalachian Countryside: Railroads, Deforestation, and Social Change in West Virginia, 1880-1920. Chapel Hill, N.C.: University of North Carolina Press, 1998.

Lewis, Stephen Johnson. Undaunted Faith: The Life Story of Jennie Dean. Manassas, Va.: Manassas Museum, 1994. Original published 1942 by the Circuit Press in Catlett, Va. Autobiography.

Lincoln, C. Eric and Mamiya, Lawrence H. The Black Church in the_African American Experience. Durham, N.C.: Duke University Press, 1990.

Link, William A. The Paradox of Southern Progressivism, 1880-1930. Chapel Hill, N.C.: University of North Carolina Press, 1992. 
Logan, Rayford Whittingham. The Betrayal of the Negro: From Rutherford Hayes to Woodrow Wilson. DaCapo Press, 1997.

McKinney, Gordon B. Southern Mountain Republicans 1865-1900. Knoxville, Tenn.: The University of Tennessee Press, 1998.

Meier, August. Negro Thought in America, 1880-1915: Racial Ideologies in the Age of Booker T. Washington. Ann Arbor, Mich.: University of Michigan Press, 1963.

Moon, Henry Lee. Balance of Power: The Negro Vote. Garden City, N.Y.: Doubleday, 1948.

Moore, Jacqueline M. Leading the Race: The Transformation of The Black Elite in the Nation's Capital, 1880-1920. Charlottesville: University Press of Virginia, 1999.

Morris, Milton D. The Politics of Black America. New York: Harper \& Row, 1975.

Moss, Alfred. The American Negro Academy: Voice of the Talented Tenth. Baton Rouge, La.: Louisiana State University Press, 1981.

Nelson, Paul D. Fredrick L. McGhee: A Life on the Color Line, 1861-1912. St. Paul: Minnesota Historical Society Press, 2002.

Nieman, Donald, ed. African Americans and Southern Politics From Redemption to Disfranchisement. New York: Garland Publishing, Inc., 1994.

Nieman, Donald, ed. Black Southerners and the Law 1865-1900. New York: Garland Publishing, Inc., 1994.

O’Grady, R.P. Chicago and Cook County Official Republican Directory and Sketch Book, 1900, Chicago, Ill., 1900.

Painter, Nell Irvin. Standing at Armageddon: The United States, 1877-1919. New York: W.W. Norton \& Company, 1987.

Patler, Nicholas. Jim Crow and the Wilson Administration: Protesting Federal Segregation In the Early Twentieth Century. Boulder: University Press of Colorado, 2004.

Perman, Michael. Struggle for Mastery: Disfranchisement in the South, 1888-1908. Chapel Hill: University of North Carolina Press, 2001.

Peters, R. Worth. Secondary Education in Manassas, Virginia, 1890-1930. 1935.

Posey, Thomas E. The Negro Citizen of West Virginia. Institute, W.Va.: Press of West Virginia State College, 1934. 
Rudwick, Elliott M. Propagandist of the Negro Protest. New York: Atheneum, 1969.

Schneider, Mark R. Boston Confronts Jim Crow, 1890-1920. Boston: Northeastern University Press, 1997.

Schneider, Mark Robert. “We Return Fighting”: The Civil Rights Movement in the Jazz Age. Boston: Northwestern University Press, 2002.

Sherman, Richard B. The Republican Party and Black America from McKinley to Hoover, 18961933. Charlottesville: University Press of Virginia, 1973.

Smith, J. Clay, Jr. Emancipation: The Making of the Black Lawyer, 1844-1944. Philadelphia: University of Pennsylvania Press, 1993.

Taylor, James L. A History of Black Education in Jefferson County, West Virginia, 1866-1966.

Trotter, Joe W., Jr. Coal, Class and Color: Blacks in Southern West Virginia 1915-32. Urbana, Ill.: University of Illinois Press, 1991.

Trotter, Joe William, Jr. and Bickley, Ancella Radford. Honoring Our Past: Proceedings of the First Two Conferences on West Virginia's Black History.

Upchurch, Thomas Adams. Legislating Racism: The Billion Dollar Congress and the Birth of Jim Crow. Lexington: University Press of Kentucky, 2004.

Walton, Hanes Jr. Black Politics: A Theoretical and Structural Anaylsis. Philadelphia, Pa.: J.B. Lippincott Company, 1972.

Walton, Hanes Jr. Black Republicans: The Politics of the Black and Tans. Metuchen, N.J.: Scarecrow Press, Inc., 1975.

Weiner, Mark S. Black Trials: Citizenship from the Beginnings of Slavery to the End of Caste. New York: Alfred A. Knopf, 2004.

Williams, John Alexander. West Virginia and the Captains of Industry. Morgantown, W.Va.: West Virginia University Foundation, 1976.

Williamson, Joel. A Rage for Order: Black-White Relations in The American South Since Emancipation. New York: Oxford University Press, 1986.

Woodward, C. Vann. Origins of the New South 1877-1913. Louisiana State University Press, 1951, 1971.

Woodward, C. Vann. The Strange Career of Jim Crow. New York: Oxford University Press, 1957. 


\section{$\underline{\text { Articles }}$}

Alexander, Raymond Pace. "The Upgrading of the Negro's Status By Supreme Court Decisions," Journal of Negro History Vol. 30 No. 2 (April 1945): 117-149.

Beatty, Bess. "Black Newspapers: Neglected Source for the 'New South'," Negro History Bulletin Vol. 43 No. 3 (July/August 1980): 60-62.

Berardi, Gayle K. and Segady, Thomas W. "The Development of African-American Newspapers in the American West: A Socio-Historical Perspective," Journal of Negro History Vol. 75 Nos. 3-4 (Summer/Fall 1990): 98-109.

Brier, Stephen. "Interracial Organizing in the West Virginia Coal Industry: The Participation of Black Mine Workers In the Knights of Labor and the United Mine Workers, 1880-1894,” in Essays in Southern Labor History.

DeSantis, Vincent P. "Negro Dissatisfaction with Republican Policy in the South, 1882-1884." Journal of Negro History XXXVI, No. 2 (April 1951): 148-159.

DeSantis, Vincent P. "President Arthur and the Independent Movements in the South in 1882," Journal of Southern History Vol. No. ( ): 346-363.

DeSantis, Vincent P. "The Republican Party and the Southern Negro, 1877-1897." Journal of Negro History XLV No.2 (April 1960): 71-87.

Domke, David. "The Black Press in the 'Nadir' of African Americans," Journalism History Vol. 20 No. 3-4 (Autumn/Winter 1994): 131-138.

Ellis, Mark. "America's Black Press, 1914-18," History Today Vol. 41 (September 1991): 20-27.

Engle, Stephen D. "Mountaineer Reconstruction: Blacks in the Political Reconstruction of West Virginia." Journal of Negro History LXXVIII, No. 3 (Summer, 1993): 137-163.

Fultz, Michael. “'The Morning Cometh': African-American Periodicals, Education, and the Black Middle Class, 1900-1930,” Journal of Negro History Vol. 80, No. 3 (Summer, 1995): 97-112.

Goldstein, Michael L. "Preface to the Rise of Booker T. Washington: A View from New York City of the Demise of Independent Black Politics, 1889-1902,” Journal of Negro History Vol. 62, No. 1 (Jan., 1977): 81-99.

James, Felix. “The Civic and Political Activities of George A. Myers,” Journal of Negro History Vol. 58, No. 2 (Apr., 1973): 166-178.

Jones, Lester M. "The Editorial Policy of Negro Newspapers of 1917-1919 as Compared with 
That of 1941-42," Journal of Negro History Vol. 29 No. 1 (January 1944): 24-31.

Jordon, William. "'The Damnable Dilemma': African-American Accomodation and Protest During World War I,” Journal Of American History Vol. 81, No. 4 (Mar., 1995): 15621583.

Kelly, Brian. "Beyond the 'Talented Tenth': Black Elites, Black Workers and the Limits of Accommodation in Industrial Birmingham, 1900-1921" in Adam Green and Charles Payne, Time Longer Than Rope: Civil Rights before the Civil Rights Movement. New York: New York University Press, 2003.

Kelly, Brian. "Sentinels for New South Industry: Booker T. Washington, Industrial Accommodation \& the Black Working Class under Jim Crow" in Eric Arnesen, eds. Black Labor and the Fight for Equality. Urbana: University of Illinois Press, 2003.

Kolchin, Peter. "Scalawags, Carpetbaggers, and Reconstruction: A Quantitative Look at Southern Congressional Politics, 1868-1872," The Journal of Southern History Vol. XLV, No.1 (February 1979): 63-76.

Little, Lawrence S. "The African Methodist Episcopal Church Media and Racial Discourse, 1880-1900,” The North Star Vol. 2, No. 1 (Fall 1998).

Link, Arthur S. "The Negro as a Factor in the Campaign of 1912," Journal of Negro History Vol. 32 No. 1 (Jan. 1947): 81-98.

Lunardini, Christine A. "Standing Firm: William Monroe Trotter’s Meetings With Woodrow Wilson, 1913-1914,” Journal of Negro History Vol. 64, No. 3 (Summer, 1979): 244-264.

Johnson, Abby Arthur and Johnson, Ronald M. "Away From Accommodation: Radical Editors and Protest Journalism, 1900-1910." Journal of Negro History LXII, No. 4 325-338.

Jordon, William. “'The Damnable Dilemma': African-American Accommodation and Protest during World War I.” Journal Of American History 81, No. 4 (Mar., 1995): 1562-1583.

McKinney, Gordon. "Southern Mountain Republicans and the Negro, 1865-1900." Journal of Southern History 41 (Nov. 1975): 493-516.

Meier, August. "The Negro and the Democratic Party, 1875-1915." Phylon XVII No. 2 (2nd Quarter, 1956): 173-91.

Miller, Sally M. “The Socialist and the Negro, 1901-20,” Journal of Negro History Vol. 56, No. 3 (Jul., 1971): 220-229.

Rudwick, Elliott M. "The Niagara Movement." Journal of Negro History Vol. 42 No. 3 (July 1957): 177-200. 
Schneider, Mark R. “The Colored American and Alexander’s: Boston’s Pro-Civil Rights Bookerites,” Journal of Negro History Vol. 80, No. 4 (Autumn, 1995): 157-169.

Scott, Anne Firor. “Most Invisible of All: Black Women’s Voluntary Associations.” The Journal of Southern History 56 (Feb., 1990): 3-22.

Tucker, Gary J. “William E. Glasscock and the West Virginia Election of 1910.” West Virginia History XL, No. 3 (Spring, 1979): 254-267.

VanDeusen, John G. "The Negro in Politics.” The Journal of Negro History XXI, No. 3 (July 1936): 256-274.

Woods, Randall B. "C.H.J. Taylor and the Movement for Black Political Independence, 1882-1896." Journal of Negro History LXVII, No. 2 (Summer 1982): 122-135.

\section{$\underline{\text { Dissertations }}$}

Alexander, Shawn Leigh. “'We Know Our Rights and Have the Courage To Defend Them': The Spirit of Agitation in the Age of Accommodation, 1883-1909.” Ph.D. dissertation, 2004.

Burke, Dawne Raines. "Storer College: A Hope for Redemption in the Shadow of Slavery, 1865-1955.” Ph.D. dissertation, Virginia Polytechnic Institute \& State University, 2004.

Cripps, Thomas. "The Lily White Republicans, the Negro, the Party, and the South in the Progressive Era." Ph.D. dissertation, University of Maryland, 1967.

Duncan, Hannibal Gerald. "The Changing Race Relationship in The Border and Northern States.” Ph.D. dissertation, University of Pennsylvania, 1922.

Murray, Percy Edward. "Harry Clay Smith, Black Journalist and Legislator.” Ph.D. dissertation, Miami University, 1977.

Sheeler, John Reuben. "The Negro In West Virginia Before 1900." Ph.D. dissertation, West Virginia University, 1954.

Smith, Gerald Wayne. "Nathan Goff, Jr.: A Biography." Ph.D. dissertation, West Virginia University, 1954.

Tucker, Gary Jackson. "William E. Glasscock, Thirteenth Governor of West Virginia.” Ph.D. dissertation, West Virginia University, 1978. 
Theses

Easton,, Charles Edward. "Negro Contributions to the Political and Legal History of the Southern Counties of West Virginia." Master's thesis, Marshall University, 1964.

Ferrell, Barbara Ann. "West Virginia and the Election of 1896." Master's thesis, West Virginia University, 1967.

Jacobs, James Henry. "The West Virginia Gubernatorial Election Contest." Master's thesis, West Virginia University, 1942.

Jones, Lawrence N. "The Civil Status of Negroes in West Virginia as Reflected in Legislative Acts and Judicial Decisions, 1860-1940.” Master’s thesis, University of Chicago, 1948.

Talbott, Forrest, "Some Legislative and Legal Aspects of the Negro Question in West Virginia," Master's thesis, University of Minnesota, 1942.

Wynne, Ann Marie. “Reconstruction and the Negro in West Virginia.” Master's thesis, University of Maryland, 1972. 


\section{APPENDIX I}

\begin{tabular}{|c|c|c|c|}
\hline \multicolumn{4}{|c|}{ Soldiers of the $13^{\text {th }}$ U.S. Heavy Artillery, Company $F$} \\
\hline 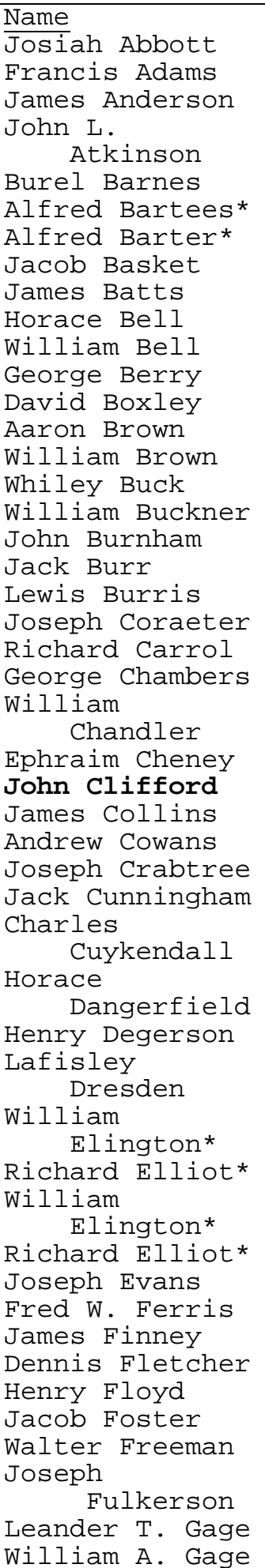 & $\begin{array}{l}\text { Rank } \\
\text { Asst. Surgeon } \\
\text { Sergeant/Major } \\
\text { Private } \\
\text { Private } \\
\text { Private } \\
\text { Private } \\
\\
\text { Private } \\
\text { Private } \\
\text { Private } \\
\text { Private } \\
\text { Private } \\
\text { Private } \\
\text { Private } \\
\text { Private } \\
\text { Private/Corporal } \\
\text { Private/Corporal } \\
\text { Private } \\
\text { Private } \\
\text { Private } \\
\text { Private/Sergeant } \\
\text { Private/Corporal } \\
\text { Private/Musician } \\
\text { Private } \\
\text { Private/Corporal } \\
\text { Private/Corporal } \\
\text { Private } \\
\text { Private } \\
\text { Private } \\
\text { Captain } \\
\text { Private/Sergeant } \\
\text { Private } \\
\text { Private } \\
\text { Private } \\
\text { Private } \\
\text { Private } \\
\text { Quartermaster/Sergeant } \\
\text { Major } \\
\text { Private } \\
\text { Private } \\
\text { Surgeon } \\
\text { Private } \\
\text { Private/Sergeant } \\
\text { Private } \\
\text { Pate } \\
\text { Private }\end{array}$ & $\begin{array}{l}\frac{\text { Name }}{\text { James Gates }} \\
\text { Washington } \\
\text { George } \\
\text { Francis H. } \\
\text { Golden } \\
\text { Andrew Grafton } \\
\text { Peter Gray* } \\
\text { Edner Green } \\
\text { Thomas Green } \\
\text { Peter Grey* } \\
\text { George Griffin } \\
\text { Calvin Hackley } \\
\text { Milton Harley } \\
\text { Clark Harrison } \\
\text { Henry Hastings } \\
\text { James F. Hay } \\
\text { Peter . } \\
\text { Hickenbotham } \\
\text { Colonel Hicks } \\
\text { Henry Higgins } \\
\text { Gamaliel G. } \\
\text { Hill } \\
\text { Richard Hill } \\
\text { Thomas Hodge } \\
\text { Charles Hoper } \\
\text { Leroy Howard } \\
\text { Theodore } \\
\text { Hubbard } \\
\text { William H. Hunt } \\
\text { Daniel Isard** } \\
\text { Daniel Izard* } \\
\text { James Jackson } \\
\text { Jeffers Jackson } \\
\text { John Jackson } \\
\text { Thomas } \\
\text { Jefferson } \\
\text { Douglas Johnson } \\
\text { Elijah Johnson } \\
\text { George W. } \\
\text { William Johnson } \\
\text { Charles Jones } \\
\text { Squire Jones } \\
\text { Wiley Jordon } \\
\text { Samuel Kenley } \\
\text { Aberdeen } \\
\text { Thomas Lecounts Lewis } \\
\text { Lilly Lilburn } \\
\text { Charles Locket } \\
\text { Joseph Logan } \\
\text { Henry Long } \\
\text { John Lucas } \\
\text { Moses Marks } \\
\text { Jesse Martin } \\
\text { Levin Mitchell }\end{array}$ & $\begin{array}{l}\text { Rank } \\
\text { Private } \\
\text { Corporal } \\
\text { Private } \\
\text { Private } \\
\text { Private } \\
\text { Private } \\
\text { Private } \\
\text { Private } \\
\text { Private } \\
\text { Private/Sergeant } \\
\text { Private } \\
\text { Private } \\
\text { Bugler } \\
\text { Private } \\
\text { Private } \\
\text { Private } \\
\text { Private } \\
\text { Sergeant } \\
\text { Private } \\
\text { Private } \\
\text { Private } \\
\text { 1 st Lieutenant } \\
\text { Sergeant } \\
\text { Corporal } \\
\text { Private } \\
\text { Private } \\
\text { Private } \\
\text { Private } \\
\text { Private } \\
\text { Private } \\
\text { Private } \\
\text { Private } \\
\text { Private } \\
\text { Chaplain } \\
\text { Private } \\
\text { Private/Corporal } \\
\text { Private } \\
\text { Private } \\
\text { Private } \\
\text { Private/Artificer } \\
\text { Private/Sergeant } \\
\text { Private } \\
\text { Private } \\
\text { Private } \\
\text { Private } \\
\text { Private } \\
\text { Private/Corporal } \\
\text { Private } \\
\text { Private }\end{array}$ \\
\hline
\end{tabular}




\begin{tabular}{|c|c|c|c|}
\hline $\begin{array}{l}\text { Daniel Murray } \\
\text { Toney New } \\
\text { Alfred Noble } \\
\text { Lewis Oglesby } \\
\text { Alfred Osborn } \\
\text { Simon Pabud } \\
\text { George W. } \\
\text { Palmer } \\
\text { Daniel Parker } \\
\text { George Parker } \\
\text { Samuel Parker } \\
\text { Edmond Parris } \\
\text { Nelson Peveler } \\
\text { Green Philips } \\
\text { William W. } \\
\text { Piper } \\
\text { Gorham Powers } \\
\text { John Quinn } \\
\text { John W. Ramsey } \\
\text { John Randall } \\
\text { Jacob Ray } \\
\text { Peter Ray } \\
\text { John Reed } \\
\text { Frank S. } \\
\text { Richmond } \\
\text { Alexander } \\
\text { Roberts } \\
\text { Captain } \\
\text { Robinson } \\
\text { George Robinson } \\
\text { Booker Rowley } \\
\text { William } \\
\text { Jacob Schooner } \\
\text { John Scott } \\
\text { John Sheets } \\
\text { Wesley Sheets } \\
\text { Eli Shepard } \\
\text { Joseph Sherman } \\
\text { Levi Shotridge } \\
\text { Solomon Simons } \\
\text { John Sims } \\
\text { Kirk Simond } \\
\text { Robert Simpson } \\
\text { Granville Sims } \\
\text { Moses Smiley } \\
\text { Howard E. Smith } \\
\text { Jacob Smith } \\
\text { John Smith } \\
\text { Samuel Smith } \\
\text { James Souns } \\
\text { Green Spide } \\
\text { Augustus } \\
\text { Sagtewart }\end{array}$ & $\begin{array}{l}\text { Private } \\
\text { Private } \\
\text { Private } \\
\text { Private } \\
\text { Private } \\
\text { Private } \\
\text { Private } \\
\text { Private } \\
\text { Lieutenant/Colonel } \\
\text { Private } \\
\text { Private } \\
\text { Private } \\
\text { Private } \\
\text { Assistant Surgeon } \\
\text { 2nd Lieutenant } \\
\text { Private } \\
\text { Private } \\
\text { Private } \\
\text { Private/Corporal } \\
\text { Private } \\
\text { Private } \\
\text { 2 }{ }^{\text {nd Lieutenant }} \\
\text { Private } \\
\text { Private } \\
\text { Private } \\
\text { Private } \\
\text { Private } \\
\text { Private } \\
\text { Private } \\
\text { Private } \\
\text { Private } \\
\text { Private } \\
\text { Private } \\
\text { Corporal } \\
\text { Private } \\
\text { Private } \\
\text { Private } \\
\text { Private } \\
\text { Private } \\
\text { Major } \\
\text { Private } \\
\text { Private } \\
\text { Private } \\
\text { Private } \\
\text { Private } \\
\text { Private }\end{array}$ & $\begin{array}{l}\text { John Stith } \\
\text { Randall Stone } \\
\text { Wesley Strond } \\
\text { Edmond Sugg } \\
\text { Zachariah } \\
\text { Taylor } \\
\text { William Thomas } \\
\text { Benjamin Towers } \\
\text { James Towns } \\
\text { Zachariah } \\
\text { Turner } \\
\text { Cornelius C. } \\
\text { Vaughn } \\
\text { George Vessey } \\
\text { Louis Vinson } \\
\text { William Vond } \\
\text { Stephen Wadkins } \\
\text { Lisbon Walker } \\
\text { William Wallace } \\
\text { Charles S. Warn } \\
\text { Richard Washam } \\
\text { George } \\
\text { Washington } \\
\text { George } \\
\text { Washington } \\
\text { George } \\
\text { Washington } \\
\text { George } \\
\text { Washington } \\
\text { George } \\
\text { Washington } \\
\text { George } \\
\text { Washington } \\
\text { Charles Weaver } \\
\text { Bob White } \\
\text { George White } \\
\text { Samuel Wilkinson } \\
\text { George Williams } \\
\text { George Williams } \\
\text { John Williams } \\
\text { Oliver } \\
\text { Williamson } \\
\text { George Willis } \\
\text { Jacob Wilson } \\
\text { Jacob Wilson } \\
\text { Joseph Wilson } \\
\text { William Wilson } \\
\text { Alexander } \\
\text { Wiseman } \\
\text { George M. Works } \\
\text { Anthony Yaubrey } \\
\text { Greer Young } \\
\text { Ger }\end{array}$ & $\begin{array}{l}\text { Private } \\
\text { Private } \\
\text { Private } \\
\text { Private } \\
\text { Private } \\
\text { Private } \\
\text { Private/Corporal } \\
\text { Private } \\
\text { Private } \\
\text { Private/Sergeant } \\
\text { Corporal } \\
\text { Private } \\
\text { Private } \\
\text { Private } \\
\text { Private } \\
\text { 1 st Lieutenant } \\
\text { Private } \\
\text { Private } \\
\text { Private } \\
\text { Private } \\
\text { Private } \\
\text { Private } \\
\text { Private } \\
\text { Corporal } \\
\text { Private } \\
\text { Private } \\
\text { Private } \\
\text { Private } \\
\text { Private } \\
\text { Private } \\
\text { Private } \\
\text { Private } \\
\text { Private } \\
\text { Private } \\
\text { Private/Artificer } \\
\text { Private/Musician } \\
\text { Private } \\
\text { Private/Sergeant } \\
\text { Private } \\
\text { Private }\end{array}$ \\
\hline
\end{tabular}

List compiled from the records of the $13^{\text {th }}$ U.S. Colored Heavy Artillery on the Civil War Soldiers and Sailors System of the National Park Service. See www.civilwar.nps.gov/cwss/

* Duplicate names on the list may indicate individuals with the same name or a misspelled or repeated name. 


\section{APPENDIX II}

Clifford's nomination for J. Nelson Wisner as a candidate for United States Congress at the Republican State Convention held in Parkersburg on July 30, 1884

"Mr. Chairman and Gentlemen of the Convention:

On the $14^{\text {th }}$ of April, 1865, the night of Lincoln's assignation, the county of Berkeley and the town of Martinsburg welcomed and adopted a stranger, of whom they have ever since been proud. He found the town illuminated over the surrender of Gen. Lee, and being invited upon the rostrum made his maiden speech, well seasoned with youthful ambition, loyal patriotism, and an abundance of common sense. Recognizing cultured talent, frankness of expression, boldness to defend it, fidelity to man and fealty to the Union, Berkeley clung to him with more than fraternal affection. Under his management and tillage she has never suffered from a political famine, and if you recognize his ability and worth, a proof of which will be to nominate him, I vouch for a glorious harvest in October and a complete threshing of it in November. By him more than any living man to my knowledge, the principles of our party, which in purity rank next to heaven's, have been held sacred in Berkeley county. He is the man, who at the polls in 1866, when it was dangerous, by his own manhood and Herculean strength, maintained equal political rights, and who, during our most exciting elections, time and again, with surging masses of exasperated opponents all around him, kept them at bay, and not only made Republicanism honorable, but prevented it from being trampled in the dust, in consequence of which his former foes are his present friends. In the court-house, without a superior, battling for human rights, regardless of color or poverty; and on the rostrum in defense of republican principles, his rhetoric has been a sweeping tornado and his logic like fire! Philosophically he is the Socrates of Berkeley. 
Politically and intellectually he is the Webster of the Eastern Panhandle-around whom the loyal sons of Ham will rally as they would to no other man in this Congressional District. As the gathering of bees is a test of sweetness, so is Negro devotion to a white man a test of his unswerving manhood; and, like the $54^{\text {th }}$ Massachusetts, in the name of God and the Union, we will follow our Shaw, of Berkeley, through thick and thin; yea, surmount the enemy's fort, and there, if he falls within, we will be found lying around and covering him with bleeding bodies, as did the heroic blacks that of Colonel Shaw at the battle of Oulesee. Under the existing circumstances, over which you have but little control—and I know whereof I speak—this convention would do nothing wiser, if it wishes its candidate to succeed, than to nominate the man whom I shall soon name, to represent us in the next Congress of the United States. He is your Leonidas with whom you can cut your way through the foe's Thermopylae. Like James G. Blaine, of Maine, he has that rare power of attraction which draws men to him, and best of all, it is tinged with no deception, for he is as true to his friends as Jonathan was to David. I fearlessly challenge any man within the sound of my voice, yea, who claims West Virginia as his home, to say that he has not been true to the principles of the Republican party and the men representing them. Ask your Goff, your Hoke, your Sturgiss, your Mason and others and they cannot say a better Republican lives. That he has his envious opposers, whose weapons lie rusty and broken at his feet, is evident;--show me a progressive man void of them, and I will show you an angel. But I sincerely thank God with my whole heart, that like King David, of old, he lives to see them fall on the right and left, and is human enough to write upon their crumbling tombstones sympathetic epitaphs. Accept him, gentleman, and every valley will be traversed and every mountain crossed in search of votes. Napoleon like, if the way be merely possible, he'll cross the Alps and march to a glorious victory. Accept him, and you will be sure of every colored vote, without which, you 
cannot succeed. With these remarks, I have, and esteem it a great honor, to present to this convention, my people's favorite, and the poor man's unflinching friend, J. Nelson Wisner, of Martinsburg, Berkeley county, W.Va.”

J.R. Clifford, Martinsburg Independent, 8 February 1884, 2. 


\section{APPENDIX III}

\section{Editorial: "Independent in Politics"}

The time was, when we thought it impossible to be independent in politics, but 'wise men change, fools never!' Now, we not only consider it wise in the extreme, but consider its increasing strength, indicative of honesty, good sense, and will be the salvation of this government. Hereafter, so long as we live in the State of West Virginia, so long will we be the slave of no political party. When a boy, we enlisted to fight for this Union and the freedom of the slaves; and for the past sixteen years, we have spent our time and means, to advance the interests of a party in this State, that has showed no respect whatever for the Negro, more than to get his vote. The only honors given colored men in this State have been conventional, and most of them of an alternate character. To the Irishman, the German and the Jew courtesies are shown and to the Negro, demands are made. A few disappointed office-seekers may step down and out of a party and then, for a purpose, threaten its destruction, dictate nominations, even a Governor, and this Simon-pure Republican party buries its principles and goes over to them; or in other words, 'The tail wags the dog.' When, and before, nominations are to be made, the Greenback party, the Prohibition party and the Knights of Labor are consulted, committee and conventional honors given and nominations agreed upon to suit all factions. But just let colored men dare intimate a dissatisfaction, and they are at once told that the party can get along without them, i.e. you are their political slaves and are afraid to risk your chances in any other party. There is no party in existence that can do less, but some, we believe, will do more. However, this much is true; so long as you scrape and bow at the shrine of one party, and swear by Him that ruleth that you will remain therein, in spite of insults and moonlight promises, so long will you be treated as you have been. You are the balance of power in this State and you are fools if you don't use it in the 
Robt. W. Simmons, Geo. T. Jones, and other able men organized a 'State Executive Committee’ I was antagonistic to it. I now see its wisdom. Let us revive it and show to the world that we are men. When you talk independently to them they tell you they freed you. It is false. The persons to whom we allude, if they were soldiers, belong to that class who threw down their arms when you enlisted and marched to the front to battle for this Union and your freedom; and had it not been for you, it would have been shattered and the shackles still on your hands. Your bayonets and bullets brought about your freedom, and for it, you are obligated to no party, as much as you are to yourselves. Then let us with as much manliness protect it with the ballot. The Democratic party has done little or nothing for you until within the last two years. They claim they have not had, what they ask for, an opportunity. We do not ask the colored men of this State to be democrats—but we do ask them to be independent men—a thing impossible by cursing all other parties and sticking to a party that curses you.”

J.R. Clifford. “Independent in Politics,” Pioneer Press, September 1886, 2. 


\section{APPENDIX IV}

KNOWN NATIONAL ASSOCIATES

Knights of Wise Men:

William J. Simmons, Ky.

Frances L. Cardozo, D.C.

Bishop Henry McNeal Turner, Ga.

Richard Gleaves, S.C.

John R. Lynch, Miss.

Robert Peel Brooks, Va.

J.C. Corbin, Ark.

American Negro Academy:

Alexander Crummell, Minister

Lawrence Dunbar, Poet

W.E.B. DuBois, Sociologist

W.S. Scarborough, Greek Scholar

Kelly Miller, Mathematician

Francis J. Grimke, Theologian

Archibald H. Grimke

John W. Cromwell, Historian

R.R. Wright, Bishop, Professor

Professor Love, Educator

Professor Walter B. Hayson, Educator

G. C. Cook, Professor

J. Albert Johnson, Bishop

S.G. Atkins, Principle of Slater Normal School, N.C.

L.B. Moore, Professor at Howard University, D.C.

W.H. Crogman, President of Clark University, Ga.

J.K. Moorland

Anna Julia Cooper, the only woman ever elected to the Academy

Edward C. Williams, Principal of M. Street High School

L.Z. Johnson, Professor at Howard University, D.C.

Wendell P. Dabney, Editor and Bibliophile

Henry P. Slaughter, Bibliophile

Monroe N. Work, Tuskegee Institute, Ala.

Faduma Orishatukeh, Writer and Lecturer from Sierra Leone

Arthur A. Schomburg, Book Collector and Antiquarian

John E. Bruce, Bibliophile

Carter G. Woodson, Founder of the Association for the Study of Negro Life and History

George W. Cook, Professor at Howard University, D.C.

J.E. Kwegyir-Aggrey, Professor at Livingston College

Theophilus G. Steward 
Niagara Movement:

F.H. Murray,

Dr. O.M. Waller, N.Y.

Rev. G.R. Waller, Md.

W.D. Johnson, Mass.

Dr. C.E. Bentley, Ill.

W.E.B. DuBois, Ga.

Rev. Byron Gunner, R.I.

G.W. Mitchell, Penn.

Clement G. Morgan, Mass.

L.M. Hershaw, D.C.

T.M. Dent, D.C.

Lt. J.C. Andrews, Mass.

Rev. O.L. Mitchell, D.C.

Rev. G.F. Miller, N.Y.

Chas. A. King, Mass.

Prof. M.A. Hawkins, Md.

Prof. John Hope, Ga.

F.L. McGhee, Minn.

J. Max Barber, Ga.

Capt. H.A. Thompson, N.Y.

W.J. Carter, Penn.

W. Monroe Trotter, Mass.

G.W. Crawford, Conn.

Dr. H.E. Young, Md.

Rev. J. Milton Waldron, Fl.

Rev. G.F. Bragg, Md.

Rev. W. Bishop Johnson, D.C.

Rev. S.E. Griggs, Tenn.

Rev. J.T. Brown, D.C.

Rev. R.C. Ransom, Mass.

F.S. Monroe, Mass.

Dr. H.L. Bailey, D.C.

W.A. Hawkins, Md.

Prof. J.W. Barco, Va.

Rev. Robert W. Goff, Va.

J.B. Watson, Ga.

Prof. C.L. Davis, Md.

A.S. Gray, D.C.

Prof. W.A. Rogers, Va.

T.A. Johnson, D.C.

Prof. H.T. Pratt, Md.

John Hurst, Md.

Rev. H.C. Garner, D.C.

J.C. Stewart, D.C. 
National Independent Political League:

William Monroe Trotter, Mass.

S.L. Corrothers, D.C.

William D. Johnson, Mass.

Napoleon B. Marshall, D.C.

Bishop J.W. Alstork, Ala.

W.L. Hayes, W.Va.

Fred Harris, Ark.

J.M. Ellis, W.Va.

Paul M. Nash, Calif.

Col. George G. Ross, Col.

Matthew T. Whittico, W.Va

W.F.S. Cook, Md.

T. Edward Hill, W.Va.

Francis H. Warren, Mich. Edward P. Oliver, R.I.

Walter Gay, Conn.

Dr. J.B. Stubbs, Del. J.A. McAuley, Tex.

J.T.C. Newsom, D.C.

Col. Chas. L. Mitchell, Tex.

W.S. Taylor, Va.

S.H. Hart, Fl.

Judge Mifflin W. Gibbs, D.C.

Bishop H.M. Turner, Ga.

Dr. C.E. Bentley, Ill.

George L. Knox, Ind.

Rev. J.C. Reid, Iowa

L.G. Jordan, Ky.

Capt. W.T. Grant, La.

E.T. Morris, Mass.

Rev. G.R. Waller, Md.

Fred L. McGhee, Minn.

E. Marshall, Mich.

Dr. S.D. Redmond, Miss.

George E. Stevens, Mo.

H.J. Pinkett, Neb.

J.F. Slaughter, N.H.

William T. Ferguson, N.Y.

J.L. Johnson, Ohio

Rev. J.E. Churchman, N.J.

W.E.B. DuBois, N.Y.

G. C. Clements, N.C.

A.C. Alford, Ohio

M. Twine, Okla.

William H. Harris, D.C.

M. Canady, Oregon

Rev. E.W. Moore, Pa.

Dr. J.H. Wiley, R.I.

Names compiled from numerous resources and includes those before and after the NIPL split in 1913. 


\section{APPENDIX V}

\section{ADDRESS TO THE COUNTRY OF THE NATIONAL NEGRO-AMERICAN POLITICAL LEAGUE OF THE UNITED STATES}

The National Negro-American Political League of the United States in Congress Assembled sends Greetings to their fellow citizens throughout the nation.

As a people we are facing a serious political crisis, and it is time for us to be alert to resist injury and to grasp advantages. Our civil and political rights, contrary to the fundamental law of the nation, have been ruthlessly taken from us in the South land. A new slavery has arisen in that section in the form of peonage, which is almost as vicious as the old slavery. The army record of our soldiers, unsullied for a hundred years, and of which every Negro is proud has been disregarded and 167 brave soldiers have been arbitrarily dismissed for the service without honor and without trial.

As citizens of the Republic we come back again to Philadelphia, the Cradle of Liberty, to try to generate a sentiment that will clasp into unity the scattered forces of the Nation that are trying to beat back the rising tide of contempt for the Constitution. We come to issue another Declaration of Independence. The spirit which brings us together here in the City of Philadelphia in 1908 is the same spirit which brought the signers of the Declaration of Independence here in 1776. If taxation without representation was unjust in the days of Patrick Henry, George Washington, and Thomas Jefferson, taxation without representation is unjust now. If it was wrong to condemn and punish men without trial then, it is wrong now. If it was true in those days that all men were born free and essentially equal in human attributes and possibilities, it is true now. Class distinctions are just as invidious now as they were when brave little American struck for her freedom. Tyranny has not lost one iota of its hatefulness and men will still sacrifice their property, their honor, their lives, their all, that the cause of liberty might live and that their children might be free.

We are fighting laws and executive rulings that discriminate against a man because of his race or color. We are fighting the sentiment that apologizes for or justifies such laws and rulings. We ought to be able to count on every Negro leader with a spark of self-assertion in him America for support. We are in the midst of a perilous crisis and the Negro who does not come forward and call for justice for his people at this time is a soulless, unimaginative creature whom no crisis would arouse and no duty inspire.

We have had enough of the dreary drip of doleful declamation about the Republican party freeing us. We have long ago paid them with interest the debt we owed them. We have come to the years of manhood as a people. Hereafter let it be understood we will support the Republican party when it puts up fit candidates. We will not support any man who justifies or apologizes for Southern disfranchisement. It is right that we use our ballot as weapon of protection. The deeper the researches of history are pushed, the more irresistibly emerges the broad conclusion that the world respects a man or a race that cannot be imposed upon with impunity. He who scrapes and kowtows to please his unreasonable neighbors will forever be regarded by his neighbors as the lackey and the lick-spittle that he is.

Some say that if we do our duty our rights will come to us. A lie with less justification in history was never told. In a Republic rights are not ornamental, not unnecessary, not subsidiary in the march of progress. We must have our rights before we can as citizens do our duty. In America self-respect is sustained by being kept on a plane civilly and politically with all other 
citizens.

Secretary Taft sees a turn for the better in our Southern disfranchisement laws. He has justified President Roosevelt's rash outrage in discharging our soldiers without honor and without trial. Our Southern disfranchisement laws are bad-all of them. There is no one single praiseworthy section in any of them. They disfranchise 95\% of the colored race in the South regardless of qualifications. They are all pernicious in principle and mischievous in operation and ought to be condemned without mercy or quibble. To make stealing legal does not make stealing moral as Mr. Taft seems to think, and the man hasn't sound national ideas who looks and thinks in this way. For these reasons we cannot support President Roosevelt or Secretary Taft if either one gets the nomination; for we see little difference between a democratic nominee and a republican nominee of an administration in open alliance with our enemies.

We heartily endorse the candidacy of Senator Joseph Benson Foraker for the presidency. He is a brave, true-hearted American citizen whom the American people would do well to honor by making him their chief executive. He is the Negro's friend and he is the man best suited to conceive and execute a policy to preserve our free institutions. If Senator Foraker quits the race, which we hope will not happen, we will support any other genuine Republican who has not shown himself inimical to tour rights.

We demand that our soldiers be reinstated in the army and restored to their ranks without prejudice and without loss. To the end of the chapter we are going to fight the men who are responsible for their discharge. We want Congress to pass the Foraker Soldier Bill. We want the electoral tyranny of the white south dragged from its palsied hands. We will fight any body who apologizes for or justifies Southern disfranchisement.

We want to smash Jim Crow Cars. If we cannot smash them, we will undertake to smash the party which being in power, tolerates them.

We want the Negro boss-shop which deprecates progressive movements among Negroes overturned; and we are against any administration that encourages and gives influence to sycophancy in order to crush our self-assertion in the Negro Race.

We want to see a strong Republican Party built up in the South, but we are unalterably opposed to Lily-whiteism as a means to that end. The men who have been stalwart and loyal republicans for a half century at great risk and sacrifice ought not to be brushed aside to encourage the Lily-white movement. We protest the seating of delegates in the national republican convention elected by conventions which drew the color line.

We demand that peonage be wiped out in the South. We beg to call the attention of a Republican Congress to the fact that the black man in the South is a peon as well as the foreigner and we feel that we area at least entitled to as much consideration as the man who has only recently come to our shores.

We oppose the policy of a president dictating his successor in office, and the domination of the judicial and legislative branches of the government by the Executive.

We must insist that no alliance be made in this campaign save an alliance of freedom and equality and no peace that does not rest on the safe and permanent basis of equal and exact justice between man and man. We want all that belongs to full-fledged American citizens. We are in earnest. We cannot be bulldozed. We cannot be bought off. And under God, we will be heard!

Signed by the committee on Address to the Country, Bishop A. Walter, New York; S.L. Corrothers, District of Columbia; J. Max Barber, Illinois; Rev. W. Gay, Connecticut; J.D. Bonner, New Jersey; Gurley Brewer, Indiana; Rev. R.S. Rives, Kentucky; Rev. G.R. Walter, Maryland; W.M. Trotter, Massachusetts; J.R. Clifford, West 
Virginia; J. Churchman, New Jersey; Hon. Geo. H. White, Philadelphia; Rev. W. Buydden, Ohio; G.H. Woodson, Iowa; Bishop Alstork, Alabama; Rev. L.L. Marshall, Virginia; Dr. Howard E. Young, Maryland.

ADOPTED AT PHILADELPHIA, PA., APRIL 8 ${ }^{\mathrm{TH}}, 1908$. 


\title{
APPENDIX VI
}

\author{
Annual Address of National Independent Political League
}

Faneuil Hall, Boston, Mass., August 31, 1911

Ladies and Gentlemen:

"It is altogether proper and fitting that we meet in this old historic hall, wherein God's chosen sons of men made the old lion of slavery that is now toothless, rise, rouse and wrestle his mane! Faneuil Hall is sacred to me, as is John Brown's Fort and the room wherein the Guardian is published. Believing in the reappearance of departed souls, that worked so hard and suffered so much for what we are only partially enjoying and contending for, how natural to feel that the real Garrison, Phillips, Lincoln, Douglass, John Brown, Lovejoy, Harriet Beecher Stowe, Julia Ward Howe, and thousands of others are here tonight, aiding and abetting us in our work for manhood rights. I go further and say, that those who lived and died for our freedom, are doing our cause more good at the eternal bar of justice than they could were they here, hence how vastly important it is, that we fit ourselves to receive our just and equal rights.

Within this God-blessed and hallowed place, December 1885, John Boyle O’Reilly, in that memorable address of his, before his colored fellow citizens, said: "If I were a colored man, I should use parties as I would a club, to break down prejudice against my people. I should not talk about being true to any party except so far as that party was true to me. Parties care nothing for you, only to use you. You should use parties. The highest party you have in this country, is your own manhood." How true! And to help make it better, is our mission here in Boston, in the year of our Lord, 1911.

True it is, that education is great, but manhood is greater. The one is principle, the other is accident. Man was not made as an attribute to education, but education as an attribute to man. 
First protect the man, and you will, therefore, protect education. I would not make illiteracy a bar to the ballot, but would make the ballot a bar to illiteracy. Take the ballot from the Negro, and you take from him the means and motive that make for education. Under the constitution, every right the white man enjoys is yours, and if you have the right kind of manhood you will not surrender a particle of it, for whatever is a man's own, absolutely is his own. No man has a right to take it without his consent. He who attempts it, attempts an injury; he who commits it, commits a robbery.

Are you going to boast of freedom and allow it to be done?

Forbid! Almighty God. I grant the fact that our worst foes are among our own people, and that they are as dangerous to our solid progress, as are poisonous snakes to humanity. Oh! That we had the right to have the same confidence in every living Negro that Washington had in his soldiers at the battle of Trenton, when he said: "None but Americans on guard tonight."

It is our absolute duty to learn to agree to differ and work for unity in essentials, liberty in non-essentials, and in all things charity. For the constitution of the United States, built on and after the spirit of the religion of Jesus Christ, calls for equal opportunities for every man and that means civic and political, along with work, education, culture, and everything else that goes to make a full man. This division of the human, or one blood family, called Negro, will not as a mass, contend for these rights-too much servility in their blood. That must be done by individuals, who, like Latimer and Ridley, by God's grace are kindling a fire that will never go out. There never has been an age that called for stronger men and women to do battle against more hellish wrongs than are raging in this-our country. The greatness of America and all other countries cannot be traced to the noble conduct of the masses, but to the few educated men and women imbued with independent thought_-men who after reaching conclusions, rather than 
recant, like John Brown, would die in their defense-exactly what we need and must haveUpright, virtuous, truthful men—masters of science and unflinching workers, and all else will follow.

God and nature speak to manhood, and in the language of scripture we are asked to quit ourselves like men. In all of my contention for the rights of the oppressed, I have said more of and about manhood than of race or color. The battle for liberty was not won because of race of color of the Negro, but because and only because, he is a man of the one blood family. There is no refinement, moral or intellectual quality in the color of a man's cuticle, it is neither good nor bad. It is nonsense that a man must be black to be true to the rights of black men. Our best friends have been white men, and the United States has enough of such to unite with us in the completion of the work in which we are engaged. I claim it is better to regard ourselves as a part of a whole, than the whole of a part. Did I hear some one say, but we are so bitterly persecuted. I know it. I admit it. I deplore it. I denounce it.

They are trying to discourage us; destroy the amendments; rob us of our franchise; make us ride in filthy Jim-crow cars; ostracize us in their churches; deny us hotel and restaurant privileges; nevertheless and notwithstanding it all, I see plainly in it the most convincing evidences at our unprecedented progress and the certainty of a brighter future.

The slave never had opposition, nor does the menial or servant. It is aimed at the Negro gentleman, the business man and our scholarly and refined men and women. The Negro is all right long as he goes in rags and ignorance, for then he is in his place.

A ship at anchor, with balliards [bollards] broken, sails mildewed, hull empty, her bottom covered with sea weeds and barnacles, meets no resistance. She lies perfectly still. But when she spreads her canvas to the breeze and sets out on her voyage, turns prow to the open sea, the 
higher her speed, the greater her resistance. And so it is with the colored man. He meets with resistance now more than ever, because he is fitting himself for higher life. He is shedding the old rags of slavery and putting on the apparel of freedom. Plight with God for courageous manhood, and like the mariner who, amid hail, rain and storm bolts, battles his way against all that the sea opposes to his progress, and you will reach the goal of your noble ambition.

And be assured my fellow citizens that the perpetuity and prosperity of a government like ours, depend entirely upon virtue, intelligence, and patriotism of its people, for they are the source, the fountain from which his a life and power emanate. Every citizen of our republic is a sovereign whose creed, religious and political, are absolute and unquestioned under our constitution, the great Magna Carta, upon which our institutions are founded. Our government is a government of the people and for the people.

It is easy then to realize that upon every citizen rests an individual responsibility-a duty from which there is no exemption for any cause whatever. Every individual, so to speak, is a pillar of support; hence any failure to perform his duty promptly, intelligently and patriotically may develop a weakness in the structure which will subject it to the awful dangers of revolution and subversion.

The measure of the progress of civilization is the advance of personal liberty. Destroy personal liberty, and you chain civilization to its dead body, where it will remain prostrate and helpless, until the devastating influence of national sin and neglect, like a cancer, have eaten out its life and built upon its ruins, the throne of despotism and degradation. Thus we see that the life giving elements of our institutions are virtue, intelligence and patriotism. In these and in these alone, is found the source of our existence as a people. They must, therefore, be guarded with jealous care, if we would down the old Greek and Roman idea of class freedom. Their 
government was not by the people and for the people, but the people were for the government, and what became of them? Then certain it is, that the safety of this republic, the perpetuity of its glory and the stability of its institutions are commensurate and only commensurate by the practice of the golden rule and the parable of the good Samaritan. But you must keep in mind that the golden rule of politics needs to be followed to the letter thusly as John Minor Butts advises. "Whatsoever thy political enemy would do against you, do you even the same to him," which means an eye for and eye and a tooth for a tooth and that for your welfare, honest conviction should always be put above party alliances and its lash.

Bishop Turner declares he has no country and calls the flag "a dirty rag." They are both mine. Yea, this beautiful continent is ours, state on state and territory on territory to the waves of the bounding seas. There isn't an element in land and water, but what is in you and me, hence we are part and parcel of it. And if I had my way, every colored boy and girl in America should be made to commit the Constitution of the United States thoroughly, before another meal should be eaten. It's a splendid foundation on which to build our education and manhood.

Don't be alarmed about the prediction of Dr. Earnest C. Levy, Chief Health Officer of Richmond, Virginia, who tells the world that the colored people are rapidly dying off and will be extinct in the $21^{\text {st }}$ century. No doubt the wish is father to the thought. Segregated, chain-ganged, worked and robbed, and forced to live in town and city hubs and hovels located in filthy alleys and back streets, what would have been the outcome of the whites under similar conditions? But here is where the alarm comes in-they have in the face of it all run up from four to ten million since the war. Did they die in Cuba? The Philippines, or in America in slavery? No. But they have been nurses for centuries for the sick whites and nursed the fever-stricken white soldiers in Cuba-themselves immune to the disease. 
The reason given for forcing Negroes in filthy places to live, is that they are a menace to decency. Were they a menace to the whites when slaves? They are all there was that was good and bad of slavery, and their accusation of us is their own condemnation. Under favorable circumstances the Negroes are the healthiest and most virile people on earth, and debauched as they have been by slavery that knew no marriage, allowed no learning, no liberty, no rights and no respect for virtue how can it be otherwise than the whites must father our sins. It is truly white men's and not a Negro problem. Jefferson foresaw all this and said he trembled for his country. And one time when the Greeks were being murdered by the wholesale, a white woman who owned slaves, wrung her hands and said: “O Mr. Jefferson, those poor Greeks, those poor Greeks, how can we help them?" Pointing to her slaves, Jefferson said, “Madam, the Greeks are at your own door, and they will remain there till God rights that wrong, if He has to decree another war to do it. When Fred Douglass said: "The only problem in America is, whether or not, the white man has enough of the religion of Jesus Christ to treat the black man as a brother," he said it all.

Sometime ago a Catholic priest riding by a man plowing, stopped and said: "Brother if you were sure you would die tonight, what would you do the rest of the day?" The man replied, "Plow!" So I say to you to keep on plowing for all the rights guaranteed to you by the Constitution of the United States. Rights vouched safe to you by 449 bloody battles fought by nearly 200,000 brave blacks who donned the blue and barred their breasts for your freedom and the union of the country. The battles they fought at Fort Pillow, Petersburg, Richmond and Nashville, excelled for bravery the famous battle that Leonidas with his 300 brave Spartans fought at Thermopylae.

And we not only gave the Union cause the power to rush out rebellion, but have kept it in power ever since, and now are being paid back in damns for our devotion. And as that color 
bearer said: "Colonel I'll return those flags to in honor, or I'll report to God," the reason why, so do I say to you, and you must say to others-brothers, we must stand shoulder to shoulder in this political struggle for equal rights and liberty, or go down to our graves worse slaves than we were before the war.

If you believe the voice of the oppressed is heard at a tribunal were no quibbles over constitutional trammels are accepted in abatement of justice, then, you must believe that the blood that smokes on Southern soil will rise up in future punishment against you for your cowardice and negligence with almost as much condemnations as the robbers of our rights, and the lynchers of our people will get.

To limbo with educating Negroes for servants-the advocated sophistry of Booker T. Washington, who has done our cause more harm than all the Negroes in America. The teeth of time are busy and it won't be long till a central bonfire can be lighted.

While I have no sympathy whatever with those who affect to despise labor, even the humblest form of it, and hold whatever is needed to be done, it is honorable to do, it is nevertheless plain that no people, white or black, can, in any country, continue long respected, who are confined exclusively to mere menial service for which but little intelligence or skill are required, and for which the smallest wages are paid or received, especially if the laborer does not make an effort to rise above that condition. While the employment as waiters at hotels and on steamboats and railroads, is perfectly proper and entirely honorable, in the circumstances which now surround the colored people, no variety of the American people can afford to be known only as waiters and domestic servants.

While I say this, I fully believe in the dignity of all needful labor. All honest effort to better human conditions is entitled to respect. 
Daniel Webster used to say that New Hampshire was a good state to emigrate from. So I say of menial service. It is a good condition to separate from just as soon as one can find any other calling which is more remunerative and more elevating in its tendency. It is not the labor that degrades, but the want of spirit to rise above it.

Exclusive service or exclusive mastery is not good for the moral or mental health of any class. Pride and insolence will certainly be developed in the one class, and weakness and servility in the other. The colored people, to be repeated, must furnish their due proportion to each class. They must not be all masters or all servants. They must command as well as be commanded.

When a boy I was a farmer, then a waiter, next a barber, then a teacher, next an editor and last a lawyer and the first to be admitted to practice in my state. I used them all as a means to the final end. My philosophy of work is, that a man is worked upon by that which he works. Some work requires more muscle than it does mind. That work which requires most thought, skill and ingenuity, will receive the highest commendation, and will otherwise do most for the worker.

Things which can be done simply with the exertion of the muscle, and with little or no exertion of the intellect, will develop the muscle, but dwarf the mind.

Long ago it was asked "How can he get wisdom who holdest the plow, and whose talk is of oxen?" There is no useful thing that a man can do, that cannot be better done by an educated man than by an uneducated man.

In the old slave days the colored people were expected to work without thinking. They were commanded to do as they were told. They were to be hands; only hands, not heads. Thought was the prerogative of the master. Obedience was the duty of the slave, and the same 
tables are trying to be turned on us politically, but in the language of Robert Burns, I say,

“Were I designed your lordling’s slave,

By Nature's law designed,

Why was an independent thought

Ever planted in my mind?”

I declare in the language of Shakespeare: "What a piece of work is man! How noble in reason! How infinite in faculties! In inspiration, how like a god; the beauty of the world; the paragon of animals.”

How foreign to Bookerism! Man's true dignity is not to be found in his muscles, but in his head. That is the seat and source of all that is great in him.

There is fire in the flint and steel, but friction is required to make it flash, flame and burn, and give light where all else may be darkness. There is music in the violin, but the touch of the master is needed to bring it out, fill and thrill the soul.

So the latent manhood in the Negroes can only be rounded out by the same means and process that has made the white masters in letters, skilled in labor, science and mechanism.

Our watch word is, "Equal Rights and opportunities for all American citizens." We are being asked on every hand why this organization exists. What caused the war of the rebellion? Your correct answer ought to be-chattel slavery. Political slavery, worse from many viewpoints, is the cause of our organization. Many may not see things as we do, by the ones who are condemning us now. "We stand for men and measures, rather than for parties." What do you stand for? We believe_-"In a Republic the citizen's most effective weapon is his ballot." Do you believe this to be true? If so, how can you blame our efforts to put the ballot in the hands 
of millions of your disfranchised brothers?

So long as our kinsmen are lynched by more than half a hundred at a time; tens of thousands being worked to death on chain gangs and in prison-pens called peonage, and millions politically enslaved, so long will there be work for "The National Independent Political League to do.

Shall we rise from injury to arms, and from arms to liberty, and then be too cowardly to contend for it? No! and no! again. Who allowed these wrongs to be inflicted upon us, but the party who has been kept in power since the war? Yes, the party who pledged honor and the full fruition of additional constitutional amendments, now trampled under foot by confederate granddaddy clause? Who pardoned those peonage murderers of our people lives and liberty but President Taft? Who put every Negro office holder in the South out of office to please the Negro hating South? Answer. William Howard Taft.

Who was it that told the President of Fisk University that the colored people are a distinct class and must be so treated? Your republican President—dubbed by the south, "Billy Possum." Who was it that ordered the discharge of our soldiers at Brownsville? Mr. Taft.

When sixty odd innocent Negroes were butchered like hogs in Texas, July 1910, show me a word of condemnation from your republican President-I am frank to say, I am too "distinct" to own him. We believe that no acting head has ever companioned a human heart, that there was not a ray of glory ready to fall on it, and like Bishop Taylor, who declared that he would rather spend his next twenty years with the savages of Africa than with the angels in heaven, so would we prefer to spend our next fifty years trying to enlighten and Christianize the white savages of America, than spend that time in heaven. In the name of justice, I ask why not cooperate whole heartedly with us? We are willing to be courteous to all, but slaves to none. Mr. Taft's advice to 
us how to be friendly with the South recalls to me, Theodore Roosevelt's advice to the English people how to treat their colored subjects in Egypt. Did he not dine and wine Southern lynchers at the White House?

It was he who discharged and disgraced the very soldiers who saved his life in Cuba and divided their hard tack with him. It was he who if not directly, did by innuendos, brand us as a rape race, when the following year five fathers of his color raped their own daughters. Looking back over the history of slavery, when his color groomed stalwart Negro men from plantation to plantation with robust women for the purpose of similar beings for sale, his lips should blister in shame. If the Negroes constitute a rape race, why was the crime never charged to them during the war when they stayed with the white women at home during slavery, worked and cared for them? If we are a rape race, why is it that all of the thousands of white northern lady teachers who went South and remained there and among them as teachers for years, the charge of rape was never made? We are not a rape race. True we have some black scoundrels among us, and the wonder is, that all are not so.

But where you find one of that kind you'll find fifty thousand who would give their lives in defense of the purity of womanhood. All that the Negro is in rascality, lascivity and everything mean and low, Mr. Roosevelt's color taught him. For twenty-five years, through the Pioneer Press, I have been urging the speedy use of the surgeon's knife for all such human beasts-white and black; and by our politically clannish conduct for this class of republicans, we have won the hatred of one and the contempt of the other. We are going to redeem ourselves, for no man ever put an honest heart into an honest cause with push and pluck and failed. It's possible to gather fully half million voters around our standard by this time next year. In devotion to your people be like the Irish, the Italians, Jews and Japanese. The Irish send back to Ireland nearly \$3,000,000, 
the Chinese \$4,000,000, and the time will come, when American Negroes will be as loyal, I know it. I feel it. I see it. In hope of this we here pledge our lives and honor to work for it till the honest and blackest of God's children catch the inspiration. Charles H. Parkhurst says"Prejudice is skin against soul, and pigment depriving a man of an heirship from heaven, and we are united to drive it to hell and ourselves to heaven."

No finite mind could know that a fire-cracker would cause Portland to burn; that a cow kicking over a lantern would set Chicago on fire, or that mice playing with matches would burn Boston. Equally true is it, that no man's prediction that the Negro's hopes are blighted should have credence. He is the child of God, and possibly his most favored, because of his presentor's prostration of his manhood and defamation of his character, for "Blessed are ye when men shall revile you, and persecute you, and shall say all manner of evil against you falsely for my sake, rejoice, and be exceedingly glad, for great is your reward in heaven." God has wrought miracles for him and will continue so to do, if he loves the Lord his God with all his soul, mind and strength, and his neighbor as himself. It was his service to God before and during the war that made Mr. Tooms say to Jeff Davis— “Our cause is lost.” Why? said Davis, "Because the infernal niggers pray too much and God will hear their prayers.” “They are ours,” said Mr. Davis, "make them pray for us." "Yes," said Tooms— “pray for us with their lips, and for those infernal yankees in their hearts." He was right.

As God raised up Abraham Lincoln to emancipate 4,000,000 slaves and save the Union, also Moses out of a race of slaves, and Shakespeare out of a set of sea thieves, so will He give us men and women who will astound the world. It will only happen in our extremities after having done our part, as was the case with the man who after trying to paint a picture for twenty years and failed, by dashing his brush against it to destroy it, made the very tint that he had failed to all 
that time; and also the man who had suffered so long with intense pain, and had spent a fortune to and could not be cured, decided to end his life, by plunging a knife into his side, when lo! And behold an abscess was opened, and he got well. Truly man's extremity is God's opportunity.

To better illustrate, before the San Francisco earthquake, Knob Hill was so aristocratic and caste-cursed that the people were not allowed, but the Sunday after the power of God smote it, it was tuned into a place of prayer and black and white and the poorest of men were there on bended knees praying to their one God. Do your duty and the like some day may be your glory. Though you are buried deep under prejudice, beat on the pipe of faith in prayer as did that miner a year or so ago when six-hundred feet underground and was fed by pouring milk down that pipe, so will God feed you with His bountiful supply of saving grace. Be men, work and trust the Lord and you will reach the pinnacle and view the landscape o'er.

I cling to and love the man who dares to stand alone in the right. It is one of the best ways to be popular with God; and I would rather be that, than to have the applause of the world and be popular with men. Silence, when protests are needed is a crime and makes you a coward. Will you protest? Will you, if need be, stand alone in the right? The human race has only climbed up by doing it, and so can you. If you will, I hail you as my kinsman, my clansman, and my brother beloved.

J.R. Clifford, Pioneer Press, September 2, 1911. 


\section{APPENDIX VII \\ Resolutions of the National Independent Political League, 1912}

We, the National Independent Political league, in fifth annual session assembled in this city, where the Declaration of American Independence was signed on Independence day, the one hundred and thirty-sixth anniversary of its issuance in the same city where this independent league was organized four years ago to preserve liberty and equality for colored Americans by the enforcement of the constitution, declare to our native country our fealty to tenets of the first great independence declaration and our loyalty in letter and spirit to our first declaration of independence from political party slavery sent out at our birth.

We reaffirm our position as there stated against traitor to our rights and our intention to continue our policy of opposing them with our ballots as a weapon of self defense under the motto “For Men and Measures Rather Than Party.” We continue to insist on full manhood, political rights and equal civil rights and absolute equality of opportunities in all walks of life for all Americans regardless of race or color. We will be satisfied with no compromise.

We continue to oppose color prejudice, especially as manifested in color segregation in places of public assembly, accommodation or residence. We declare un-American and infamous the Jim Crow carrier for race or color or to segregate therein.

We continue to protect against disfranchisement for race and color in the south. It is permitted by the federal government even under Republican administrations in violation of the plain intent of the fifteenth amendment. Meanwhile, the disfranchising states are given their full quota of congressmen in positive violation of the fourteenth amendment. We demand that the president and congress break up this wrong by the enforcement of the constitution.

We continue to deplore and condemn the lynching of human beings. This mob murder is 
We continue to deplore and condemn the lynching of human beings. This mob murder is anarchy and barbarism, an exhibition and publication of the weakness of government and the brutality of the people. The false excuse of assault upon white women brazenly asserted in an official measure by ex-President Theodore Roosevelt has been exploded, especially by the shameless lynching of colored women. All the boasted humanitarian interests of the American people seem impotent to even the burning alive of human beings. State courts are powerless to punish lynchers, as is notorious in the Coatsville shame here in Pennsylvania. Lynching has become a national menace and scandal, requiring national treatment.

We demand that congress make lynching a federal crime under the sole jurisdiction of the federal courts, with right to change of venue. Nothing is more cruel or productive of discontent and crime than the denial of industrial opportunity because of color, so flagrantly prevalent in this land. Especially inconsistent is exclusion for race and color the membership of labor unions, which claim the right to monopolize employment. We demand state and federal laws prohibiting the same.

We continue to demand the same schools and education for all, regardless of color, with a genuine mixing of teachers and members of school boards as of pupils.

We reiterate our appreciation of the worth and work of ex-Senator Joseph Benson Foraker as expressed in our first declaration of independence. We thank and commend such men as exSenators Foraker and Bulkeley, who went to their political deaths at the hand of President Roosevelt battling for a square deal for the colored soldiers in the Brownsville discharge without trial, the blackest crime in the annals of our army, and here declare we will not forget their destroyer. We reaffirm our position that these soldiers have not yet had justice at the hand of Theodore Roosevelt, President Taft or congress. We demand that congress pass the Foraker 
soldier bill and pledge our opposition to everyone involved in this lynching of soldiers until he reverses his position.

We declare consistency with our first declaration our opposition to those condemned therein and that until they reverse their positions they are not entitled to the votes of self respecting colored men. We commend the native people of the Philippines for their stand for the independence of their country and in conformity with our great declaration of independence urge congress to grant them that independence which our republic enjoys.

We commend the colored Cuban patriots for their manly resistance against a denial of full rights. Color prejudice has grown there by the invasion of people of the United States. We call upon congress to prevent the sending of United States warships to Cuba to interfere against these Cubans fighting for their rights and liberties. Public school education is fundamental to our republic. Inasmuch as the failure of certain states to provide adequate school facilities is well known, we demand that congress pass a law for federal aid to education along the lines of the bill of that great patriot Hon. Henry W. Blair.

We advise the colored men of this country to agitate against all injustices and to use their ballots as a weapon of self defense, as a means to secure justice, liberty and equity, by voting not for the benefit of any party, but for the benefit of their race, punishing the recipients and beneficiaries of their votes who when elected are recreant to their interests by voting them out and ever seeking by all alliances to weaken or diminish the hostility of their avowed enemies.

We desire to ally ourselves with all those who are laboring for equal rights and opportunities for all the oppressed people of the world. We recognize that we have condemned many in these declarations, but we have not done so from malice, but out of necessity and the desperate resistance to the loss of our rights. We are glad to thank Sen. W.M. Crane for his stand 
for justice for the black battalion and favorable reception of the Moody-Pillsbury anti-lynching bill and constant loyalty as senator to the colored people.

We thank the Methodist Episcopal general conference for petitioning the Republican platform committee for this anti-lynching bill and condemn the president for his appointment of Judge Pitney and non-appointment of Judge Hook on request of colored citizens. We commend also Mr. Chapin, the last presidential candidate of the National Prohibition party, for his rescue of a colored man out of the hands of a lynching mob and appeal to all friends of freedom to bring about liberty and equality for all in this land of our fathers.

“Independent League Adopts Resolutions,” Pittsburg Courier, July 26, 1912. 
"What We Like To See"

Better Times.

Work for all.

Good scholars.

Trains on time.

Sickness banished.

Enterprises encouraged.

The tariff remain as it is.

Old enemies become friends.

A lady throw a stone straight.

Order preserved on the streets.

People mind their own business.

Corn and wheat go up in prices.

The poor encouraged and assisted.

Kind parents and obedient children.

Men stop lying about cold weather.

Martinsburgers stand by one another.

The smoke of the factory curling over our city.

Sunday schools and churches better attended.

Less temper in our dealings with our fellow men.

J.R. Clifford,

Pioneer Press, November 1886. 